\title{
Aesthetic Impact of Solar Energy Systems.
}

Conceptual Framework, Social Perception, and European Projects Involvement

Núria Sánchez-Pantoja Belenguer

Directoras: Rosario Vidal Nadal M. Carmen Pastor Verchili

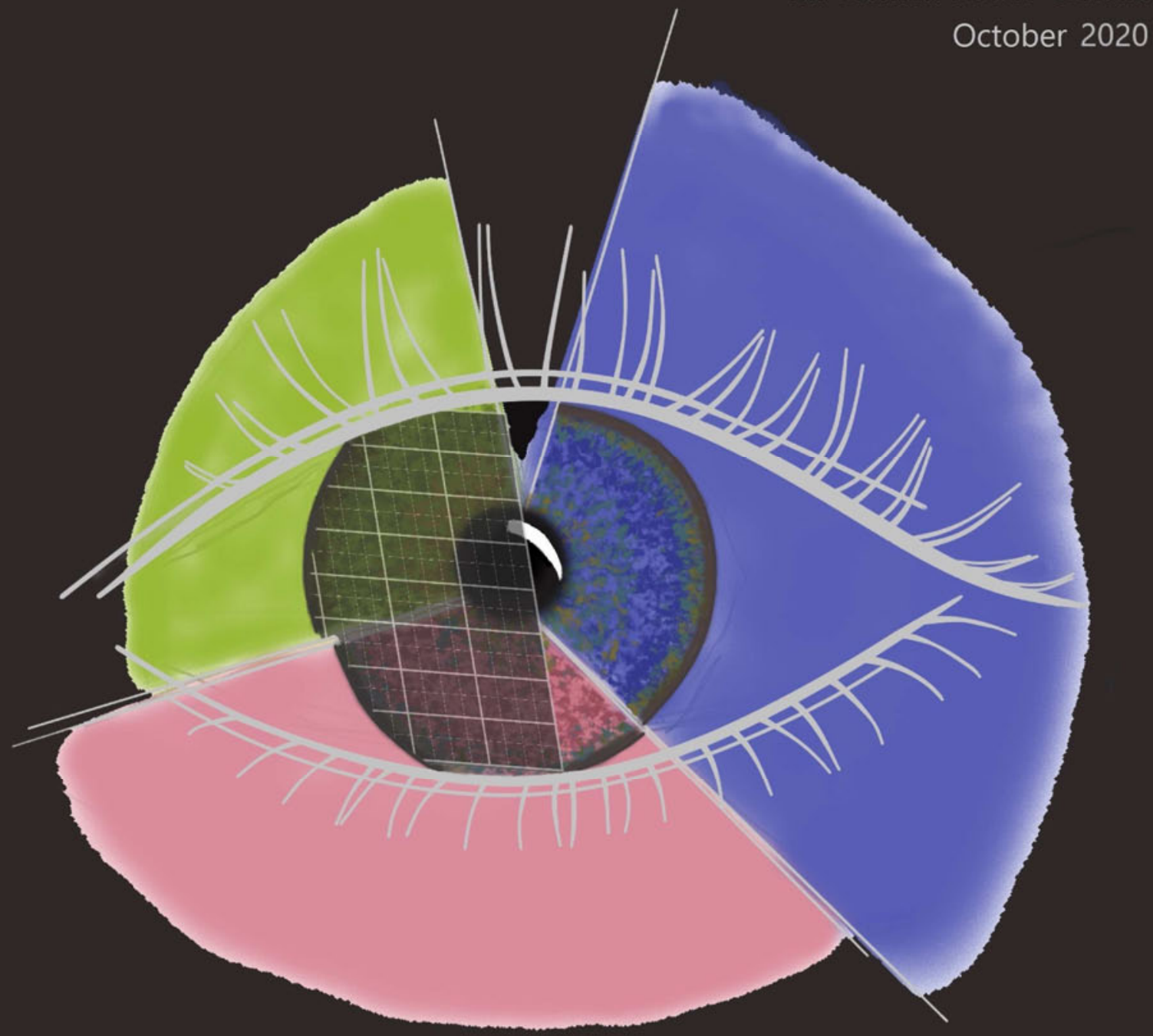

Doctoral thesis

\section{U U UIVERSITAT - JAUME $\mathbf{I}$}





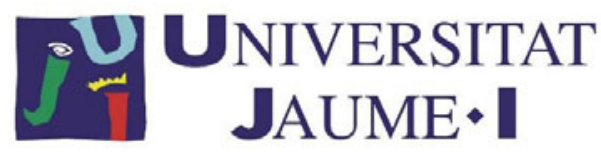

Escola de Doctorat de la Universitat Jaume I

Programa de Doctorat en Tecnologies Industrials i Materials

\section{Aesthetic Impact of Solar Energy Systems. Conceptual framework, social perception, and European projects involvement} Ph.D. Thesis

\section{Impacto Estético de los Sistemas de Energía Solar. Marco conceptual, percepción social e implicación de los proyectos europeos}

Memoria presentada por Núria Sánchez-Pantoja Belenguer para optar al grado de Doctora Internacional por la Universitat Jaume I.

Autora

Firmado digitalmente por NURIA| SANCHEZ PANTOJA|BELENGUER Fecha: 2020.10.22 10:53:56 $+02^{\prime} 00^{\prime}$

Núria Sánchez-Pantoja
Directoras
Firmado por MARIA ROSARIO VIDAL NADAL

NIF:21652812Z el día

$21 / 10 / 2020$ con un certificado

emitido por ACCVCA-120

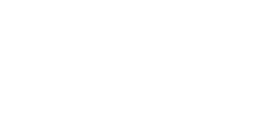
Rosario Vidal
M. Carmen Pastor 


\section{FUNDING}

The research carried out, whose result is this thesis to obtain the International Doctorate degree, includes 3 months of research stay at the University of Bremen, financed with a scholarship from the Balaguer Gonel Hermanos Foundation.

\section{FINANCIACIÓN}

La investigación llevada a cabo, cuyo resultado es esta tesis para obtener el título de Doctorado Internacional, incluye 3 meses de estancia de investigación en la Universidad de Bremen, financiada con una beca de la Fundación Balaguer Gonel Hermanos.

\section{FINANÇAMENT}

La investigació que s'ha desenvolupat i el resultat de la qual es esta tesi per a obtenir el títol de Doctorat Internacional, inclou 3 mesos d'estada d'investigació en la Universitat de Bremen, finançada amb una beca de la Fundació Balaguer Gonel Hermanos. 


\title{
Tesis por compendio de las siguientes publicaciones/Thesis by compendium of publications:
}

1. Núria Sánchez-Pantoja, Rosario Vidal, M. Carmen Pastor. Aesthetic Impact of Solar Energy Systems. Renewable and Sustainable Energy Reviews, 2018, 98, 227-238. DOI: 10.1016/j.rser.2018.09.021

Según datos del Journal Citation Report (JCR), para el año 2018, categoría "Green \& sustainable science \& technology":

\author{
Cuartil: Q1 \\ Ranking: 1/35 \\ Factor de impacto: 10,556
}

2. Núria Sánchez-Pantoja, Rosario Vidal, M. Carmen Pastor. Aesthetic Perception of Photovoltaic Integration within new Proposals for Ecological Architecture. Sustainable Cities and Society, 2018, 39, 203-214. DOI: 10.1016/J.SCS.2018.02.027

Según datos del Journal Citation Report (JCR), para el año 2018, categoría "Construction \& building technology":

\author{
Cuartil: Q1 \\ Ranking: 6/63 \\ Factor de impacto: 4,624
}

3. Núria Sánchez-Pantoja, Rosario Vidal, M. Carmen Pastor. Analysis of the Aesthetic Perception in European-funded Projects with Actual Deployment of Renewable Energies in Cities. Pending acceptance for publication in the scientist journal Energy Policy.

Según datos del Journal Citation Report (JCR), para el año 2019:

Cuartil: Q1

Ranking: 40/265

Factor de impacto: 5,042

Esta tesis dispone de la aceptación de las coautoras de las publicaciones que la doctoranda presenta como tesis y su renuncia expresa a presentarlas como parte de otra tesis doctoral.

This thesis has been accepted by the co-authors of the publications listed above that have waved the right to present them as a part of another PhD thesis. 


\section{CONTENIDO}

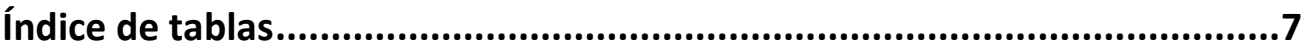

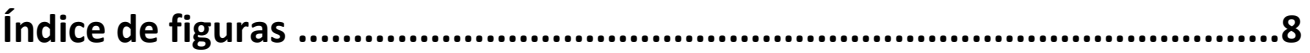

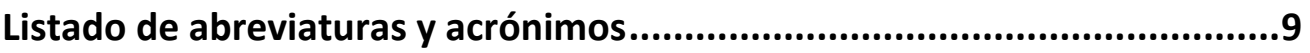

Abbreviation and acronym list ...............................................................10

Anexo: Trabajos publicados ..................................................................12

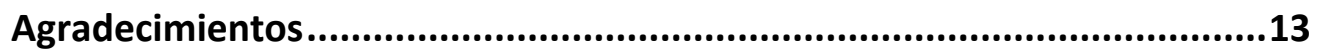

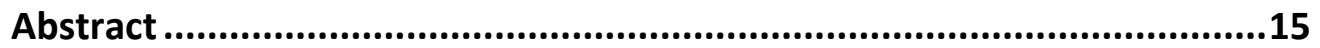

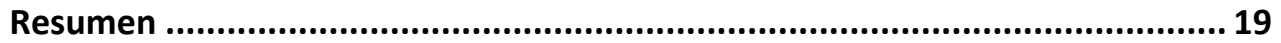

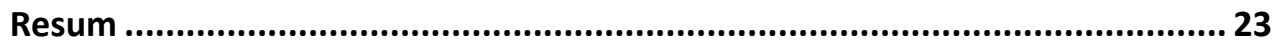

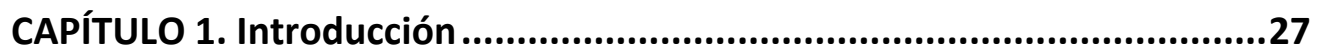

1.1 Objeto y alcance de la tesis ..........................................................................2 27

1.2 Estado del arte y necesidades de la investigación ......................................28

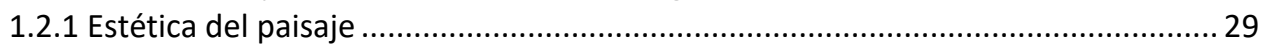

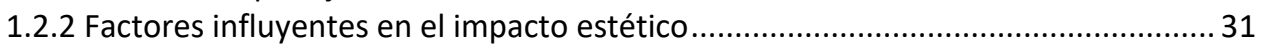

1.2.3 Emociones y percepción estética. Aplicación a los sistemas de energía solar ........ 32

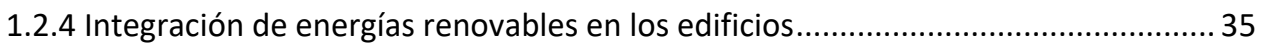

1.2.5 Transición energética e implicación europea en la aceptación social...................... 40

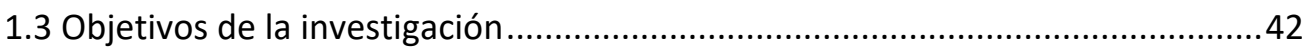

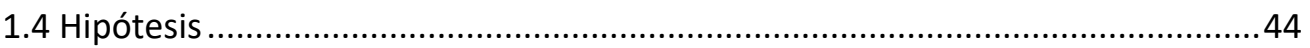

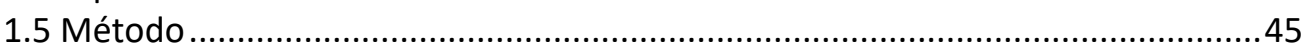

1.5.1 Método utilizado para el estudio de los factores objetivos .................................. 46

1.5.2 Método aplicado en el análisis de la percepción estética subjetiva de los SES....... 46

1.5.3 Metodología utilizada en el análisis de la implicación europea .............................. 47

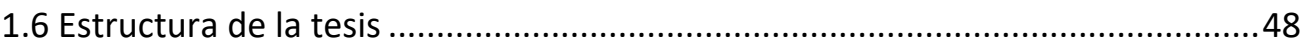

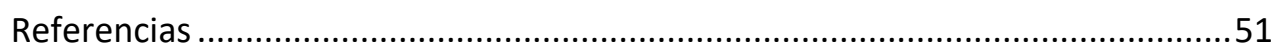

CAPÍTULO 2. Aesthetic impact of solar energy system ..............................61

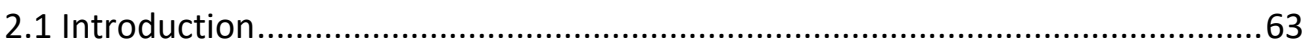

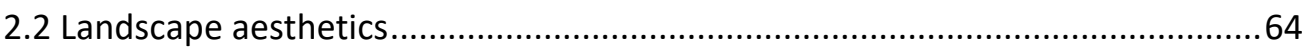

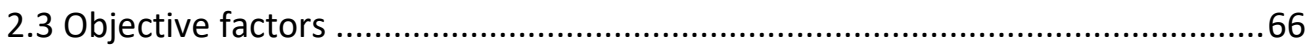

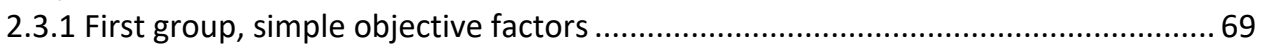

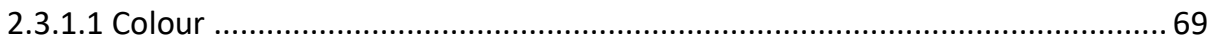

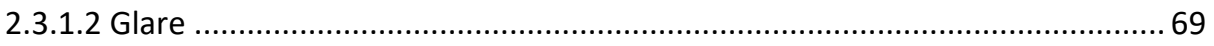

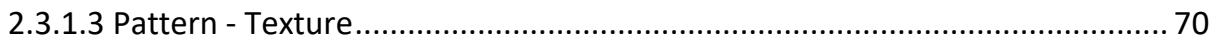

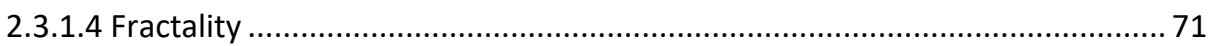

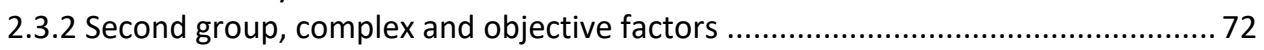


2.3.2.1 Visibility 72

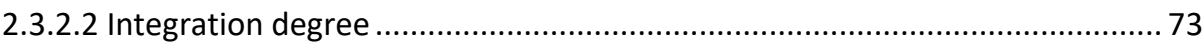

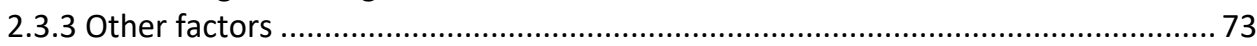

2.4 Emotions and aesthetic perception ........................................................ 74

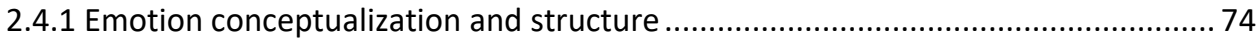

2.4.2 Assessment of aesthetic emotions of landscape.................................................. 75

2.4.3 Assessment of aesthetic emotions of Solar Energy Systems (SES) .......................... 76

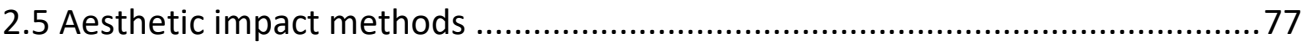

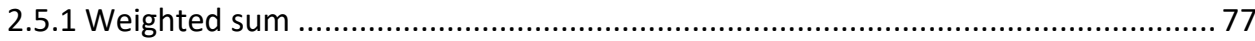

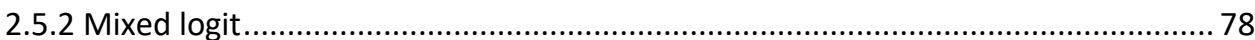

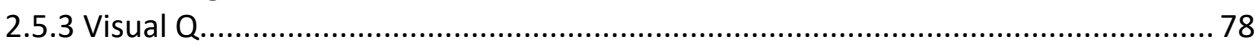

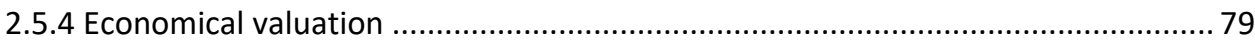

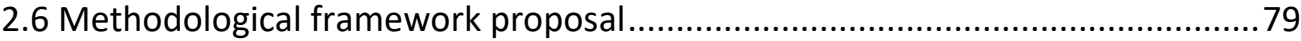

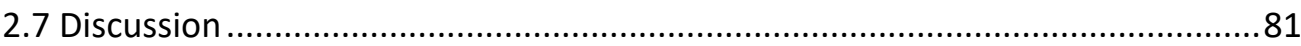

2.7.1 Application to building photovoltaic integration assessment ................................ 84

2.7.2 Application to site location and environmental impact assessment....................... 87

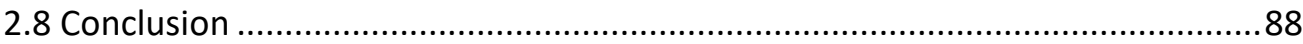

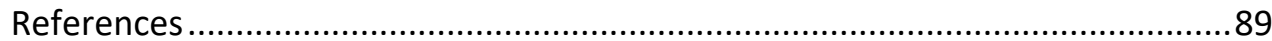

CAPÍTULO 3. Aesthetic perception of photovoltaic integration within new proposals for ecological architecture ..................................................99

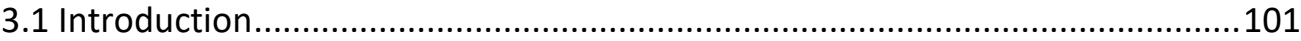

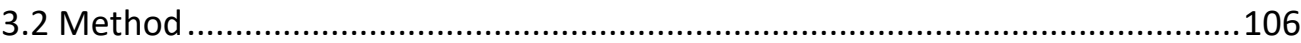

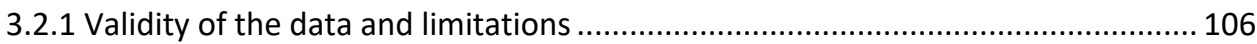

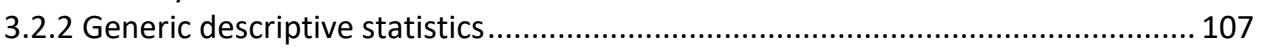

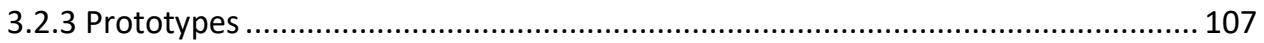

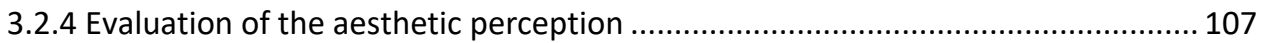

3.3 Results and discussion ........................................................................ 111

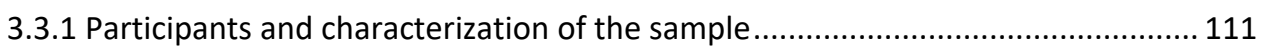

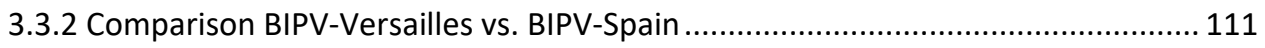

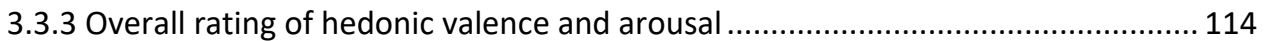

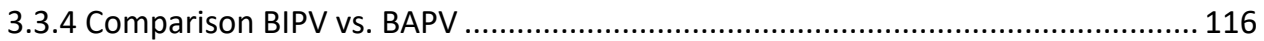

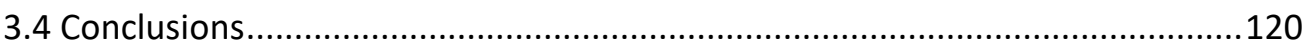

References ........................................................................................... 120

Supplementary information document.................................................. 125

CAPÍTULO 4. Analysis of the aesthetic perception in European-funded projects with actual deployment of renewable energies in cities ...........137

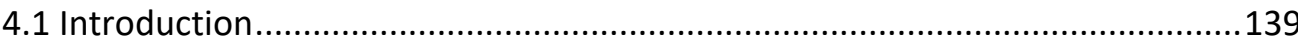

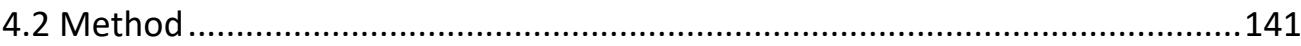

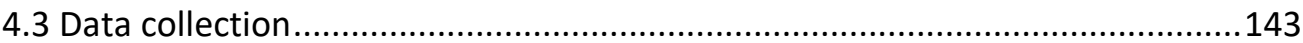

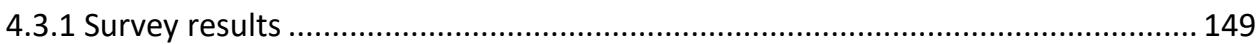

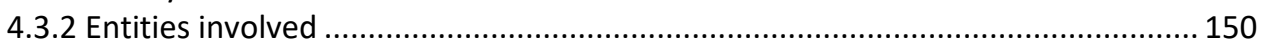

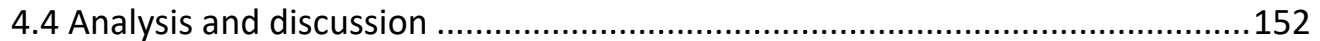

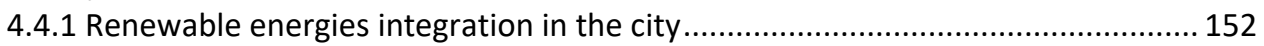




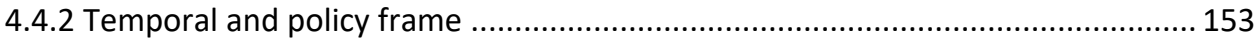

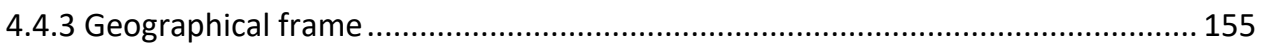

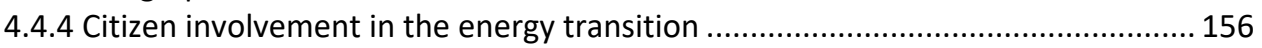

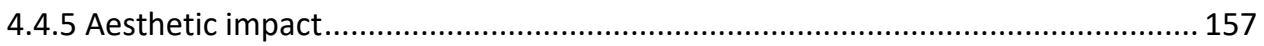

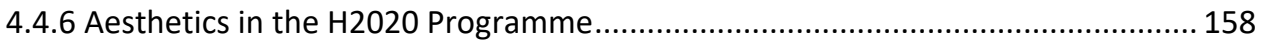

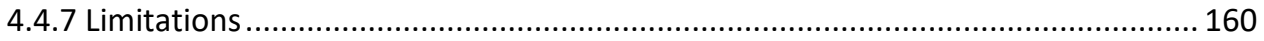

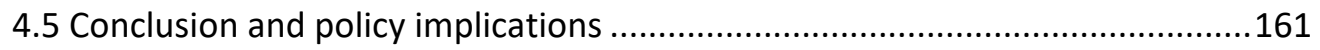

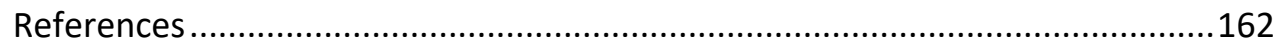

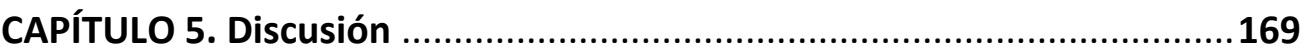

5.1 Impacto estético de los sistemas de energía solar.........................................169

5.1.1 Discusión de los resultados principales ............................................................ 170

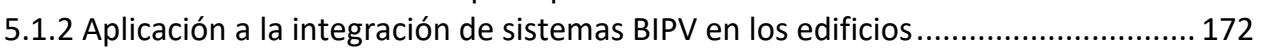

5.1.3 Aplicación a la localización y la evaluación del impacto ambiental ....................... 177

5.2 Percepción social de la integración urbana de la energía solar .......................178

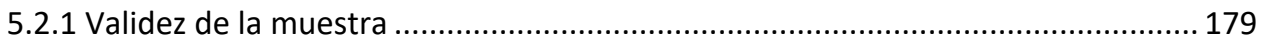

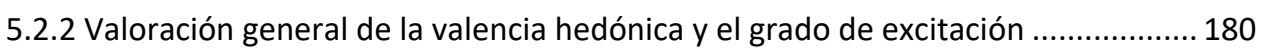

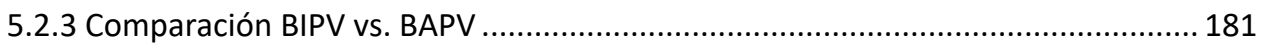

5.3 Implicación europea en la integración urbana de energías renovables y su aceptación social ..................................................................................... 183

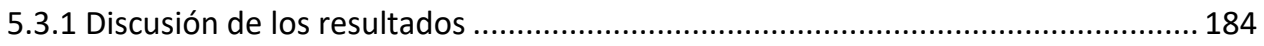

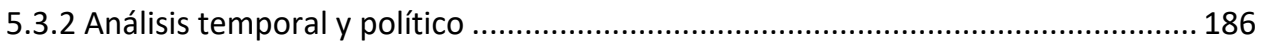

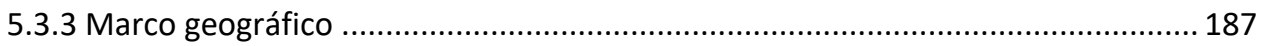

5.3.4 La implicación ciudadana en la transición energética .......................................... 188

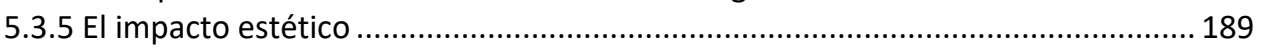

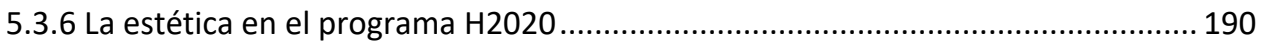

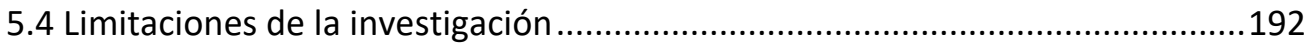

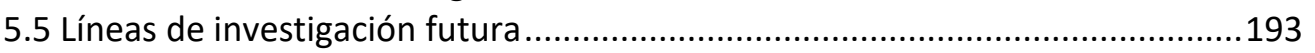

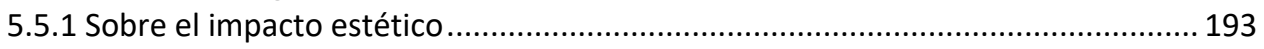

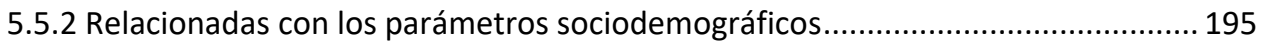

5.5.3 Relacionadas con las tendencias y la implicación europea ................................... 196

5.6 Repercusión de la investigación en la sociedad y en el proceso de implantación de los sistemas de energía solar integrados ....................................................196

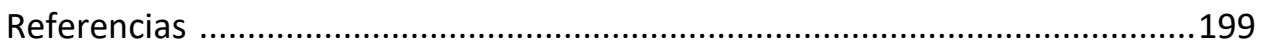

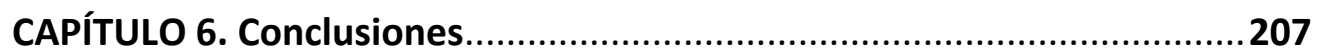

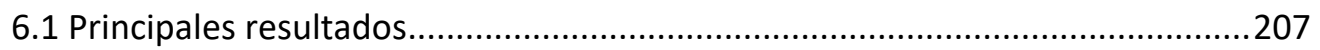

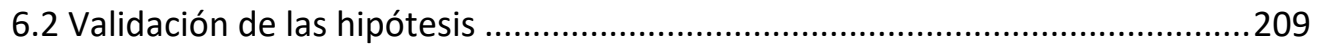

6.3 Cumplimiento de los objetivos ................................................................ 212

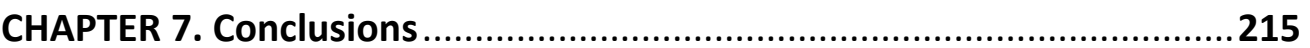

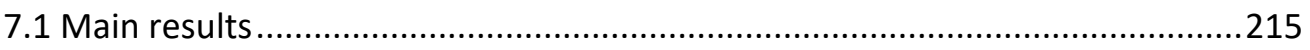

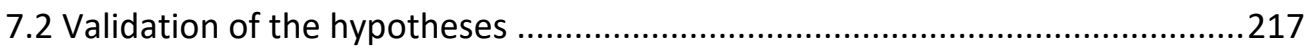

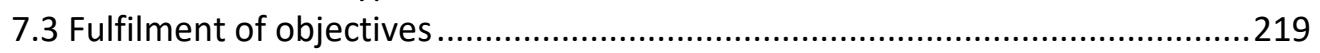

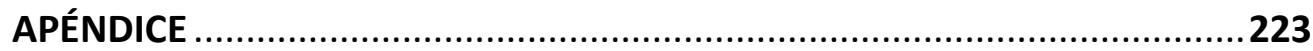




\section{Índice de tablas}

Table 2.1 Relevant information of the literature review of visual/aesthetic influences in solar energy installations

Table 3.1 Parameters used for the descriptive study of the samples. 107

Table 3.2 Mean (and standard deviation) of the sociodemographic variables requested in the survey

Table 3.3 Mean (and standard deviation) of the perception variables hedonic valence and arousal for samples 1 and 2. Comparison of means for the two independent samples (Levene and t test)

Table 3.4 Mean (and standard deviation) of the affective evaluations of hedonic valence and arousal for samples 2 and 3

Table 3.5 Results of the Levene and Student's t tests for the independent samples BIPV and BAPV

Table 3.6 Tests conducted to analyse the influence of the sociodemographic parameters on perception

Table 4.1 Results for projects corresponding to the Interreg Program

Table 4.2 Results for projects corresponding to the FP7 Program

Table 4.3 Results for projects corresponding to the H2020 Program

Table 4.4 Renewable Energy Systems and Energy Storage Systems used in the projects participating in the survey 150

Table 4.5 Data from the research on European-funded projects 152 


\section{Índice de figuras}

Fig. 1.1 Organización de la investigación de la tesis 49

Fig. 2.1 Graphic representation of the qualitative methodological framework 81

Fig. 3.1 The Eco-House prototype exhibited at SDE 2012. BIPV systems are used in the façade and BAPV on the roof 103

Fig. 3.2 The Cité du Soleil, the venue where the Solar Decathlon Europe 2014 was held in Versailles, Paris 105

Fig. 3.3 Prototypes from the SDE 2014 exhibition that were evaluated in the surveys 109

Fig. 3.4 Example of the survey using the SAM method to score the parameters Valence and Arousal.

Fig. 3.5 The prototype Rhome for DenCity from SDE 2014

Fig. 3.6 The prototype Orchid House from SDE 2014 114

Fig. 3.7 Mean values of hedonic valence for each prototype (rating with photographs) .... 115

Fig. 3.8 Mean values of arousal for each prototype (rating with photographs) 116

Fig. 4.1 Methods of the research carried out in two phases. Phase 1: application of three successive filters according to the inclusion criteria. Phase 2: data collection through a survey. 142

Fig. 4.2 Profile of the partners in the European projects surveyed 150

Fig. 4.3 Type of partners in the 16 projects reviewed 151

Fig. 4.4 Number of projects per year applying filters 2 and 3 154

Fig. 4.5 Geographical frame for the $16 \mathrm{EU}$ projects identified that include real implementation of RE on an urban scale: Left: Number in which the country is involved. Right: Number in which the country is coordinator. 155

Fig. 5.1 Representación gráfica del marco metodológico cualitativo 170

Fig. 5.2 Esquema de los parámetros más importantes a tener en cuenta para la evaluación de los sistemas BIPV en el entorno urbano, según el marco metodológico cualitativo propuesto 174

Fig. 5.3 Representación gráfica del ámbito de actuación relacionado con la tesis. 197 


\section{Listado de abreviaturas y acrónimos}

a-Si Silicio amorfo

ACV Análisis del ciclo de vida

CIGS Cobre, indio, galio y selenio

CSL Concentradores solares luminiscentes

EEUU Estados Unidos

EIA Evaluación del impacto ambiental

I+D Investigación y desarrollo

IAPS Sistema internacional de imágenes afectivas

MEEU Modelo de energía de edificios urbanos

ONG Organización no gubernamental

OPV Dispositivos fotovoltaicos orgánicos

SAM Self-Assessment Manikin (Maniquí de autoevaluación)

SD Solar Decathlon

SDE Solar Decathlon Europeo

SES Sistemas de energía solar

SIG Sistemas de Información Geográfica

TRL Nivel de madurez tecnológica

UE Unión Europea 


\section{Abbreviation and acronym list}

AHP Analytical hierarchy process

BAPV Building-applied photovoltaics

$\mathrm{Bf} \quad$ Biofuels

BIPV Building-integrated photovoltaics

CA Compressed air

Cc Concurrence

CNN Convolutional neural networks

$\mathrm{Cl} \quad$ Colour

CSP Computer simulation pictures

EIA Environmental impact assessment

ESS Energy storage system

EU European Union

F $\quad$ Frame (chapter 1)

F $\quad$ Flywheels (chapter 3)

FD Fractal dimension

FP7 EU's research and innovation funding programme for 2007-2013

$\mathrm{Fr} \quad$ Fragmentation of the installation

GIS Geographical information system

GI Glare

Gt Geothermal

$\mathrm{H} \quad$ Hydrogen storage

H2020 EU's research and innovation funding programme for 2014-2020

He Hydroelectric

IAPS International Affective Pictures System

ID Integration degree

IRENA International renewable energy agency

KE Kind of environment assessed

LCA Life cycle assessment

LSC Luminescent solar concentrators

LT Lithium batteries

NGO Non-governmental organization 
OAlssp Indicator of objective aesthetic impact (in Torres-Sibille et al., 2009)

$\mathrm{Pa}$ Pattern

$\mathrm{Ph} \quad$ Photos

$\mathrm{PH} \quad$ Pumped hydro

PoV Point of view

PV Photovoltaic

R Rural landscapes

R+D Research and development

RE Renewable energies

RES Renewable energy system

RfB Redox flow batteries

SAM Self-assessment manikin

SC Super-capacitors

SD Solar Decathlon

SDE Solar Decathlon Europe

SES Solar energy system

SET Strategic energy technology

Sh Shape

SP Surface patterns

TA Topographic alterations

$\mathrm{Tr} \quad$ Transparency

TRL Technological readiness level

TS Thermal solar

U Urban landscapes

UBEM Urban building energy models

USA United States of America

Vi Visibility

VS Visual saliency

WE Wind energy

WP Work package

WTA Willingness to accept

WTP Willingness to pay 


\section{Anexo: Trabajos publicados}

\section{Publicaciones incluidas en esta Tesis}

1. Núria Sánchez-Pantoja, Rosario Vidal, M. Carmen Pastor. Aesthetic Impact of Solar Energy Systems. Renewable and Sustainable Energy Reviews, 2018, 98, 227-238. DOI: 10.1016/j.rser.2018.09.021

Factor de impacto (JRC): 10,556

2. Núria Sánchez-Pantoja, Rosario Vidal, M. Carmen Pastor. Aesthetic Perception of Photovoltaic Integration within new Proposals for Ecological Architecture. Sustainable Cities and Society, 2018, 39, 203-214. DOI: 10.1016/J.SCS.2018.02.027

Factor de impacto (JRC): 4,624

3. Núria Sánchez-Pantoja, Rosario Vidal, M. Carmen Pastor. Analysis of the Aesthetic Perception in European-funded Projects with Actual Deployment of Renewable Energies in Cities. Pending acceptance for publication in the scientist journal Energy Policy. Factor de impacto (JRC): 5,042

\section{Publicaciones no incluidas en esta Tesis, relacionadas con el tema}

1. Núria Sánchez-Pantoja, Teresa Gallego, Rosario Vidal, 2015. Photovoltaic technologies used in the prototypes of Solar Decathlon Europe 2014, in: 10th Conference on Advanced Building Skins. ISBN 978-3-98120538-1. "Advanced Building Skins. pp. 67-76".

2. Núria Sánchez-Pantoja, Rosario Vidal, 2017. Título del Póster: Diferencias de género en la percepción estética de la integración fotovoltaica en los prototipos de vivienda solar de SDE 2014. XX International Congress of the Institut Universitari d'Estudis Feministes i de Gènere Purificación Escribano "Salut, emocions I Gènere".

3. Núria Sánchez-Pantoja; Rosario Vidal, 2017. Ebook: Género y Percepción Estética. Caso de Estudio: Solar Decathlon Europe 2014. Colección ePsique, Universitat Jaume I. ISBN 978-84-16546-58-9.

4. Rosario Vidal, Núria Sánchez-Pantoja, German Martínez. Life Cycle Assessment of a Residential Building with Cross-laminated Timber Structure in Granada-Spain. Informes de la Construcción 2019, 71, 3-7. http://doi.org/drx2 


\section{AgRAdeCIMIENTOS}

Mi primer y más sincero agradecimiento se lo quiero dar a mi tutora y directora de tesis, Prof. Sari Vidal, por guiarme y acompañarme en este largo camino desde el primer día hasta el final. Por su apoyo, por su exigencia, por todo lo que me ha enseñado y por haber confiado en mí siempre durante estos años de doctorado. Trabajar al lado de una persona con sus conocimientos y experiencia ha contribuido enormemente a mi crecimiento profesional y personal. Igualmente, extiendo este agradecimiento a mi también directora y amiga, Prof. Mamen Pastor, por su apoyo incondicional y por su ayuda en la vertiente más humanista de la tesis doctoral. Siento una gran admiración por estas dos excelentes investigadoras y ha sido muy enriquecedor dar a la investigación este enfoque multidisciplinar que sin duda ha contribuido al éxito del trabajo.

Por otro lado, el emprendimiento de esta tesis no hubiera sido posible sin el empuje y el apoyo inicial de mi compañera, Prof. Teresa Gallego, quien ha mostrado desde el inicio una total confianza en mi trabajo $y$ ha sido un ejemplo de esfuerzo $y$ superación en todo momento. Sus ánimos y sus consejos me han ayudado constantemente a mantener el entusiasmo por seguir adelante.

Quiero dar las gracias al Prof. Stefan Gößling-Reisemann, responsable de mi estancia de investigación en la Universidad de Bremen, que lamentablemente falleció durante el periodo de permanencia en Alemania. Sin lugar a duda, su experiencia hubiera supuesto una valiosa aportación para mi investigación. Igualmente, quisiera agradecer a Torben Stührmann su ayuda y su dedicación en un momento tan complicado para él.

Fue un honor para mí contar con la ayuda económica ofrecida por la Fundación Balaguer-Gonel Hermanos para realizar la estancia de investigación en Alemania y poder optar así a la mención de doctora internacional.

También quiero agradecer el apoyo y la compañía durante estos años a los compañeros que he tenido en el GID y a Sara. Juntos hemos compartido proyectos, problemas y cafés, con los que hemos aprendido mucho y que han hecho más amenos los malos momentos.

Mi agradecimiento más profundo e inmensurable va dirigido a mi familia y especialmente a mis padres, Emilia y Albert, por haber confiado siempre en mí y no haber coartado nunca mis expectativas. Su cariño, la educación que me han dado y 
su apoyo incondicional me han hecho pensar siempre que soy capaz de llegar donde me proponga.

Igual de profundo e inmensurable es mi agradecimiento a Marco por su tolerancia. Por apoyarme, acompañarme y aguantarme todo este tiempo, en los mejores y en los peores momentos. Por escucharme, interesarse por mi tesis y valorar mi trabajo animándome siempre a seguir. Y también a Aika y a Pau por su paciencia, pero sobre todo por su capacidad para transmitirme energía.

Muchas gracias a todos los que, de una manera $u$ otra, habéis contribuido a mi crecimiento profesional y personal durante todo este tiempo; y en especial a mis amigos por ayudarme a desconectar y relajarme con unas risas cuando lo he necesitado. 


\section{ABSTRACT}

The climate change that threatens the current system of life has led to the emergence of new energy policies in recent years, mostly driven by European countries, in order to reduce the consumption of fossil fuels and increase the use of renewable energies. Not in vain, in recent decades there have been significant advances in technologies aimed at energy generation using alternative renewable resources.

Large areas of land in the rural environment were used at the beginning of the effective implementation of renewable energy systems. However, in the last 10-15 years their presence is increasing into the buildings, as well as in other spaces in the urban environment. These technologies inevitably cause an intrusion into the landscape and a visual impact that is not always socially accepted, regardless of the type of environment in which they are implemented. The research carried out in this thesis has focused on the aesthetic perception of such facilities, with special attention to the integration of the solar energy systems in cities, as they are the most inhabited places and therefore where the greatest number of people can be affected, as well as on solar energy systems, as they are the most commonly used as shown in our results.

Aesthetic perception is a topic widely discussed in the scientific literature; however, the specific aesthetic impact caused by solar energy systems located in the cities is a very recent issue that has scarcely been addressed in previous research. This doctoral dissertation aims to positively contribute preliminary research in this field of study, by establishing an elementary conceptual framework that includes several relevant lines of research. The analysis of the aesthetic impact caused by the installations has an objective and a subjective component. Thus, the first line of research focuses on the objective factors that are most influential, while the second one addresses the subjective perception experienced by the individual. These two lines of research are also necessarily related to each other. Finally, considering the European geographical scope, a third line of research focused on the level of concern of entities that are carrying out the initial phase of promotion and implementation of the systems for this aesthetic impact. Formally, the current thesis is presented as a compendium of two studies previously published in scientific journals of impact (Q1) and a third one pending acceptance for publication. These three studies, taken together, shape our conceptual framework, from which the most relevant results are jointly discussed in a final chapter of conclusions.

In the second chapter an in-depth review is made of the existing literature related to the objective factors that influence aesthetic perception, as well as the methods that relate the objective factors to the subjective perception of the impact caused by solar energy systems. This review revealed a total lack of consensus in the previous 
literature on the most relevant objective factors. Thus, for the first time in the literature, this study establishes -based on previous literature-, that the most influential objective factors in the aesthetic perception of solar energy systems are visibility and integration degree. Additionally, a qualitative methodological framework to assess the aesthetic impact is proposed, in which this impact is divided into 3 sub-impacts: land use, the solar energy system (SES) and glare.

In the third chapter, the aesthetic perception from a subjective point of view is addressed. Since no previous research had collected data on the aesthetic perception of the solar energy systems directly from society, a survey was conducted using as a sample scenario the solar housing prototypes from the Solar Decathlon Europe international competition held in Versailles in 2014. In general, we concluded that the perception of buildings with solar energy systems is positive. Prototypes with integrated systems in the enclosure (BIPV) were also found to receive higher ratings in pleasantness compared to those with non-integrated systems housed on the roof (BAPV). The results also revealed, in line with the results of the study in the previous chapter, that the degree to which the observer appreciated the installation influenced his assessment. Finally, the only sociodemographic parameter that turned out to have some influence on the assessment was the age of the respondent, with the youngest people showing the greatest emotional intensity and those who best accepted the more industrially styled BAPV systems.

Finally, the fourth chapter analyzes the involvement of European funding programmes with the actual implementation of renewable energy systems, but also the degree of concern of the entities involved with the aesthetic impact generated to society by the projects they develop. To this end, a review was carried out of the 5 European funding programmes most related to the promotion of renewable energies and the mitigation of climate change, including a total of almost 14,000 projects of which only $0.1 \%$ were identified as being aimed at implementing a real installation of renewable energies on an urban scale. However, since 2013 there is a growing trend of potential projects with this objective. The most implemented renewable energy system was clearly photovoltaic technology and as for energy storage systems, the most used were lithium batteries. From a geographical point of view, there is a very uneven participation, with Spain and Belgium standing out for their greater involvement, followed by Italy, Germany and France. The H2020 programme was the one that included the most projects that met the requirements of the study. Although this programme has never included the aesthetic impact of these technologies as a key issue, since 2014 the word "aesthetics" has started to appear in the call related to the architectural integration of photovoltaic technology.

To conclude the thesis, chapter 5 discusses the results, justifying the fulfilment of the objectives of the thesis and underlining the connection of these results with prior works. It also establishes relations among the various lines of research addressed in the thesis, proposes new lines of future research and analyses the repercussion that 
this research may have on society, as well as on the process of implementing integrated solar energy systems in the city and the different agents involved in this process: public administration, the solar energy industry, architects and the citizens themselves. 


\section{RESUMEN}

El cambio climático que amenaza el sistema de vida actual tal y como lo conocemos ha provocado la aparición de nuevas políticas energéticas en los últimos años, mayoritariamente impulsadas por Europa, con el fin de reducir el consumo de combustibles fósiles y potenciar el uso de las energías renovables. No en vano, en las últimas décadas ha habido avances muy significativos en tecnologías destinadas a la generación de energía utilizando recursos renovables alternativos.

La implantación efectiva de sistemas de energías renovables comenzó utilizando grandes extensiones de terreno en el entorno rural, pero en los últimos 10-15 años hemos sido testigos de su presencia cada vez mayor en edificios, así como en otros espacios del entorno urbano. Estas tecnologías provocan inevitablemente una intrusión en el paisaje y un impacto visual que no siempre cuenta con la aceptación social, independientemente del tipo de entorno en el que nos encontremos. La investigación llevada a cabo en esta tesis tiene como tema principal la percepción estética de dichas instalaciones, con especial atención a la integración de los sistemas de energía solar en las ciudades, por ser los lugares más habitados y por tanto donde puede afectar a un mayor número de gente, y en los sistemas de energía solar, por ser aquellos más comúnmente utilizados como se verá en los resultados.

La percepción estética es un tema ampliamente tratado en la literatura científica, sin embargo, el impacto estético específico que provocan los sistemas de energía solar en la ciudad es un tema muy reciente que escasamente ha sido tratado en investigaciones previas. Esta tesis pretende ser un punto de partida significativo para la investigación en este ámbito de estudio, puesto que establece un marco conceptual elemental que incluye varias líneas de investigación relevantes. El análisis del impacto estético causado por las instalaciones tiene una componente objetiva y otra subjetiva. Así, una primera línea de investigación analiza los factores objetivos que resultan más influyentes, mientras que una segunda línea aborda la percepción subjetiva que experimenta el individuo. Necesariamente estas dos líneas de investigación están relacionadas entre sí. Por último, considerando el ámbito geográfico europeo, una tercera línea de investigación estudia el nivel de preocupación de las entidades que están llevando a cabo la fase inicial de fomento e implantación de los sistemas por este impacto estético. Formalmente, la tesis se presenta como un compendio de dos trabajos previamente publicados en revistas científicas de impacto y un tercero que está pendiente de aceptación para ser publicado. En conjunto, los tres trabajos conforman un marco conceptual completo, del que al final se discuten y exponen los resultados más relevantes.

En el segundo capítulo se hace una revisión profunda de la literatura existente sobre los factores objetivos que influyen en la percepción estética, así como los métodos que relacionan los factores objetivos con la percepción subjetiva del impacto 
provocado por los sistemas de energía solar. Esta revisión reveló una total falta de consenso en la literatura previa sobre los factores objetivos más relevantes. Así, por primera vez en la literatura, este estudio determina, en base a la literatura previa, que la visibilidad y el grado de integración son los factores objetivos más influyentes en la percepción estética de los sistemas de energía solar. Adicionalmente, como resultado se propone un marco metodológico cualitativo para evaluar el impacto estético, en el que dicho impacto queda dividido en 3 sub-impactos: el uso del suelo, el propio sistema de energía solar (SES) y el deslumbramiento.

En el tercer capítulo se aborda la percepción estética desde un punto de vista subjetivo. Para ello, puesto que en ningún estudio anterior se habían recogido datos directamente de la sociedad sobre la percepción estética de los sistemas de energía solar, se realizó una encuesta tomando como escenario los prototipos de vivienda solar del concurso internacional Solar Decathlon Europe celebrado en Versalles en 2014. De esta forma se pudo confirmar que en general la percepción de los edificios con sistemas de energía solar es positiva. Asimismo, se comprobó que los prototipos con sistemas integrados en la envolvente (BIPV) recibían valoraciones superiores a aquellos con sistemas no integrados albergados en la cubierta (BAPV). Los resultados revelaron también, coincidiendo con los resultados del estudio del capítulo anterior, que el grado en que el observador apreciaba la instalación influyó en su valoración. Por último, el único parámetro sociodemográfico que resultó tener alguna influencia en la valoración fue la edad del encuestado, siendo los más jóvenes los que mayor intensidad emocional mostraron y los que mejor aceptaron los sistemas BAPV con una estética más industrial.

Por último, en el cuarto capítulo se analiza la implicación de los programas de financiación europeos con la implementación real de sistemas de energías renovables, pero también el grado de preocupación de las entidades que intervienen con el impacto estético que generan a la sociedad los proyectos que llevan a cabo. Para ello, se realizó una revisión de los 5 programas de financiación europea más relacionados con el fomento de las energías renovables y la mitigación del cambio climático, incluyendo un total de casi 14000 proyectos de los que solo un $0,1 \%$ se identificaron como destinados a implementar una instalación real de energías renovables a escala urbana. Sin embargo, desde el año 2013 hay una tendencia creciente de potenciales proyectos con este objetivo. El sistema de energía renovable más implementado fue claramente la tecnología fotovoltaica; en cuanto a los sistemas de almacenaje de energía, el más utilizado fueron las baterías de litio. Desde el punto de vista geográfico hay una participación muy desigual, destacando por su mayor implicación España y Bélgica, seguidas de Italia, Alemania y Francia. El programa H2020 resultó ser el que abarcó más proyectos que cumplieran los requisitos del estudio. Aunque este programa nunca ha incluido como tema clave el impacto estético de estas tecnologías, desde 2014 comienza a aparecer la palabra "estética" en la convocatoria relacionada con la integración arquitectónica de tecnología fotovoltaica. 
Para finalizar la tesis, en el capítulo 5 se discuten los resultados, justificando el cumplimiento de los objetivos de la tesis y subrayando la conexión de estos resultados con otras investigaciones. Asimismo, se establecen relaciones entre las diversas líneas de investigación abordadas en la tesis, se proponen nuevas líneas de investigación futuras y se analiza la repercusión que esta investigación puede tener en la sociedad, así como en el proceso de implantación de los sistemas de energía solar integrados en la ciudad y los diferentes agentes que en dicho proceso intervienen: administración pública, sector industrial de la energía solar, arquitectos y los propios ciudadanos. 


\section{RESUM}

El canvi climàtic que amenaça el sistema de vida actual tal i com el coneixem ha provocat l'aparició de noves polítiques energètiques en el darrers anys, majoritàriament impulsades per Europa, amb la fi de reduir el consum de combustibles fòssils i potenciar l'ús de les energies renovables. No en va, en les últimes dècades hi ha hagut avanços molt significatius en tecnologies destinades a la generació d'energia, utilitzant recursos renovables alternatius.

La implantació efectiva de sistemes d'energies renovables es va iniciar utilitzant grans extensions de terreny de l'entorn rural, però en els darrers 10-15 anys hem estat testimonis de la seua presència cada vegada major en els edificis, així com en altres espais de l'entorn urbà. Aquestes tecnologies provoquen inevitablement una intrusió en el paisatge i un impacte visual que no sempre compta amb l'acceptació social, independentment del tipus d'entorn en el que ens trobem. La investigació duta a terme en aquesta tesi té com a tema principal la percepció estètica d'aquestes instal-lacions, amb especial atenció a la integració dels sistemes d'energia solar en les ciutats, per ser els llocs més habitats i per tant on pot afectar a un major nombre de gent, i en els sistemes d'energia solar, per ser aquells més comunament utilitzats com es veurà en els resultats.

La percepció estètica és un tema àmpliament tractat en la literatura científica, no obstant això, l'impacte estètic específic que provoquen els sistemes d'energia solar en la ciutat és un tema molt recent que escassament ha estat tractat en investigacions prèvies. Aquesta tesi pretén ser un punt de partida significatiu per a la investigació en aquest àmbit d'estudi, ja que estableix un marc conceptual elemental que inclou diverses línies d'investigació rellevants. L'anàlisi de l'impacte estètic causat per les instal-lacions té una component objectiva i una altra subjectiva. Així, una primera línia d'investigació analitza els factors objectius que resulten més influents, mentre que una segona línia aborda la percepció subjectiva que experimenta l'individu. Necessàriament aquestes dues línies d'investigació estan relacionades entre si. Per últim, considerant l'àmbit geogràfic europeu, una tercera línia d'investigació estudia el nivell de preocupació de les entitats que estan duent a terme la fase inicial de foment i implantació dels sistemes per aquest impacte estètic. Formalment, la tesi es presenta com un compendi de dos treballs prèviament publicats en revistes científiques d'impacte (Q1) i un tercer que està pendent d'acceptació per a ser publicat. En conjunt, els tres treballs conformen un marc conceptual complet, del que al final es discuteixen i s'exposen els resultats més rellevants.

En el segon capítol es fa una revisió en profunditat de la literatura existent sobre els factors objectius que influeixen en la percepció estètica, així com els mètodes que relacionen els factors objectius amb la percepció subjectiva de l'impacte provocat 
pels sistemes d'energia solar. Aquesta revisió va revelar una total falta de consens en la literatura prèvia sobre els factors objectius que són més rellevants. Així, per primera vegada en la literatura aquest estudi determina, basant-se en la literatura prèvia, que la visibilitat i el grau d'integració són els factors objectius més influents en la percepció estètica dels sistemes d'energia solar. Addicionalment, com a resultat es proposa un marc metodològic qualitatiu per avaluar l'impacte estètic, en el que aquest impacte queda dividit en 3 sub-impactes: I'ús del sòl, el propi sistema d'energia solar (SES) i l'enlluernament.

En el tercer capítol s'aborda la percepció estètica des d'un punt de vista subjectiu. Amb aquesta finalitat, donat que en cap estudi anterior s'havien recollit dades sobre la percepció estètica dels sistemes d'energia solar directament de la societat, es va realitzar una enquesta considerant com a escenari d'estudi els prototipus d'habitatge solar del concurs internacional Solar Decathlon Europe celebrat a Versalles el 2014. D'aquesta forma es va poder confirmar que en general la percepció dels edificis amb sistemes d'energia solar és positiva. Així mateix, es comprovà que els prototipus amb sistemes integrats en l'envoltant (sistemes BIPV) rebien valoracions superiors a aquells amb sistemes no integrats albergats en la coberta (sistemes BAPV). Els resultats revelaren també, coincidint amb els resultats de l'estudi del capítol anterior, que el grau en que l'observador apreciava la instal·lació influïa en la seua valoració. Finalment, l'únic paràmetre sociodemogràfic que va resultar tenir alguna influència en la valoració va ser l'edat de l'enquestat, sent els més joves els qui major intensitat emocional mostraren i els qui millor acceptaren els sistemes BAPV amb una estètica més industrial.

Per últim, en el quart capítol s'analitza la implicació dels programes de finançament europeus amb la implementació real de sistemes d'energies renovables, però també el grau de preocupació de les entitats que intervenen amb l'impacte estètic que generen a la societat els projectes que desenvolupen. Amb aquesta finalitat, es van revisar els 5 programes de finançament europeu més relacionats amb el foment de les energies renovables i la mitigació del canvi climàtic, incloent un total de quasi 14000 projectes dels que tan sols un $0,1 \%$ es van identificar com a destinats a implementar una instal-lació real d'energies renovables a escala urbana. No obstant això, des de l'any 2013 hi ha una tendència creixent de potencials projectes amb aquest objectiu. El sistema d'energia renovable més implementat fou clarament la tecnologia fotovoltaica i pel que fa als sistemes d'emmagatzematge d'energia, el més utilitzat fou la bateria de liti. Des d'un punt de vista geogràfic hi ha una participació molt desigual, destacant per la seua major implicació Espanya i Bèlgica, seguides d'Itàlia, Alemanya i França. El programa H2020 va resultar ser el que va incloure més projectes que compliren els requisits de l'estudi. Encara que aquest programa no ha inclòs mai com a tema clau l'impacte estètic d'aquestes tecnologies, des de 2014 la paraula "estètica" comença a estar present en la convocatòria relacionada amb la integració arquitectònica de tecnologia fotovoltaica. 
Per finalitzar la tesi, en el capítol 5 es discuteixen els resultats, justificant el compliment dels objectius de la tesi i subratllant la connexió d'aquests resultats amb altres investigacions. Així mateix, s'estableixen relacions entre les diverses línies d'investigació abordades en la tesi, es proposen noves línies d'investigació futures i s'analitza la repercussió que aquesta investigació pot tenir en la societat, així com en el procés d'implantació dels sistemes d'energia solar integrats en la ciutat i els diferents agents que en aquest procés intervenen: administració pública, sector industrial de la energia solar, arquitectes i els propis ciutadans. 


\section{CAPÍTULO 1. INTRODUCCIÓN}

\subsection{Objeto y alcance de la tesis}

En las últimas décadas, la amenaza del cambio climático ha forzado a la comunidad científica a investigar formas de reducir el consumo de recursos fósiles, así como implementar el uso de energías renovables para disminuir las emisiones de gases de efecto invernadero que son, en gran medida, responsables del cambio climático (EU, 2003, 2010a, 2014). Las energías renovables, como pueden ser los sistemas de energía solar o eólica, ocupan normalmente grandes superficies de terreno que producen una alteración del entorno, y son causa de crítica por una parte de la sociedad que no acepta esta intrusión en el paisaje. Las instalaciones que abarcan grandes extensiones se sitúan generalmente en entornos rurales. Sin embargo, el número de personas afectadas por el impacto visual en ese caso es menor, puesto que la mayor parte de la población vive y desarrolla su actividad en las ciudades. El entorno urbano constituye -aunque el área implicada sea menor-el contexto donde la alteración del paisaje puede afectar a un mayor número de personas, siendo los sistemas de energía solar la tecnología renovable más utilizada en los edificios.

A este respecto, el impacto estético producido por la integración de las energías renovables en la ciudad es un tema de interés bastante reciente, a pesar de que la percepción estética del paisaje haya sido ampliamente investigada en la literatura (Daniel, 2001; Lothian, 1999; Ulrich, 1986). Precisamente, nuestra investigación ofrece una perspectiva novedosa en este ámbito de estudio, abriendo nuevas líneas de trabajo y estableciendo un marco conceptual que puede resultar atractivo y relevante para investigaciones futuras.

Teniendo en cuenta que la energía renovable más utilizada en las ciudades es la solar, una primera línea de estudio aborda la evaluación del impacto estético de los sistemas de energía solar. En la tesis se analizan los factores objetivos que influyen en el impacto estético y se propone un nuevo marco metodológico cualitativo que pueda servir de base para futuras investigaciones en este ámbito. Para realizar dicho análisis de los factores objetivos más influyentes se llevó a cabo una profunda revisión de la literatura previa, cuyos resultados podrían ser de gran ayuda para los técnicos que proyectan sistemas de energía solar en la fase de diseño.

Una segunda línea de trabajo, sobre la que no existe literatura previa, consiste en analizar el impacto real que causa en los ciudadanos el uso de estas tecnologías en la ciudad. El motivo principal para la ausencia de datos empíricos metodológicamente validados radica en la dificultad que supone recrear escenarios realistas con edificios que nos sirvan para evaluar el impacto estético que producen. Sin embargo, la exposición de prototipos de viviendas solares del concurso internacional Solar Decathlon Europe (celebrado en junio de 2014) fue considerado 
un escenario de trabajo muy apropiado para recoger datos de los visitantes. De esta forma, por primera vez en la literatura, esta tesis doctoral muestra resultados sobre el impacto estético de la integración de energías renovables en los edificios obtenidos directamente de ciudadanos.

Finalmente, los programas europeos están financiando, cada vez con mayor frecuencia, proyectos relacionados con las instalaciones de energías renovables y su integración en la ciudad a gran escala, por lo que la tercera línea de investigación se centró en identificar el interés de los programas de financiación europea por proyectos destinados a la implementación real de este tipo de instalaciones en el entorno urbano, así como su implicación en la evaluación del impacto estético que producen en la sociedad. Se revisaron los cinco programas más relevantes en materia de energías renovables y mitigación del cambio climático, incluyendo casi 14000 proyectos en el estudio. Finalmente, se llevó a cabo una discusión teórica de los resultados, considerando la evolución a lo largo del tiempo, el marco político y geográfico, así como aspectos estéticos.

Globalmente, el objeto general de la presente tesis doctoral tiene una importante componente social y, en consecuencia, la investigación desarrollada no sigue un método puramente cuantitativo, con un planteamiento de hipótesis definidas a priori. Por el contrario, en algunas etapas nuestra investigación toma un enfoque cualitativo y más humanista, adaptando la metodología y la estrategia de estudio a las necesidades de cada fase.

\subsection{Estado del arte y necesidades de la investigación}

La amenaza del cambio climático ha provocado en las últimas décadas un incremento notable de la investigación relacionada con la reducción del consumo energético de nuestros edificios y con las tecnologías que aprovechan las fuentes de energía renovable. Atendiendo a las exigencias europeas de fomentar la explotación de sistemas de energías renovables (EU, 2010b, 2009), investigadores y sectores productivos han trabajado en la búsqueda de soluciones que sean viables para permitir la implementación de estos sistemas en nuestro modelo energético.

De forma progresiva, la UE ha fomentado una gestión energética sostenible y competitiva que en 2015 culminó en la elaboración de la estrategia Marco para una Unión de la Energía resiliente con una política climática prospectiva (EU, 2015a). De esta forma, la UE se comprometió a convertirse en líder mundial de las energías renovables y fijó como objetivo una cuota mínima del $27 \%$ de energía renovable consumida en la UE para el año 2030 (EU, 2015b).

La implantación de sistemas de energías renovables, principalmente eólica y solar, tuvo su inicio en entornos rurales, ocupando grandes extensiones de terreno y formando lo que se han Ilamado comúnmente "parques eólicos" y "huertos solares". 
En muchas ocasiones y de forma inevitable, estas instalaciones alteran paisajes que habían permanecido prácticamente inalterables durante años, salvo por la introducción de la agricultura extensiva (Mérida-Rodríguez et al., 2015; Torres-Sibille et al., 2009). El análisis de esta alteración del paisaje, tanto en entornos rurales como urbanos, requiere la consideración de numerosos aspectos que difícilmente se han explorado conjuntamente en la literatura previa. Precisamente, en los siguientes apartados se describe cada uno de estos factores de forma resumida. En primer lugar, resulta necesario analizar el estado del arte sobre la estética del paisaje con especial atención a la integración de las energías renovables en el mismo. Por otro lado, considerando el impacto estético que producen las instalaciones, parece inevitable revisar la literatura relacionada con los factores más influyentes, así como la valoración emocional propia del observador. En los últimos años, la presencia de energías renovables en la ciudad ha sido cada vez más notoria, por lo que también se examina la investigación relacionada con la integración de energías renovables en los edificios. Y por último, teniendo en cuenta la forzosa transición energética que persigue la progresiva implementación de energías renovables, se analiza la implicación europea para conseguir la aceptación social de estas tecnologías.

\subsubsection{La estética del paisaje}

La percepción estética del paisaje ha sido objeto de numerosos estudios incluyendo entornos rurales y urbanos (Daniel, 2001; Lothian, 1999; Tveit et al., 2006; Ulrich, 1986). Inicialmente, el estudio del paisaje se abordó desde dos ámbitos (Plieninger et al., 2015): (1) la investigación geográfica, y (2) el arte y la pintura de paisajes, convirtiéndolos en el propio objeto de admiración estética. En el siglo XX se introducen nuevas herramientas y conceptos que enriquecieron este planteamiento incluyendo nuevas disciplinas. Por ejemplo, con un enfoque geográfico y antropológico se tuvieron en cuenta las actividades humanas y su relación con la geografía. Desde la llamada geografía cultural se incorporaron aspectos estéticos a la tradición geográfica y artística. Y, más recientemente, se introdujo la geografía social que explora aspectos como el bienestar social e individual. La suma de diferentes disciplinas dio lugar a nuevos ámbitos de estudio como son la arquitectura del paisaje y la planificación del paisaje.

Planificar el paisaje implica de alguna forma gestionar los cambios que en él se producen. Cambios que sabemos que pueden afectar al bienestar de las personas $(E U, 2000)$ igual que sabemos que, de forma intencionada o no, el uso del suelo influye en la biodiversidad y en los ecosistemas. En consecuencia, para evaluar el impacto causado por el uso del suelo consideramos dos tipos de intervenciones: la transformación del suelo (o cambio de uso) y la ocupación del suelo (Lindeijer, 2000). Cuando hacemos un análisis del ciclo de vida para cuantificar el daño causado se consideran dos principales impactos (Koellner et al., 2013): el potencial perjuicio a la biodiversidad y el potencial perjuicio a los servicios del ecosistema (aquellos beneficios que los humanos obtenemos de los ecosistemas como resultado de la 
propia interacción con el ecosistema). Pero, además, debemos tener en cuenta que los paisajes presentan diversos valores interconectados, también susceptibles de sufrir un impacto que no siempre podemos medir de forma objetiva, como son el valor visual-estético, el recreacional y el turístico.

En el caso del valor visual-estético, encontramos que el término unidad se utiliza a menudo en la evaluación del impacto visual para referirse al grado de coherencia y harmonía con el que se combinan todos los elementos que componen la escena (Bell, 1999) y que se relaciona, por tanto, con características físicas. Con ese mismo enfoque, también podemos relacionar el impacto estético con la perturbación visual causada por cambios en el paisaje debidos a la intervención humana, y que tienen un efecto disruptivo bien sea por su tamaño, por un estilo incongruente o por no integrarse con el entorno original (Pachaki, 2003).

Cuando analizamos la estética del paisaje no debemos olvidar que el concepto de estética deriva de teorías del diseño y relaciona descriptores del paisaje (que podríamos considerar principalmente físicos) con términos desarrollados en otros ámbitos como la filosofía, la psicología y el arte, que posteriormente se han transferido al contexto del paisaje (Tveit et al., 2006). En consecuencia, en la investigación teórica previa relacionada con la estética del paisaje encontramos estudios que intentan dar explicación a la percepción del paisaje y justificar las preferencias desde diferentes perspectivas.

Por ejemplo, en la literatura encontramos modelos teóricos en los que la percepción y la experiencia de los paisajes dependen sobre todo del bagaje cultural y de los atributos personales del observador, justificando así que la percepción estética difiere en el tiempo y en las regiones, pero también entre individuos. Estas teorías prestan más atención a las respuestas afectivas y a los atributos personales (como la edad o el género) para explicar las preferencias del paisaje (para una revisión ver Tveit et al., 2006). En esa misma línea encontramos los modelos de estética ecológica, que relacionan las preferencias del paisaje con la ética, sugiriendo que existe una predisposición por los paisajes ecológicos (Carlson, 2001).

Más recientemente, surgen enfoques de la estética del paisaje que han intentado justificar la influencia de los factores tanto culturales (aprendidos) como biológicos (innatos) para explicar las preferencias del paisaje (Bell, 1999). De este modo, las preferencias basadas en la genética se ven desafiadas por la experiencia y las influencias culturales y, por tanto, sería más apropiado hacer una síntesis de ambos puntos de vista para futuras investigaciones sobre los aspectos del paisaje a los que responden los humanos.

Finalmente, cabe mencionar un interesante enfoque que relaciona la arquitectura del paisaje con el arte, que recibe el nombre de Teoría de la Creación Estética (Zangwill, 2007). Según esta teoría, la función del arte es tener propiedades estéticas 
en virtud de ciertas propiedades no estéticas. Así, las propiedades estéticas, delineadas en función de la belleza y la fealdad como rasgos centrales, dependerían de las propiedades no estéticas (van Etteger et al., 2016).

La instalación de energías renovables es, sin duda, una intervención humana que produce un cambio significativo en el paisaje previo. En ese sentido, encontramos estudios que afirman que la apariencia visual de las instalaciones en un entorno urbano juega un papel muy importante en las preferencias del usuario final, que en este caso son los ciudadanos (Bao et al., 2017; Lu et al., 2018). En entornos rurales se ha demostrado que la percepción de plantas solares depende de la relación visual establecida entre los observadores y su entorno (Mérida-Rodríguez et al., 2015; Scognamiglio, 2016). Por tanto, independientemente de que nos encontremos en un entorno rural o urbano, resulta imperativo que se tengan en consideración los impactos visuales causados por las instalaciones de energías renovables.

\subsubsection{Factores influyentes en el impacto estético}

Según la teoría de Bishop, los aspectos cuantificables del impacto visual se dividen en tres grupos: (1) los factores relacionados con los objetos (color, tamaño, forma), los factores relacionados con el entorno (calidad visual, capacidad de absorción visual), y los factores relacionados con el observador (actividad, población expuesta). Sin embargo, esta teoría concluye que el mayor interés reside precisamente en la relación entre objeto y entorno (Bishop et al., 1990; Bishop, 1997). Para analizar esta relación parece lógico, por tanto, recurrir a factores objetivos de la propia escena que se puedan cuantificar fácilmente. Sin embargo, la influencia de los propios observadores no deberíamos subestimarla, puesto que algunos estudios muestran por ejemplo una clara influencia de la formación profesional de cada individuo con su percepción estética (Gifford et al., 2000; Naspetti et al., 2016).

La investigación en el campo de la percepción y del impacto estético es muy extensa, trabajada con imágenes, con productos o incluso con obras de arte. No obstante, cuando centramos la búsqueda en el ámbito de los sistemas de energía solar, la literatura es bastante reciente y más bien escasa. A principios de 2018 , como parte de la investigación de esta tesis, se realizó una revisión de la literatura centrada en los factores físicos que influyen en la percepción estética de los sistemas de energía solar (Sánchez-Pantoja et al., 2018). Se encontraron un total de 24 estudios, con una gran variedad de factores considerados y siendo el más antiguo de 2009. Inicialmente, los estudios consideraban solo entornos rurales, pero esta tendencia fue cambiando y en 2017 predominan los trabajos que consideraban entornos urbanos. Solo un $8 \%$ de los estudios consideraron ambos entornos. Pese a encontrar en la literatura 15 factores objetivos diferentes, algunos de ellos están muy poco presentes y no han tenido una continuidad relevante. La falta de consenso en la determinación de los factores más significativos, así como en la forma de relacionarlos, evidenciaron la necesidad de hacer una revisión teórica que permitiera 
clasificar dichos factores y estableciera unos criterios comunes basados en la literatura existente. Los datos y los resultados de dicha revisión se resumen en el capítulo 2 de esta tesis. Con posterioridad a la publicación del trabajo del capítulo 2 , se han encontrado dos publicaciones anteriores muy interesantes en las que también se trabajó la integración de los sistemas de energía solar (Munari and Roecker, 2015, 2011). En estos estudios se propone un método cualitativo para medir la integración de los SES utilizando factores objetivos (color, textura, dimensión, tipo de junta, materiales, etc.). Dicho método no define por tanto el peso de cada uno de los factores, pero si muestra coincidencias con nuestros resultados como veremos en el capítulo 5. Adicionalmente, considera aspectos muy importantes como son la sensibilidad del contexto urbano en el que se encuentra la instalación y el contexto socio-político.

En cuanto al punto de vista subjetivo de los usuarios, la escasez de datos y referencias bibliográficas en el ámbito del impacto visual de los sistemas de energía solar es aún más evidente. Encontramos en la literatura algunos estudios que han considerado la opinión y el interés por parte de los técnicos que diseñan las instalaciones y su integración (Farkas and Horvat, 2012; Munari Probst and Roecker, 2007). Sin embargo, no encontramos en la literatura estudios empíricos que tengan en cuenta la opinión de los usuarios para evaluar la percepción y el impacto visual que los sistemas de energías renovables provocan en las ciudades. De hecho, algunos trabajos recientes que incluyen aspectos relacionados con la imagen, la percepción de la ciudad o el entorno inmediato, y que tienen en cuenta a los ciudadanos (Guarachi Flores et al., 2016; Strazzera and Statzu, 2017), tampoco aciertan en ofrecer datos o factores con los que evaluar la opinión de la población en cuanto a la presencia de estas nuevas tecnologías.

Por lo que se refiere a las emociones y la propia experiencia que vive el observador, pueden servirnos de referencia aquellas investigaciones previas que señalan la valencia hedónica y la excitación emocional como las dimensiones más importantes, en relación a los significados y sentimientos connotativos cuando evaluamos reacciones emocionales frente a diferentes tipos de estímulos (Bradley et al., 2001; Mehrabian and Russell, 1974). En esta línea, y como antecedente en el ámbito del entorno arquitectónicamente construido, encontramos un único estudio que utiliza estas dos dimensiones para evaluar el impacto estético de las edificaciones (Gifford et al., 2000).

\subsubsection{Emociones y percepción estética. Aplicación a los sistemas de energía solar}

Para muchos autores una respuesta emocional comienza con la evaluación del significado personal de un evento (Lazarus, 1991; Scherer, 1984), que a su vez da lugar a una respuesta emocional compleja que se compone de una experiencia subjetiva, una reacción fisiológica y un comportamiento (Frijda, 1988; Gross, 2007; 
Lang, 1988; Larsen and Prizmic-Larsen, 2006). La revisión de la literatura relacionada con la percepción estética nos evidencia que no se trata de un proceso meramente cognitivo, sino que implica sentimientos dentro de diversos dominios como música, literatura, cine, pintura, publicidad, diseño y arquitectura (Schindler et al., 2017).

En las últimas tres décadas encontramos numerosas investigaciones interesadas en este tema. Sin embargo, psicólogos y neurocientíficos afectivos no han llegado a un consenso, ni en la definición de lo que es una emoción, ni en los elementos que deberían tenerse en cuenta para medir de forma exacta las emociones humanas. Esta falta de acuerdo es reflejo del debate abierto sobre la estructura del mundo emocional, que algunos autores prefieren explicar en términos de un número de emociones discretas y básicas, mientras que otros científicos proponen describirlo considerando unas pocas dimensiones fundamentales que organizan las respuestas emocionales.

La mayoría de los investigadores que lo explican en términos de emociones humanas adoptan generalmente un marco multinivel que incluye tres componentes: (1) una experiencia subjetiva ("feeling", etiquetado, clasificación de sentimientos), (2) unos cambios fisiológicos en cerebro y cuerpo (sudor en la palma de las manos, latidos acelerados, respiración rápida), y (3) una respuesta expresiva o de comportamiento observable (expresión facial y corporal, conductas de aproximación o evitación, lucha o huida) (Bradley and Lang, 2000). La convergencia a través de las medidas de la emoción de cada componente ha sido escasa, lo que refleja el nivel de complejidad subyacente en el mundo de las emociones (Cacioppo et al., 2000). En definitiva, las emociones no pueden ser entendidas con una medida sencilla y unitaria, pero tampoco podemos asumir como intercambiables o como medidas excluyentes de la emoción ninguno de las tres componentes que la definen: experiencia subjetiva, respuesta fisiológica y comportamiento (Mauss and Robinson, 2009).

Por otro lado, numerosos investigadores exploran la emoción humana desde una perspectiva dimensional, adoptando un marco teórico en el que las emociones se organizan básicamente en torno a dos sistemas motivacionales uno placenteroapetitivo y otro aversivo-defensivo (Lang et al., 1997). Este modelo de motivación da cuenta de los parámetros básicos de la emoción de valencia hedónica y excitación, definidos por la investigación sobre el lenguaje afectivo y el sentimiento. Así pues, los juicios sobre el placer o el desagrado indicarían qué sistema de motivación está activado (placentero-apetitivo frente a desagradable-defensivo), mientras que los juicios sobre la excitación emocional reflejarían la intensidad de la activación motivacional. Aunque estas evaluaciones subjetivas pueden estar influidas por factores personales, situacionales o culturales, la determinación biológica subyacente ha sido apoyada por un amplio número de estudios experimentales a lo largo de las tres últimas décadas. De hecho, cuando se pide a las personas que evalúen o juzguen la valencia hedónica y el nivel de activación (arousal) de una amplia gama de estímulos emocionales como imágenes, sonidos, palabras, películas 
o música, la distribución de sus juicios en el espacio afectivo bidimensional adopta un patrón de boomerang muy similar, siendo además coherente con el modelo motivacional (Bradley et al., 2001).

Considerando el ámbito de estudio de la presente tesis doctoral sobre la evaluación del impacto de los sistemas de energía renovable, cabe destacar que las emociones estéticas no vienen únicamente provocadas por las artes propiamente dichas, sino que se extienden al diseño, los entornos construidos, las edificaciones, la naturaleza y el paisaje (p. ej. (Nasar, 1992; Ulrich, 1986; Wohlwill, 1976). Por ejemplo, la exposición a la naturaleza se ha vinculado con la reducción del miedo y de la activación fisiológica, además de una mayor relajación despierta (Ulrich, 1986; Ulrich et al., 1991). Y también se ha demostrado que una mayor preferencia por entornos naturales frente a hábitats culturales construidos se explica parcialmente por la mayor restauración afectiva ofrecida por los entornos naturales (van den Berg et al., 2003).

Respecto a la percepción estética, la investigación actual muestra que necesariamente deberíamos tener en cuenta las respuestas afectivas puesto que juegan un papel muy importante para contabilizar cómo se procesan los estímulos e impactan en el observador (Schindler et al., 2017). Además, en el caso específico de los sistemas de energía solar, el uso de suelo causa un fuerte contraste en el paisaje teniendo como resultado un claro impacto visual que, en cierto modo, podría ser percibido como negativo por los ciudadanos. Hasta este punto, los investigadores han empleado principalmente medidas generales de la emoción, desarrolladas para evaluar las dimensiones básicas de la emoción en lugar de emociones específicas relacionadas con experiencias del atractivo estético de los estímulos. Como ejemplo, tenemos las "Escalas de Calidad Afectiva Atribuida a los Lugares", en las que se utilizó un cuestionario de auto-informe para evaluar la percepción estética en los entornos construidos y naturales (Galindo and Rodríguez, 2000; Russell and Pratt, 1980).

También en línea con la perspectiva dimensional, encontramos varios estudios basados en la técnica del diferencial semántico en la que los parámetros básicos para evaluar las emociones eran la valencia hedónica y la excitación (Mehrabian and Russell, 1974; Osgood, 1962). Un ejemplo es el "Self-Assessment Manikin" (conocido como SAM) que propone un instrumento de evaluación no verbal, mediante una escala gráfica que facilita la valoración de la reacción emocional sin interferencias del lenguaje (Bradley and Lang, 1994). Precisamente el capítulo 3 de esta tesis doctoral resume una investigación en la que se utilizó de forma satisfactoria este instrumento para evaluar la percepción estética de instalaciones fotovoltaicas en prototipos de vivienda solar.

El método del diferencial semántico también se ha utilizado para analizar el impacto estético que producían diferentes plantas de energía solar en personas (TorresSibille et al., 2009). Basándose en un trabajo previo, los conceptos utilizados en este 
estudio fueron afabilidad, complejidad, coherencia, amplitud afección y originalidad, siendo los términos originales en inglés "pleasantness", "complexity", "coherence", "openness", "affection" and "originality" (Küller, 1979). La investigación concluyó que una combinación de aspectos objetivos y subjetivos ayudaría a controlar mejor el impacto estético de las plantas de energía solar. Posteriormente, otro estudio consideró necesario añadir cuatro conceptos más a la lista: naturalidad (naturalness), vivacidad (liveliness), estimulación (stimulation) y grado de protección (degree of protection) (Scognamiglio, 2016).

Más recientemente, encontramos un estudio que evaluó la preferencia de sistemas de integración fotovoltaicos mediante escalas tipo Likert de 1 a 7 (Bao et al., 2017). Y también encontramos dos estudios que recogen la percepción subjetiva y la preferencia de las personas sobre sistemas fotovoltaicos, pidiendo que se clasifiquen varias imágenes según su nivel de su gusto estético subjetivo. La preferencia la midieron en este caso otorgando puntos a la clasificación (Lu et al., 2018; Naspetti et al., 2016).

En la percepción también influyen los beneficios medioambientales que se obtienen con el uso de los sistemas de energía solar, y que han sido defendidos por diferentes investigaciones tanto en entornos rurales como en entornos urbanos (Gunerhan et al., 2008; Turney and Fthenakis, 2011; Wiser et al., 2016). Esta influencia justifica que observemos una percepción generalmente positiva de estos sistemas por el hecho de ser un recurso limpio y renovable, aunque no se debe obviar en este caso la importancia de la preocupación del propio usuario por el medio ambiente, lo que podría estar sesgando los resultados (Gunerhan et al., 2008; Lu et al., 2018; Zhai and Williams, 2012). Sin embargo, debemos tener presente que también encontramos estudios que revelan ciertos aspectos negativos del uso de sistemas fotovoltaicos (Beylot et al., 2014; Chiabrando et al., 2009; Delfanti et al., 2016; Dubey et al., 2013; Hernandez et al., 2014; Rose and Wollert, 2015; Scognamiglio, 2016). En definitiva, a pesar de que la implantación de sistemas de energía solar puede causar impactos medioambientales como el uso del agua, impactos en la vida silvestre, intenso uso del suelo, ruido o emisiones nocivas, cabe resaltar que esta tecnología parece mucho más respetuosa con el medio ambiente que las fuentes de energía tradicionales (Turney and Fthenakis, 2011).

\subsubsection{Integración de energías renovables en los edificios}

La arquitectura, como disciplina, ha estado sometida en los últimos años a cambios muy significativos. Al margen de factores puramente estéticos o de diseños arquitectónicos innovadores y desafiantes, frecuentemente impulsados por arquitectos de reconocido prestigio, la construcción de edificios ha sido recientemente un importante ámbito de investigación en relación con la búsqueda de soluciones destinadas a mitigar el cambio climático. Términos como diseño bioclimático, construcción sostenible, eficiencia energética, materiales ecológicos o 
respetuosos con el medio ambiente, están asociados a los últimos avances en arquitectura que tratan de adaptarse cada vez más a un desarrollo global sostenible del sector de la construcción.

En la literatura encontramos estudios de evaluación ambiental para ayudar a los arquitectos en la selección de materiales o soluciones constructivas que garanticen la construcción de edificios con un menor impacto ambiental a lo largo de su existencia. Numerosos trabajos de investigación utilizan la metodología del Análisis del Ciclo de Vida (ACV) como herramienta de cálculo de impactos ambientales y que, por tanto, permite la comparación de diferentes aspectos abarcando desde materiales específicos a edificios enteros, incluyendo todo el proceso de obtención de materias primas, la construcción, la fase de uso e incluso el fin de vida del edificio (Azzouz et al., 2017; Bonomo et al., 2017; Hemmerle and Hemmerle, 2016; Sagani et al., 2017; Vidal et al., 2019; Zabalza et al., 2013). Debe tenerse en cuenta que los mayores impactos ambientales se producen durante la fase de uso del edificio, puesto que es la que implica un mayor consumo de energía (Ghattas et al., 2013; Peuportier, 2001; Ramesh et al., 2010), principalmente debido al uso de los sistemas de calefacción y aire acondicionado, así como los aparatos electrodomésticos y la iluminación. Está así sobradamente justificado que una parte significativa de las investigaciones se centren en reducir los impactos durante esta fase.

Una forma de reducir el impacto consiste en reducir directamente el consumo de energía del edificio, que depende de varios factores como las soluciones constructivas empleadas, las condiciones climáticas del área en la que se encuentra o el tipo de instalaciones con las que se ha equipado el edificio. Sin embargo, otra posibilidad para reducir el impacto consiste en hacer uso de energías provenientes de fuentes renovables, una opción cada vez más implementada y que se ha traducido en un incremento notable en los últimos 20 años del uso de sistemas de energía solar, tanto en España como en el resto de Europa. De hecho, las políticas europeas y mundiales establecen requisitos cada vez más exigentes en materia de sostenibilidad, y esto se traduce en una mayor presencia de instalaciones solares en el paisaje urbano, que hoy en día generan ya una fracción significativa del suministro energético europeo. Un ejemplo de ello es el Código Técnico de la Edificación en España (Gobierno de España, 2019), que obliga a la instalación de sistemas de generación de energía eléctrica procedente de fuentes renovables en edificios no residenciales y a cubrir gran parte de las necesidades de energía térmica con fuentes renovables en los edificios de uso residencial. Por tanto, hoy en día, los sistemas de mejora de la eficiencia energética -especialmente aquellos que aprovechan la energía solar por ser los más utilizados hasta el momento-, se consideran ya un elemento común del edificio.

En las últimas dos décadas, se han llevado a cabo un elevado número de investigaciones en el ámbito de la tecnología fotovoltaica. A principios del siglo XXI, ya encontramos las primeras referencias a la integración de la energía solar en los 
edificios (Krippner and Herzog, 2000). También encontramos proyectos internacionales con un claro objetivo de mejorar la integración urbana de los sistemas fotovoltaicos, como los llevados a cabo por la Agencia Internacional de la Energía (International Energy Agency, 2008, 2001). Por otro lado, la dificultad de integrar sistemas térmicos frente a los sistemas fotovoltaicos fue analizado en profundidad teniendo en cuenta el punto de vista de los arquitectos proyectistas en un estudio realizado en el proyecto SOLABS (Munari Probst and Roecker, 2007). Entrados ya en la última década, los primeros años hubo un fuerte interés por el potencial energético de las instalaciones, poniendo el foco en el aprovechamiento del área de las cubiertas de los edificios y su capacidad para albergar instalaciones fotovoltaicas. El objetivo principal de estos estudios era optimizar las instalaciones desde el punto de vista de la eficiencia energética, y con ese fin se analizaban las diferentes tecnologías existentes y su idoneidad para diferentes climatologías y entornos urbanos. Entre los ejemplos de esas investigaciones figura la revisión realizada por Makrides y sus colaboradores (Makrides et al., 2013, 2012, 2010; Vivar et al., 2014) y otros estudios que analizan los problemas de las áreas sombreadas en los entornos urbanos (D’Orazio et al., 2013; Loulas et al., 2012). Hoy en día, la mejora de la eficiencia sigue siendo un importante foco de interés en la investigación puesto que sigue existiendo posibilidad de mejora (Biyik et al., 2017).

Otro factor considerado también importante en la literatura es la repercusión del coste económico cuando se instalan sistemas fotovoltaicos para abastecer a edificios completos (Bonomo et al., 2017; Hemmerle and Hemmerle, 2016; Sagani et al., 2017; Yang and Zou, 2016). Un estudio de 2017 afirmaba que a la hora de decidir si se instala un sistema fotovoltaico en un edificio, la motivación principal del propietario es el beneficio económico personal por delante de la contribución a la protección del medio ambiente (Fleiß et al., 2017).

No podemos olvidar, sin embargo, que el uso de estas instalaciones en la envolvente del edificio está dentro del ámbito de la arquitectura. En consecuencia, no solo son importantes la eficiencia y el coste económico, sino que el aspecto estético debe considerarse también fundamental. En el ámbito de la arquitectura no es suficiente que un edificio sea funcional, puesto que la función no necesariamente determina la forma (Scruton, 2013). Por tanto, tengamos en cuenta que la aceptación de estas nuevas tecnologías por parte de los ciudadanos, como habituales usuarios de la urbe, es hoy en día un tema de creciente interés que puede suponer adicionalmente una ayuda inestimable para los técnicos en el futuro diseño de estas instalaciones. Sobre todo teniendo en cuenta que la integración de la tecnología fotovoltaica en los edificios tiene un gran potencial de aplicación si se lleva a cabo en la fase inicial de diseño del edificio (Johnston, 2007). Contrariamente, definir la instalación al final del proceso conlleva un incremento en el coste económico y un resultado estético del edificio menos atractivo. En la literatura encontramos algunos estudios que, sin analizar la percepción del usuario a nivel estético, evalúan la aceptación e incluso el deseo de adquirir o utilizar sistemas fotovoltaicos integrados en la envolvente del 
edificio (Lim et al., 2009; Radmehr et al., 2014). Estos estudios concluyen que, para conseguir la implicación de las personas en cuanto al uso de sistemas fotovoltaicos en los edificios, es necesario encontrar la forma de instalarlos sin perjudicar la estética de la fachada. Por tanto, resulta de gran interés estudiar cómo entran a formar parte de la envolvente del edificio los diferentes elementos que componen la instalación de energía solar. El análisis de cómo llevar a cabo una correcta integración de las instalaciones solares desde un punto de vista urbano ha sido investigado también en esta última década (Lobaccaro et al., 2019; Munari and Roecker, 2019, 2015, 2011).

Para la investigación de esta tesis doctoral, y centrándonos en la tecnología fotovoltaica, dependiendo de la forma en la que los sistemas de energía solar se colocan en la envolvente del edificio se han clasificado en BIPV (Building-integrated photovoltaics, sistemas totalmente integrados que conforman ellos mismos la envolvente del edificio) o BAPV (Building-applied photovoltaics, sistemas montados sobre una estructura metálica en la cubierta del edificio, sin intención de integrarlos como un elemento constructivo más de la envolvente)(ver figura 1 del capítulo 3). Para el caso de la solar térmica, encontramos en la literatura otros tipos de agrupaciones como por ejemplo los BIST (Building Integrated Solar Thermal, sistemas térmicos integrados en la envolvente del edificio), o los BAST (Building Added Solar Thermal, sistemas térmicos simplemente montados sobre la cubierta del edificio) (Farkas and Horvat, 2012; Munari Probst and Roecker, 2007).

Cuando nos referimos a los sistemas BAPV, hemos considerado instalaciones para las que la integración estética del sistema no recibe especial atención priorizándose la capacidad para captar la radiación solar que tiene el panel (orientación, grado de inclinación, etc.). El tipo de instalación y su localización, generalmente en la cubierta, se pueden decidir en un estado avanzado del proyecto o incluso a veces después de que esté terminado y, al finalizar la construcción, se obtiene un resultado menos atractivo y poco acorde al diseño arquitectónico del edificio. En cambio, en el caso de la tecnología BIPV, se requiere que el técnico proyectista considere la instalación como parte del edificio desde la fase inicial del diseño, puesto que los propios componentes del sistema son elementos constructivos de la envolvente, y se consigue así una buena integración estética en el conjunto del edificio. El uso de los sistemas BIPV está menos extendido, pero se va haciendo más popular a medida que el amplio abanico de posibilidades de integración es conocido por arquitectos y constructores (Henemann, 2008). Con esa finalidad, algunos investigadores y arquitectos dedican parte de su trabajo a exhibir el estado del arte de los productos BIPV disponibles (Cerón et al., 2013; Petter et al., 2012). En esta línea, encontramos un completo documento sobre las posibilidades de integración de la energía solar y sus características técnicas y estéticas como resultado de la IEA SHC Task 41 (Solar Heating \& Cooling Programme, 2012). Además, algunos estudios sugieren que, cuando se utilizan diseños especialmente innovadores, la integración fotovoltaica puede requerir una mayor inversión económica inicial (Athienitis and Candanedo, 
2010; Michael et al., 2010). Sin embargo, otros trabajos confirman que hay ventajas económicas a largo plazo en el uso de sistemas BIPV (Portolan dos Santos and Rüther, 2012). Aunque la implementación de estos sistemas aún es lenta, su uso ha ido en aumento en los últimos años.

Actualmente, el desarrollo tecnológico de los sistemas BIPV y su capacidad de integración en la arquitectura es un ámbito de investigación activo, tanto por parte de la comunidad científica como por parte del sector industrial fotovoltaico. Pese a que encontramos en la literatura investigaciones recientes que hacen una revisión actualizada de las posibilidades de integración de los BIPV en los edificios, debemos tener presente que aún existen importantes barreras para estos sistemas relacionadas con la eficiencia del producto y con el diseño estético (Attoye et al., 2017; Farkas and Horvat, 2012). Mirando al futuro, sería lamentable percibir dentro de 20 años que, igual que ha pasado con las instalaciones eléctricas, de telefonía o las antenas de televisión, el avance tecnológico acelerado no nos ha permitido prever y evitar el deterioro estético que puede sufrir nuestro entorno diario y nuestros edificios.

Considerando el reto social que supone este cambio en el paisaje de nuestras ciudades, debemos preguntarnos: ¿qué percepción tienen los ciudadanos de la presencia de estas instalaciones en su entorno? ¿Cómo puede el sector industrial saber si sus productos serán aceptados estéticamente o no? En la literatura no encontramos estudios que hayan tenido en cuenta la opinión de los usuarios para evaluar su percepción y el impacto visual producido en la ciudad. De hecho, recoger opiniones y datos de la sociedad de forma válida para llevar a cabo una investigación requiere tener acceso a una amplia variedad de ejemplos de sistemas de energía solar, instalados en diferentes edificios, de forma que puedan ser observados y evaluados por una muestra significativa de personas de forma anónima. Es un escenario realmente difícil de encontrar y que resultaría extraordinariamente costoso de construir con fines de investigación. No obstante, estas características se cumplen en un evento conocido mundialmente, que pone en contacto directo a la sociedad y las universidades con los últimos avances en tecnología solar para edificios residenciales. Nos referimos al Solar Decathlon (SD), celebrado por primera vez en 2002 en los EEUU y que se ha convertido, desde la segunda edición en 2005, en un importante concurso bianual e internacional para universidades. La primera versión europea de la competición (Solar Decathlon Europe, SDE) tuvo lugar en Madrid en 2010 y se repitió en la misma ciudad en 2012, antes de desplazarse a Versalles (Paris) para la exhibición de 2014. Cada edición de este concurso es un interesante muestrario de las últimas iniciativas en el ámbito de la fotovoltaica (Cronemberger et al., 2014).

Para la investigación llevada a cabo en el capítulo 3 de esta tesis, se consideró como escenario de estudio el SDE 2014, donde 20 prototipos de viviendas solares fueron sometidos durante un periodo de dos semanas a 10 pruebas para evaluar aspectos 
como el diseño arquitectónico, la eficiencia energética, la sostenibilidad, las condiciones de confort o la innovación, entre otras. En línea con el compromiso europeo de alcanzar el reto 20/20/20, el SDE estableció dos objetivos principales para las competiciones: 1) promover la innovación y la generación de conocimiento para mejorar la eficiencia energética y la sostenibilidad de los edificios y las ciudades, así como la integración de energías renovables, mediante la transferencia de conocimiento al sector industrial; y 2) utilizar todos los medios para aumentar la conciencia social frente a la importancia de utilizar energías renovables de forma responsable y construir juntos un mundo más sostenible (Vega and Rodriguez, 2014).

El trabajo llevado a cabo ofrece datos que reflejan lo que sienten los ciudadanos cuando ven las instalaciones de energía solar utilizadas en los edificios, que podrían ser parte del paisaje urbano en el que desarrollan su vida diaria. La información es de gran interés y permitirá a los investigadores continuar trabajando para mejorar futuras aplicaciones. Además de ofrecer datos recogidos directamente de los ciudadanos, la variedad de sistemas y de formas de integrar la instalación permiten hacer un análisis comparativo e incluir en el estudio sistemas BIPV y BAPV. Hay un generalizado consenso en el hecho de que el uso de tecnologías fotovoltaicas modifica la apariencia del paisaje urbano y este cambio puede ser positivo o negativo (Strazzera and Statzu, 2017). Mientras parte de la población lo ve como una oportunidad de modernizar la ciudad, otros -especialmente en barrios histórico son más críticos con estas modificaciones estéticas. En ese sentido, uno de los objetivos principales de esta tesis es identificar si estas tecnologías están bien aceptadas o no por parte de la sociedad.

\subsubsection{Transición energética e implicación europea en la aceptación social}

Asumiendo la necesidad de integrar el uso de energías renovables como parte de la lucha contra el cambio climático, la investigación ha enfatizado en los últimos años la complejidad de implementar modelos energéticos basados únicamente en sistemas de energías renovables. La principal causa es que estas energías dependen generalmente de condiciones climáticas variables como el sol o el viento y, por tanto, no es posible garantizar un suministro energético estable constante (Akinyele and Rayudu, 2014; Luo et al., 2015). No es suficiente construir plantas de energías renovables o tener una vivienda autosuficiente por medio de paneles solares. La transición energética, necesaria para reducir de forma significativa las emisiones de gases de efecto invernadero, requiere una implementación de energías renovables más ambiciosa, a escala de barrio, que incluya sistemas de almacenamiento de energía y proporcione un modelo energético de red más eficiente (GößlingReisemann et al., 2013; IRENA, 2017). Según datos de la agencia IRENA, los EEUU, China, Japón y Alemania están liderando la instalación de sistemas de almacenamiento de energía con baterías, mientras otros países como Italia o Corea del Sur les siguen de cerca (IRENA, 2015). Sin embargo, debemos tener en cuenta que algunos estudios afirman que la necesidad de contar con sistemas de almacenaje 
de energía a largo plazo podría verse modificada en el futuro a consecuencia del cambio climático (Wachsmuth et al., 2013).

Al igual que ocurrió en el ámbito de las instalaciones de energías renovables, la revisión de la literatura sugiere que la investigación relacionada con la implementación de nuevos modelos energéticos que incluyan almacenamiento a escala de barrio se enfoca inicialmente desde una perspectiva puramente técnica. El mayor interés en los sistemas de almacenamiento de energía es la optimización máxima de los recursos renovables (Akinyele and Rayudu, 2014; Amirante et al., 2017; Luo et al., 2015; Vlad et al., 2015). No obstante, en los últimos años ha habido una creciente tendencia a dar un enfoque social al trabajo de investigación y a prestar atención al impacto estético de la integración urbana de sistemas de energías renovables incluyendo los sistemas de almacenamiento que puedan llevar asociados; enfoques que hasta ahora habían sido generalmente ignorados. De hecho, los procesos de consulta, así como la integración de grupos de personas, entidades y sectores afectados en los proyectos, son altamente recomendados para conseguir la aceptación social (Wachsmuth, 2015). Encontramos una investigación reciente que establece que generalmente en este contexto se consideran tres dimensiones: de mercado, socio-política y de comunidad (Devine-Wright et al., 2017). Dicho trabajo, aborda la aceptación social de los sistemas de almacenamiento de energías renovables, pero sin incluir la evaluación del impacto estético. Y en este contexto debe tenerse en cuenta que "la aceptación puede diferenciarse empíricamente del apoyo" (Aas et al., 2014). En el caso de instalaciones a escala de edificio, algunos estudios consideran la integración de sistemas de almacenaje de energía (Basecq et al., 2013; Rempel and Rempel, 2013; Ürge-Vorsatz et al., 2015), aunque en una revisión bastante reciente se afirma que la integración formal y estética en el diseño arquitectónico aún no se ha desarrollado comercialmente (Navarro et al., 2016, 2015).

En los últimos años, la investigación ha relacionado la transición energética y la adaptación climática al concepto de resiliencia (Gleich et al., 2010; Ruth et al., 2015). Este término no se refiere a la postura de protegerse frente al cambio climático, sino que invita a un desarrollo innovador para asegurar la continuidad de los servicios a pesar de futuras incertidumbres (Wachsmuth, 2015). Sin embargo, sería recomendable entender que el término resiliencia debe incluir la aceptación estética y social, aunque aún no exista en la literatura una hoja de ruta para evaluarla. Esto además toma mayor relevancia cuando los sectores más críticos con el uso de energías renovables por los impactos medioambientales que comportan afirman que, si se abordan específicamente las desventajas del uso de tecnologías renovables, la gente las tiene en consideración en su evaluación y disminuye su aceptación (Sütterlin and Siegrist, 2017). Sabemos que las energías renovables están respaldadas en Europa por más del $80 \%$ de la población, sin embargo, no debemos olvidar que en proyectos concretos aún se encuentran casos de oposición local (Bevk and Golobič, 2020). La aparición de acciones internacionales centradas en la mejora 
de la calidad paisajística en los proyectos destinados a integrar energías renovables, permite ser optimistas de cara a una mayor consideración del impacto social que producen (COST - European Cooperation inScience and Technology, 2015).

La estrategia Marco para una Unión de la Energía resiliente (EU, 2015a) y el compromiso de la Unión Europea de convertirse en líder mundial de las energías renovables (EU, 2015b) debería traducirse en un aumento de proyectos innovadores de financiación europea destinados a la implantación real de energías renovables. Adicionalmente, también debería reflejarse en dichos proyectos europeos el creciente interés en el ámbito de la aceptación social y el impacto estético. Por todo ello, y considerando este contexto, resulta interesante analizar los proyectos de financiación europea dedicados a una implementación real en entornos urbanos de energías renovables con sistemas de almacenamiento de energía, y estudiar su relación con la evaluación de la percepción estética. Este trabajo se resume en el capítulo 4 de la presente tesis doctoral.

\subsection{Objetivos de la investigación}

El estudio del impacto estético causado por las energías renovables en la ciudad está prácticamente inexplorado en la literatura existente. Desde una perspectiva más amplia, los objetivos generales de la investigación llevada a cabo en esta tesis son, por un lado, explorar el marco conceptual que envuelve la percepción estética de los nuevos sistemas de energías renovables; y, por otro, estudiar los recursos para incrementar la aceptación social de las energías renovables en la ciudad. De esta forma, se quiere favorecer la normalización de estas instalaciones en el paisaje urbano y fomentar el uso extensivo en los nuevos edificios.

Es imprescindible tener en cuenta el importante componente social de este tema y la necesaria flexibilidad en el planteamiento de algunas fases de la investigación, dada la complejidad de diseñar una estrategia de estudio puramente cuantitativa. En este sentido, cuando trabajamos datos numéricos podemos seguir un método cuantitativo, mientras que en las fases de la investigación que requieren un enfoque más cualitativo obtenemos resultados en forma de información o descripción de situaciones, comportamientos observados o tendencias (Cadena-Iñiguez et al., 2017). Por todo ello, los objetivos marcados para esta investigación, y que se explican a continuación, son amplios y pretenden centrarse en los aspectos más importantes del ámbito de estudio.

Inicialmente, puesto que la definición de los factores objetivos que influyen en el impacto estético es confusa y no hay consenso en la literatura, un importante objetivo abordado en el capítulo 2 es identificar aquellos que son más influyentes. Además, a pesar de no constituir un objetivo propiamente dicho sino una consecuencia del análisis de los resultados de la literatura previa, la propuesta de un marco conceptual que permita facilitar el diseño de un método sistemático de 
evaluación mediante la parametrización de los factores más relevantes en futuros estudios será una aportación relevante de nuestra investigación. Estos objetivos y conclusiones se resumen en el segundo capítulo de la tesis.

A continuación, hay que tener en cuenta que los ciudadanos percibimos los beneficios medioambientales del uso de energías renovables, pero también los impactos ambientales y visuales que producen las instalaciones. Por tanto, son también objetivos de la tesis conocer si el impacto real que produce en la sociedad la integración de sistemas de energías renovables en los edificios es positivo o negativo, verificar nuestra hipótesis de partida a favor de una mayor aceptación de los sistemas BIPV frente a los BAPV y, por último, saber si hay algún parámetro sociodemográfico que influya en la percepción estética. Ligado a lo anterior, también constituye un objetivo transversal ofrecer a técnicos y sectores industriales una serie de criterios que ayuden a mejorar la aceptación de estas nuevas tecnologías en los espacios urbanos. Estos objetivos son abordados en el tercer capítulo de la tesis.

Finalmente, dado que muchos de los proyectos de investigación destinados al desarrollo y la integración de las energías renovables se realizan gracias a los programas europeos de financiación, se afrontan dos objetivos más en el cuarto capítulo. Primero, identificar cuántos proyectos llevan a cabo la implementación real de energías renovables en un entorno urbano, y posteriormente, conocer el grado de implicación reflejado en estos proyectos respecto al impacto estético que producen en la ciudad. Todo ello analizado con una perspectiva temporal y geográfica dentro del marco europeo.

En resumen, los objetivos de la investigación se enumeran a continuación:

Objetivo 1. Definir los factores objetivos más influyentes en el impacto estético de los sistemas de energía solar.

Objetivo 2.Proponer un marco metodológico cualitativo que sirva de base a futuras investigaciones.

Objetivo 3. Conocer si el impacto que producen los sistemas de energía solar utilizados en los edificios es positivo o negativo.

Objetivo 4. Demostrar una mayor aceptación por los sistemas BIPV que por los BAPV.

Objetivo 5. Identificar parámetros sociodemográficos influyentes en la percepción estética.

Objetivo 6. Cuantificar los proyectos financiados con fondos europeos que llevan a cabo la implementación real de energías renovables en un entorno urbano. 
Objetivo 7. Definir el grado de implicación de estos proyectos respecto al impacto estético que producen en la ciudad.

\subsection{Hipótesis}

Debido a la perspectiva social que tiene la investigación planteada, la presente tesis combina la formulación de hipótesis concretas con el planteamiento de tendencias y la necesidad de sanear la información previa relacionada con determinados elementos necesarios para conocer el marco conceptual que envuelve a la percepción estética de los sistemas de energías renovables.

El impacto visual está obviamente determinado por factores objetivos y subjetivos, y la investigación en este campo es extensa. Sin embargo, cuando este impacto viene provocado por sistemas de energía solar, la escasez de trabajos previos va acompañada de una falta de consenso tanto en la metodología como en los parámetros más significativos a considerar. En el caso concreto de los factores objetivos más influyentes, encontramos una amplia muestra en la literatura, aunque muchos de ellos han sido escasamente tratados, con apenas continuidad y de forma confusa, por lo que no existe un método específico que nos permita evaluar la influencia de los diferentes factores. Por tanto, es necesario llevar a cabo una revisión detallada de la información relacionada con los factores objetivos presentes en la literatura con la finalidad de entender el alcance de cada uno de ellos, así como unificar criterios que faciliten en un futuro la sistematización del proceso de evaluación y la parametrización del impacto.

En el estudio llevado a cabo en el segundo capítulo, se realizó una revisión de la literatura relacionada con el impacto estético de los sistemas de energía solar, identificando tres elementos relevantes: factores objetivos, percepción subjetiva y métodos. De esta forma, se establecieron los factores objetivos más influyentes cuando evaluamos el impacto estético de los sistemas de energía solar y se propuso un nuevo marco metodológico cualitativo que servirá de base a futuras investigaciones. El planteamiento de la hipótesis inicial a resolver en ese contexto es el siguiente:

Hipótesis 1: necesidad de revisar los factores objetivos y los criterios de evaluación ante la falta de consenso científico.

Por otro lado, los factores subjetivos relacionados con el observador también influyen en el impacto estético. En ese sentido, hay una cierta tendencia a percibir de forma positiva los sistemas de energías renovables por el hecho de ser un recurso limpio e inagotable (Gunerhan et al., 2008; Lu et al., 2018; Zhai and Williams, 2012). No obstante, también observamos detractores que revelan aspectos no tan positivos de las energías renovables, fomentando una visión menos afable de estas tecnologías (Beylot et al., 2014; Chiabrando et al., 2009; Delfanti et al., 2016; Rose 
and Wollert, 2015) o incluso encontramos estudios que, aceptando los impactos negativos que tienen el uso de estas instalaciones, defienden a largo plazo mayores beneficios que perjuicios (Turney and Fthenakis, 2011). Por tanto, es evidente que las tecnologías fotovoltaicas modifican el aspecto del entorno urbano, pero este cambio puede percibirse por parte de la sociedad como positivo o negativo (Strazzera and Statzu, 2017).

Con este escenario, mediante el análisis del impacto estético que producen los sistemas de energía solar en los edificios -desarrollado en el capítulo 3 de la tesis- se plantean las siguientes hipótesis:

Hipótesis 2: el uso de energías renovables en los edificios se percibe positivamente, además de como beneficio medioambiental, por su estética.

Hipótesis 3: los SES utilizados en los edificios tienen una mayor aceptación entre la población más joven, generalmente más receptivos a nuevas tecnologías.

Hipótesis 4: mayor aceptación de los sistemas BIPV sobre los BAPV, lo que justificaría la tolerancia del incremento de recursos económicos y técnicos necesarios cuando se opta por una adecuada integración del sistema en la envolvente del edificio, acorde al diseño arquitectónico.

Por último, en el capítulo 4 se aborda la revisión de los programas de financiación europeos considerados más relevantes en materia de promoción de las energías renovables y la mitigación del cambio climático. Partiendo de un enfoque más cualitativo, se plantean las siguientes hipótesis:

Hipótesis 5: existe una tendencia creciente de proyectos de implementación efectiva de energías renovables a escala urbana como reflejo de los compromisos y las estrategias energéticas establecidas en los últimos años por la Unión Europea (EU, 2015b, 2015a).

Hipótesis 6: escasa consideración del impacto estético en los proyectos europeos de energías renovables en entornos urbanos, pero con una tendencia al alza en los próximos años.

\subsection{Método}

Las diversas líneas de estudio abordadas en la tesis han requerido una adaptación de la metodología de trabajo a las necesidades surgidas en cada una de las diferentes fases de la investigación. A continuación, se define la metodología utilizada en cada estudio siguiendo el orden de los capítulos de la tesis. 


\subsubsection{Método utilizado para el estudio de los factores objetivos}

En este estudio, primero se llevó a cabo una revisión de la literatura relacionada con los factores objetivos o físicos que influyen en el impacto y la percepción de los sistemas de energía solar, cuyos resultados se resumen en la tabla 1 del capítulo 2. Se encontraron un total de 24 trabajos en los que se identificaron 15 factores objetivos. Sin embargo, 5 de ellos aparecieron solo en un estudio, 6 aparecieron en 2 o 3 estudios y solo 4 factores tuvieron una continuidad relevante en la literatura apareciendo en 7 o más trabajos diferentes. Algunos de los factores resultaron un poco confusos e incluso varios de ellos pueden agruparse por estar muy relacionados. De esta forma, un análisis más detallado de los factores permitió identificar los más interesantes, así como entender la relación que hay entre ellos y proponer una clasificación de estos, en función de su complejidad y de la dependencia que existe entre ellos.

Posteriormente se realizó una revisión de la literatura sobre métodos que relacionan factores objetivos con la percepción subjetiva del impacto estético de los sistemas de energía solar, más allá del uso de técnicas de validación estadística. Se encontraron 4 metodologías, algunas de las cuales podrían utilizarse para valorar el impacto estético, aunque inicialmente fueran utilizadas para determinar los factores objetivos más influyentes desde la percepción subjetiva.

Finalmente, la dificultad de comparar los factores objetivos, debido a la falta de consenso en la literatura previa, forzaron la realización de un análisis más detallado de los factores y los métodos utilizados en la literatura que, tras un profundo ejercicio de síntesis, dieron como resultado la propuesta de un marco metodológico cualitativo que servirá de punto de partida para futuras investigaciones sobre el impacto estético de los sistemas de energía solar (ver figura 1 del capítulo 2).

\subsubsection{Método aplicado en el análisis de la percepción estética subjetiva de los SES}

La investigación llevada a cabo para evaluar la percepción estética de la integración fotovoltaica en los edificios, que se expone en el capítulo 3 de esta tesis, utilizó como escenario de muestra los prototipos de viviendas solares del concurso Solar Decathlon Europe 2014 celebrado en Versalles. El estudio tiene como novedad recoger datos directamente de los ciudadanos sobre sus sentimientos cuando observan los prototipos. Para ello, se realizó una encuesta, en la que se evaluaron 20 prototipos, con una variada muestra de tecnologías de energía solar incluyendo sistemas BIPV y BAPV (ver figura 3 del capítulo 3 ).

Debido a la corta duración del evento, dos semanas de apertura al público, se realizaron encuestas de forma presencial en Versalles y posteriormente encuestas "online" mediante el uso de fotografías, consiguiendo así una muestra significativa 
que diera consistencia a los resultados. El análisis estadístico de los datos obtenidos permitió, en primer lugar, justificar la validez ecológica de los datos obtenidos mediante fotografías. En segundo lugar, evaluar si la percepción estética de los encuestados era positiva o negativa, así como el grado de activación emocional que experimentaron. En tercer lugar, comparar los resultados obtenidos por las tecnologías BIPV y BAPV; y, por último, analizar posibles influencias de las variables sociodemográficas consideradas.

La estructura de la encuesta consistió en una primera parte destinada a obtener datos genéricos descriptivos del perfil de los encuestados y una segunda parte dedicada a la recogida de datos sobre sus sentimientos mientras observaban los prototipos. Los datos sobre el perfil genérico incluyeron parámetros como la edad, el género, el nivel de educación, si tiene formación relacionada con la arquitectura, el grado de preocupación por el medioambiente y el tipo de entorno en el que vive (ciudad grande, pequeña o área rural). Para la recogida de datos sobre las emociones subjetivas de los encuestados se utilizó el método SAM (maniquí de autoevaluación). EI SAM es un instrumento no verbal que incluye una escala pictórica para evaluar las reacciones emocionales, facilitando así la obtención de datos en un entorno multicultural como el SDE (ver figura 4 del capítulo 4). Mediante estos pictogramas, con una escala de valores del 1 al 7, se evaluaron dos dimensiones: la valencia hedónica (agrado-desagrado) y la activación emocional (o grado de excitación). A las personas encuestadas se les solicitó que marcaran la figura cuya expresión se identificara mejor con sus sentimientos al observar cada prototipo.

\subsubsection{Metodología utilizada en el análisis de la implicación europea}

El capítulo 4 expone el trabajo realizado para estudiar, dentro del contexto europeo, la implicación real de las instituciones en el fomento de una instalación efectiva de energías renovables a escala urbana, es decir de barrio, así como el grado de concienciación respecto al impacto estético que este tipo de proyectos provocan. La metodología utilizada para llevar a cabo una revisión sistemática de los proyectos realizados con financiación europea, que puede verse resumida de forma gráfica en la figura 1 del capítulo 4, se desarrolló en dos fases consecutivas. En la primera, se realizó una búsqueda de proyectos europeos aplicando una serie de filtros en tres pasos sucesivos con la finalidad de seleccionar solo aquellos que cumplían con los criterios de inclusión del estudio. En la segunda fase, se obtuvo información adicional mediante una encuesta electrónica basada en un cuestionario validado y diseñado exclusivamente para esta investigación con la ayuda de un grupo de expertos de la Universitat Politècnica de València.

Para la primera fase, la búsqueda online incluyó los proyectos de los 5 programas de financiación europeos más relevantes en relación con la promoción de energías renovables y la mitigación del cambio climático, siendo estos: Interreg, Climate-KIC, Life, FP7 y H2020. Los proyectos destinados a mejoras de la red energética, aquellos 
localizados en entornos rurales o en el mar, así como proyectos en los que la energía estaba destinada a movilidad o edificios específicos (autoconsumo), fueron excluidos del estudio. Se revisaron por completo todos los proyectos escritos en inglés, español, alemán, francés, italiano y portugués, mientras que solo se chequearon palabras clave en aquellos escritos en otras lenguas como polaco, checo o croata.

El primer filtrado consistió en la búsqueda para cada uno de los 5 programas utilizando palabras clave (renewable energies, urban energy storage systems, energy transition, cities development), así como temas ("low-carbon economy", "combating climate change" y "environment and resource efficiency") y filtros adicionales ("Energy" para los programas FP7 y H2020). Sumando los 5 programas, se revisaron un total de 13989 proyectos en este primer filtrado.

En el segundo filtrado, se revisó el título y el resumen de todos los proyectos localizados mediante el paso anterior, con la finalidad de identificar aquellos relacionados con la implementación de energías renovables a escala urbana (entendiendo como tal, aquella que de una única instalación abastece a varios edificios). Como resultado se identificaron 38 proyectos del programa Interreg, 11 del FP7-Energy y 17 del H2O2O.

El tercer filtrado consistió en consultar la página web de estos 66 proyectos para confirmar que la finalidad del proyecto era la implantación real de una o varias instalaciones de energía renovable a escala urbana. Finalmente, solo 16 proyectos fueron seleccionados para pasar a la segunda fase, habiéndose descartado muchos proyectos principalmente por estar destinados a la implementación de estrategias, políticas o concienciación, por estar destinados únicamente a instalaciones térmicas sin ningún impacto estético en la ciudad o por tratarse de instalaciones en edificios puntuales sin integración urbana entre otras razones.

La segunda fase del estudio consistió en la obtención de datos a través de una encuesta online en la que se solicitaba información sobre las características de las instalaciones implementadas, así como el tipo de sistemas de energías renovables y de almacenaje de energía que se utilizaban. Este proceso resultó complejo debido a que prácticamente el $70 \%$ de los proyectos todavía no se habían completado en ese momento, dificultando que las entidades proporcionaran datos relevantes. Finalmente, se obtuvo información relevante de un total de seis proyectos europeos, incluyendo siete distritos como demostradores reales.

\subsection{Estructura de la tesis}

La presente tesis doctoral, organizada conforme al estilo por compendio de artículos, aborda un tema poco tratado en la literatura, pero de creciente interés como es la percepción estética de los sistemas de energías renovables integrados en el entorno urbano. Por ese motivo, se abren varias líneas de investigación relevantes 
relacionadas con el tema central, el "impacto estético", que se ven reflejadas en los diferentes capítulos que la forman.

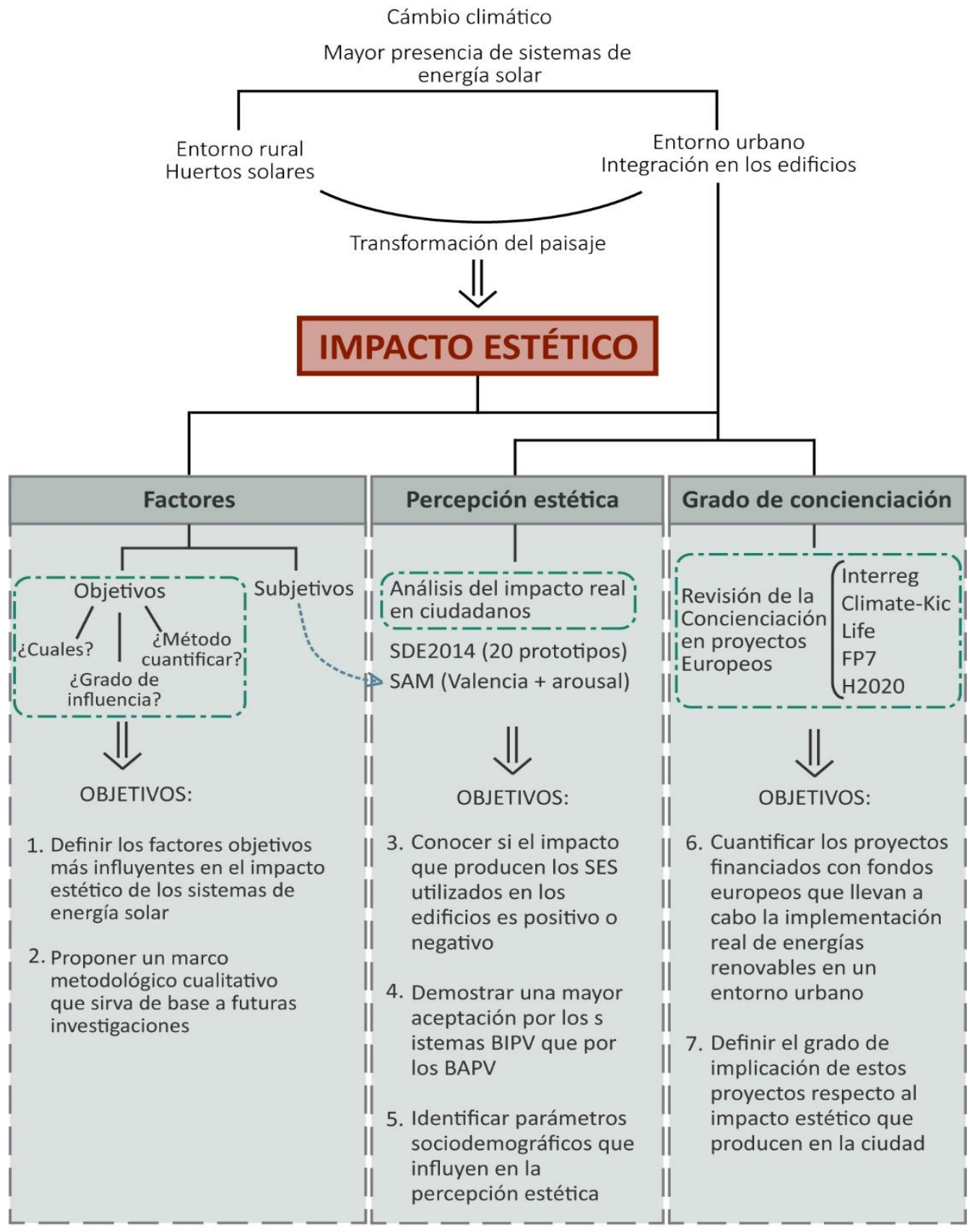

Fig. 1. 1 Organización de la investigación de la tesis

La Fig. 1.1 resume gráficamente la estructura que ha seguido la investigación. El foco principal de la tesis es el impacto estético, que viene derivado de la paulatina transformación del paisaje que están sufriendo nuestras ciudades y que ya ha sufrido 
con antelación el paisaje rural. Todo ello acelerado por los cambios en las demandas de las políticas energéticas y edificatorias de la última década, que exigen el uso de energías renovables y se traducen en una mayor presencia de sistemas de energía solar para el funcionamiento de los edificios. Esta transformación se entiende necesaria para reducir las emisiones de gases de efecto invernadero y, por consiguiente, los efectos dañinos del cambio climático.

Centrando la atención sobre todo en el entorno urbano, menos explorado en la literatura, las diferentes líneas de investigación abordadas se identifican con cada uno de los artículos publicados. De esta forma, el conjunto de la tesis ofrece un marco teórico y conceptual entorno a la percepción estética de las instalaciones de energía solar, que engloba los aspectos más relevantes para tener en cuenta en la evaluación del impacto estético.

La primera línea de investigación, capítulo 2 de la tesis, se centra en el impacto estético de las instalaciones de energía solar desde un punto de vista objetivo. Se lleva a cabo una revisión de los factores más influyentes en la percepción estética, así como de los métodos que relacionan los factores objetivos con la percepción subjetiva del impacto estético de los sistemas de energía solar, llegando finalmente a proponer un marco metodológico cualitativo que pueda servir de base para futuras investigaciones.

En el capítulo 3, se presenta un estudio que aborda la percepción estética desde un punto de vista subjetivo, centrando la atención en la evaluación del impacto real que causan estas instalaciones en los ciudadanos. Para ello, se recogieron datos por medio de una encuesta que permitieron, mediante un análisis estadístico, evaluar la percepción estética de los ciudadanos utilizando los parámetros de valencia hedónica y excitación (arousal). El escenario utilizado como modelo fue la exposición del concurso internacional Solar Decathlon Europe, con 20 prototipos de viviendas solares, que incluían tanto sistemas BIPV como BAPV. Como resultado se muestran datos sobre las preferencias de los usuarios, así como la influencia de las variables sociodemográficas consideradas.

Por último, el estudio del capítulo 4 supone una perspectiva diferente que se abstrae del impacto de la propia instalación. La investigación toma un enfoque de carácter cualitativo que, desde una perspectiva social y genérica más amplia, analiza el grado de concienciación y preocupación que tienen los proyectos europeos y entidades implicadas en el impacto estético que provocan y que hemos visto en los capítulos anteriores que emerge como foco de interés en la literatura. Con este fin, se realizó una revisión detallada de los 5 programas de financiación europea más relacionados con el fomento de las energías renovables y la mitigación del cambio climático. Finalmente, el volumen de información analizada sirve de base para una extensa discusión de los resultados, teniendo en cuenta circunstancias como la evolución temporal, el marco político y geográfico, así como los aspectos estéticos. 
En el capítulo 5 se realiza una discusión que pretende destacar los resultados y objetivos alcanzados en la tesis, abordando las diversas líneas de investigación tratadas e ilustrando las relaciones entre ellas, así como con estudios previos. Adicionalmente, se sugieren líneas de investigación futuras y se señalan las limitaciones de la tesis, terminando con un apartado dedicado a mostrar la repercusión que esta investigación puede tener en la sociedad y en el proceso de integración de sistemas de energía solar en las ciudades.

Finalmente, las conclusiones más relevantes de la tesis se exponen de forma resumida en el capítulo 6.

\section{REFERENCIAS}

Aas, $\varnothing$., Devine-Wright, P., Tangeland, T., Batel, S., Ruud, A., 2014. Public beliefs about highvoltage powerlines in Norway, Sweden and the United Kingdom: A comparative survey. Energy Res. Soc. Sci. 2, 30-37. https://doi.org/10/drwp

Akinyele, D.O., Rayudu, R.K., 2014. Review of energy storage technologies for sustainable power networks. Sustain. Energy Technol. Assessments 8, 74-91. https://doi.org/10/drwr

Amirante, R., Cassone, E., Distaso, E., Tamburrano, P., 2017. Overview on recent developments in energy storage: Mechanical, electrochemical and hydrogen technologies. Energy Convers. Manag. https://doi.org/10/drws

Athienitis, A.K., Candanedo, J.A., 2010. Building integration of photovoltaic systems in cold climates, in: Photonics North 2010. https://doi.org/10/bhxv9x

Attoye, D.E., Aoul, K.A.T., Hassan, A., 2017. A review on building integrated photovoltaic façade customization potentials. Sustain. 9. https://doi.org/10/gcvb5z

Azzouz, A., Borchers, M., Moreira, J., Mavrogianni, A., 2017. Life cycle assessment of energy conservation measures during early stage office building design: A case study in London, UK. Energy Build. 139, 547-568. https://doi.org/10/f9zsqz

Bao, Q., Honda, T., El Ferik, S., Shaukat, M.M., Yang, M.C., 2017. Understanding the role of visual appeal in consumer preference for residential solar panels. Renew. Energy 113, 1569-1579. https://doi.org/10/drwt

Basecq, V., Michaux, G., Inard, C., Blondeau, P., 2013. Short-term storage systems of thermal energy for buildings: a review. Adv. Build. Energy Res. 7, 66-119. https://doi.org/10/drwv

Bell, S., 1999. Landscape: Pattern, Perception and Process, First. ed. London: E\&FN Spon, Oxon.

Bevk, T., Golobič, M., 2020. Contentious eye-catchers: Perceptions of landscapes changed by solar power plants in Slovenia. Renew. Energy 152, 999-1010. https://doi.org/10/drww 
Beylot, A., Payet, J.Ô., Puech, C., Adra, N., Jacquin, P., Blanc, I., Beloin-Saint-Pierre, D., 2014. Environmental impacts of large-scale grid-connected ground-mounted $\mathrm{PV}$ installations. Renew. Energy 61, 2-6. https://doi.org/10/drwx

Bishop, I., Dartnell, P., Davie, S., Drew, J., McDonald, T., 1990. Object, environment and observer related variables in the visual effect of electricity transmission lines. Landsc. Aust.

Bishop, I.D., 1997. Testing perceived landscape colour difference using the Internet. Landsc. Urban Plan. 37, 187-196. https://doi.org/10/djhmvj

Biyik, E., Araz, M., Hepbasli, A., Shahrestani, M., Yao, R., Shao, L., Essah, E., Oliveira, A.C., del Caño, T., Rico, E., Lechón, J.L., Andrade, L., Mendes, A., Atlı, Y.B., 2017. A key review of building integrated photovoltaic (BIPV) systems. Eng. Sci. Technol. an Int. J. 20, 833858. https://doi.org/10/gd2z9k

Bonomo, P., Frontini, F., De Berardinis, P., Donsante, I., 2017. BIPV: building envelope solutions in a multi-criteria approach. A method for assessing life-cycle costs in the early design phase. Adv. Build. Energy Res. 11, 104-129. https://doi.org/10/drwz

Bradley, M.M., Codispoti, M., Cuthbert, B.N., Lang, P.J., 2001. Emotion and motivation I: defensive and appetitive reactions in picture processing. Emotion 1, 300-319. https://doi.org/10/d7tq64

Bradley, M.M., Lang, P.J., 2000. Measuring emotion: Behavior, feeling, and physiology, in: Cognitive Neuroscience of Emotion. Oxford.

Bradley, M.M., Lang, P.J., 1994. Measuring emotion: The self-assessment manikin and the semantic differential. J. Behav. Ther. Exp. Psychiatry 25, 49-59. https://doi.org/10/bx59sf

Cacioppo, J.T., Berntson, G., Larsen, J., Poehlmann, K.M., Ito, T.A., 2000. The Psychophysiology of Emotion, in: The Handbook of Emotion. New York: Guilford Press., pp. 173-191.

Cadena-Iñiguez, P., Rendón-Medel, R., Aguilar-Ávila, J., Salinas- Cruz, E., De la Cruz-Morales, F.D.R., Sangerman-Jarquín, D.M., 2017. Métodos cuantitativos, métodos cualitativos o su combinación en la investigación: un acercamiento en las ciencias sociales. Rev. Mex. Ciencias Agrícolas 8, 1603-1617. https://doi.org/10/drw2

Carlson, A., 2001. Aesthetic preferences for sustainable landscapes: seeing and knowing. For. Landscapes. New York CABI Publ. 31-42.

Cerón, I., Caamaño-Martín, E., Neila, F.J., 2013. 'State-of-the-art' of building integrated photovoltaic products. Renew. Energy 58, 127-133. https://doi.org/10/drw3

Chiabrando, R., Fabrizio, E., Garnero, G., 2009. The territorial and landscape impacts of photovoltaic systems: Definition of impacts and assessment of the glare risk. Renew. Sustain. Energy Rev. 13, 2441-2451. https://doi.org/10/fb3464 
COST - European Cooperation inScience and Technology, 2015. Cost Rely Action - Renewable Energy and Landscape Quality [WWW Document]. URL http://costrely.eu/activities/cost-meeting (accessed 9.12.20).

Cronemberger, J., Corpas, M.A., Cerón, I., Caamaño-Martín, E., Sánchez, S.V., 2014. BIPV technology application: Highlighting advances, tendencies and solutions through Solar Decathlon Europe houses. Energy Build. 83, 44-56. https://doi.org/10/drw5

D’Orazio, M., Di Perna, C., Di Giuseppe, E., 2013. Performance assessment of different roof integrated photovoltaic modules under Mediterranean Climate. Energy Procedia 42, 183-192. https://doi.org/10/drw6

Daniel, T.C., 2001. Whither scenic beauty? Visual landscape quality assessment in the 21st century. Landsc. Urban Plan. 54, 267-281. https://doi.org/10/fbwznr

Delfanti, L., Colantoni, A., Recanatesi, F., Bencardino, M., Sateriano, A., Zambon, I., Salvati, L., 2016. Solar plants, environmental degradation and local socioeconomic contexts: A case study in a Mediterranean country. Environ. Impact Assess. Rev. 61, 88-93. https://doi.org/10/drw7

Devine-Wright, P., Batel, S., Aas, O., Sovacool, B., Labelle, M.C., Ruud, A., 2017. A conceptual framework for understanding the social acceptance of energy infrastructure: Insights from energy storage. Energy Policy 107, 27-31. https://doi.org/10/gbpts8

Dubey, S., Jadhav, N.Y., Zakirova, B., 2013. Socio-economic and environmental impacts of silicon based photovoltaic (PV) technologies. Energy Procedia 33, 322-334. https://doi.org/10/drw8

EU, 2015a. Estrategia Marco para una Unión de la Energía resiliente con una política climática prospectiva. Brusels.

EU, 2015b. Energy Union Package.

EU, 2014. Establishing Horizon 2020 - The framework programme for research and innovation (2014-2020).

EU, 2010a. EUROPE 2020 A strategy for smart, sustainable and inclusive growth.

EU, 2010b. Directive 2010/35/EU, Official Journal of the European Union.

EU, 2009. Directiva 2009/28/CE, Official Journal of the European Union.

EU, 2003. Directiva 2002/91/CE, Official Journal of the European Union.

EU, 2000. European Landscape Convention (No. ETS no. 176).

Farkas, K., Horvat, M., 2012. Report T.41.A.1: Building integration of Solar Thermal and Photovoltaics: barriers, needs, strategies.

Fleiß, E., Hatzl, S., Seebauer, S., Posch, A., 2017. Money, not morale: The impact of desires 
and beliefs on private investment in photovoltaic citizen participation initiatives. J. Clean. Prod. 141, 920-927. https://doi.org/10/f9fbjz

Frijda, N.H., 1988. The laws of emotion. Am. Psychol. 43, 349-358. https://doi.org/10/ckq

Galindo, M., Rodríguez, J., 2000. Environmental aesthetics and psychological wellbeing: relationships between preference judgements for urban landscapes and other relevant affective responses. Psychol. Spain 4, 13-27.

Ghattas, R., Gregory, J., Olivetti, E., Greene, S., 2013. Life Cycle Assessment for Residential Buildings : A Literature Review and Gap Analysis 1-21.

Gifford, R., Hine, D.W., Muller-Clemm, W., D’Arcy J Reynolds, J., Shaw, K.T., 2000. Decoding modern architecture. A lens model approach for understanding the aesthetic differences of architects and laypersons. Environ. Behav. 32, 163-187.

Gleich, A. von, Gößling-Reisemann, S., Stührmann, S., Woizeschke, P., Lutz-Kunisch, B., 2010. Resilienz als Leitkonzept-vulnerabilität als analytische Kategorie. Theor. Grundlagen für erfolgreiche Klimaanpassungsstrategien. Bremen, Proj. Nord. 13-49.

Gobierno de España, 2019. Documento Básico HE Ahorro de Energía, Código técnico de la Edificación, Documento básico HE ahorro de energía.

Gößling-Reisemann, S., Wachsmuth, J., Stührmann, S., von Gleich, A., 2013. Climate change and structural vulnerability of a metropolitan energy system: The case of BremenOldenburg in Northwest Germany. J. Ind. Ecol. 17, 846-858. https://doi.org/10/f5knwr

Gross, J.J., 2007. Handbook of emotion regulation. Guilford Press, New York.

Guarachi Flores, J., García, R., Jofré, J., 2016. Integración arquitectónica de la fachada fotovoltaica. Potencial solar y percepción de usuario en la vivienda colectiva. Arquit. y Urban. XXXVII, 33-48.

Gunerhan, H., Hepbasli, A., Giresunlu, U., 2008. Environmental impacts from the solar energy systems. Energy Sources, Part A Recover. Util. Environ. Eff. 31, 131-138. https://doi.org/10/fpvvss

Hemmerle, C., Hemmerle, C., 2016. Solar PV building skins: Structural requirements and environmental benefits. J. Facade Des. Eng. 5, 93-105. https://doi.org/10/drw9

Henemann, A., 2008. BIPV: Built-in solar energy. Renew. Energy Focus 9, 14,16-19. https://doi.org/10/fq5hr6

Hernandez, R.R., Easter, S.B., Murphy-Mariscal, M.L., Maestre, F.T., Tavassoli, M., et al., 2014. Environmental impacts of utility-scale solar energy. Renew. Sustain. Energy Rev. https://doi.org/10/f5ps68

International Energy Agency, 2008. IEA PVPS Task 10 [WWW Document]. URL https://ieapvps.org/research-tasks/urban-scale-grid-connected-pv-applications/ 
International Energy Agency, 2001. IEA PVPS Task 7 [WWW Document]. URL https://ieapvps.org/research-tasks/photovoltaic-power-systems-in-the-built-environment/ (accessed 9.12.20).

IRENA, 2017. Electricity storage and renewables: Costs and markets to 2030, International Renewable Energy Agency. Abu Dhabi.

IRENA, 2015. Battery storage for renewables: Market status and technology outlook, International Renewable Energy Agency.

Johnston, D., 2007. Solar energy systems installed on Chinese-style buildings. Energy Build. 39, 385-392. https://doi.org/10/fg5t7c

Koellner, T., de Baan, L., Beck, T., Brandão, M., Civit, B., et al., 2013. UNEP-SETAC guideline on global land use impact assessment on biodiversity and ecosystem services in LCA. Int. J. Life Cycle Assess. 18, 1188-1202. https://doi.org/10/f3p7h4

Krippner, R., Herzog, T., 2000. Architectural aspects of solar techniques. Studies on the integration of solar energy systems into the building skin, in: Proceedings Eurosun 2000.

Küller, R., 1979. A semantic test for use in cross-cultural studies. Man-Environment Syst. 9, 253-256.

Lang, P.J., 1988. What are the data of emotion?, in: Hamilton, V., Bower, G.H., Frijda, N.H. (Eds.), Cognitive Perspectives on Emotion and Motivation. Kluwer Academic Publishers, Dordrecht, pp. 173-191. https://doi.org/10/drxb

Lang, P.J., Bradley, M.M., Cuthbert, B.N., 1997. Motivated attention: Affect, activation, and action., in: Attention and Orienting : Sensory and Motivational Processes. Lawrence Erlbaum Associates, pp. 97-135.

Larsen, R.J., Prizmic-Larsen, Z., 2006. Measuring emotions: Implications of a multimethod perspective., in: Handbook of Multimethod Measurement in Psychology. American Psychological Association, Washington, pp. 337-351. https://doi.org/10/b9xc5j

Lazarus, R.S., 1991. Emotion and adaptation. Oxford University Press, Oxford.

Lim, C.H., Sopian, K., Sulaiman, Y., Ruslan, M.H., Yahya, M., 2009. Assessment of public perception on photovoltaic application in Malaysia urban residential areas using Trudgill's framework for analysis. Eur. J. Soc. Sci. 8, 589-603.

Lindeijer, E., 2000. Review of land use impact methodologies. J. Clean. Prod. 8, 273-281. https://doi.org/10/d4jmp5

Lobaccaro, G., Croce, S., Lindkvist, C., Munari, M.C., Scognamiglio, A., Dahlberg, J., Lundgren, M., Wall, M., 2019. A cross-country perspective on solar energy in urban planning: Lessons learned from international case studies. Renew. Sustain. Energy Rev. 108, 209237. https://doi.org/10/dsfs 
Lothian, A., 1999. Landscape and the philosophy of aesthetics: is landscape quality inherent in the landscape or in the eye of the beholder? Landsc. Urban Plan. 44, 177-198. https://doi.org/10/bzszrz

Loulas, N.M., Karteris, M.M., Pilavachi, P.A., Papadopoulos, A.M., 2012. Photovoltaics in urban environment: A case study for typical apartment buildings in Greece. Renew. Energy 48, 453-463. https://doi.org/10/drxc

Lu, M., Lin, A., Sun, J., 2018. The impact of photovoltaic applications on urban landscapes based on visual Q methodology. Sustainability 10, 1-15. https://doi.org/10/gdr52n

Luo, X., Wang, J., Dooner, M., Clarke, J., 2015. Overview of current development in electrical energy storage technologies and the application potential in power system operation. Appl. Energy 137, 511-536. https://doi.org/10/f6w3hg

Makrides, G., Zinsser, B., Norton, M., Georghiou, G.E., Schubert, M., Werner, J.H., 2010. Potential of photovoltaic systems in countries with high solar irradiation. Renew. Sustain. Energy Rev. 14, 754-762. https://doi.org/10/b8r4pt

Makrides, G., Zinsser, B., Phinikarides, A., Schubert, M., Georghiou, G.E., 2012. Temperature and thermal annealing effects on different photovoltaic technologies. Renew. Energy 43, 407-417. https://doi.org/10/fzs84s

Makrides, G., Zinsser, B., Schubert, M., Georghiou, G.E., 2013. Seasonal performance comparison of different photovoltaic technologies installed in Cyprus and Germany. Int. J. Sustain. Energy 32, 466-488. https://doi.org/10/drxd

Mauss, I.B., Robinson, M.D., 2009. Measures of emotion: A review. Cogn. Emot. 23, 209-237. https://doi.org/10/fj2s3g

Mehrabian, A., Russell, J.A., 1974. An approach to environmental psychology, Cambridge Mass The MIT Press.

Mérida-Rodríguez, M., Lobón-Martín, R., Perles-Roselló, M., 2015. The production of solar photovoltaic power and its landscape dimension, in: Renewable Energies and European Landscapes. Springer Netherlands, Dordrecht, pp. 255-277. https://doi.org/10/drxf

Michael, A., Bougiatioti, F., Oikonomou, A., 2010. Less could be more: architectural integration of active solar systems in existing urban centres, in: 7th Mediterranean Conference and Exhibition on Power Generation, Transmission, Distribution and Energy Conversion (MedPower 2010). IET, pp. 189-189. https://doi.org/10/ftr565

Munari, M.C., Roecker, C., 2019. Criteria and policies to master the visual impact of solar systems in urban environments: The LESO-QSV method. Sol. Energy 184, 672-687. https://doi.org/10/dvsh

Munari, M.C., Roecker, C., 2015. Solar energy promotion \& urban context protection : LESOQSV (Quality-Site-Visibility)method, in: 31th International PLEA Conference.

Munari, M.C., Roecker, C., 2011. Urban acceptability of building integrated solar systems: 
LESO-QSV approach, in: 30th ISES Biennial Solar World Congress. pp. 4359-4367. https://doi.org/10.18086/swc.2011.27.10

Munari Probst, M.C., Roecker, C., 2007. Towards an improved architectural quality of building integrated solar thermal systems (BIST). Sol. Energy 81, 1104-1116. https://doi.org/10.1016/j.solener.2007.02.009

Nasar, J.L., 1992. Environmental aesthetics: Theory, research, and application. Cambridge University Press.

Naspetti, S., Mandolesi, S., Zanoli, R., 2016. Using visual Q sorting to determine the impact of photovoltaic applications on the landscape. Land use policy 57, 564-573. https://doi.org/10/drxg

Navarro, L., de Gracia, A., Colclough, S., Browne, M., McCormack, S.J., et al., 2016. Thermal energy storage in building integrated thermal systems: A review. Part 1. active storage systems. Renew. Energy. https://doi.org/10/drxh

Navarro, L., de Gracia, A., Niall, D., Castell, A., Browne, M., et al., 2015. Thermal energy storage in building integrated thermal systems: A review. Part 2. Integration as passive system. Renew. Energy. https://doi.org/10/drxj

Osgood, C.E., 1962. Studies on the generality of affective meaning systems. Am. Psychol. 17, 10-28. https://doi.org/10/c4vj88

Pachaki, C., 2003. Agricultural landscape indicators: a suggested approach for the scenic value., in: Dramstad, W., Sogge, C. (Eds.), OCDE, Agricultural Impacts on Landscapes: Developing Indicators for Policy Analysis. pp. 240-250.

Petter, B., Breivik, C., Drolsum, H., 2012. Building integrated photovoltaic products: A stateof-the-art review and future research opportunities. Sol. Energy Mater. Sol. Cells 100, 69-96. https://doi.org/10/drxr

Peuportier, B.L.., 2001. Life cycle assessment applied to the comparative evaluation of single family houses in the French context. Energy Build. 33, 443-450. https://doi.org/10/bx6tjv

Plieninger, T., Kizos, T., Bieling, C., Dû-Blayo, L. Le, Budniok, M.-A., et al., 2015. Exploring ecosystem-change and society through a landscape lens: recent progress in European landscape research. Ecol. Soc. 20 (2). https://doi.org/10/f3nc5p

Portolan dos Santos, Í., Rüther, R., 2012. The potential of building-integrated (BIPV) and building-applied photovoltaics (BAPV) in single-family, urban residences at low latitudes in Brazil. Energy Build. 50, 290-297. https://doi.org/10/drxt

Radmehr, M., Willis, K., Kenechi, U.E., 2014. A framework for evaluating WTP for BIPV in residential housing design in developing countries: A case study of North Cyprus. Energy Policy 70, 207-216. https://doi.org/10/drxv

Ramesh, T., Prakash, R., Shukla, K.K., 2010. Life cycle energy analysis of buildings: An 
overview. Energy Build. 42, 1592-1600.

Rempel, A.R., Rempel, A.W., 2013. Rocks, clays, water, and salts: Highly durable, infinitely rechargeable, eminently controllable thermal batteries for buildings, Geosciences. https://doi.org/10/gcfpq9

Rose, T., Wollert, A., 2015. The dark side of photovoltaic - 3D simulation of glare assessing risk and discomfort. Environ. Impact Assess. Rev. 52, 24-30. https://doi.org/10/f664v6

Russell, J.A., Pratt, G., 1980. A description of the affective quality attributed to environments. J. Pers. Soc. Psychol. 38, 311-322. https://doi.org/10/d33dqm

Ruth, M., Özgün, O., Wachsmuth, J., Gößling-Reisemann, S., 2015. Dynamics of energy transitions under changing socioeconomic, technological and climate conditions in Northwest Germany. Ecol. Econ. 111, 29-47. https://doi.org/10/f65cpz

Sagani, A., Mihelis, J., Dedoussis, V., 2017. Techno-economic analysis and life-cycle environmental impacts of small-scale building-integrated PV systems in Greece. Energy Build. 139, 277-290. https://doi.org/10/f9ztx4

Sánchez-Pantoja, N., Vidal, R., Pastor, M.C., 2018. Aesthetic impact of solar energy systems. Renew. Sustain. Energy Rev. 98, 227-238. https://doi.org/10/gfqh7s

Scherer, K.R., 1984. Emotion as a multicomponent process: A model and some cross-cultural data. Rev. Personal. Soc. Psychol. 5, 37-63.

Schindler, I., Hosoya, G., Menninghaus, W., Beermann, U., Wagner, V., Eid, M., Scherer, K.R., 2017. Measuring aesthetic emotions: A review of the literature and a new assessment tool. PLoS One 12. https://doi.org/10/gbgrn5

Scognamiglio, A., 2016. "Photovoltaic landscapes": Design and assessment. A critical review for a new transdisciplinary design vision. Renew. Sustain. Energy Rev. 55, 629-661. https://doi.org/10/drxw

Scruton, R., 2013. The aesthetics of architecture. Princeton University Press.

Solar Heating \& Cooling Programme, 2012. Report T.41.A.2: Solar energy systems in architecture.

Strazzera, E., Statzu, V., 2017. Fostering photovoltaic technologies in Mediterranean cities: Consumers' demand and social acceptance. Renew. Energy 102, 361-371. https://doi.org/10/f9hmhh

Sütterlin, B., Siegrist, M., 2017. Public acceptance of renewable energy technologies from an abstract versus concrete perspective and the positive imagery of solar power. Energy Policy 106, 356-366. https://doi.org/10/gbhj4r

Torres-Sibille, A.C., Cloquell-Ballester, Vicente-A., Cloquell-Ballester, Víctor-A., Artacho, M.A., 2009. Aesthetic impact assessment of solar power plants: An objective and a subjective approach. Renew. Sustain. Energy Rev. 13, 986-999. https://doi.org/10/c4xh7r 
Turney, D., Fthenakis, V., 2011. Environmental impacts from the installation and operation of large-scale solar power plants. Renew. Sustain. Energy Rev. 15, 3261-3270. https://doi.org/10/cxxbqb

Tveit, M., Ode, Å., Fry, G., 2006. Key concepts in a framework for analysing visual landscape character. Landsc. Res. 31, 229-255. https://doi.org/10/b7pvxd

Ulrich, R.S., 1986. Human responses to vegetation and landscapes. Landsc. Urban Plan. 13, 29-44. https://doi.org/10/drs775

Ulrich, R.S., Simons, R.F., Losito, B.D., Fiorito, E., Miles, M.A., Zelson, M., 1991. Stress recovery during exposure to natural and urban environments. J. Environ. Psychol. 11, 201-230. https://doi.org/10/csp47k

Ürge-Vorsatz, D., Cabeza, L.F., Serrano, S., Barreneche, C., Petrichenko, K., 2015. Heating and cooling energy trends and drivers in buildings. Renew. Sustain. Energy Rev. 41, 85-98. https://doi.org/10/drxz

van den Berg, A.E., Koole, S.L., van der Wulp, N.Y., 2003. Environmental preference and restoration: (How) are they related? J. Environ. Psychol. 23, 135-146. https://doi.org/10/fb38n3

van Etteger, R., Thompson, I.H., Vicenzotti, V., 2016. Aesthetic creation theory and landscape architecture. J. Landsc. Archit. 11, 80-91. https://doi.org/10/f3vhdf

Vega, S., Rodriguez, E., 2014. Science behind and beyond the Solar Decathlon Europe 2012 competition. Energy Build. 83, 1-2. https://doi.org/10/drwq

Vidal, R., Sánchez-Pantoja, N., Martínez, G., 2019. Life cycle assessment of a residential building with cross-laminated timber structure in Granada-Spain. Inf. la Constr. 71, 37. https://doi.org/10/drx2

Vivar, M., Fuentes, M., Norton, M., Makrides, G., De Bustamante, I., 2014. Estimation of sunshine duration from the global irradiance measured by a photovoltaic silicon solar cell. Renew. Sustain. Energy Rev. 36, 26-33. https://doi.org/10/f593d2

Vlad, A., Singh, N., Galande, C., Ajayan, P.M., 2015. Design considerations for unconventional electrochemical energy storage architectures. Adv. Energy Mater. https://doi.org/10/f3csc6

Wachsmuth, J., 2015. Cross-sectoral integration in regional adaptation to climate change via participatory scenario development. Clim. Change 132, 387-400. https://doi.org/10/f7r6g5

Wachsmuth, J., Blohm, A., Gößling-Reisemann, S., Eickemeier, T., Ruth, M., et al., 2013. How will renewable power generation be affected by climate change? The case of a metropolitan region in Northwest Germany. Energy 58, 192-201. https://doi.org/10/f474rk

Wiser, R., Millstein, D., Mai, T., Macknick, J., Carpenter, A., et al., 2016. The environmental 
and public health benefits of achieving high penetrations of solar energy in the United States. Energy 113, 472-486. https://doi.org/10/f883sh

Wohlwill, J.F., 1976. Environmental aesthetics: the environment as a source of affect, in: Human Behavior and Environment. Springer US, Boston, MA, pp. 37-86. https://doi.org/10/drx4

Yang, R.J., Zou, P.X.W., 2016. Building integrated photovoltaics (BIPV): costs, benefits, risks, barriers and improvement strategy. Int. J. Constr. Manag. 16, 39-53. https://doi.org/10/drx5

Zabalza, I., Scarpellini, S., Aranda, A., Llera, E., Jáñez, A., 2013. Use of LCA as a tool for building ecodesign. A case study of a low energy building in Spain. Energies 6, 3901-3921. https://doi.org/10/f5qhjr

Zangwill, N., 2007. Aesthetic creation. Oxford University Press.

Zhai, P., Williams, E., 2012. Analyzing consumer acceptance of photovoltaics (PV) using fuzzy logic model. Renew. Energy 41, 350-357. https://doi.org/10/djknkv 


\title{
CAPÍtULO 2.
}

\section{AESTHETIC IMPACT OF SOLAR ENERGY SYSTEMS}

\author{
Núria Sánchez-Pantoja ${ }^{\mathrm{a},}{ }^{,}$, Rosario Vidal $^{\mathrm{a}}$, M. Carmen Pastor ${ }^{\mathrm{b}}$ \\ ${ }^{a}$ Department of Mechanical Engineering and Construction, GID, Universitat Jaume I, Av. Sos \\ Baynat s/n, 12071 Castellón, Spain. \\ b Department of Basic and Clinical Psychology, and Psychobiology, Universitat Jaume I, Av. \\ Sos Baynat s/n, 12071 Castellón, Spain. \\ * Corresponding author: nbelengu@uji.es \\ Declarations of interest: none.
}

\section{ABSTRACT}

The presence of solar energy systems has increased significantly in recent years both in rural areas -in the form of solar farms-, and in urban areas as part of building installations. This transformation of the landscape, in spite of the good social acceptance of solar energy, causes an aesthetic impact whose interest has been growing in literature in recent years. This study aimed to review prior literature in order to establish the objective factors, aesthetic perception and methods that are most relevant when assessing the aesthetic impact. As a result of the lack of consensus, a new qualitative methodological framework is proposed that can serve as a basis for future research in the field of the integration of solar energy and its aesthetic impact. The framework comprises three sub-impacts: land use, solar system energy and glare. The results are discussed for future research and innovation in building photovoltaic integration and for SES site location and its environmental impact assessments.

\section{KEYWORDS}

Aesthetic impact, BIPV, Solar Energy Systems, Objective factors, Land use, Glare.

Abbreviations: SES, Solar Energy System; BIPV, Building Integrated Photovoltaics; BAPV, Building Applied Photovoltaics; GIS, Geographical Information System; FD: Fractal Dimension; Cl: Colour; Vi: Visibility; SP: Surface Patterns; F: Frame; Cc: Concurrence; Sh: Shape; PoV: Point of View; ID: Integration Degree; GI: Glare; VS: Visual Saliency; Tr: Transparency Fr: Fragmentation of the installation; TA: Topographic Alterations; Pa: Pattern; CSP: Computer Simulation Pictures; Ph: Photos; KE: Kind of Environment assessed; R: Rural landscapes; U: Urban landscapes; PV, Photovoltaic; OAl $I_{S S P}$ Indicator of Objective Aesthetic Impact developed in (Torres-Sibille et al., 2009); SAM, Self-Assessment Manikin; AHP, Analytical Hierarchy Process; WTA, Willingness to Accept; WTP, Willingness to Pay; CNN, Convolutional neural networks; LSC, luminescent solar concentrators; EIA, Environmental impact assessment. 


\subsection{Introduction}

Solar energy has been promoted in recent decades as an alternative to fight against climate change, and its use has increased significantly. Photovoltaic and solar thermal energy systems (SES) have therefore been in a continuous process of improvement and the energy sector continues to strive to implement them as efficiently as possible. Nowadays, more and more, we find SES in the form of solar farms in rural landscapes, but also SES integrated into the envelope of buildings as part of the urban landscape. The installation of solar thermal systems is more limited in form and design since, for efficiency reasons, they are accompanied by the water facility they serve. However, in the case of photovoltaic systems, the features of their components allow greater freedom in design, being used in the field of architecture where the formal aspect is of great importance. Thus, the photovoltaic installations in buildings are classified in BIPV (building-integrated photovoltaics) when the system is fully integrated into the building envelope as an additional building material, or BAPV (building-applied photovoltaics) when the system is simply located on the roof with a metallic support structure.

Whether in urban or rural environments, several studies support the environmental benefits obtained by using SES (Gunerhan et al., 2008; Turney and Fthenakis, 2011; Wiser et al., 2016). Moreover, there is a general positive perception of SES as a clean and renewable source, although the importance of the user's environmental concern must be taken into account (Gunerhan et al., 2008; Lu et al., 2018; Zhai and Williams, 2012). On the other hand, we also find studies that reveal certain negative aspects to be taken into account (Beylot et al., 2014; Chiabrando et al., 2009; Delfanti et al., 2016; Dubey et al., 2013; Hernandez et al., 2014; Rose and Wollert, 2015; Scognamiglio, 2016). However, even accepting that SES implementation causes environmental impacts such as water usage, wildlife impacts, land use intensity, noise, or hazardous emissions among others, this technology in general is much environment-friendly than traditional energetic sources, even considering wildlife and land use impacts (Turney and Fthenakis, 2011).

The aesthetic perception of the landscape has been the subject of numerous studies for decades (Daniel, 2001; Lothian, 1999; Tveit et al., 2006; Ulrich, 1986), including rural and urban landscape. From an architectural point of view, aesthetic aspects are fundamental, because it is not enough to be functional, as function does not necessarily determine form (Scruton, 2013).

Aesthetic perception of SES implementation has also been considered a relevant question regarding its environmental impacts (Botelho et al., 2017; Chen et al., 2013; Chiabrando et al., 2011; Kapetanakis et al., 2014; Mérida-Rodríguez et al., 2015; Sánchez-Pantoja et al., 2018; Scognamiglio, 2016; Tolli et al., 2016; Torres-Sibille et al., 2009; von Möllendorff and Welsch, 2017). In fact, if we aspire to normalize and promote the exploitation of solar energy, it would be fundamental to increase the 
acceptance of society, transferring indeed this awareness to everyday life (Zoellner et al., 2008). In this sense, we must bear in mind that, in urban environments, the visual appearance of the installation plays a very important role in the end user's preferences (Bao et al., 2017; Lu et al., 2018). Additionally, in rural settings, the perception of the photovoltaic plants has been shown to depend on the visual relationships established by the observers with its environment (Mérida-Rodríguez et al., 2015; Scognamiglio, 2016). Consequently, the requirement to consider visual impacts becomes imperative.

Precisely, the aim of this study was to conduct a review of the literature about aesthetic impact of SES in both rural and urban landscapes. Three relevant features are identified: objective factors, subjective perception and methods. Objective factors refer to those taken into account, or for which its influence on aesthetic perception has been analysed, such as colour, visibility, fractality, etc. Methods include the relationship processes within objective factors and subjective perceptions (such as weighted sum of objective factors).

Based on the literature review, a new qualitative and methodological framework is proposed to serve as a starting point for future research on the aesthetic perception of SES impact. The literature review and the framework proposed here are discussed, considering the limitations of the study, and their application in different areas such as photovoltaic integration assessment or site location.

\subsection{Landscape aesthetics}

According to (Plieninger et al., 2015): "The history of landscape studies can been traced in two broad fields of inquiry: (1) geographical research and (2) art and landscape painting, which make the landscape itself an object worthy of aesthetic admiration. [...] In the twentieth century, new tools and concepts enriched and diverted this approach into a wide array of disciplines. On the one hand, a broader geographical and anthropological branch of landscape studies has considered land and the interactions between human activities and physical geography. On the other hand, cultural geography has incorporated aesthetic and symbolic readings of the landscape with the geographical and art traditions. More recently, social geography has filled the gap between regional studies, i.e., landscape assessment, and cultural geography, i.e. landscape perception, by exploring the question of social and individual well-being. [...] The art tradition was joined with garden architecture and the cultural component of geographical analysis resulting in landscape architecture and landscape planning."

The field of research on society-ecosystem interactions in the context of sustainability is highly complex and a landscape-based approach can be very useful (Bennett et al., 2015). Ecosystem services (Millennium Ecosystem Assessment, 2005) and the related Landscape character (Tudor, 2014) have become general concepts for the expression of values assigned by people to different landscapes. 
Ecosystem services are the benefits that humans obtain from ecosystems, and they are produced by interactions within the ecosystem. Four broad types of service have been recognized: (1) those that cover the material or provisioning services (e.g. food, water, wood, etc.); (2) those that cover the way ecosystems regulate other environmental media or processes (e.g. climate and flood regulation); (3) those related to the cultural or spiritual needs of people (e.g. aesthetic, spiritual, educational, etc.); and finally, (4) the supporting services that underpin these other three categories (e.g. nutrient cycling, soil formation, etc.).

Changes in the landscape affect the human well-being (EU, 2000). Land use intentionally and unintentionally influences the biodiversity as well as the structure and functions of ecosystems. Two types of land use interventions are usually considered in impact assessments: land transformation (or land use change), besides land occupation (Lindeijer, 2000). In accordance with the ecosystem services of the Millennium Ecosystem Assessment (Millennium Ecosystem Assessment, 2005), life cycle assessment covers two main impacts (Koellner et al., 2013): the biodiversity damage potential and the ecosystem services damage potential. The former includes the protection of global species diversity, as well as the functional diversity of species in ecosystems. The latter includes the impact on the production of biomass, the impact on climate by influencing the carbon sequestration in the top soil and land cover, the impacts on water quantity and quality, as well as the impacts on soil quantity and quality. Moreover, landscapes exhibit diversified and interconnected types of values, not all them with objective measures of the impact, such as visualaesthetic, recreational and touristic values.

"Visual impact assessment often uses the term unity as the degree to which all visual elements combine to form a coherent, harmonious pattern" (Bell, 1999), being therefore usually directly related to physical features. From this perspective, aesthetic impact can be related visual disturbance due to perceived landscape interventions as a result of human-made elements that have a disruptive effect because of their size, incongruent style or unintegration with the surroundings and original settings (Pachaki, 2003).

The concept of aesthetic derives from the design theories, linking the descriptors related to landscape with terms developed in other different fields, such as philosophy, psychology and art, posteriorly transferred to landscape contexts (Tveit et al., 2006).

Several theories explain landscape aesthetics in terms of perception and preferences, which are usually "divided into evolutionary theories and cultural preference theories. The evolutionary theories explain landscape perception and preference as [...] a dimension of human fitness and survival, where landscape preferences reflect landscape qualities satisfying human biological needs to survive and thrive as a species" (Tveit et al., 2006). The latter theoretical models argue that perception and experience of landscapes predominantly depend on the cultural 
background and personal attributes of the observer, emphasizing that aesthetic appreciation differs over time and across regions, as well as individuals. These theories usually focus more on affective responses and "personal attributes, such as age, gender, occupation, hobbies, academic background and familiarity" in order to explain the landscape preference (for a review, (Tveit et al., 2006)). In this context, the ecological aesthetic models link preferences for landscape and ethics, suggesting a predisposition for ecologically sound landscapes (Carlson, 2001).

More recently, several approaches to landscape aesthetics have tried to recognize the influence of both cultural (learned) and biological (innate) factors in order to explain landscape preferences (Bell, 1999). According to this new perspective, genetically based preferences are challenged by experience and cultural influences and a synthesis of both points of view is more appropriate for further research concerning the aspects of the visual landscape that most humans respond to. In addition, as the capacity to unfold aesthetic appreciation seems to manifest universally, so this sensitivity should be an intrinsic part of the human biology that has developed throughout the evolution of our species (Berghman and Hekkert, 2017).

One interesting approach that relates landscape architecture with art is the Aesthetic Creation Theory (Zangwill, 2007). This theory states that art function is to have aesthetic properties in virtue of having certain non-aesthetic properties. Thus, aesthetic properties, which must be delineated with reference to beauty and ugliness as the central aesthetic properties, would depend on non-aesthetic ones (van Etteger et al., 2016).

\subsection{Objective factors}

Bishop theory divided the visual impact aspects that we can quantify into three groups: factors related to objects (size, colour), factors related to the environment (visual quality, visual absorption capacity), and factors related to the observer (activity, exposed population). Nevertheless, his research concluded that the greatest interest resides precisely in the relationship between the object and the environment (Bishop et al., 1990; Bishop, 1997). This relationship should be analysed by means of objective factors from the scene itself that can also be easily quantified. However, from a subjective point of view, the influence of the observers themselves should not be underestimated, since several studies have reported a clear influence of the individual's type of professional training on their aesthetic perception (Gifford et al., 2000; Naspetti et al., 2016).

A review of the literature focused on the objective or physical factors influencing on the impact and perception of SES has been carried out, and the most relevant findings are summarized in Table 2. 1. Although research in the area of perception and aesthetic impact is very extensive, the literature is rather scarce and recent 
when we limit the search to the application in the field of SES. Indeed, a total of 24 studies have been analysed, being the oldest published in 2009.

Regarding the means and materials used, most of the studies analysed relied on the use of photographs to carry out the work while a few were based on computersimulated images or other sources such as GIS tools. In fact, numerous studies support the use of pictures to analyse the aesthetic assessment of the landscape or the built environment, both on paper and through online surveys (Bishop, 1997; Naspetti et al., 2016; ShuttleworthS., 1980; Torres-Sibille et al., 2009, 2007).

The aesthetic assessment of products or artworks has been the research focus in numerous studies, as shown by the extensive literature on this subject (e.g. (Braun et al., 2013; Chiabrando et al., 2011; Falomir et al., 2018; Forsythe et al., 2011; Hull and Stewart, 1992; Kapetanakis et al., 2014; Mureika, 2005; Schindler et al., 2017)). However, when this aesthetic assessment refers to SES, we find a greater dispersion or lack of consensus concerning the methodology and the specific relevant factors to be taken into account. Indeed, one thing that should be emphasized is that the approach of the studies summarized in Table 2. 1 is quite broad. In the early years, research mainly focused on the impact of solar energy plants on the ground in rural environments (54.2\% of the reviewed studies). However, this trend has been changing, with urban environments increasingly being considered until becoming the principal focus of research in 2017 (37.5\% of the reviewed studies). Only $8.3 \%$ of the studies include both rural and urban environments in their research. Within studies focusing on the urban environment, $25 \%$ analyse exclusively BIPV systems, $25 \%$ analyse residential solar panels (for BAPV systems) and $50 \%$ analyse PV in urban scenarios in general. Regarding the type of system, although all the papers deal with PV systems, only $8.3 \%$ consider thermal ones.

As shown in Table 2. 1, according to previous literature, a considerable number of objective factors have been somehow addressed by prior studies. However, we must bear in mind that some of these objective factors have little presence in the literature without relevant continuity. To this extent, certain concepts might result a bit confusing, finding also several objective factors that can be grouped together because they are closely related. The analyses performed in this study revealed that the most used objective factors have been visibility (13), colour (9), glare (8), and integration degree (7).

A more detailed analysis of these objective factors certainly helped us to identify the most interesting ones to assess aesthetic impact, as well as to better understand the relationship among them. By its features, we could speak of a first set of factors, independent of others, which refer to simple analytical properties such as colour, shape or transparency; and a second set of factors, more complex and synthetic, which refer to more ambiguous properties such as visibility or the degree of integration and which are inevitably affected by the first set. In the end, we could 


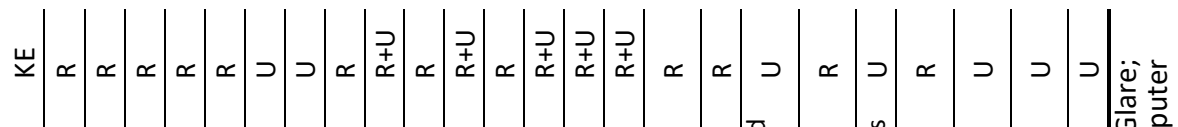

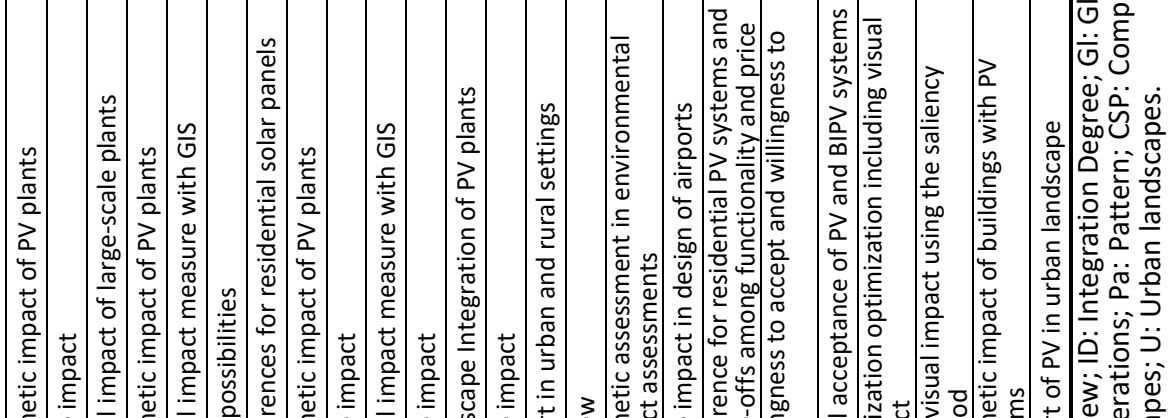

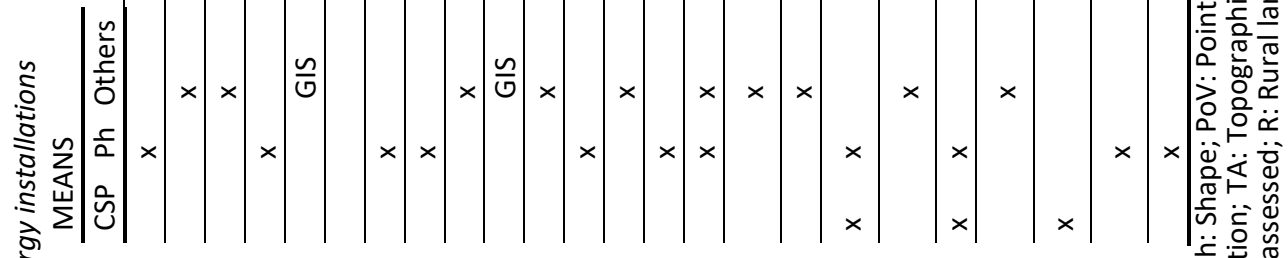

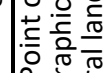

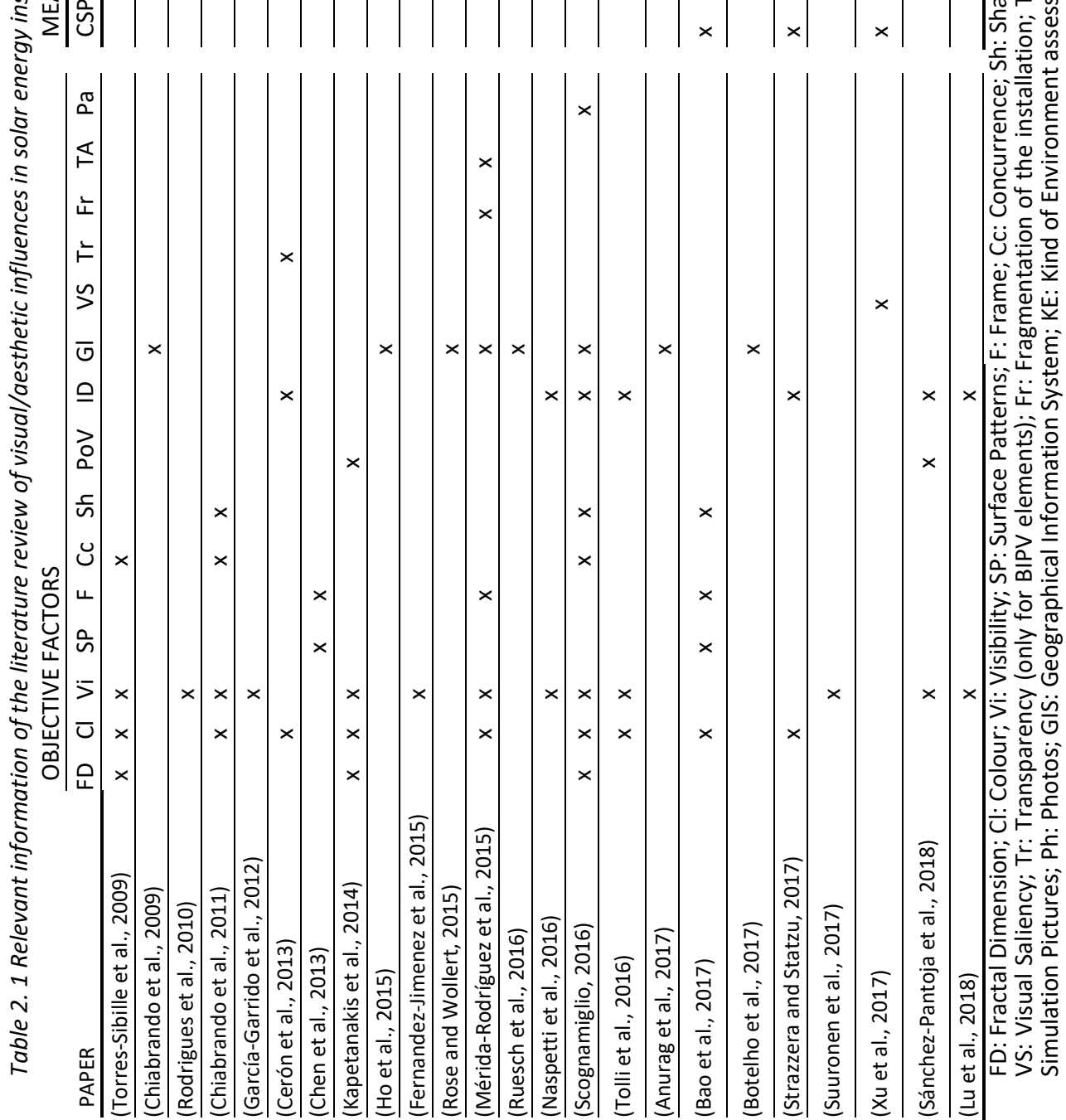


establish a reduced number of objective factors that, according to prior literature and classified in these two groups, should be considered as the most influential features for further research in the field of aesthetic perception.

\subsubsection{First group, simple objective factors}

\subsubsection{COLOUR}

Colour contrast has been considered as a relevant and significant factor for aesthetic perception in numerous studies (Bao et al., 2017; Chiabrando et al., 2011; García et al., 2003; Kapetanakis et al., 2014; Mérida-Rodríguez et al., 2015; Scognamiglio, 2016; Torres-Sibille et al., 2009, 2007). It is also linked to the degree of visibility, understood as perception (Lu et al., 2018). Generally, the colour has been identified based on three parameters (hue, saturation and brightness) by using Photoshop' software. In addition, Lab colour space seems to reflect better the human perception system of the colour response than RGB coordinates (Mureika, 2005).

Neighbouring colours always affect the perception of a specific colour. In this sense, the colour of the walls and the roof are very important for the harmony of the whole (García et al., 2003). Indeed, the impact of the colour has been quantified at $19 \%$ (Torres-Sibille et al., 2009), and this value has been accepted and applied by other authors in their research (Chiabrando et al., 2011; Kapetanakis et al., 2014).

In relation to this factor, we also need to emphasize the "frame", which is evaluated in some studies considering different frame colours or even the absence of it. It is the case of (Chen et al., 2013), who found a certain preference for dark-coloured frames, as well as (Bao et al., 2017), who found that the importance of the frame colour was close to zero.

\subsubsection{GLARE}

Glare is a visual sensation caused by excessive and uncontrolled brightness. It can be disabling or simply uncomfortable. An excessive light produces the disability glare which, as (Carlucci et al., 2015) stated, "consists of immediate reduced visual performance and inability to see given objects and the excessive amount of light causes a photophobic response in an observer who reacts squinting, blinking or looking away". An excessive contrast between illuminated and dark parts of the visual field produces the discomfort glare, which causes in turn "a progressive degradation of the visual performance and leads to premature tiring of the eyes with a subsequent onset of a feeling of discomfort or other symptoms such as headaches". In the literature, various different indices have been proposed to asses or predict glare (for a review, see (Carlucci et al., 2015)).

Glare from SES has been described as a potential risk impact (Botelho et al., 2017; Chiabrando et al., 2009; Rose and Wollert, 2015). However, as the inconvenience is temporary, it has not been included in any impact assessment model along with other objective factors, even though computer software tools are currently able to 
quantify and visualize glare situations for a specific situation (Ho et al., 2015; Rose and Wollert, 2015).

Several comprehensive reviews on anti-reflective coatings (ARC) have been published in the literature (Cai and Qi, 2015; Hanaei et al., 2016; Hedayati and Elbahri, 2016; Kumar et al., 2011; Yao and He, 2014). Many materials with micro or nano structure are reported as ARC, including silicon, silica, titanium oxide, zirconia, zinc oxide, cobalt oxide, tin oxide, carbon, polymer based (PET, PS, PMMA) and gallium nitride. Absorbing layers have also been used for reduction of reflections (Atkinson et al., 2015; Cai and Qi, 2015; Hedayati and Elbahri, 2016) and recently plasmonic metal based has emerged as ARC (Cai and Qi, 2015; Hedayati and Elbahri, 2016). Silicon nitride films deposited by plasma-enhanced chemical vapor deposition and silicon dioxide are the industrial standards for ARCs on crystalline silicon substrates and glass respectively (Cai and Qi, 2015; Yao and He, 2014). The ARCs are often endowed with superhydrophilic or superhydrophobic properties to prevent the accumulation of dust on modules which can reduce significantly net efficiency, i.e. carbon nanotubes (Hanaei et al., 2016).

\subsubsection{PATTERN - TEXTURE}

Texture/Pattern has been explored in several studies by using different terms, but all of them considered the surface appearance as an influential factor in the aesthetic evaluation. For instance, the term "surface complexity" has been used, defining different levels of texture and ornamentation on the façade in order to assess their influence to subjective impressions for choice. The conclusion was that there is a high correlation between texture and preference (Stamps, 1999).

The influence of the texture of agro-industrial buildings on the preference for integration has also been analysed (García et al., 2006). In this case, texture was evaluated based on four parameters: grain size (relative to the total size of the picture), density (elements per unit area), internal contrast (diversity of colours and surface luminosity), and regularity (homogeneity level of the spatial distribution). According with that research, these parameters influence the visual continuity, which is considered to be the most important in order to achieve a good integration. In general terms, texture does not seem to be a determining factor in prior research, but the conclusions of that research highlighted the important role that "distance" plays in relation to texture, which is a factor that has a great influence on the urban environment.

If we focus on the factors that can influence solar energy installations, the term "pattern" has been used more often to define the physical characteristics of the panels (Bao et al., 2017; Scognamiglio, 2016). However, the term "surface appearance" has been similarly used (Chen et al., 2013). In all of these investigations, the factor being measured is actually the texture of the panel surface, which was found to be valuable in relation to the visual appeal of PV panels. To this extent, the 
less evident these patterns were, the more appealing the panels became. Within the term pattern, we can include concepts such as the "density/porosity" (Scognamiglio, 2016), as well as the "transparency possibilities" in the case of BIPV installations (Cerón et al., 2013).

\subsubsection{FRACTALITY}

Fractality - normally applied through the unit of measurement of the Fractal Dimension (FD) - is a geometric feature incorporated in aesthetic landscape studies since Mandelbrot began to perform mathematical analyses of fractal geometry on the nature (Mandelbrot, 1982). The term fractal has been explained in several studies, but a simple and clear definition could be that "a fractal is a visual image some features of which repeat at many different scales" (Stamps, 2002).

The use of FD in research has been strongly related to the mathematical description of geometry and especially applied to nature. We find several studies where fractality was used to analyse perception and preference of artworks (Braun et al., 2013; Forsythe et al., 2011; Mureika, 2005). Similarly, we also find another group of studies where this parameter is calculated for skylines and silhouettes in order to analyse its influence on landscape perception and preference (Bovill, 1996; Hagerhall et al., 2004; Kapetanakis et al., 2014; Stamps, 2002; Torres-Sibille et al., 2009, 2007). Some of these authors have used the expression "silhouette complexity" in a similar way to the FD of the skyline or the silhouette (Hagerhall et al., 2004; Kapetanakis et al., 2014; Stamps, 1999; Torres-Sibille et al., 2009, 2007).

Another term related to fractality is "shape" (Chiabrando et al., 2011), used instead of fractality with the aim to apply the indicator OAlssp to some case studies. This indicator is proposed by (Torres-Sibille et al., 2009) "for the quantification of the objective aesthetic impact, based on four criteria: visibility, colour, fractality and concurrence between fixed and mobile panels", and consequently applied by other authors (Chiabrando et al., 2011; Kapetanakis et al., 2014). The term "shape" has been similarly used, but on another scale, by other authors (Bao et al., 2017), although it was not related to fractality but rather to additional parameters such as pattern or texture, since these researchers considered the shape of the photovoltaic cells that make up the panel.

Without any doubt, the fractal dimension has been repeatedly used for judging aesthetics of landscape and impacts; however, we cannot affirm that its relevance to aesthetic preference has been proved. "Urban design decisions regarding skylines should not assume that matching fractal dimension of skylines and landscapes is a good idea" (Stamps, 2002) but "the significant relationship between preference and the fractal dimension", highlighting the limitations of working with contours (Hagerhall et al., 2004). On the other side, the influence of fractality on aesthetic impact was quantified as $9 \%$, behind other factors such as visibility or colour (TorresSibille et al., 2009, 2007). However, even though fractal describes fractured shapes which repeat patterns and fractal dimension seems to be an ideal factor for judging 
the aesthetics of a pattern (Hagerhall et al., 2004), it is striking that this factor related to the analysis of texture or pattern has not been used in closer environments such as the urban landscape.

This lack of coherence in the results is justified by the disparity in the methodology used for measuring fractal data (Vaughan and Ostwald, 2017). For this reason, their work is focused on establishing a new framework to compare the built and natural environment, using the box-counting method of fractal analysis and performing a previous categorisation of graphical data into similar types (line drawings, perspectives, 2D photograph, etc).

\subsubsection{Second group, complex and objective factors}

\subsubsection{VISIBILITY}

In accordance with literature, visibility appears to be a very relevant, primary factor both for measuring the aesthetic impact and for assessing pleasure of SES implantation. Indeed, the current revision suggests that visibility is the most used and clear influence factor, as it seems quite logical that there is no aesthetic impact when it is not visible, with the exception of the land use alteration.

There are several indexes to measure visibility (Rodrigues et al., 2010) and the application of this factor vary depending on the purpose for which it is intended. In the studies where the objective was to measure the quantity of aesthetic impact that the PV plant caused on the rural landscape, visibility was considered by the percentage of area that the PV installation took up with respect to the total landscape area (Chiabrando et al., 2011; Kapetanakis et al., 2014; Torres-Sibille et al., 2009). For site selection on new SES, literature provides geographic information systems methods (GIS) (Fernandez-Jimenez et al., 2015; García-Garrido et al., 2012; Rodrigues et al., 2010; Suuronen et al., 2017) and two approaches can be distinguished: one option consists in considering as potentially visible any installation included in a certain radius $(5-10 \mathrm{~km})$ around cities, roads, natural and historical monuments, and landscape with scenic value (Suuronen et al., 2017); and the other approach is directly related to its observability (Fernandez-Jimenez et al., 2015; García-Garrido et al., 2012; Scognamiglio, 2016). When the SES “is not visible from the places frequented by people, its visual impact will be negligible. The visual impact of the plant increases when it is visible from more places and for more people. Even with a fixed number of people for whom the plant is visible, its visual impact is raised with an increase in the possible hours of observation" (Fernandez-Jimenez et al., 2015; García-Garrido et al., 2012). In this sense, it is very important to take into account the "point of view" from which the images to be evaluated are taken, since the visibility of the installation depends largely on it.

All authors who have assessed visibility and integration level of PV systems have confirmed its influence in aesthetic perception. The impact of the visibility has even 
been quantified at $64 \%$ (Torres-Sibille et al., 2009), and this value has been accepted and posteriorly applied in further investigations (Chiabrando et al., 2011; Kapetanakis et al., 2014).

\subsubsection{INTEGRATION DEGREE}

Integration degree is a demonstrated influencing factor whose complexity lies in the way it is measured and applied. Indeed, it has been considered as one of the two objective factors that most influence visual impact (Scognamiglio, 2016).

There is no consensus or rigour in applying this factor and none of the studies consulted defines a clear, comparable and unambiguous way of measuring the degree of integration. For example, SES were classified in three categories "nonintegrated", "partially or semi- integrated" and "integrated" by (Lu et al., 2018; Naspetti et al., 2016), although no explanation of the criteria used for this classification has been provided. Other researchers simply use the BIPV concept to refer to cases where the system is considered integrated (Strazzera and Statzu, 2017). Finally, other research established a categorization according the following criteria "the PV installation is seen, perceived and understood", "part of the PV installation is seen and perceived" and "the PV installation is not seen" to refer to the integration level (Sánchez-Pantoja et al., 2018).

In general, a good level of integration of photovoltaic systems is highly recommended, but it has been shown that, while less experienced people tend to prefer more hidden solutions, experts tend to prefer well integrated designs even if they are visible (Naspetti et al., 2016). In addition, there is a clear trend showing that the more people see and perceive the photovoltaic installation the less they score the liking (Sánchez-Pantoja et al., 2018).

\subsubsection{Other factors}

The "visual saliency" is a concept borrowed from the computer vision domain, which means the probability of a particular image region attracting human visual attention in comparison to its surrounding. The saliency models extract information from colour contrast, light contrast and orientation of the image. Additionally, render images are generated with a software that is capable of following the physical behaviour of the light (Xu et al., 2017). Note how this objective factor includes, at least partially, other significant objective factors mentioned above, such as colour and glare.

"Fragmentation" of the installation has also been considered in rural landscapes as "the way the components of the PV installation are grouped together" (MéridaRodríguez et al., 2015). In this case, plausible impact would come from unoccupied spaces where land is visible (creating colour contrast), being greater when the distribution of the rows breaks the natural contour lines, then causing the observer to lose visual references to the natural environment. The same authors have 
additionally considered the "topographic alterations" as an interesting visual factor referring to the introduction of geometrical shapes and lines, non-traditional materials, and with high reflectivity. In other words, the fact of causing important alterations of the relief and, as a result, the lack of coherence and legibility of the landscape (Kaplan and Kaplan, 1989).

Without belonging properly to the installation or being able to be considered as objective factor of the SES, the "climatic conditions" are a parameter that affects the aesthetic of the picture, and may vary factors such as visibility or colour (Chiabrando et al., 2011; Kapetanakis et al., 2014; Torres-Sibille et al., 2009). Thus, when comparing installations, it would be advisable to take photographs on similar days and under optimal atmospheric conditions in order not to interfere with perception.

\subsection{Emotions and aesthetic perception}

\subsubsection{Emotion conceptualization and structure}

For many authors, an emotional response begins with appraisal of the personal significance of an event (Lazarus, 1991; Scherer, 1984), which in turn gives rise to an emotional response involving subjective experience, physiology, and behaviour (Frijda, 1988; Gross, 2007; Lang, 1988; Larsen and Prizmic-Larsen, 2006). The review of literature regarding aesthetic perception shows that is not merely a cognitive process but also involves feelings within diverse "domains such as music, literature, film, painting, advertisements, design, and architecture" (Schindler et al., 2017). Aesthetic pleasure or displeasure sensations thus conceived correspond somehow to affective responses that might guide our adaptive behaviour (Damasio and Carvalho, 2013), and support perception in many different contexts (Barrett and Bar, 2009).

A considerable amount of researchers have been interested in this topic over the last three decades. However, psychologists and affective neuroscientists have not reached consensus, neither in the definition of what is an emotion, nor in the elements that should be taken into account to accurately measure human emotions. This lack of agreement reflects the open debate regarding the structure of the emotional world, which some authors prefer to explain in terms of a number of discrete, basic emotions, while another scientists propose that is better described considering a few fundamental dimensions that organize emotional responses.

Most researchers focused on human emotions commonly adopt a multi-level framework that involve three distinct components: (1) a subjective experience (i.e., labelling, rating feelings); (2) physiological changes in brain and body (i.e., sweating palms, racing heartbeat, rapid breathing); and (3) a behavioural or expressive response (Bradley and Lang, 2000). The convergence across measures of emotion of each component has been scarce, reflecting the level of complexity underlying the 
emotion world (Cacioppo et al., 2000). Emotions, therefore, are multiply determined rather than characterized by a one process, and cannot be captured with any single measure alone (Mauss and Robinson, 2009). Due to the complexity nature of emotions, at the moment there is no "gold standard" measure of emotional responding. More exactly, experiential, physiological, and behavioural correlates are all similarly relevant to understanding emotional perception and emotional reactions, and cannot be assumed to be interchangeable or excluding measures of emotion (Mauss and Robinson, 2009).

According to the dimensional perspective, numerous researchers currently adopted a framework where emotions can be considered as basically "organized around two motivational systems, one appetitive and one defensive, which have developed to mediate transactions in the environment that either promote or threaten physical survival (Lang et al., 1997)" (Bradley et al., 2001). In addition, "the motivational model accounts for emotion's basic parameters of hedonic valence and arousal, as defined by research on affective language and feeling". Thus, judgements of pleasure or displeasure would indicate which motivational system is active (i.e., pleasantappetitive vs. unpleasant-defensive), whereas judgements of emotional arousal would reflect the intensity of motivational activation. Even though these reports might be influenced by personal, situational or cultural factors, the underlying biological determination has been supported by many different experimental studies along the past three decades. In fact, when people are asked to rate or judge the hedonic valence and arousal of a wide range of emotional stimuli such as pictures, sounds, words, movies, and music, the resulting bi-dimensional affective space has been clearly replicated, consistently furthermore with the above motivational model (Bradley et al., 2001).

\subsubsection{Assessment of aesthetic emotions of landscape}

Interestingly for our revision concerning the impact of SES, elicitors of aesthetic emotions are not limited to the arts in the precise sense, but extend to design, built environments, constructions, nature and landscape (e.g. (Nasar, 1992; Ulrich, 1986; Wohlwill, 1976)). For instance, exposure to nature has been linked to reduced fear and physiological activation, besides more awake relaxation (Ulrich, 1986; Ulrich et al., 1991). In addition, (van den Berg et al., 2003) showed "that a greater aesthetic preference for natural environments as compared with built cultural habitats is partially explained by the greater affective restoration offered by natural environments" (Schindler et al., 2017).

Measuring the emotions that occur in response to the perceived aesthetic appeal of such a broad range of stimuli (i.e., music, literature, film, painting, advertisements, design, architecture, nature and landscape) has been a challenge for many decades for researchers interested in aesthetic perception. Indeed, many different 
instruments with a variety of scales and measured constructs have been used across the variety of specific domains, adding difficulties when comparing emotion profiles across domains or replicating prior results (for a review, see (Schindler et al., 2017)).

In relation to aesthetic perception, there has also been a lack of agreement in terms of which specific particular emotions are relevant in particular domains. In general, empirical studies throughout numerous art domains have mainly focused on three different categories of emotion: "prototypical aesthetic emotions (e.g., the feeling of beauty, being moved, fascination, and awe); epistemic emotions (e.g., interest and insight); and emotions indicative of amusement (e.g., humor and joy)". Additionally, some instruments in this field have also tried to capture "the activating (energy and vitality) and the calming (relaxation) effects of aesthetic experiences, as well as negative emotions that may contribute to aesthetic displeasure (e.g., the feeling of ugliness, boredom, and confusion" (for a review, (Schindler et al., 2017)).

In the field of aesthetic perception, current research points out that affective responses should necessarily be taken into account as they play a central role in accounting how stimuli are processed and impact in the observer (Schindler et al., 2017). Additionally, in the specific case of the SES, the new use of land causes strong landscape contrasts that result in a clear visual impact that might certainly be perceived as negative by the citizens. To this extent, researchers have mainly employed general measures of emotion developed to assess basic emotion dimensions rather than specific emotions related to experiences of the aesthetic appeal of stimuli. For example, "Scales of Affective Quality Attributed to Places" a self-report questionnaire was used for assessing aesthetic perception in built and natural environments (Galindo and Rodríguez, 2000; Russell and Pratt, 1980).

\subsubsection{Assessment of aesthetic emotions of Solar Energy Systems (SES)}

In line with the dimensional perspective, we find several studies based on the semantic differential technique, in which the basic parameters to assess emotions were hedonic valence and arousal (Mehrabian and Russell, 1974; Osgood, 1962). Accordingly, (Bradley and Lang, 1994) developed the Self-Assessment Manikin (SAM), based on these basic dimensions, proposing this non-verbal instrument that includes a pictorial scale for assessing emotional reactions free of language interferences. The use of this instrument for the evaluation of the aesthetic perception of photovoltaic installations in prototype solar dwellings (in terms of hedonic valence and emotional arousal) was satisfactorily used (Sánchez-Pantoja et al., 2018). In this study, participants were presented with pictures of different BIPV and BAPV prototypes and they had to rate how pleasant-unpleasant and arousing felt when seeing these stimuli.

Semantic differential method was also applied by (Torres-Sibille et al., 2009) in order to analyse the aesthetic impact of different solar power plants on humans. Based on 
the studies of (Küller, 1979), the concepts used in this study were "Pleasantness", "Complexity", "Coherence", "Openness", "Affection" and "Originality". This research concluded that a combination of objective and subjective aspects would help to control their aesthetic impact. Subsequently, another study adds 4 more concepts to this list: "Naturalness", "Liveliness", "Stimulation", "Degree of protection" (Scognamiglio, 2016).

On the other hand, (Bao et al., 2017) evaluated the preference for photovoltaic systems integration through 1-7 Likert scales. And also, investigations such as those of (Lu et al., 2018) and (Naspetti et al., 2016) collected subjective perceptions and preferences of the individuals about PV systems, by asking to sort pictures according to the level of their subjective aesthetic liking. Awarding points to this ranking allows them to measure the preference.

\subsection{Aesthetic impact methods}

In this section, we present a review of the literature on methods that link objective factors and subjective perception of the aesthetic impact of SES, beyond the use of statistical validation techniques. Some of these methods can be used to valuate aesthetical impacts, although initially they were used to determine the most influential objective factors from subjective perception.

\subsubsection{Weighted sum}

During several years, the weighted sum method was the only one published to measure the aesthetic impact of solar systems. The method initially created for wind farms (Torres-Sibille et al., 2007) was posteriorly applied by the same authors to SES (Torres-Sibille et al., 2009), being thereafter replicated in subsequent investigations (Chiabrando et al., 2011; Kapetanakis et al., 2014).

The aesthetic impact indicator can be defined as a weighted average of individual impacts obtained from objective factors, such as the visibility of the plant, the colour compared to the colour of the immediate surrounding, the fractality of the panels, as well as the concurrence of various forms and types of panels in the same plant. Each individual impact is calculated through a curve determined through a survey of ten experts and evaluators (Torres-Sibille et al., 2009).

The weights have been given by expert judgement in a Delphi procedure, and analysed by means of the analytical hierarchy process (AHP) in a multicriteria approach. This method has been tested with a population survey, in which over $80 \%$ of the overall aesthetic impact measured with this method was attributed to the visibility and colour of the plant (Chiabrando et al., 2011). 


\subsubsection{Mixed logit}

The user preference for different attributes of a solar panel was modelled using the mixed logit model (Bao et al., 2017). Here, the utility is a measure of preferences over different alternatives. The inputs of the model are discrete values of the objective factors: colour, shape, pattern and frame. The weighted coefficients are not fixed. They can be estimated by maximizing the log-likelihood of the probability of observed choices. However, the coefficients of the mixed logit models are not estimated on an absolute scale; conversely, the attribute importance is generally estimated, which is a standardized measure of the weight of each objective factor (MacDonald et al., 2009). As a result, the importance of colour is the most critical factor of visual appearance. However, the contribution of shape and pattern has similar values, whereas the significance of the frame seems to be close to zero. An additional set of images has been constructed with solar panels installed on the roofs of houses, suggesting that colour might be a major factor in visual preference. Indeed, all solar panels were rated higher when observed on a roof with the same colour (Bao et al., 2017).

\subsubsection{Visual Q}

Visual Q methodology has been used to assess the impact of photovoltaic applications on the landscape in urban and rural areas of Italy (Naspetti et al., 2016), as well as in urban areas of China (Lu et al., 2018).

As defined by (Naspetti et al., 2016), Q methodology "combines quantitative statistical methods with the qualitative evaluation of individual preferences. [...] Using a visual Q-methodological approach, the landscape and land use may be measured through the qualitative ranking of items in a forced distribution by different individuals. During $Q$ sorting, each participant expresses his/her personal viewpoint by ranking the visual items. The resulting $Q$ sorts are then factor analyzed in order to recognize common patterns and to identify specific points of view surrounding the topic under investigation." $Q$ methodology follows the customary five steps (McKeown and Thomas, 2013): definition of a "concourse" of images, selection of a $Q$ sample, selection of the $P$ set, collection of $Q$ sorts, and factor analysis.

Different photographs have been selected in order to investigate the perspectives of experts and non-experts towards the impact of photovoltaic systems on the landscapes. In the two studies analyzed here (i.e. (Lu et al., 2018; Naspetti et al., 2016)), the landscape had three levels as photovoltaic plants that were 'nonintegrated', 'partially integrated', and 'integrated'. In addition, the first factor was photovoltaic systems integrated with landscape structures (with more of $25 \%$ of the explained total variance). Both studies also matched in a factor that emphasized photovoltaic applications on roofs that were out of the public eye. Other factors focused on offering economic or social benefit together environmental benefits. 
Additionally, all participants showed a preference for integrated photovoltaic applications rather than semi-integrated or non-integrated photovoltaic applications.

\subsubsection{Economical valuation}

Nonmarket valuation techniques are used when the market cannot provide decisionmakers with price information about goods or services. This is the case of eliciting welfare changes caused by the operation of SES, since these impacts are not "traded" in markets. The environmental impacts are mostly experienced locally, while the benefits from cleaner energy seem to be shared by all. For this reason, two economic nonmarket valuation techniques could complementary be used (Botelho et al., 2017): eliciting the willingness of local respondents to accept for local impacts (i.e., willingness to accept or WTA), or eliciting the willingness of national respondents to compensate local residents for local impacts (i.e., willingness to pay or WTP).

Glare is the only objective factor considered in the two models (Botelho et al., 2017) for large grounded SES, although a generic landscape factor is also included in the WTP model. Nuisance from the glare effect has a significant level in the two models. WTP has also been used to estimate the land use impacts due to the loss of naturalness as consequence of the installation of SES (Lakhani et al., 2014).

\subsection{Methodological framework proposal}

The wide range of factors found in the literature and the lack of consensus regarding how to apply them in order to assess the impact of SES implementation, make it very difficult to compare them. It was therefore imperative to carry out a detailed review of the factors and methods used in the literature and an in-depth synthesis exercise to define a framework to serve as a starting point for future research on the aesthetic impact of SES.

In order to be able to relate objective factors with perception, in the methodological framework proposed here the aesthetic impact is broken down into three levels or sub-impacts. The first level, called Land use, considers the alteration in the quality of the landscape because of the SES installation. This sub-impact depends on the size. Note that in life cycle impact assessment, land use inventory flow for land occupation and land transformation are relative to the size of the disturbance, being measured in $\mathrm{m}^{2}$.years and in $\mathrm{m}^{2}$ (Koellner et al., 2013). The level Land use explains the different aesthetic perception of the same installation in different locations (Lakhani et al., 2014; Naspetti et al., 2016): nil (or near nil) in urban landscape and negative in landscapes of high quality not transformed by man. This means the type and environmental value of landscape influence the aesthetic perception. There are no Land use impacts from residential and commercial rooftop systems as they utilize rooftops of existing buildings (Lakhani et al., 2014). 
The second level, called SES, considers the aesthetic perception of the own SES, regardless of location. This sub-impact depends on the more complex factors: visibility and the degree of integration. Visibility is mainly related to the size of the facility in rural settings but also to the human factor (see section 2.2). However, in urban environments, visibility could be also related to the location of the system (roof, façade). On the other hand, perception for SES improves with higher degrees of integration (Lu et al., 2018; Naspetti et al., 2016; Sánchez-Pantoja et al., 2018; Scognamiglio, 2016). The degree of integration is not unique to the building envelope (BIPV) but should also consider the overall integration with the landscape (Scognamiglio, 2016), including rural environments. The value of this sub-impact is influenced in turn by the first set of factors such as colour, texture, fractality, that nuance the visibility or degree of integration of the SES (Bao et al., 2017; Chiabrando et al., 2011; Kapetanakis et al., 2014; Mérida-Rodríguez et al., 2015; Scognamiglio, 2016; Tolli et al., 2016; Torres-Sibille et al., 2009). The aesthetic perception for this level is expected to be almost zero or negative when the degree of integration is zero. On the contrary, the aesthetic perception is expected to be between zero and positive when the level of integration is at its maximum, since then the positive perception of solar energy as a clean, renewable and environmentally beneficial prevails (Lu et al., 2018; Naspetti et al., 2016; Sánchez-Pantoja et al., 2018).

The third level, called Glare, includes the negative perception produced by glare (Botelho et al., 2017; Chiabrando et al., 2009; Ho et al., 2015; Rose and Wollert, 2015). This sub-impact depends on visibility (Lu et al., 2018), referring to the visibility of the glaring beam. In addition, note that the time scale for the human factor here is different from the second level. The value of this sub-impact is influenced by the reflection properties of the materials (Ruesch et al., 2016).

Fig. 2. 1 shows graphically the framework proposed. The sub-impacts Land use, SES and Glare are represented on 3D in 1a, $1 \mathrm{~b}$ and 1c, respectively. The overall aesthetic impact is represented on $2 \mathrm{D}$ in $1 \mathrm{~d}$, without considering the size-visibility axis. Aesthetic impact is always referred to visual perception and represented on the Zaxis. This impact increases as the perception decreases. A positive perception corresponds to a negative aesthetic impact and the other way around. Aesthetic impacts are expressed in ranges because perception varies from person to person, from landscape to landscape (Plieninger et al., 2015) and among different kind of systems.

The degree of integration is represented on the $X$-axis. A minimum value of zero has been set when no effort was made to integrate the installation (e.g. solar panels placed on the roof and oriented to receive the highest amount of radiation). The maximum value would be one when there is a perfect integration of the installation in the landscape or in the building. 
1a) Land use

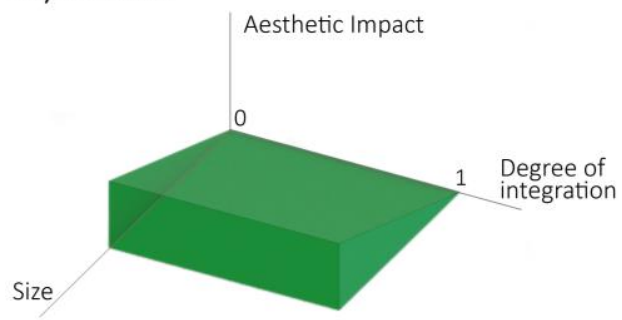

1c) Glare

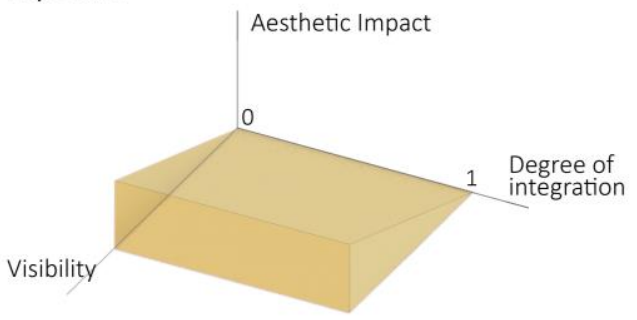

1b) SES

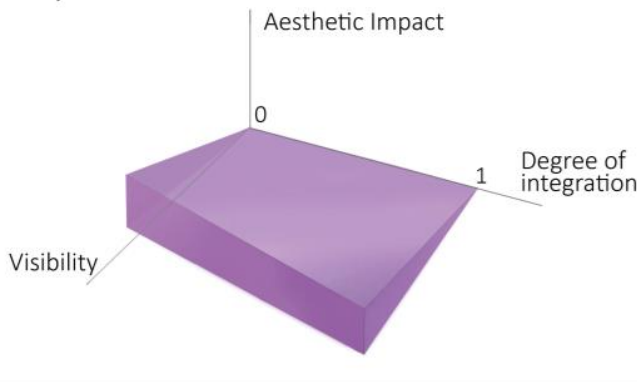

1d) Overall aesthetic impact

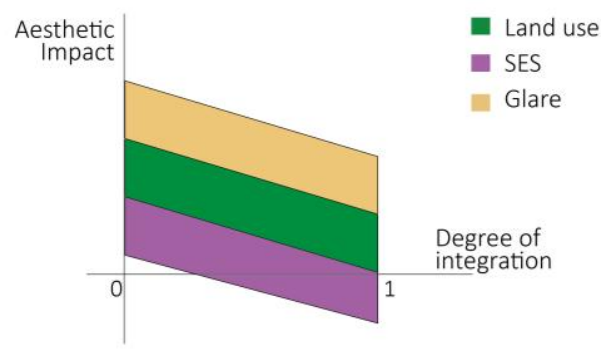

Fig. 2. 1 Graphic representation of the qualitative methodological framework. 1a) Land use sub-impact; 1b) SES sub-impact; 1c) Glare sub-impact; and 1d) Overall aesthetic impact.

The $\mathrm{Y}$-axis represents the size of the facility when assessing the impact of the subimpact Land use and the visibility when assessing the sub-impacts SES and Glare. For the three levels, the aesthetic impact would be zero for the $y$-axis equal zero.

\subsection{Discussion}

The analysis of the objective factors found in the literature revealed the lack of unanimity in applying them to assess the different levels of impact. The most important factor that should always be taken into account when assessing aesthetic impact of a SES implementation is visibility. Nevertheless, the importance of a nuanced concept of visibility has been demonstrated, which would refer to the size when evaluating the aesthetic impact of Land use (Koellner et al., 2013; Suuronen et al., 2017); the visible percentage of the installation to assess the aesthetic impact of a SES (Chiabrando et al., 2011; Kapetanakis et al., 2014; Torres-Sibille et al., 2009); and the observability of the glaring beam to evaluate the aesthetic impact of Glare (Ho et al., 2015; Rose and Wollert, 2015). Additionally, although the set of simple and independent objective factors do not change the amount of visible area of the facility, they can influence the impact of the installation to be greater or lesser depending on the visual continuity and the contrast (García et al., 2006).

Integration degree has turn out to be the second most relevant objective factor. This integration will be more related to the natural environment in the case of solar farms 
and to architectural construction elements in urban environments. However, it should be borne in mind that this factor could also be influenced in turn by numerous simple factors such as colour contrast, pattern-texture or fractality. For instance, harmonious colour contrast and less evident patterns enhances integration (Bao et al., 2017; Chen et al., 2013; García et al., 2003; Scognamiglio, 2016). Additionally, fractality should be considered when analysing perception in a natural environment (Chiabrando et al., 2011; Hagerhall et al., 2004; Kapetanakis et al., 2014; Stamps, 2002; Torres-Sibille et al., 2009). Recently, the adoption of the saliency from the computer vision to the aesthetic impact of SES has opened the door to new and interesting measures (Xu et al., 2017). The most important problem in analysing the integration degree is the lack of a clear and unambiguous method to measure this factor. For example, photovoltaic integration in a natural environment is very different from those that can take place in a building envelope. Not only simple objective factors are involved, but other particularities such as the ability to assume other functions or subjective perception of the observer should also be considered. This brings some uncertainty to the results where this factor is taken into account. Consequently, integration degree should be the subject of an in-depth analysis in order to establish clear criteria for measuring integration, considering the wide variety of existing photovoltaic systems and locations.

Future research should combine other measures indicative of aesthetic perception beyond self-report questionnaires, in order to evaluate more accurately the affective reactions linked to this appreciation, independently of which specific emotions or broad dimensions are emphasized (Schindler et al., 2017). "These should include behavioural observations in field studies or in the lab (e.g., eye movements, time spent in a specific location, viewing or reading time, preferences for specific environments, movement speed and pattern), and physiological measures (e.g., facial muscle activity, pupillary dilation, patterns of brain activation, among other measures)".

In addition, further studies should explore relevant differences between the aesthetic responses of experts and laypersons in the assessment of perceived aesthetic virtues of landscape and SES impact (Schindler et al., 2017). "While attenuated emotional responses to positive and negative artworks have been found in experts (Gerger et al., 2014), this finding may hold true only for the negative and pleasing emotions studied" (Schindler et al., 2017). In this line, "it is possible that experts show more intense prototypical aesthetic emotions and epistemic emotions" such as greater interest, compared to novices (Silvia, 2005).

Another approach for further research would be to explore what personal features might be helpful to the experience and perception of aesthetic emotions. For instance, empathy (Eerola et al., 2016) and openness to experience (Silvia et al., 2015) seems to facilitate the experience of prototypical aesthetic emotions. Further studies could therefore help determine whether some relevant personality traits are 
strongly related to specific aesthetic emotions, and whether these associations between personality and emotional perception account for individual differences in aesthetic preferences in a broad range of domains, including negative or disruptive impact in landscape derived of SES implantation.

Similarly, further research exploring the dynamics in the aesthetic perception is needed. On the particular domain of SES, possible variations in aesthetic understanding and appreciation in tomorrow's landscapes might occur, even within the same locations and populations. It means that negative aesthetic perceptions could be overcome and new preferences might develop over time (Nohl, 2001), or even that SES interventions could become part of the everyday landscape and most people get accustomed, likewise happened with wind energy. Consequently, even when it might be extremely premature to reach conclusive inferences on this matter due to the shorter development time of SES, the assessment of its aesthetic impact constitutes a relevant factor to be considered for technical progress and future planning policies.

The literature review for SES shows very few studies in which aesthetic perception has been valued besides very little variety of methods. Literature about perception and emotions in other fields presents interesting alternatives based on fuzzy, cognitive maps, intelligent agents, etc. (Kowalczuk and Czubenko, 2016). Obviously, these models alike the emergent results from computational aesthetics offer new research possibilities for the aesthetic assessment of SES.

Recently, researchers in computer vision have also gained interest for the aesthetic topic, giving rise to the field of computational aesthetics, for a review (Brachmann and Redies, 2017). For aesthetic perception of SES is especially significant the research in prediction of ratings. Initially in this field, objective factors (or features) were used to train a classifier on a dataset of images so that it can learn to predict aesthetic ratings given by humans. In recent years, computational aesthetics has progressed thanks to the use of generic features developed for other purposes in computer vision like object detection and classification or image retrieval. This development has reached a zenith with the development and widespread use of deep neural networks, in particular convolutional neural networks (CNN) (Denzler et al., 2016; Kao et al., 2017; Lu et al., 2015). Nevertheless, little attempts have been made to apply CNNs as the underlying model for aesthetic perception (Denzler et al., 2016). Here, "the goal is to find out on what grounds aesthetic judgement are made by human observers and what their biological basis and evolutionary purpose might be" (Brachmann and Redies, 2017). CNN and "generic features basically represent a black-box approach that lacks of interpretability. [...] Understanding deep representations in the future, the drawback of deep learning approaches may eventually turn out into an asset for understanding aesthetics" (Brachmann and Redies, 2017). 
The proposed framework presents a significant limitation due to the fact that it is absolutely based on the literature reviewed and there is no data to prove its validity. However, given the lack of consistency in the papers revised, the authors have tried to synthesize the results found in prior investigations in order to establish a common meeting point on which to base future research in the field of SES aesthetic perception.

An interesting line of future research would be the verification of the framework proposed in this article or the provision of data to improve its approach. The final objective would be to be able to foresee the social aesthetic acceptance of the new technologies of photovoltaic integration in design phases. Although landscape values are closely connected to landscape patterns, intensity of use and structure, they cannot be assessed in terms of purely material site attributes. Moreover, people needs experience landscapes and engage with them in the course of landscaperelated practices (Plieninger et al., 2015). Findings of the review and the methodological framework proposed are discussed below applied for future research and innovation in building photovoltaic integration and for SES site location and its environmental impact assessments.

\subsubsection{Application to building photovoltaic integration assessment}

In European countries, public opinion about energy developments is generally positive for renewable energy systems (RES), even though the acceptance of many projects of on-ground large PV plants might cause local resistance or discontent (Scognamiglio, 2016). However, studies assessing the aesthetic perception concerning photovoltaic integration have generally shown very favourable results (Lu et al., 2018; Naspetti et al., 2016; Sánchez-Pantoja et al., 2018; Strazzera and Statzu, 2017).

Differences between the integration of SES in buildings and rural landscapes are evident. This change of scale provide a different level of complexity and other design parameters should be considered (Scognamiglio, 2016). Moreover, architectural design objectives sometimes conflict with energy performance and certain degree of customization might be recommended. As is well known, the integration of PV systems into the building envelope can be done through the elements that make up the roof or the façade, but also through the windows by means of semi-transparent photovoltaics and luminescent solar concentrators (LSC). Semi-transparent photovoltaic windows may be used to reduce solar heat gains and generate solar electricity (Bizzarri et al., 2011; Cannavale et al., 2017; Kapsis and Athienitis, 2015; Skandalos et al., 2018). It includes a broad range of PV technologies, from Si- based cells (arranged in such a way as to allow light to pass through the resulting space between the opaque cells) to "see-through" thin films, such as a-Si, CIGS, organic PV, dye sensitized cells and perovskite based solar cells. LSC could provide adaptability to the needs of the architect in that they can be made in a variety of colors, shapes, 
and transparencies, could be made flexible and lightweight (Debije and Verbunt, 2012). In LSC, sunlight penetrate the top surface of a plastic or glass waveguide. This light is absorbed by luminescent molecules (i.e. organic dyes, inorganic phosphors, or quantum dots). The absorbed light is re-emitted at a longer wavelength and a fraction of the re-emitted light is trapped in the waveguide by total internal reflection, becoming concentrated along the edges of the plate. Small PV cells can be attached to the edge of the waveguide to collect the light and convert it to electricity. Applications of LSCs to at least the top $25 \%$ of an office window could provide additional electrical power generation embedded in the building envelope with minimal impact on participant's comfort levels and a limited influence on device performance (Vossen et al., 2016).

In the application of the new methodological framework proposed to BIPV assessment, the first sub-impact, Land use, could be neglected since there is no alteration in the quality of the landscape in an artificial environment built by man such as the city. The sub-impact of the SES would be the most important and influenced by the visibility, but especially by the degree of integration. As the urban space is the daily natural environment of many people, the subjective perception of citizens will also be important. Attachment and identity with the city could lead to rejection of a new installation if it is perceived that the urban aesthetic has worsened. However, studies have shown that well integrated BIPV systems, perceived as an improvement of the urban environment, are appreciated by people in the city centre and with more attachment (Strazzera and Statzu, 2017). In this sense, the possible impact of these systems on the visibility of urban landmarks should be taken into account.

Regarding the visibility, in urban settings, the viewpoint from which the images are taken to carry out the study is of great importance (Kapetanakis et al., 2014). Parameters such as perspective, distance or height must be considered to obtain photographs that faithfully reproduce what the citizen sees (Sánchez-Pantoja et al., 2018). Therefore, images taken from the sky or by using drones from angles or heights that are impossible in the normal movement of people would not be valid. With this in mind, prior results obtained with aerial photographs of PV installations could be questioned (e.g. (Naspetti et al., 2016)).

Similarly, the integration degree, it is obviously an influent factor to assess BIPV impact. However, seeing the lack of consensus in how this factor must be measured, it would be strongly advisable to establish a clear criterion for measuring integration. Good integration and better concealment of the installation from the observer is better valued. Nevertheless, it should be borne in mind that parameters such as the type of professional training of the observer have influenced the aesthetic perception of PV systems, whilst ordinary people was more heterogeneous in likings (Gifford et al., 2000; Naspetti et al., 2016). 
When we refer to BIPV systems, whether the installation is seen, the degree of integration would become the most important factor. A good integration will not only depend on the ability to combine the solar installation with other construction elements but will be influenced by physical characteristics that help to aesthetically harmonise the system with the building, such as colour or texture.

The literature reviewed supports the importance of the colour, which should be definitively taken into account in further research. Attention to harmony and continuity of colour in design phases will be essential if architects and engineers wish to achieve a good integration aesthetically accepted by society. To this aim, it might be interesting to obtain a good visual simulation of the installation, mainly because of the colour and shape (Chiabrando et al., 2011). According with the literature, the best way to work with this parameter seems to be identifying the colour based on the three parameters: hue, saturation and brightness in order to assess the relationship and harmony with the environment. Additionally, matching the digital colour of the picture to the true colour is critical (García et al., 2003).

Additionally, the texture is an interesting factor that, in the case of buildings, is given by the materials used in the envelope. Since the PV integration takes place into the building envelope, this factor will need to be taken into account because, as is well known, the selection of building materials influences for achieving integration with the environment (García et al., 2006). Following the terminology used in the revised literature, it seems more correct to use the term "pattern" when we assess BIPV, among other concepts such as the density of cells or the transparency (Bao et al., 2017; Cerón et al., 2013; Scognamiglio, 2016). Furthermore, special attention should be paid to the distance when taking photographs to assess, since "the influence of the texture is greater in the urban setting, where observer distances are shorter" (García et al., 2006).

With regard to fractality, it must be noticed that all the studies reviewed using this factor are somehow related to nature where the objective was comparing the fractal dimension between built and environmental landscape, or assessing the aesthetic impact into the natural environment. This is reinforced for the concept that fractal dimension is a perceived dimension that can be used to judge the aesthetics of a pattern, and therefore to identify the natural qualities and the naturalness of the pattern (Hagerhall et al., 2004). And also supported by literature which states that fractal analysis is one of the few methods that allows us to quantitatively compare the geometric properties of nature with those of architecture (Vaughan and Ostwald, 2017). We might therefore think that when we analyse the aesthetic impact and liking for photovoltaic integration in buildings, without the intervention of a natural environment, the use of the fractal dimension as an influence factor may not be the most appropriate. However, this factor could be related to patterns analysis when the distribution of the installation, or the shape of the cells, are considered. 
Finally, the third sub-impact, Glare, should also be considered in order to assess BIPV impact. Glare is a very peculiar factor and probably less common in urban environments than in rural ones because of the type of materials used. However, it must be taken into account because if glare does occur, which is normally temporary, it can be very annoying. Current software tools make it possible to calculate and quantify this factor precisely (Ho et al., 2015; Rose and Wollert, 2015). In the case of evaluating BIPV in urban environments, where this problem does not only affect people on the street but can even be annoying for people using nearby buildings through their windows, the calculation should be extended to the façades of buildings that may be affected. Note that in the literature on semi-transparent photovoltaics and LSC, glare is taken in a narrower sense, only as a visual comfort factor for the occupants of the building (Cannavale et al., 2017; Skandalos et al., 2018; Vossen et al., 2016).

To summarize, the aesthetic impact of BIPV systems should be broken down into two sub-impacts: SES, the most important, and Glare. For the SES impact, the visibility and especially the integration degree are the most influential objective factors; however, colour and pattern can help to improve integration. The increasing use of computer tools for this type of study could facilitate the analysis of objective factors together in the future, as has being recently done in some research focused on colour and glare using the concept of visual salience (Xu et al., 2017).

\subsubsection{Application to site location and environmental impact assessment}

The literature provides a large number of examples where GIS are combined with multi-criteria decision-making methods, multi-objective optimization, or probabilistic approaches for site location of SES (Sánchez-Lozano et al., 2016).

Land use is often included in the problem of solving site location as a restriction (Arán et al., 2008; Azevêdo et al., 2017; Borgogno et al., 2015; Sánchez-Lozano et al., 2016; Suuronen et al., 2017). Nevertheless, the sub-impacts and objective factors discussed in this article are usually not considered, with the exception of visibility of SES in (Landscape Institute, 2013; Suuronen et al., 2017).

(Tolli et al., 2016) reviewed 29 projects of renewable energies in Italy with environmental impact assessment reports (EIA), including seven photovoltaic projects, according with the Landscape Character Assessment Guidance for England and Scotland (Tudor, 2014). All the photovoltaic projects considered the visual component of the SES, two take also into consideration the effects on morphological, symbolic and chromatic components, while another also takes into account impact on enjoyment limitation and connotative characteristics.

Perception of the aesthetic impacts through surveys or interviews to understand the viewpoint of the people involved are not usually included in EIA reports of SES projects (Tolli et al., 2016). Predicting human perception based on objective factors 
should fill this gap, especially since in these studies it may be necessary to know the perception of various scenarios in order to select the best option.

Selection of the best sites and environmental impact assessment for the construction of photovoltaic solar farms should provide the least disturbance to the landscape and the appropriate selection of objective factors to improve their aesthetic perception through the three sub-impacts proposed in the framework: Land use, not only as restriction, depending on size and quality of the land use; SES, depending on visibility and degree of integration; and Glare, depending on visibility. Moreover, integration of other methods to estimate visibility based on its observability (Fernandez-Jimenez et al., 2015; García-Garrido et al., 2012) and glare risk (Ho et al., 2015; Rose and Wollert, 2015) with current GIS-based methods should lead to results to improve the aesthetic perception of the inhabitants of the zone.

\subsection{Conclusion}

In this article, a theoretical review of the objective factors, methods and analyses performed in the field of aesthetic impact assessment of the SES integration has been carried out. On the one hand, a clear lack of consensus has been detected in the application of objective factors and methodologies. On the other hand, bearing in mind the importance of relating objective factors with the subjective assessment of the observer, no one has ever established a clear relationship between both issues when evaluating the aesthetic impact of solar installations.

Objective factors have been classified in two groups: one with the simple and independent ones, and other with the complex and dependent ones. Our main contribution is the establishment of the most influential objective factors based on the revised literature that, coinciding with the more complex ones, are visibility (or size) and degree of integration. As a result, a methodological qualitative framework is proposed with the intention of offering a working basis for future research. In the methodological framework the aesthetic impact is broken down into three levels or sub-impacts: Land use, which depends on the size; SES, which depends on visibility and degree of integration and Glare, which depends on visibility.

For practical purposes, and assuming the limitation that the proposed framework is based on literature, visibility and integration degree are the objective factors that should be given the most attention by the technicians in the design phase of a SES. To minimise this impact, or even to make it negative (perceived as positive by the observer), it will be necessary to study simpler factors such as colour, shape or texture in order to achieve greater visual continuity with the environment or, in any case, aesthetically acceptable contrasts. In the special case of on-ground systems in rural environments, it will be necessary to make a prior analysis of the location in order to minimize the impact caused by land use. 
The aesthetic impact of BIPV systems should be broken down into two sub-impacts: SES and Glare. For the SES impact, the visibility and especially the integration degree are the most influential objective factors. In addition, colour and pattern can help to improve integration.

For site location and EIA of SES, the three sub-impacts should be considered. Moreover, integration of other methods to estimate visibility based on its observability and glare risk with current GIS-based methods should lead to results to improve the aesthetic perception of the inhabitants of the zone.

For further research, interesting alternatives already used in other fields about perceptions and emotions such as methods based on fuzzy, cognitive maps, intelligent agents, $\mathrm{CNN}$, etc. could be useful and relevant for the aesthetic assessment of SES.

This research did not receive any specific grant form funding agencies in the public, commercial, or nor-for-profit sectors.

\section{REFERENCES}

Anurag, A., Zhang, J., Gwamuri, J., Pearce, J.M., 2017. General design procedures for airportbased solar photovoltaic systems. Energies 10, 1-19. https://doi.org/10/gbtnhw

Arán, J., Espín, A., Aznar, F., Zamorano, M., Rodríguez, M., Ramos, A., 2008. Environmental decision-support systems for evaluating the carrying capacity of land areas: Optimal site selection for grid-connected photovoltaic power plants. Renew. Sustain. Energy Rev. https://doi.org/10/bwrg39

Atkinson, C., Sansom, C.L., Almond, H.J., Shaw, C.P., 2015. Coatings for concentrating solar systems - A review. Renew. Sustain. Energy Rev. 45, 113-122. https://doi.org/10/dr7d

Azevêdo, V.W.B., Candeias, L.B., Tiba, C., 2017. Location study of solar thermal power plant in the state of Pernambuco using geoprocessing technologies and Multiple-Criteria analysis. Energies 10, 1042. https://doi.org/10/gbsk7z

Bao, Q., Honda, T., El Ferik, S., Shaukat, M.M., Yang, M.C., 2017. Understanding the role of visual appeal in consumer preference for residential solar panels. Renew. Energy 113, 1569-1579. https://doi.org/10/drwt

Barrett, L.F., Bar, M., 2009. See it with feeling: affective predictions during object perception. Philos. Trans. R. Soc. Lond. B. Biol. Sci. 364, 1325-34. https://doi.org/10/d7h5qt

Bell, S., 1999. Landscape: Pattern, Perception and Process, First. ed. London: E\&FN Spon, Oxon.

Bennett, E.M., Cramer, W., Begossi, A., Cundill, G., Díaz, S., Al., E., 2015. Linking biodiversity, ecosystem services, and human well-being: three challenges for designing research for sustainability. Curr. Opin. Environ. Sustain. https://doi.org/10/f3pcz7

Berghman, M., Hekkert, P., 2017. Towards a unified model of aesthetic pleasure in design. 
New Ideas Psychol. 47, 136-144. https://doi.org/10/dr7f

Beylot, A., Payet, J.Ô., Puech, C., Adra, N., Jacquin, P., Blanc, I., Beloin-Saint-Pierre, D., 2014. Environmental impacts of large-scale grid-connected ground-mounted PV installations. Renew. Energy 61, 2-6. https://doi.org/10/drwx

Bishop, I., Dartnell, P., Davie, S., Drew, J., McDonald, T., 1990. Object, environment and observer related variables in the visual effect of electricity transmission lines. Landsc. Aust.

Bishop, I.D., 1997. Testing perceived landscape colour difference using the Internet. Landsc. Urban Plan. 37, 187-196. https://doi.org/10/djhmvj

Bizzarri, G., Gillott, M., Belpoliti, V., 2011. The potential of semitransparent photovoltaic devices for architectural integration: The development of device performance and improvement of the indoor environmental quality and comfort through case-study application. Sustain. Cities Soc. 1, 178-185. https://doi.org/10/dhxxdd

Borgogno, E., Fabrizio, E., Chiabrando, R., 2015. Site selection of large ground-mounted photovoltaic plants: A GIS decision support system and an application to Italy. Int. J. Green Energy 12, 515-525. https://doi.org/10/dr7g

Botelho, A., Lourenço-Gomes, L., Pinto, L., Sousa, S., Valente, M., 2017. Accounting for local impacts of photovoltaic farms: The application of two stated preferences approaches to a case-study in Portugal. Energy Policy 109, 191-198. https://doi.org/10/gb4tnh

Bovill, C., 1996. Fractal Geometry in Architecture and Design. Design Science Collection. https://doi.org/10/b5r7sj

Brachmann, A., Redies, C., 2017. Computational and experimental approaches to visual aesthetics. Front. Comput. Neurosci. 11, 102. https://doi.org/10/gcmnv8

Bradley, M.M., Codispoti, M., Cuthbert, B.N., Lang, P.J., 2001. Emotion and motivation I: defensive and appetitive reactions in picture processing. Emotion 1, 300-319. https://doi.org/10/d7tq64

Bradley, M.M., Lang, P.J., 2000. Measuring emotion: Behavior, feeling, and physiology, in: Cognitive Neuroscience of Emotion. Oxford.

Bradley, M.M., Lang, P.J., 1994. Measuring emotion: The self-assessment manikin and the semantic differential. J. Behav. Ther. Exp. Psychiatry 25, 49-59. https://doi.org/10/bx59sf

Braun, J., Amirshahi, S.A., Denzler, J., Redies, C., 2013. Statistical image properties of print advertisements, visual artworks and images of architecture. Front. Psychol. 4, 1-15. https://doi.org/10/gbfpvz

Cacioppo, J.T., Berntson, G., Larsen, J., Poehlmann, K.M., Ito, T.A., 2000. The Psychophysiology of Emotion, in: The Handbook of Emotion. New York: Guilford Press., pp. 173-191.

Cai, J., Qi, L., 2015. Recent advances in antireflective surfaces based on nanostructure arrays. 
Mater. Horizons 2, 37-53. https://doi.org/10/dr7j

Cannavale, A., Hörantner, M., Eperon, G.E., Snaith, H.J., Fiorito, F., Ayr, U., Martellotta, F., 2017. Building integration of semitransparent perovskite-based solar cells: Energy performance and visual comfort assessment. Appl. Energy 194, 94-107. https://doi.org/10/f96h22

Carlson, A., 2001. Aesthetic preferences for sustainable landscapes: seeing and knowing. For. Landscapes. New York CABI Publ. 31-42.

Carlucci, S., Causone, F., De Rosa, F., Pagliano, L., 2015. A review of indices for assessing visual comfort with a view to their use in optimization processes to support building integrated design. Renew. Sustain. Energy Rev. https://doi.org/10/ggcdqp

Cerón, I., Caamaño-Martín, E., Neila, F.J., 2013. 'State-of-the-art' of building integrated photovoltaic products. Renew. Energy 58, 127-133. https://doi.org/10/drw3

Chen, H.Q., Honda, T., Yang, M.C., 2013. Approaches for identifying consumer preferences for the design of technology products: a case study of residential solar panels. J. Mech. Des. 135, 061007. https://doi.org/10/gbdzzs

Chiabrando, R., Fabrizio, E., Garnero, G., 2011. On the applicability of the visual impact assessment OAISPP tool to photovoltaic plants. Renew. Sustain. Energy Rev. 15, 845850. https://doi.org/10/bdkjr8

Chiabrando, R., Fabrizio, E., Garnero, G., 2009. The territorial and landscape impacts of photovoltaic systems: Definition of impacts and assessment of the glare risk. Renew. Sustain. Energy Rev. 13, 2441-2451. https://doi.org/10/fb3464

Damasio, A., Carvalho, G.B., 2013. The nature of feelings: evolutionary and neurobiological origins. Nat. Rev. Neurosci. 14, 143-152. https://doi.org/10/gfsqmf

Daniel, T.C., 2001. Whither scenic beauty? Visual landscape quality assessment in the 21st century. Landsc. Urban Plan. 54, 267-281. https://doi.org/10/fbwznr

Debije, M.G., Verbunt, P.P.C., 2012. Thirty years of luminescent solar concentrator research: solar energy for the built environment. Adv. Energy Mater. 2, 12-35. https://doi.org/10/cmfvr3

Delfanti, L., Colantoni, A., Recanatesi, F., Bencardino, M., Sateriano, A., Zambon, I., Salvati, L., 2016. Solar plants, environmental degradation and local socioeconomic contexts: A case study in a Mediterranean country. Environ. Impact Assess. Rev. 61, 88-93. https://doi.org/10/drw7

Denzler, J., Rodner, E., Simon, M., 2016. Convolutional neural networks as a computational model for the underlying processes of aesthetics perception, in: Lecture Notes in Computer Science (Including Subseries Lecture Notes in Artificial Intelligence and Lecture Notes in Bioinformatics). Springer, Cham, pp. 871-887. https://doi.org/10/dr7k

Dubey, S., Jadhav, N.Y., Zakirova, B., 2013. Socio-economic and environmental impacts of silicon based photovoltaic (PV) technologies. Energy Procedia 33, 322-334. https://doi.org/10/drw8 
Eerola, T., Vuoskoski, J.K., Kautiainen, H., 2016. Being moved by unfamiliar sad music is associated with high empathy. Front. Psychol. 7, 1176. https://doi.org/10/f84bpr

EU, 2000. European Landscape Convention (No. ETS no. 176).

Falomir, Z., Museros, L., Sanz, I., Gonzalez-Abril, L., 2018. Categorizing paintings in art styles based on qualitative color descriptors, quantitative global features and machine learning (QArt-Learn). Expert Syst. Appl. 97, 83-94. https://doi.org/10/dr7m

Fernandez-Jimenez, L.A., Mendoza-Villena, M., Zorzano-Santamaria, P., Garcia-Garrido, E., Lara-Santillan, P., et, 2015. Site selection for new PV power plants based on their observability. Renew. Energy 78, 7-15. https://doi.org/10/f67db8

Forsythe, A., Nadal, M., Sheehy, N., Cela-Conde, C.J., Sawey, M., 2011. Predicting beauty: fractal dimension and visual complexity in art. Br. J. Psychol. 102, 49-70. https://doi.org/10/bzb32n

Frijda, N.H., 1988. The laws of emotion. Am. Psychol. 43, 349-358. https://doi.org/10/ckq

Galindo, M., Rodríguez, J., 2000. Environmental aesthetics and psychological wellbeing: relationships between preference judgements for urban landscapes and other relevant affective responses. Psychol. Spain 4, 13-27.

García-Garrido, E., Lara-Santillán, P., Zorzano-Alba, E., Mendoza-Villena, M., ZorzanoSantamaría, P., Fernández-Jiménez, L.A., Falces, A., 2012. Visual impact assessment for small and medium size PV plants, in: Advances in Power and Energy Systems. Prague, pp. 57-61.

García, L., Hernández, J., Ayuga, F., 2006. Analysis of the materials and exterior texture of agro-industrial buildings: a photo-analytical approach to landscape integration. Landsc. Urban Plan. 74, 110-124. https://doi.org/10/d63zbq

García, L., Hernández, J., Ayuga, F., 2003. Analysis of the exterior colour of agroindustrial buildings: a computer aided approach to landscape integration. J. Environ. Manage. 69, 93-104. https://doi.org/10/b7xvc8

Gerger, G., Leder, H., Kremer, A., 2014. Context effects on emotional and aesthetic evaluations of artworks and IAPS pictures. Acta Psychol. (Amst). 151, 174-183. https://doi.org/10/f6h5gt

Gifford, R., Hine, D.W., Muller-Clemm, W., D’Arcy J Reynolds, J., Shaw, K.T., 2000. Decoding modern architecture. A lens model approach for understanding the aesthetic differences of architects and laypersons. Environ. Behav. 32, 163-187.

Gross, J.J., 2007. Handbook of emotion regulation. Guilford Press, New York.

Gunerhan, H., Hepbasli, A., Giresunlu, U., 2008. Environmental impacts from the solar energy systems. Energy Sources, Part A Recover. Util. Environ. Eff. 31, 131-138. https://doi.org/10/fpvvss

Hagerhall, C.M., Purcell, T., Taylor, R., 2004. Fractal dimension of landscape silhouette outlines as a predictor of landscape preference. J. Environ. Psychol. 24, 247-255. 
https://doi.org/10/d7svxw

Hanaei, H., Assadi, M.K., Saidur, R., 2016. Highly efficient antireflective and self-cleaning coatings that incorporate carbon nanotubes (CNTs) into solar cells: A review. Renew. Sustain. Energy Rev. https://doi.org/10/dr7q

Hedayati, M.K., Elbahri, M., 2016. Antireflective coatings: Conventional stacking layers and ultrathin plasmonic metasurfaces, a mini-review. Materials (Basel). 9, 22. https://doi.org/10/f8tzc7

Hernandez, R.R., Easter, S.B., Murphy-Mariscal, M.L., Maestre, F.T., Tavassoli, M., et al., 2014. Environmental impacts of utility-scale solar energy. Renew. Sustain. Energy Rev. https://doi.org/10/f5ps68

Ho, C.K., Sims, C.A., Yellowhair, J.E., Bush, E., 2015. Solar Glare Hazard Analysis Tool (SGHAT).

Hull, R.B., Stewart, W., 1992. Validity of photo-based scenic beauty judgments. J. Environ. Psychol. 12, 101-114. https://doi.org/10/cxznzz

Kao, Y., He, R., Huang, K., 2017. Deep aesthetic quality assessment with semantic information. IEEE Trans. Image Process. 26, 1482-1495. https://doi.org/10/f9t5sw

Kapetanakis, I.A., Kolokotsa, D., Maria, E.A., 2014. Parametric analysis and assessment of the photovoltaics' landscape integration: Technical and legal aspects. Renew. Energy 67, 207-214. https://doi.org/10/f52cws

Kaplan, R., Kaplan, S., 1989. The experience of nature. A psychological perspective. Cambridge University Press, New York.

Kapsis, K., Athienitis, A.K., 2015. A study of the potential benefits of semi-transparent photovoltaics in commercial buildings. Sol. Energy 115, 120-132. https://doi.org/10/f7d75j

Koellner, T., de Baan, L., Beck, T., Brandão, M., Civit, B., et al., 2013. UNEP-SETAC guideline on global land use impact assessment on biodiversity and ecosystem services in LCA. Int. J. Life Cycle Assess. 18, 1188-1202. https://doi.org/10/f3p7h4

Kowalczuk, Z., Czubenko, M., 2016. Computational approaches to modeling artificial emotion - An overview of the proposed solutions. Front. Robot. Al 3, 21. https://doi.org/10/dr77

Küller, R., 1979. A semantic test for use in cross-cultural studies. Man-Environment Syst. 9, 253-256.

Kumar, H., Anand, V., Sreekumaran, A., Ramakrishna, S., 2011. Anti-reflective coatings: A critical, in-depth review. Energy Environ. Sci. 4, 3779-3804. https://doi.org/10/d3wxwt

Lakhani, R., Doluweera, G., Bergerson, J., 2014. Internalizing land use impacts for life cycle cost analysis of energy systems: A case of California's photovoltaic implementation. Appl. Energy 116, 253-259. https://doi.org/10/f5tfwr

Landscape Institute, 2013. Guidelines for landscape and visual impact assessment, 3rd ed. Routledge. 
Lang, P.J., 1988. What are the data of emotion?, in: Hamilton, V., Bower, G.H., Frijda, N.H. (Eds.), Cognitive Perspectives on Emotion and Motivation. Kluwer Academic Publishers, Dordrecht, pp. 173-191. https://doi.org/10/drxb

Lang, P.J., Bradley, M.M., Cuthbert, B.N., 1997. Motivated attention: Affect, activation, and action., in: Attention and Orienting : Sensory and Motivational Processes. Lawrence Erlbaum Associates, pp. 97-135.

Larsen, R.J., Prizmic-Larsen, Z., 2006. Measuring emotions: Implications of a multimethod perspective., in: Handbook of Multimethod Measurement in Psychology. American Psychological Association, Washington, pp. 337-351. https://doi.org/10/b9xc5j

Lazarus, R.S., 1991. Emotion and adaptation. Oxford University Press, Oxford.

Lindeijer, E., 2000. Review of land use impact methodologies. J. Clean. Prod. 8, 273-281. https://doi.org/10/d4jmp5

Lothian, A., 1999. Landscape and the philosophy of aesthetics: is landscape quality inherent in the landscape or in the eye of the beholder? Landsc. Urban Plan. 44, 177-198. https://doi.org/10/bzszrz

Lu, M., Lin, A., Sun, J., 2018. The impact of photovoltaic applications on urban landscapes based on visual Q methodology. Sustainability 10, 1-15. https://doi.org/10/gdr52n

Lu, X., Lin, Z., Jin, H., Yang, J., Wang, J.Z., 2015. Rating image aesthetics using deep learning. IEEE Trans. Multimed. 17, 2021-2034. https://doi.org/10/f7w4bm

MacDonald, E.F., Gonzalez, R., Papalambros, P., 2009. The construction of preferences for crux and sentinel product attributes. J. Eng. Des. 20, 609-626. https://doi.org/10/d9f6sv

Mandelbrot, B.B., 1982. The fractal geometry of nature. San Francisco, CA.

Mauss, I.B., Robinson, M.D., 2009. Measures of emotion: A review. Cogn. Emot. 23, 209-237. https://doi.org/10/fj2s3g

McKeown, B., Thomas, D., 2013. Q Methodology, Second. ed. SAGE Publications.

Mehrabian, A., Russell, J.A., 1974. An approach to environmental psychology, Cambridge Mass The MIT Press.

Mérida-Rodríguez, M., Lobón-Martín, R., Perles-Roselló, M., 2015. The production of solar photovoltaic power and its landscape dimension, in: Renewable Energies and European Landscapes. Springer Netherlands, Dordrecht, pp. 255-277. https://doi.org/10/drxf

Millennium Ecosystem Assessment, 2005. Ecosystems and Human Well-Being:Opportunities and Challenges for Business and Industry.

Mureika, J.R., 2005. Fractal dimensions in perceptual color space: A comparison study using Jackson Pollock's art. Chaos 15. https://doi.org/10/bsd27j

Nasar, J.L., 1992. Environmental aesthetics: Theory, research, and application. Cambridge University Press. 
Naspetti, S., Mandolesi, S., Zanoli, R., 2016. Using visual Q sorting to determine the impact of photovoltaic applications on the landscape. Land use policy 57, 564-573. https://doi.org/10/drxg

Nohl, W., 2001. Sustainable landscape use and aesthetic perception - preliminary reflections on future landscape aesthetics. Landsc. Urban Plan. 54, 223-237. https://doi.org/10/fh2xh2

Osgood, C.E., 1962. Studies on the generality of affective meaning systems. Am. Psychol. 17, 10-28. https://doi.org/10/c4vj88

Pachaki, C., 2003. Agricultural landscape indicators: a suggested approach for the scenic value., in: Dramstad, W., Sogge, C. (Eds.), OCDE, Agricultural Impacts on Landscapes: Developing Indicators for Policy Analysis. pp. 240-250.

Plieninger, T., Kizos, T., Bieling, C., Dû-Blayo, L. Le, Budniok, M.-A., et al., 2015. Exploring ecosystem-change and society through a landscape lens: recent progress in European landscape research. Ecol. Soc. 20 (2). https://doi.org/10/f3nc5p

Rodrigues, M., Montañés, C., Fueyo, N., 2010. A method for the assessment of the visual impact caused by the large-scale deployment of renewable-energy facilities. Environ. Impact Assess. Rev. 30, 240-246. https://doi.org/10/cw4rzq

Rose, T., Wollert, A., 2015. The dark side of photovoltaic - 3D simulation of glare assessing risk and discomfort. Environ. Impact Assess. Rev. 52, 24-30. https://doi.org/10/f664v6

Ruesch, F., Bohren, A., Battaglia, M., Brunold, S., 2016. Quantification of glare from reflected sunlight of solar installations, in: Energy Procedia. Elsevier, pp. 997-1004. https://doi.org/10/dr8b

Russell, J.A., Pratt, G., 1980. A description of the affective quality attributed to environments. J. Pers. Soc. Psychol. 38, 311-322. https://doi.org/10/d33dqm

Sánchez-Lozano, J.M., García-Cascales, M.S., Lamata, M.T., 2016. Comparative TOPSISELECTRE TRI methods for optimal sites for photovoltaic solar farms. Case study in Spain. J. Clean. Prod. 127, 387-398. https://doi.org/10/f8qznn

Sánchez-Pantoja, N., Vidal, R., Pastor, M.C., 2018. Aesthetic perception of photovoltaic integration within new proposals for ecological architecture. Sustain. Cities Soc. 39, 203-214. https://doi.org/10/gdr37n

Scherer, K.R., 1984. Emotion as a multicomponent process: A model and some cross-cultural data. Rev. Personal. Soc. Psychol. 5, 37-63.

Schindler, I., Hosoya, G., Menninghaus, W., Beermann, U., Wagner, V., Eid, M., Scherer, K.R., 2017. Measuring aesthetic emotions: A review of the literature and a new assessment tool. PLoS One 12. https://doi.org/10/gbgrn5

Scognamiglio, A., 2016. "Photovoltaic landscapes": Design and assessment. A critical review for a new transdisciplinary design vision. Renew. Sustain. Energy Rev. 55, 629-661. https://doi.org/10/drxw 
Scruton, R., 2013. The aesthetics of architecture. Princeton University Press.

ShuttleworthS., 1980. The use of photographs as an environment presentation medium in landscape studies. J. Environ. Manage. 11.

Silvia, P.J., 2005. Emotional responses to art: from collation and arousal to cognition and emotion. Rev. Gen. Psychol. 9, 342-357. https://doi.org/10/ch388q

Silvia, P.J., Fayn, K., Nusbaum, E.C., Beaty, R.E., 2015. Openness to experience and awe in response to nature and music: Personality and profound aesthetic experiences. Psychol. Aesthetics, Creat. Arts 9, 376-384. https://doi.org/10/dr8f

Skandalos, N., Karamanis, D., Peng, J., Yang, H., 2018. Overall energy assessment and integration optimization process of semitransparent PV glazing technologies. Prog. Photovoltaics Res. Appl. 26, 473-490. https://doi.org/10/gdswrt

Stamps, A.E., 2002. Fractals, skylines, nature and beauty. Landsc. Urban Plan. 60, 163-184. https://doi.org/10/fk35q3

Stamps, A.E., 1999. Physical determinants of preferences for residential facades. Environ. Behav. 31, 723-751. https://doi.org/10/d2p96t

Strazzera, E., Statzu, V., 2017. Fostering photovoltaic technologies in Mediterranean cities: Consumers' demand and social acceptance. Renew. Energy 102, 361-371. https://doi.org/10/f9hmhh

Suuronen, A., Lensu, A., Kuitunen, M., Andrade-Alvear, R., Celis, N.G., et al., 2017. Optimization of photovoltaic solar power plant locations in northern Chile. Environ. Earth Sci. 76, 824. https://doi.org/10/gctbzr

Tolli, M., Recanatesi, F., Piccinno, M., Leone, A., 2016. The assessment of aesthetic and perceptual aspects within environmental impact assessment of renewable energy projects in Italy. Environ. Impact Assess. Rev. 57, 10-17. https://doi.org/10/f8gp63

Torres-Sibille, A.C., Cloquell-Ballester, Vicente-A., Cloquell-Ballester, Víctor-A., Artacho, M.A., 2009. Aesthetic impact assessment of solar power plants: An objective and a subjective approach. Renew. Sustain. Energy Rev. 13, 986-999. https://doi.org/10/c4xh7r

Torres-Sibille, A.C., Cloquell-Ballester, Víctor-A, Cloquell-Ballester, Vicente-A, Darton, R., 2007. Development and validation of a multicriteria indicator for the assessment of objective aesthetic impact of wind farms. Renew. Sustain. Energy Rev. 13, 40-66. https://doi.org/10/bqmxkg

Tudor, C., 2014. An approach to landscape character assessment, Natural England. Natural England.

Turney, D., Fthenakis, V., 2011. Environmental impacts from the installation and operation of large-scale solar power plants. Renew. Sustain. Energy Rev. 15, 3261-3270. https://doi.org/10/cxxbqb

Tveit, M., Ode, Å., Fry, G., 2006. Key concepts in a framework for analysing visual landscape character. Landsc. Res. 31, 229-255. https://doi.org/10/b7pvxd 
Ulrich, R.S., 1986. Human responses to vegetation and landscapes. Landsc. Urban Plan. 13, 29-44. https://doi.org/10/drs775

Ulrich, R.S., Simons, R.F., Losito, B.D., Fiorito, E., Miles, M.A., Zelson, M., 1991. Stress recovery during exposure to natural and urban environments. J. Environ. Psychol. 11, 201-230. https://doi.org/10/csp47k

van den Berg, A.E., Koole, S.L., van der Wulp, N.Y., 2003. Environmental preference and restoration: (How) are they related? J. Environ. Psychol. 23, 135-146. https://doi.org/10/fb38n3

van Etteger, R., Thompson, I.H., Vicenzotti, V., 2016. Aesthetic creation theory and landscape architecture. J. Landsc. Archit. 11, 80-91. https://doi.org/10/f3vhdf

Vaughan, J., Ostwald, M.J., 2017. The comparative numerical analysis of nature and architecture: A new framework. Int. J. Des. Nat. Ecodynamics 12, 156-166. https://doi.org/10/dr8j

von Möllendorff, C., Welsch, H., 2017. Measuring renewable energy externalities: evidence from subjective well-being data. Land Econ. 93, 109-126. https://doi.org/10/dr8k

Vossen, F.M., Aarts, M.P.J., Debije, M.G., 2016. Visual performance of red luminescent solar concentrating windows in an office environment. Energy Build. 113, 123-132. https://doi.org/10/f8djsx

Wiser, R., Millstein, D., Mai, T., Macknick, J., Carpenter, A., et al., 2016. The environmental and public health benefits of achieving high penetrations of solar energy in the United States. Energy 113, 472-486. https://doi.org/10/f883sh

Wohlwill, J.F., 1976. Environmental aesthetics: the environment as a source of affect, in: Human Behavior and Environment. Springer US, Boston, MA, pp. 37-86. https://doi.org/10/drx4

Xu, R., Wittkopf, S., Roeske, C., 2017. Quantitative evaluation of BIPV visual impact in building retrofits using saliency models. Energies 10, 668. https://doi.org/10/dr8m

Yao, L., He, J., 2014. Recent progress in antireflection and self-cleaning technology - From surface engineering to functional surfaces. Prog. Mater. Sci. 61, 94-143. https://doi.org/10/f5snzg

Zangwill, N., 2007. Aesthetic creation. Oxford University Press.

Zhai, P., Williams, E., 2012. Analyzing consumer acceptance of photovoltaics (PV) using fuzzy logic model. Renew. Energy 41, 350-357. https://doi.org/10/djknkv

Zoellner, J., Schweizer-Ries, P., Wemheuer, C., 2008. Public acceptance of renewable energies: Results from case studies in Germany. Energy Policy 36, 4136-4141. https://doi.org/10/fbcz5t 


\title{
CAPÍtulo 3.
}

\section{AESTHETIC PERCEPTION OF PHOTOVOLTAIC INTEGRATION WITHIN NEW PROPOSALS FOR ECOLOGICAL ARCHITECTURE}

\author{
Núria Sánchez-Pantoja ${ }^{\mathrm{a}}$, Rosario Vidal ${ }^{\mathrm{a}}$, M. Carmen Pastor ${ }^{\mathrm{b}}$ \\ a Department of Mechanical Engineering and Construction, GID, Universitat Jaume I, Av. Sos \\ Baynat s/n, 12071 Castellón, Spain. \\ b Department of Basic and Clinical Psychology, and Psychobiology, Universitat Jaume I, Av. \\ Sos Baynat s/n, 12071 Castellón, Spain.
}

Corresponding author: Núria Sánchez-Pantoja Tel: +34 964729252.

Email: nbelengu@uji.es. Postal address: Department of Mechanical Engineering and Construction, Universitat Jaume I, Av. Sos Baynat s/n, 12071 Castellón, Spain.

\section{ABSTRACT}

Architecture has become an important field of research on the mitigation of climate change. The literature contains a number of environmental studies of buildings and energy efficiency improvements analysis. Important advances have also been made by integrating renewable energies within the building envelope. In architecture, however, it must be remembered that the formal aspect is as important as the functional one, and therefore rating the aesthetic perception of these new technologies is very interesting to better integrate more sustainable technologies in the city. This work focuses on the real opinion of the citizens about the aesthetic impact resulting from the use of photovoltaic systems in buildings. A survey was conducted using the Self-Assessment Manikin (SAM) to evaluate the feelings through two classic dimensions of affect: hedonic valence (pleasant-unpleasant) and arousal (activation or emotional intensity). Overall, results (error range of 5\%) show that all the prototypes were rated positively and with a medium level of arousal, although the integrated systems obtained higher values in both dimensions of affect. The degree of appreciation of the installation by the observer has proved to be a powerful factor. On a socio-demographic level, respondents' age was observed as an influential factor in these subjective evaluations.

KEYWORDS

Photovoltaic integration, aesthetic perception, SAM, BIPV, BAPV, SDE 2014. 


\subsection{Introduction}

Architecture, as a discipline, has undergone very significant changes in recent years. Apart from aesthetic factors or the innovative and challenging architectural designs frequently offered by the world's most renowned architects, the construction of buildings has become an important field of research investigating ways to mitigate climate change. Terms such as bioclimatic design, sustainable construction, energy efficiency and environment-friendly or natural materials are associated with the latest advances in an architecture that strives to adapt increasingly better to a more sustainable global development.

The literature contains studies which include environmental assessment as a means to help architects in their search for materials and construction solutions that guarantee the development of buildings that generate a lower environmental impact. The Life Cycle Assessment (LCA) methodology has been used in a number of studies as a tool that allows the calculation of environmental impacts and, therefore, the comparison of different aspects ranging from specific materials to whole buildings, including the entire construction process, the use phase and even the end of life of the building (Azzouz et al., 2017; Bastos et al., 2014; Bonomo et al., 2017; Buyle et al., 2013; Cabeza et al., 2014; Ghattas et al., 2013; Hemmerle \& Hemmerle, 2016; Ortiz et al., 2009; Ramesh et al., 2010; Sagani et al., 2017; Werner \& Richter, 2007; Zabalza Bribián et al., 2009, 2011). Many studies have shown that the greatest environmental impacts are produced during the use phase of the building, as this is the one with the greatest energy consumption (Azzouz et al., 2017; Ghattas et al., 2013; Peuportier, 2001; Ramesh et al., 2010), mainly due to the use of heating and air conditioning, household appliances and lighting. It therefore follows that a significant part of the research conducted focuses on reducing the impacts during this phase.

One possible way to lower the impact is to directly reduce the energy consumption of the building, which depends on a number of factors such as the construction solutions, the climatic conditions of the area where it is located and the type of installations the building is equipped with. A second way, however, consists in using renewable energy sources. This has led to a significant increase in the use of photovoltaic energy over the last 20 years, both in Spain and in Europe as a whole. Initially, this technology was implemented in the form of "solar farms" integrated within rural areas, which occasionally modified a landscape that had remained practically unaltered for years except for the introduction of extensive agriculture (Torres-Sibille et al., 2009). Yet, the requirements set out in increasingly more sustainable European and worldwide policies have gradually led to the presence of these facilities within the urban landscape, mainly in the form of systems for capturing solar power, which today generate a significant part of the European energy supply. The European Union has launched a plan to create an Energy Union to ensure a safe, affordable supply while also respecting the climate. The goals of this 
plan require that $20 \%$ of the energy must be obtained from renewable sources by 2020 and $27 \%$ by 2030 . The advances being made in this sense are considered to be positive, as the quota of renewable energy rose from $8.5 \%$ in 2005 to $14.1 \%$ in 2012, according to figures from the European Commission. The scope of these goals nevertheless requires an active commitment by both the industrial and the residential sectors as regards the use of renewable energies.

In different European countries, the building regulations demand an increasingly significant application of this kind of installations, which are starting to become common features in the urban landscape. An example of this is the Technical Building Code in Spain (Gobierno de España, 2013), which requires the installation of photovoltaic systems in industrial buildings and thermal systems in those for residential use. Hence, energy efficiency improvement systems - especially those capturing solar power - are today considered just another element of buildings.

A great deal of research has been conducted within the field of photovoltaic technology in recent decades, but its integration within urban environments has only been seen as an interesting proposition in the last 5-10 years. The earliest studies basically investigated the energy potential of the installations, focusing on the areas of the roofs of buildings and their capacity to house photovoltaic installations. The main aim of these studies was to optimise the installations from the point of view of energy efficiency. To do so, they analysed the different existing technologies and their suitability in different climates and urban settings. Examples of such work include the review conducted by Makrides and collaborators (Makrides et al., 2013, 2012, 2010; Vivar et al., 2014) or studies that analysed the conditions produced in shaded areas in the urban setting (D'Orazio et al., 2013; Loulas et al., 2012).

One factor that is considered important in several studies is the repercussion of the economic cost of installing photovoltaic systems for the whole building (Bonomo et al., 2017; Hemmerle and Hemmerle, 2016; Sagani et al., 2017; Yang and Zou, 2016). And a recent study even states that, in order to decide whether to incorporate a PV system into the building, the main motivation is personal economic benefit ahead of the contribution to environmental protection (Fleiß et al., 2017). It must be remembered, however, that the use of these systems in the building envelope falls within the field of architecture, and hence, not only the efficiency and cost of the installation are important but the aesthetic also plays a very important role. The acceptance of this new technology by citizens, as users of the city, is today a topic of growing interest that can be an invaluable aid in designing these installations in the future. The integration of photovoltaic technology in buildings has a great potential for application if it is addressed as of the design phase of the building (Johnston, 2007). Conversely, installing these systems at the end of the process involves a higher economic cost and results in an aesthetically less attractive building. The literature contains several studies that, without analysing the users' perception at the aesthetic level, do evaluate people's acceptance and even their willingness to use photovoltaic 
systems that are integrated within the envelope (Lim et al., 2009; Radmehr et al., 2014). These studies conclude that, in order to raise people's awareness regarding the use of photovoltaic technology in buildings, it is necessary to find a way to apply them without upsetting the aesthetic of the façade. How the elements of the installation are introduced into the building envelope is therefore of great importance.
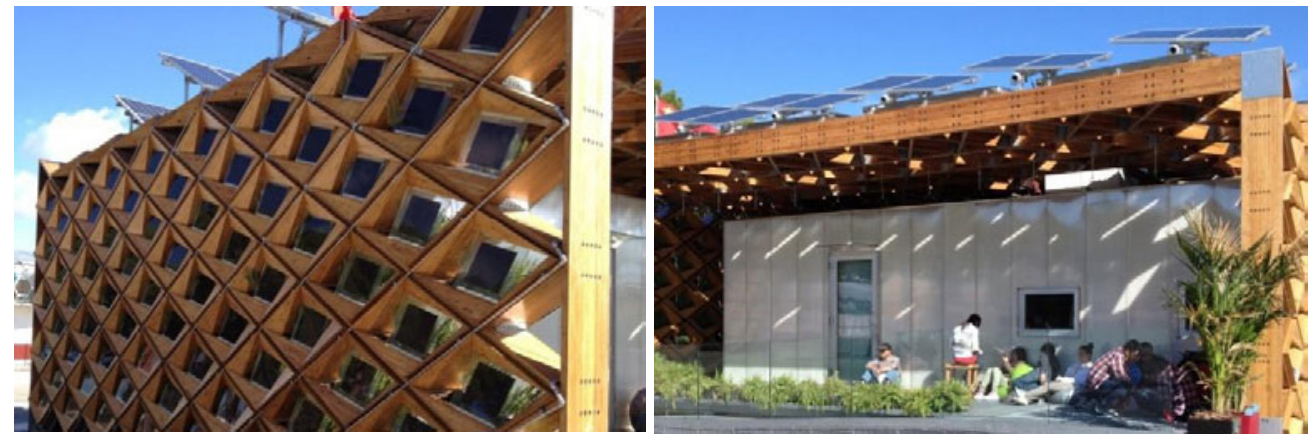

Fig. 3. 1 The Eco-House prototype exhibited at SDE 2012. BIPV systems are used in the façade and BAPV on the roof.

Depending on the way the photovoltaic technology installations used in the envelope are fitted they can be classified as BIPV (Building-integrated photovoltaics, which are totally integrated within the building envelope) or BAPV (Building-applied photovoltaics, which are mounted upon a metallic support structure on the roof of the building) (see Fig. 3. 1).

In the case of BAPV, no special interest is given to the aesthetic integration of the system and priority is generally granted to its ability to capture solar radiation. The type of installation and its location (normally on the roof) are often decided at an advanced stage of the project or even after it has finished, being the resulting less aesthetically attractive and less closely linked to architectural design. The use of BIPV technology, in contrast, requires technical planners to consider the installation from the initial phase of the design of the building in order to achieve a good aesthetic integration within the building as a whole. The use of this technology is becoming more popular as the wide range of possibilities for integrating it become known to architects and builders (Henemann, 2008) and some researchers and architects are devoting part of their work to exhibiting the state-of-the-art of BIPV products (Cerón et al., 2013; Petter et al., 2012). As some authors conclude (Athienitis and Candanedo, 2010; Michael et al., 2010), if special innovative designs are used, in some cases such integration could require a higher initial economic investment, but other studies confirm the long-term economic advantages of using BIPV systems (Portolan dos Santos and Rüther, 2012). The development of this type of photovoltaic systems and their capacity for integration within architecture is an ongoing field of research, both for the scientific community and for the photovoltaic industrial sector. 
But what perception does the user have of the presence of these installations in his or her surroundings? How can the industrial sector know whether its products are being accepted or not? Studies that take into account the users' opinion in order to be able to evaluate the perception and their visual impact in the city are lacking. Some more recent research that includes aspects related to image, perception of the city or the immediate surroundings, and take citizens into account (Guarachi Flores et al., 2016; Strazzera and Statzu, 2017), also fail to offer any data with which to evaluate people's opinion regarding the presence of these new technologies.

Collecting the opinions expressed by citizens and being able to consider them valuable research data would require having access to a varied sample of photovoltaic systems, installed in different types of buildings, so that they could be observed and evaluated by a significant sample of persons in an anonymous manner. Although this appears somewhat impractical, these characteristics can be found at a world-famous event that puts society in direct contact with the latest advances in photovoltaic technology for residential buildings. This event is the Solar Decathlon (SD), which was held for the first time in 2002 in the USA and has gone on to become, since the second edition in 2005, an important biannual contest for universities. The first European version of the competition (Solar Decathlon Europe, SDE) took place in Madrid in 2010 and was repeated in the same city in 2012 before moving to Versailles (Paris) for the 2014 exhibition. Each edition of this contest is an interesting showcase of the latest initiatives in the field of photovoltaics (Cronemberger et al., 2014).

This research is based on the projects presented at Solar Decathlon Europe 2014 (SDE 2014) (Fig. 3. 2), where 20 prototypes of solar-powered dwellings were submitted over a period of two weeks to 10 appraisals in order to evaluate aspects such as architecture, energy efficiency, sustainability, comfort conditions and innovation. In line with the European commitment to meet the 20/20/20 challenge, two main objectives were established for the SDE competitions: 1) to promote innovation and knowledge generation in order to improve the energy efficiency and sustainability of buildings and towns, as well as the integration of renewable energies, by transferring knowledge to the industrial domain, and 2) to make use of all types of media to raise society's awareness regarding the importance of using energy in a responsible way and of building together a more sustainable world (Vega and Rodriguez, 2014).

TheSDE is an event that is open to all, and the most common visitor profile is that of a young person with a university education who is well aware of the need to respect the environment. While the event is being held, the public can visit the inside of the prototypes and receive all kinds of information about them and about the way they work. 


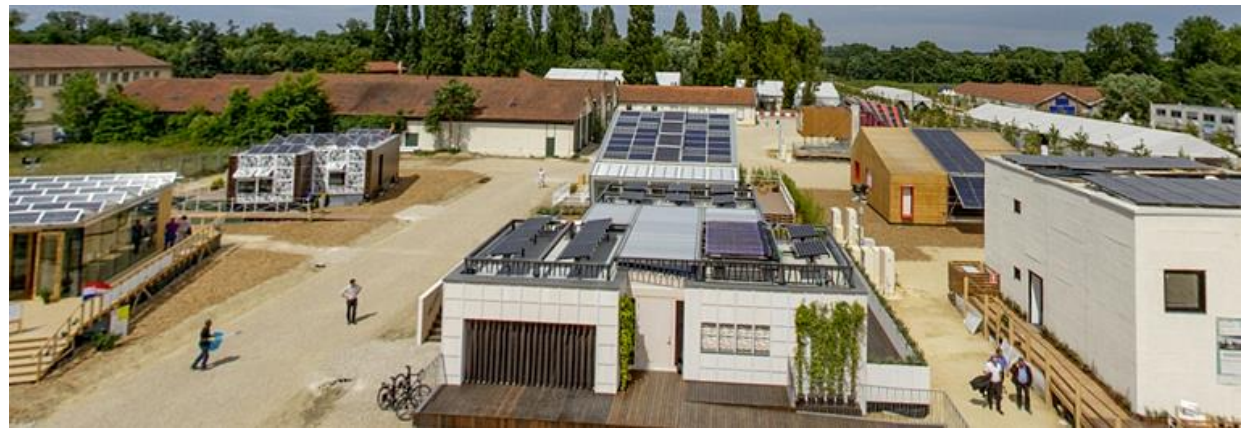

Fig. 3. 2 The Cité du Soleil, the venue where the Solar Decathlon Europe 2014 was held in Versailles, Paris. Image obtained from the official website: www.solardecathlon2014.fr/en

The aim of this study is to provide data that reflect what citizens feel when they see these "new installations", which would be part of the urban landscape seen on a dayto-day basis. This information is of great interest and will enable researchers to continue to work to improve future applications. The present study represents an important novelty as it collects data on the aesthetic perception of the use of photovoltaic technology in buildings, directly from the citizens through a survey. Another noteworthy novelty presented in this work is the analysis of aesthetic perception by comparing prototypes of self-sufficient solar homes, which offer us a wide range of ways to integrate photovoltaic energy in buildings. To this extent, the aesthetic perception was analysed for the two types of photovoltaic installations that can be found in buildings, namely, BIPV and BAPV. In addition, the prototypes have been categorized according to the appreciation of the installation from a street level point of view in order to know the influence on the final assessment. Overall, the results obtained show a new and interesting approach to the future development of sustainable building projects.

Since the use of these elements in the façade or the roofing of our buildings has a notable effect on their aesthetic, this study aims to identify society's acceptance or non-acceptance of this technology. There is widespread agreement on the fact that the application of photovoltaic technology changes the appearance of the urban landscape and this change may be positive or negative (Strazzera and Statzu, 2017). While some see it as an opportunity to modernise the city, others - especially in historic districts - are more critical about these aesthetic modifications.

Due to formal and design reasons, there are expected to be differences in the evaluation of the visual impressions caused by (fully integrated) BIPV and (superposed) BAPV technologies. This research therefore includes an analysis of the differences in the way the two types of technology are perceived by citizens. By so doing it will be possible to evaluate whether, in terms of the final aesthetic effect achieved, there is any justification for technicians to pay greater attention during the design phase to the use and development of BIPV rather than BAPV systems, given the higher rating for the aesthetic perception of the former. 


\subsection{Method}

\subsubsection{Validity of the data and limitations}

Data were collected by means of two surveys: (a) one with the prototypes that included BIPV technology in the envelope, and (b) one with the prototypes that used BAPV systems. Because the exhibition was open to the public for two weeks and more time was needed to obtain a significant sample, some of the surveys were carried out "on the spot" with the intention of later using photographs to compare and validate the results obtained after the event finished. The data analysis could therefore be performed using data from three experimental samples: (1) the surveys conducted in situ (BIPV-Versailles), used as a reference; (2) those carried out by means of pictures of integrated systems (BIPV-images); and (3) those carried out by means of pictures of superposed systems (BAPV-images).

Firstly, the data obtained with samples 1 and 2 were analysed to check for the existence of any similarities between them that made it possible to justify the ecological validity of the data obtained by evaluating images. Secondly, the acceptance of the prototypes was assessed by analysing the respondents' positive (pleasant) or negative (unpleasant) aesthetic perception and the degree of emotional activation (arousal). Finally, the results obtained for the prototypes with BIPV and BAPV technology were compared, and an analysis was also performed to determine the possible influence of sociodemographic variables on their aesthetic perception. The statistical software used to analyse the survey data was IBM SPSS Statistics v24.

Inevitably, the assessment of PV integration is, in a way, influenced by the architectural design. It must nevertheless be borne in mind that the housing design phase is a global process in which the aesthetic of the building affects the design of the PV system and vice versa. It would thus be incorrect to assess different kinds of PV systems for the same building. 20 solar housing prototypes with diverse types of PV installations were selected and used to compare the different outcomes offered by each of them and, in order to avoid the architectural influence when conducting the surveys, participants were informed about the specific location of the photovoltaic installation for each image.

The structure of the surveys was the same for the different samples that participated in the study, and consisted of a first part aimed at obtaining generic descriptive data and a second part that collected data referring to the respondents' feelings when they were shown pictures of the prototypes.

In order to reach a greater number of people, the surveys were conducted in pen and paper format but also via the Internet (using e-mail). In this regard, some studies (Roth, 2006) suggest that online surveys are appropriate and provide acceptable values regarding objectivity, reliability and the possibility of generalising the data. 


\subsubsection{Generic descriptive statistics}

Table 3. 1 Parameters used for the descriptive study of the samples.

\begin{tabular}{|c|c|c|c|c|c|c|}
\hline VALUE & AGE & GENDER & $\begin{array}{l}\text { LEVEL OF } \\
\text { EDUCATION }\end{array}$ & $\begin{array}{c}\text { CONNECTED } \\
\text { WITH } \\
\text { ARCHITECTURE }\end{array}$ & $\begin{array}{c}\text { ENVIRONMENTAL } \\
\text { CONCERN }\end{array}$ & HOUSING \\
\hline 1 & $\begin{array}{c}\text { between } \\
16 \text { and } 25\end{array}$ & man & None & No & None & Big city \\
\hline 2 & $\begin{array}{l}\text { between } \\
26 \text { and } 40\end{array}$ & woman & $\begin{array}{l}\text { Primary } \\
\text { School }\end{array}$ & Yes & Little & $\begin{array}{c}\text { Small } \\
\text { city/town }\end{array}$ \\
\hline 3 & $\begin{array}{l}\text { between } \\
41 \text { and } 55\end{array}$ & & $\begin{array}{c}\text { Secondary } \\
\text { school }\end{array}$ & & Quite high & $\begin{array}{l}\text { Semi-rural } \\
\& \text { rural area }\end{array}$ \\
\hline 4 & $\begin{array}{c}\text { between } \\
56 \text { and } 70\end{array}$ & & University & & High & \\
\hline 5 & $\begin{array}{l}\text { more than } \\
70 \\
\end{array}$ & & & & & \\
\hline
\end{tabular}

A profile of the sample was obtained using personal data such as age, gender, level of education, relationship between their qualifications and the field of architecture (to anticipate possible differences in the aesthetic perception of this group), their concern for the environment, and the type of setting they live in. Table 3. 1 summarises the values used in the study to define the levels of each of these variables.

\subsubsection{Prototypes}

A total of 22 prototypes were on show at the SDE 2014 exhibition: 20 of them were official participants in the contest and two were only on display. The surveys evaluated all the prototypes except two. "Casa Fénix" was excluded from the statistical analysis because some of the answers were missing from the surveys, which gave rise to an incorrect discrimination of the data with respect to the other prototypes. The prototype "Efden" was also excluded because its promoters failed to complete the construction of its envelope and it was therefore not considered suitable as a model for measuring the aesthetic perception of the system. Although they did not enter the SDE appraisals as competitors, both "éBRICKhouse" and "Membrain" were included as they were part of the exhibition of prototypes that the public were able to visit. Altogether the assessment took into account the 20 prototypes shown in Fig. 3. 3 and listed in the supplementary information, half of which employed BIPV technology, while the other half used BAPV.

\subsubsection{Evaluation of the aesthetic perception}

The subjective estimations of the emotions triggered by the prototypes (in the dimensions pleasant-unpleasant and emotional activation) were obtained using the Self-Assessment Manikin (SAM) (Bradley and Lang, 1994; Grimm and Kroschel, 2005). SAM is a non-verbal instrument that includes a pictorial scale for assessing emotional reactions when faced with different types of stimuli, which makes it easier to carry 

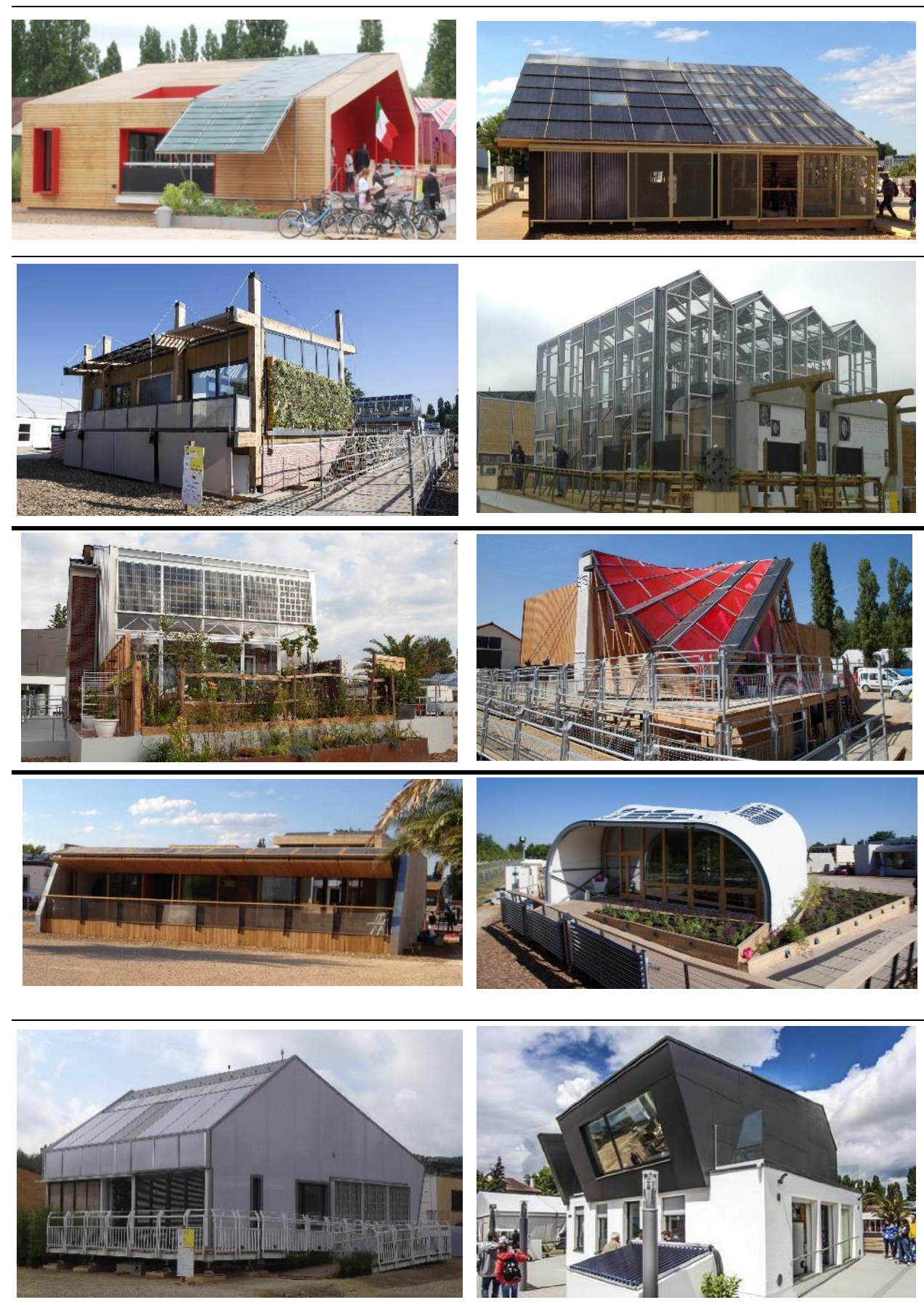

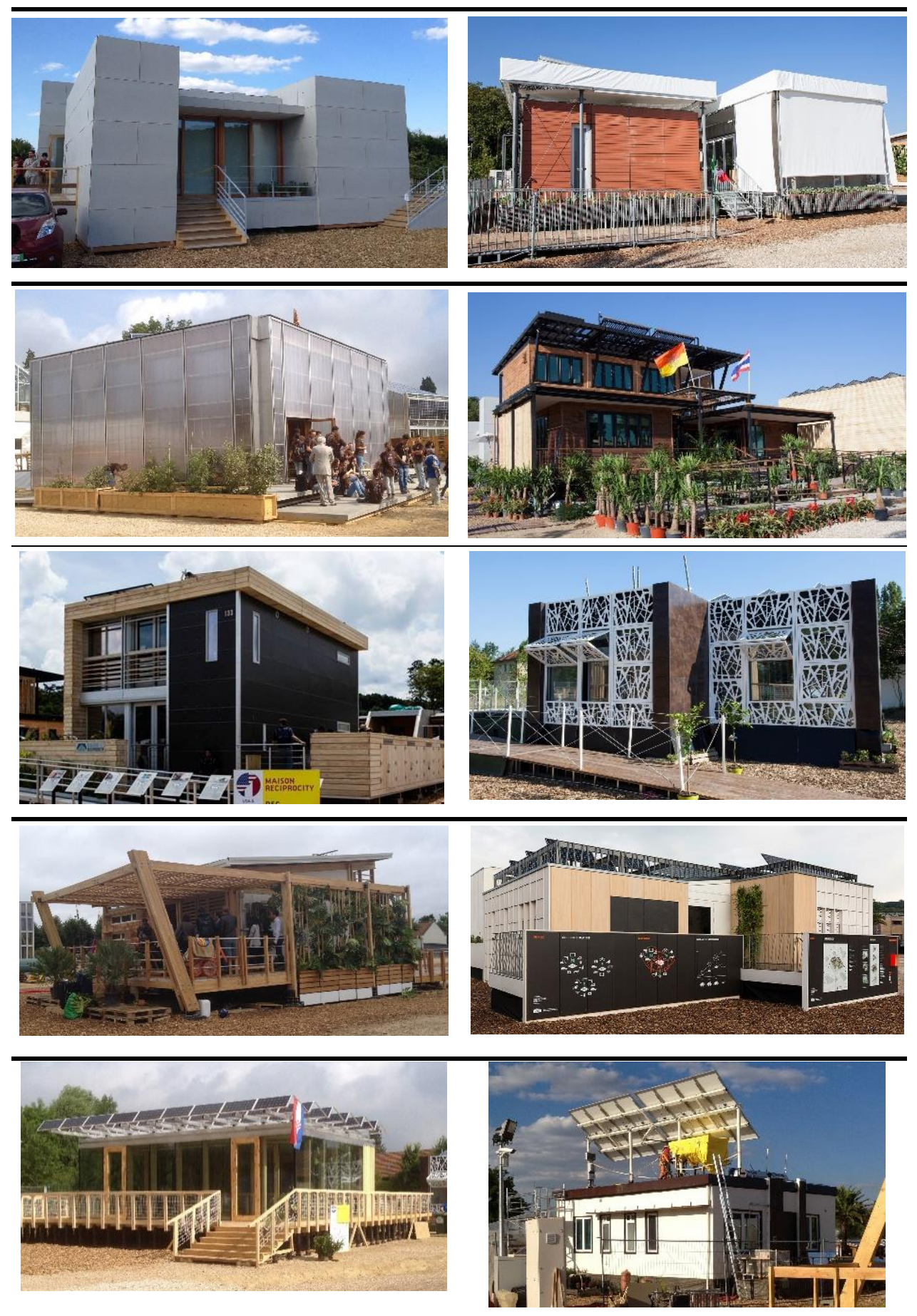

Fig. 3. 3 Prototypes from the SDE 2014 exhibition that were evaluated in the surveys, shown in rows in this order: Rhome for DenCity, Embrace, Symbcity House, Philéas, Prêt-à-Loger, Liv-lib', RoofTop, Techstyle House, Orchid House, OnTop, Renai, Casa System, Ressò, Adaptive, Reciprocity, éBRICKhouse, Trópika, Yourt, Membrain and HO 
out the survey in a multicultural setting such as the SDE, while at the same time avoiding possible mistakes due to misinterpretation resulting from changes of language. Only two dimensions were used for the affective assessment: hedonic valence (pleasant-unpleasant) and arousal (level of excitation). Dominance was not considered as a dimension because a pilot study showed it to be difficult to interpret. In fact, previous research suggests that hedonic valence and emotional arousal are the most important dimensions as regards connotative meaning and feelings (Bradley, Codispoti, Sabatinelli, \& Lang, 2001a; Mehrabian \& Russell, 1974). Similarly, we found another study that also used these two-dimensions to assess the aesthetic impact of buildings (Gifford et al., 2000).

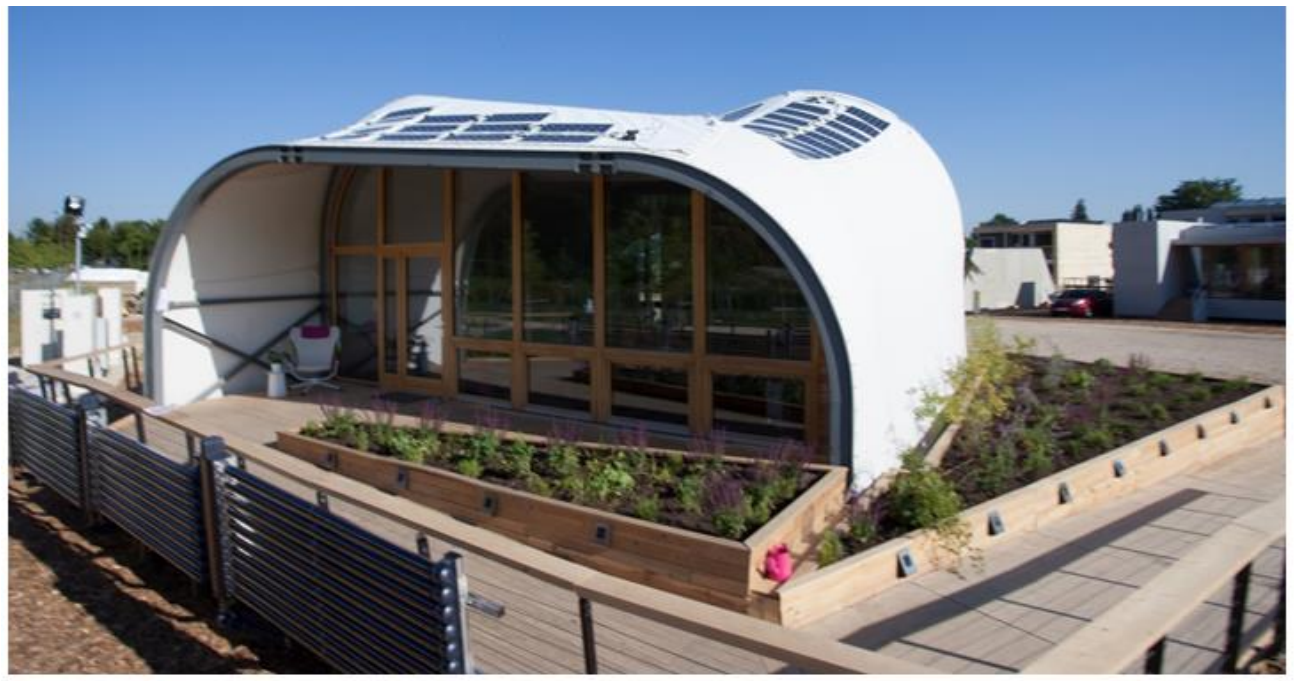

Tick the picture that best identifies your feelings:

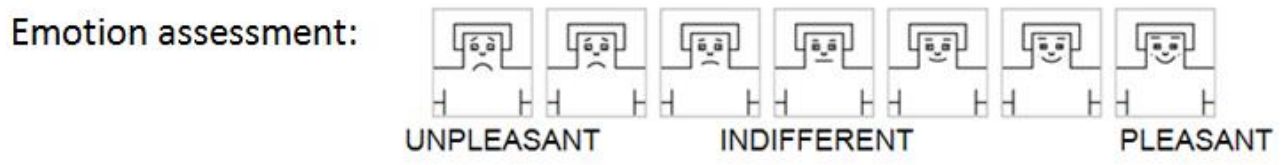

Excitation degree:

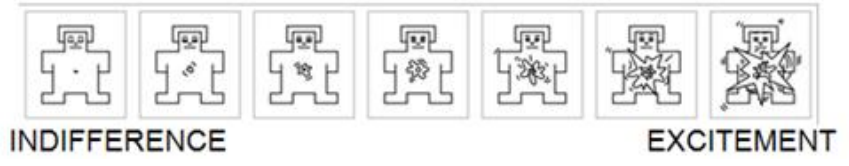

Fig. 3. 4 Example of the survey using the SAM method to score the parameters Valence and Arousal.

In our study, each dimension of the SAM was represented using a scale of 1-7 points, as shown in Fig. 3. 4. Participants were asked to mark the figure whose expression best matched their own feelings when they saw each prototype. 


\subsection{Results and discussion}

\subsubsection{Participants and characterisation of the sample}

The sizes of the three samples considered in this study are appropriate with a confidence level of $95 \%$ and a margin of error of $5 \%$. Sample 1, which was produced on onsite (BIPV-Versailles), consists of a total of 87 surveys in which 10 prototypes were evaluated, resulting in 870 ratings. Sample 2, which was produced by means of images of prototypes with integrated systems (BIPV-images), consists of a total of 253 surveys, resulting in 2529 ratings. And sample 3, which was produced by means of images of prototypes of superposed systems (BAPV-images), consists of 165 surveys that also evaluated 10 prototypes, resulting in 1650 ratings. The total number of ratings included in the study was 5049 . In all the surveys pictures were shown to identify the prototypes to be evaluated, but the respondents in Versailles were able to see the prototypes in situ, whereas the others could only see an image of each one.

The samples were characterised by performing a detailed analysis of the profile of the participants in each of them, taking into account the values used for the different parameters defined in Table 3. 1. In the surveys carried out with images, the samples are representative of all the age groups, but in the case of the surveys in Versailles the mean age was below 30, as the majority of visitors who attend the SDE are university students. The numbers of males and females in all the samples were quite balanced. Moreover, the number of participants with training related to architecture was low, around $10 \%$, and thus future studies could extend the sample to include more representatives of this group. Concern for the environment was rated as "3- Quite high" or "4- High" by almost all the respondents and, in the majority of cases, the place of residence was predominantly a small town for the surveys carried out in Spain, but also large cities for many of the respondents in Versailles.

Table 3. 2 shows the mean values (and the standard deviation) of the sociodemographic variables that were most representative of the profile of those who answered the survey, together with the number of people who took part in each sample, the total number of surveys being 505. In the case of the variable "relationship between the respondent's studies and the field of architecture", the value is given as the number and percentage of respondents with this relationship, since it is a dichotomous variable.

\subsubsection{Comparison BIPV-Versailles vs. BIPV-Spain}

A comparison of the data obtained in the presence of the prototypes and those obtained later by means of photographs shows the ecological (or statistical) validity of the results (Table 3. 3). This is of great interest for a case study like SDE 2014, a 


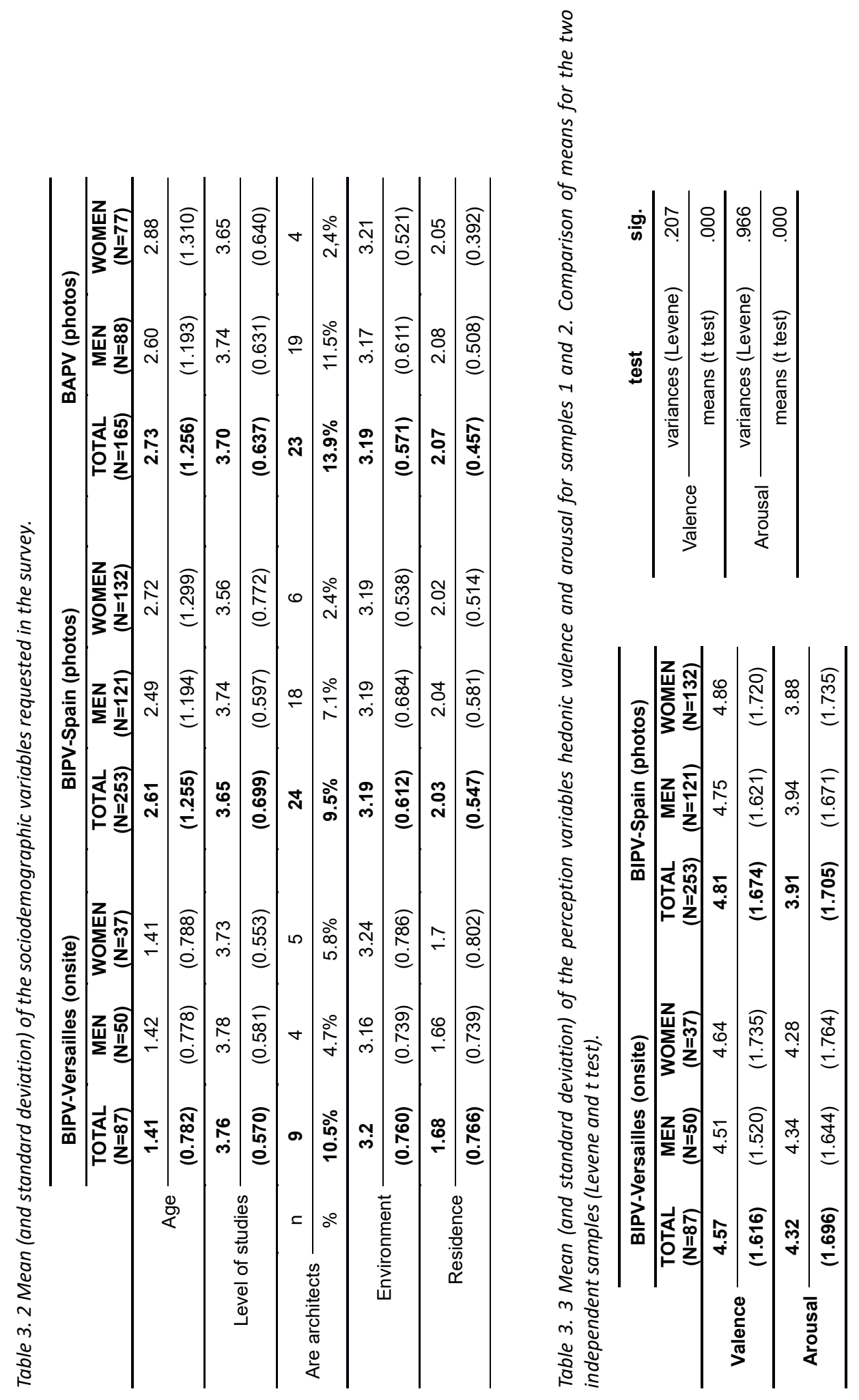


single one-off event where the exhibition has a limited duration of two weeks. It cannot be said that the perception is identical for the two samples, since the statistically significant result of the t test $(0.001$ level) concludes that there is no equality of means. The Levene test, however, assumes equality of variances for both hedonic valence and arousal.

Table 3. 3 shows that a slightly higher value is obtained for valence using photographs, but the respondent's activation or excitation is greater in the presence of the prototype. These results are to be expected if it is borne in mind that there are a number of factors that influence the process, such as the aesthetic quality of the photograph, which may be showing a better perspective of the prototype in optimal climatic conditions. In contrast, those who visited the SDE have seen all the façades of the building and the weather conditions were those prevailing in that moment. Exposure time is also different: whereas the photos are shown for approximately half a minute, visitors at the SDE spend several minutes looking at each building. Another factor which may be influencing the visitors' rating at the SDE is the fact that they know how the installations work and are used; this information is not available to the participants who rated the aesthetic perception by means of pictures.

Yet, despite the fact that the results of the test and these factors could cause certain imbalances in perception, the statistical validity of the data can be considered as acceptable because, within the scale from 1 to 7 that was used, similar values for perception are always found. It can therefore be said that the results obtained by means of photographs are valid for predicting whether the installation is seen as pleasant or not and whether the observer finds it stimulating or not.

As there was a notable difference of age between samples 1 and 2, the validity of these conclusions was tested by considering the same age bracket for both samples, and a similar result was obtained.

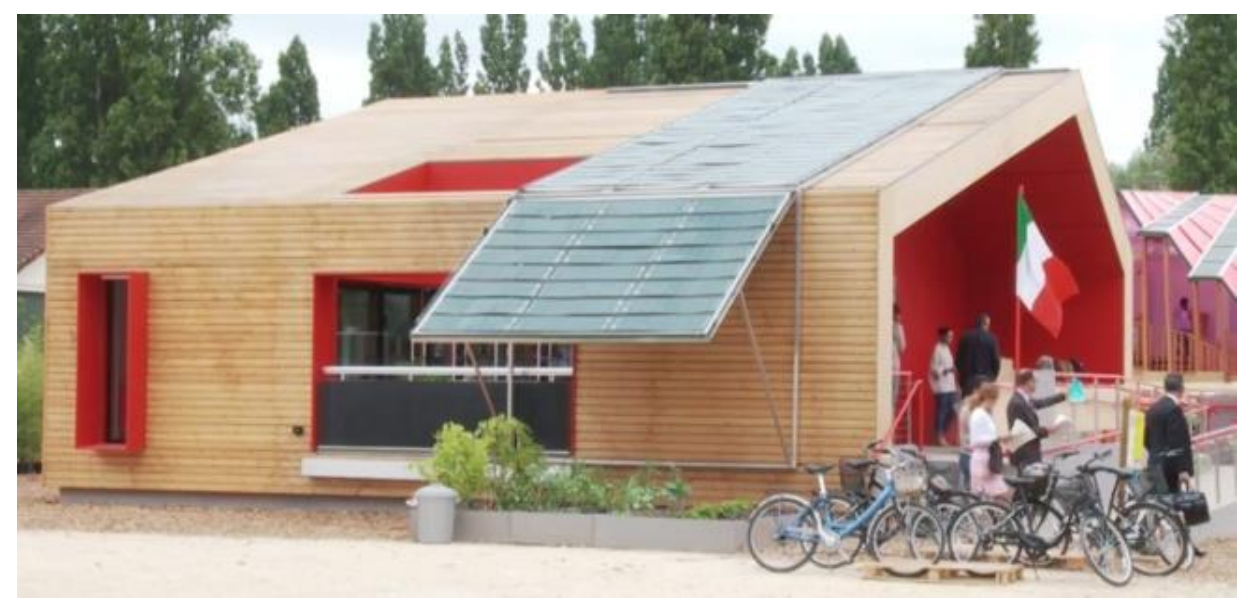

Fig. 3. 5 The prototype Rhome for DenCity from SDE 2014. 
Of the 10 prototypes with BIPV technology considered in the survey, it should be noted that the best rated, in terms of hedonic valence, in sample 1 (BIPV-Versailles) is also the prototype that obtained the best classification in the architecture appraisal, Rhome for DenCity (Fig. 3. 5). As can be seen in Fig. 3. 7, however, this prototype was rated second from last in sample 2 (BIPV-images).

As regards the degree of excitation, the prototype Rhome for DenCity had the second greatest impact, behind Techstyle House, in sample 1 (BIPV-Versailles). As in the case of hedonic valence, however, in Fig. 3. 8 it can be seen that it was rated last but one in terms of impact in sample 2 (BIPV-images), only slightly better than the prototype Orchid House.

In spite of the differences that may exist between the subjective ratings of the different prototypes, Orchid House stands out as a special case (Fig. 3. 6). This prototype was seen as less pleasant and as having less impact in both samples ( 1 and 2).
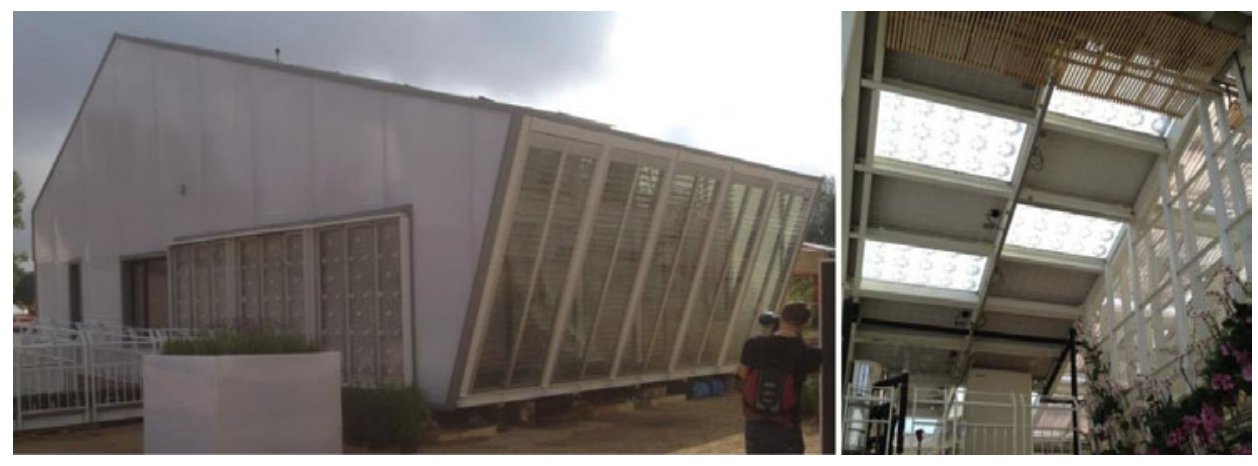

Fig. 3. 6 The prototype Orchid House from SDE 2014.

\subsubsection{Overall rating of hedonic valence and arousal}

After testing the statistical validity of the results obtained by means of photographs, samples 2 (BIPV-images) and 3 (BAPV-images) were considered for the analysis of the aesthetic perception of the prototypes. Evaluation data collected in situ were therefore discarded.

It is important to point out that in order to evaluate the aesthetic perception of the real observer, the images must have a similar angle or view compared to the perspective one might have at street level. Therefore, the appreciation of the installation is not the same, according to its degree of integration or visibility/hiddenness in the design. For this reason, even when results have been separately obtained for the BIPV and BAPV prototypes, at the same time they have been categorized into 3 groups according to the following criterion: 1) the PV installation is seen, perceived and understood; 2) part of the PV installation is seen, 
perceived; and 3) the PV installation is not seen. The 20 prototypes are shown in Fig. 3. 3. More information and the detailed classification is available in a supplementary document.

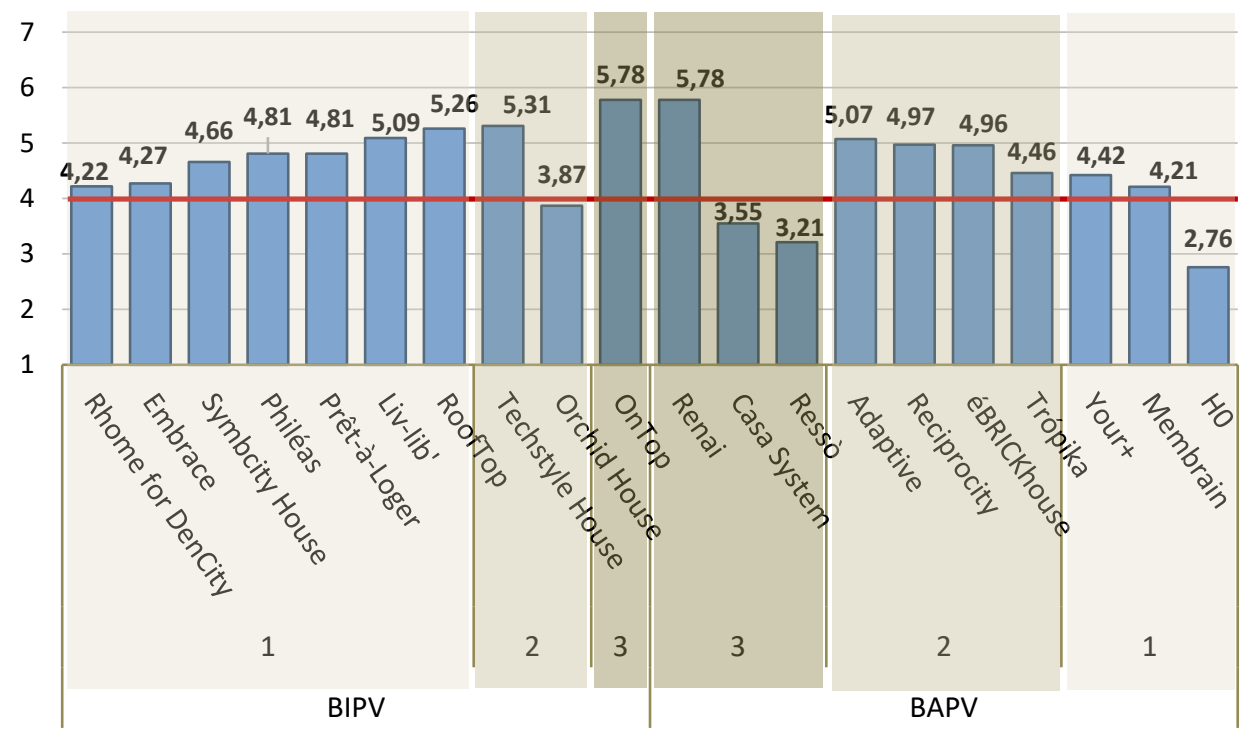

Fig. 3. 7 Mean values of hedonic valence for each prototype (rating with photographs).

As regards hedonic valence, the mean value of the scale (4) would represent the threshold indicating whether a prototype is liked $(>4)$ or not $(<4)$. Hence, on looking at Fig. 3. 7, with the BIPV prototypes on the left and the BAPV prototypes on the right, it can be said that in general terms the rating is positive, since only $20 \%$ of the prototypes were given a score below 4 .

In addition, with the exception of the cases of Orchid house, Casa System and Ressò, and regardless of whether it is BIPV or BAPV, we could observe a clear trend consisting in the fact that the more people see and perceive the photovoltaic installation, the less they score the hedonic valence. This is of great interest for the design of future installations, since the better the designer is able to integrate, conceal and disguise the installation, the greater the acceptance of the aesthetic result. If we look at the 3 cases that fall outside this standard, we can appreciate that the three prototypes interestingly belong to category 2 , all of them have simple geometric shapes and use plastic materials as coverings. These characteristics are certainly the cause of lower aesthetic acceptance.

With regard to arousal, the minimum value (1) represents the absence of activation during viewing the image (indifference). As can be seen in Fig. 3. 8, which also shows the BIPV prototypes on the left and the BAPV on the right, values between 3 and 5 
were obtained for all the cases, thereby reflecting a medium degree of excitation. There is no relationship between the 3 categories and the score obtained.

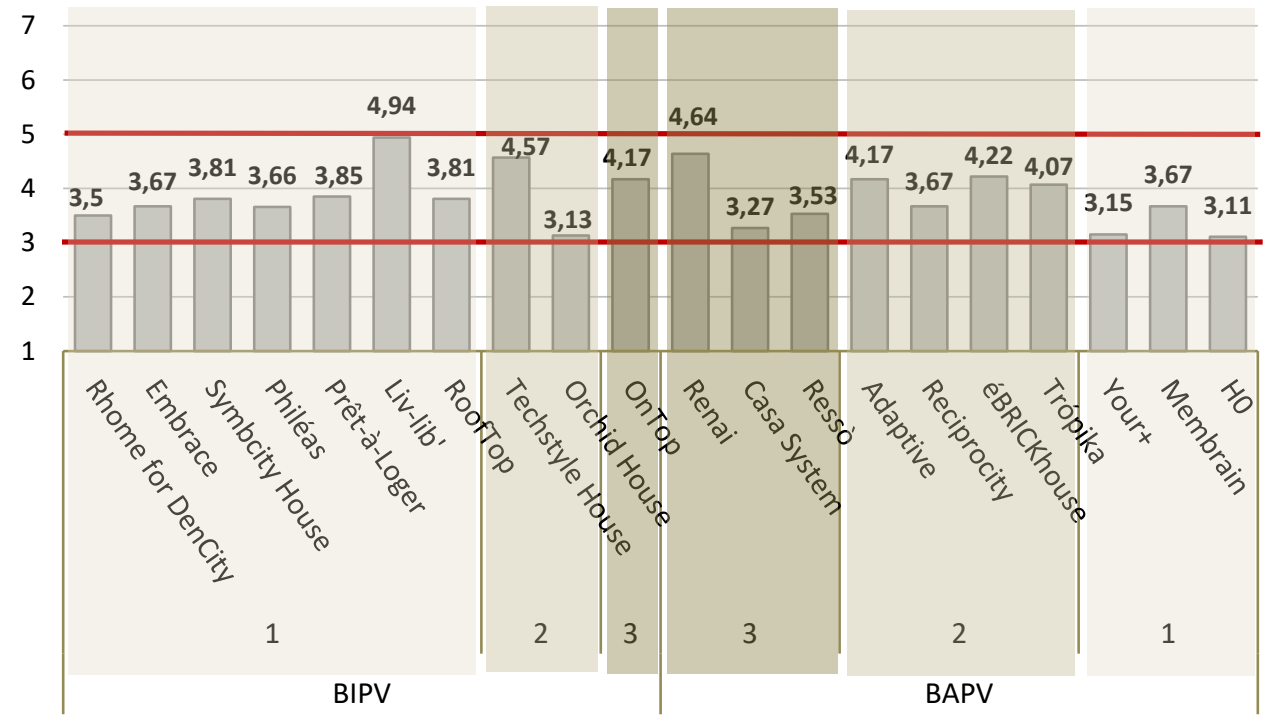

Fig. 3. 8 Mean values of arousal for each prototype (rating with photographs).

These results were to be expected and somehow agree with the findings from other research conducted on the affective evaluation of standardised images, such as the International Affective Picture System (IAPS) (Lang et al., 1997; Moltó et al., 2013), since pictures of houses - which can initially be considered "neutral"-involve a rather low level of activation, that is to say "calm". Furthermore, it can be observed how there is quite a lot of variation in the subjective ratings in the arousal dimension for the images that were found to be more pleasant $(>5)$, thereby also confirming that affective valence is independent of the level of arousal.

\subsubsection{Comparison BIPV vs. BAPV}

As shown in Fig. 3. 7, where the BIPV prototypes have clearly better scores than the BAPV installations, the total mean values for affective valence and arousal are higher for sample 2 than for sample 3. These data can be seen in Table 3. 4, where the rating of the prototypes is generally positive with a medium-low degree of excitation for both samples.

The results of the $t$ test summarised in Table 3.5 show that the equality of means between the two samples is not assumed for either of the two variables studied. That is to say, there are significant differences in the rating that offset the increased amount of work required to develop BIPV technology, as well as the initial economic investment needed to install it. If the integration of photovoltaic technology is not taken into consideration from the construction design phase, the result is an 
aesthetically less attractive building (Johnston, 2007). Even though BIPV technology is generally perceived as being expensive or even as having a prohibitive price (Yang and Zou, 2016), this does not appear to have a negative influence on aesthetic perception. The respondent presumably also perceives that an economic investment has to be made in the case of BAPV technology, and therefore economic cost is not an especially significant factor in this study.

Table 3. 4 Mean (and standard deviation) of the affective evaluations of hedonic valence and arousal for samples 2 and 3.

\begin{tabular}{ccccccc}
\cline { 2 - 7 } & \multicolumn{3}{c}{ BIPV-Spain (photos) } & \multicolumn{3}{c}{ BAPV (photos) } \\
\cline { 2 - 7 } & $\begin{array}{c}\text { TOTAL } \\
(\mathbf{N}=\mathbf{2 5 3})\end{array}$ & $\begin{array}{c}\text { MEN } \\
(\mathbf{N}=\mathbf{1 2 1})\end{array}$ & $\begin{array}{c}\text { WOMEN } \\
(\mathbf{N}=\mathbf{1 3 2})\end{array}$ & $\begin{array}{c}\text { TOTAL } \\
(\mathbf{N}=\mathbf{1 6 5})\end{array}$ & $\begin{array}{c}\text { MEN } \\
(\mathbf{N}=\mathbf{8 8})\end{array}$ & $\begin{array}{c}\text { WOMEN } \\
(\mathbf{N}=\mathbf{7 7})\end{array}$ \\
\hline \multirow{2}{*}{ Valence } & $\mathbf{4 . 8 1}$ & 4.75 & 4.86 & $\mathbf{4 . 3 4}$ & 4.40 & 4.26 \\
\cline { 2 - 7 } & $\mathbf{( 1 . 6 7 4 )}$ & $(1.621)$ & $(1.720)$ & $\mathbf{( 1 . 7 3 0 )}$ & $(1.598)$ & $(1.868)$ \\
\hline \multirow{2}{*}{ Arousal } & $\mathbf{3 . 9 1}$ & 3.94 & 3.88 & $\mathbf{3 . 7 5}$ & 3.75 & 3.75 \\
\cline { 2 - 7 } & $\mathbf{( 1 . 7 0 5 )}$ & $(1.671)$ & $(1.735)$ & $\mathbf{( 1 . 7 4 8 )}$ & $(1.663)$ & $(1.841)$ \\
\hline
\end{tabular}

However, it should be remembered that the rating is quite similar for the two technologies and this difference could therefore be reduced if the respondent perceives the technological development and economic investment required for the installation of the BIPV system to be very high. There are factors that limit the applicability of these systems in different countries, such as energy and economic policies or the geographical and climatologic conditions (Radmehr et al., 2014).

Table 3. 5 Results of the Levene and Student's $t$ tests for the independent samples BIPV and BAPV.

Independent samples test

\begin{tabular}{|c|c|c|c|c|c|c|c|c|c|c|}
\hline & & $\begin{array}{l}\text { Lever } \\
\text { and e } \\
\text { of var }\end{array}$ & $\begin{array}{l}\text { test } \\
\text { dality } \\
\text { nces }\end{array}$ & \multicolumn{7}{|c|}{$t$ test for equality of means } \\
\hline & & \multirow[b]{2}{*}{$\mathrm{F}$} & \multirow[b]{2}{*}{ Sig. } & \multirow[b]{2}{*}{$\mathrm{t}$} & \multirow[b]{2}{*}{ df } & \multirow{2}{*}{$\begin{array}{l}\text { Sig. } \\
\text { (bilat- } \\
\text { eral) }\end{array}$} & \multirow{2}{*}{$\begin{array}{l}\text { Means } \\
\text { differ- } \\
\text { ence }\end{array}$} & \multirow{2}{*}{$\begin{array}{c}\text { Std } \\
\text { error } \\
\text { differe } \\
\text { nce }\end{array}$} & \multicolumn{2}{|c|}{$\begin{array}{c}95 \% \text { conf. } \\
\text { interval of the } \\
\text { difference }\end{array}$} \\
\hline & & & & & & & & & Inf. & Sup. \\
\hline \multirow[t]{2}{*}{$\begin{array}{l}\text { Pleasant/ } \\
\text { unpleasant } \\
\text { (valence) }\end{array}$} & $\begin{array}{l}\text { Equal } \\
\text { variances } \\
\text { are } \\
\text { assumed }\end{array}$ & 3.057 & .080 & -8.741 & 4177 & .000 & -.469 & .054 & -.574 & -.364 \\
\hline & $\begin{array}{l}\text { Equal } \\
\text { variances } \\
\text { are not } \\
\text { assumed }\end{array}$ & & & -8.680 & 3441.043 & .000 & -.469 & .054 & -.575 & -.363 \\
\hline \multirow[t]{2}{*}{$\begin{array}{l}\text { Excitation } \\
\text { degree } \\
\text { (arousal) }\end{array}$} & $\begin{array}{l}\text { Equal } \\
\text { variances } \\
\text { are } \\
\text { assumed }\end{array}$ & 4.324 & .038 & -2.958 & 4177 & .003 & -.161 & .054 & -.268 & -.054 \\
\hline & $\begin{array}{l}\text { Equal } \\
\text { variances } \\
\text { are not } \\
\text { assumed }\end{array}$ & & & -2.942 & 3461.735 & .003 & -.161 & .055 & -.269 & -.054 \\
\hline
\end{tabular}


If we take into account the visibility of the installation and therefore the categorisation we have made in section 3.3, there is certain uncertainty in the BAPV prototypes of group 3 (Renai, Casa System and Ressò) since those cases could be confounded with a BIPV installation because it is not seen from any view. However, the calculation of $t$ Tests comparison by excluding these 3 prototypes has shown very similar results compared to those obtained with all the prototypes.

As regards the influence of the sociodemographic parameters on aesthetic perception, Table 3. 6 shows the tests that were conducted and the results obtained in each of them. The only parameter found to have a clear influence on both variables is age. For both BIPV and BAPV technology, the younger the respondent is, the higher the degree of activation he or she experiences. Also in the case of hedonic valence, in the prototypes with BAPV technology the younger the respondent is, the higher the values are. This indicates that, generally speaking, older people are less impressed and are less willing to accept the industrial aesthetics offered by BAPV solutions. These results are in line with those of several studies that also use the SAM to evaluate affective images from the International Affective Picture System (IAPS). In those studies, the results show a greater intensity of affect on the part of the younger group, but also greater emotional control and higher levels of positive affect for the older group (Backs et al., 2005). Moreover, in the case of the pleasant images, the older group experiences a lower degree of excitation than the members of the younger group (Grühn and Scheibe, 2008).

The degree of concern for the environment was found to be high for most of the respondents. The results on the use of BIPV technology indicate that people with greater environmental awareness rated the prototypes with higher scores on both affective valence and activation.

Although some differences are observed in Table 3. 3 and Table 3. 4, the results of the statistical analyses suggest that gender does not have any substantial influence on the participants' aesthetic perception. These findings coincide with those of another study (Bradley, Codispoti, Sabatinelli, \& Lang, 2001b), in which it was found that women tend to give more extreme scores on the hedonic valence dimension (especially in the case of unpleasant images), whereas the affective reactions to normal life events (whether pleasant or unpleasant) are quite similar for men and women.

Finally, the respondents' relationship with architecture and their place of residence showed a certain influence on the evaluation of aesthetic perception, but the sample is not sufficiently representative to be able to consider these results as conclusive. However, regarding the architects, results agree with the conclusions of other research which concludes that the assessment by architects and non-architects is different (Gifford et al., 2000). 
Table 3. 6 Tests conducted to analyse the influence of the sociodemographic parameters on perception.

\begin{tabular}{|c|c|c|c|c|c|}
\hline Variable & Test & & Sig. & Results & Conclusion \\
\hline \multirow{4}{*}{ Gender } & & \multirow{2}{*}{ Valence } & .016 & NO eq. of variances & \multirow{4}{*}{$\begin{array}{l}\text { The variable Gender does not influence } \\
\text { perception. }\end{array}$} \\
\hline & & & .119 & YES eq. of means & \\
\hline & & \multirow{2}{*}{ Arousal } & .029 & NO eq. of variances & \\
\hline & & & .367 & YES eq. of means & \\
\hline \multirow{2}{*}{ Age } & \multirow{2}{*}{ ANOVA } & Valence & .140 & YES eq. of means & \multirow{2}{*}{$\begin{array}{l}\text { The variable AGE DOES INFLUENCE THE } \\
\text { LEVEL OF AROUSAL, but not the valence. } \\
\text { Older people are less impressed. }\end{array}$} \\
\hline & & Arousal & .000 & NO eq. of means & \\
\hline \multirow{2}{*}{$\begin{array}{l}\text { Level of } \\
\text { education }\end{array}$} & \multirow{2}{*}{ ANOVA } & Valence & .144 & YES eq. of means & \multirow{2}{*}{$\begin{array}{l}\text { The variable Level of education does not } \\
\text { influence perception. }\end{array}$} \\
\hline & & Arousal & .124 & YES eq. of means & \\
\hline \multirow{4}{*}{ Architects? } & \multirow{4}{*}{$\mathrm{t}$} & \multirow{2}{*}{ Valence } & .001 & NO eq. of variances & \multirow{4}{*}{$\begin{array}{l}\text { Whether or not the respondents have } \\
\text { some relationship with architecture DOES } \\
\text { INFLUENCE AESTHETIC PERCEPTION. In } \\
\text { both variables, those who have some } \\
\text { relationship with architecture score higher. }\end{array}$} \\
\hline & & & .000 & NO eq. of means & \\
\hline & & \multirow{2}{*}{ Arousal } & .683 & YES eq. of variances & \\
\hline & & & .007 & NO eq. of means & \\
\hline \multirow{2}{*}{$\begin{array}{l}\text { Concern for } \\
\text { the } \\
\text { environment }\end{array}$} & \multirow{2}{*}{ ANOVA } & Valence & .000 & NO eq. of means & \multirow{2}{*}{$\begin{array}{l}\text { The degree of concern for the environment } \\
\text { DOES INFLUENCE AESTHETIC PERCEPTION } \\
\text { for both variables. }\end{array}$} \\
\hline & & Arousal & .002 & NO eq. of means & \\
\hline \multirow{2}{*}{$\begin{array}{l}\text { Place of } \\
\text { residence }\end{array}$} & \multirow{2}{*}{ ANOVA } & Valence & .873 & YES eq. of means & \multirow{2}{*}{$\begin{array}{l}\text { The place of residence does not influence } \\
\text { perception. }\end{array}$} \\
\hline & & Arousal & .192 & YES eq. of means & \\
\hline
\end{tabular}

BAPV:

\begin{tabular}{|c|c|c|c|c|c|}
\hline Variable & Test & & & Results & Conclusion \\
\hline \multirow{4}{*}{ Gender } & \multirow{4}{*}{$t$} & \multirow{2}{*}{ Valence } & .000 & NO eq. of variances & \multirow{4}{*}{$\begin{array}{l}\text { The variable Gender does not influence } \\
\text { perception. }\end{array}$} \\
\hline & & & .106 & YES eq. of means & \\
\hline & & \multirow{2}{*}{ Arousal } & .000 & NO eq. of variances & \\
\hline & & & .973 & YES eq. of means & \\
\hline \multirow[b]{2}{*}{ Age } & \multirow[b]{2}{*}{ ANOVA } & Valence & .000 & NO eq. of means & \multirow{2}{*}{$\begin{array}{l}\text { AGE DOES INFLUENCE AESTHETIC } \\
\text { PERCEPTION. Both in valence and in } \\
\text { arousal, the younger the respondents are, } \\
\text { the higher they score the two variables. }\end{array}$} \\
\hline & & Arousal & .000 & NO eq. of means & \\
\hline \multirow[b]{2}{*}{$\begin{array}{l}\text { Level of } \\
\text { education }\end{array}$} & \multirow[b]{2}{*}{ ANOVA } & Valence & .000 & NO eq. of means & \multirow{2}{*}{$\begin{array}{l}\text { This variable appears to influence aesthetic } \\
\text { perception, but this result is a consequence } \\
\text { of the fact that practically all those with a } \\
\text { secondary education belong to the group } \\
\text { of those aged over } 56 \text {, who, as we have } \\
\text { already seen, give lower scores. }\end{array}$} \\
\hline & & Arousal & .000 & NO eq. of means & \\
\hline \multirow{4}{*}{ Architects? } & \multirow{4}{*}{$\mathrm{t}$} & \multirow{2}{*}{ Valence } & .000 & NO eq. of variances & \multirow{4}{*}{$\begin{array}{l}\text { Whether or not respondents have some } \\
\text { relationship with architecture DOES } \\
\text { INFLUENCE THE LEVEL OF EMOTIONAL } \\
\text { AROUSAL, but not hedonic valence. } \\
\text { Architects give higher scores in activation. }\end{array}$} \\
\hline & & & .136 & YES eq. of means & \\
\hline & & \multirow{2}{*}{ Arousal } & .000 & NO eq. of variances & \\
\hline & & & .047 & NO eq. of means & \\
\hline \multirow{2}{*}{$\begin{array}{l}\text { Concern for } \\
\text { the } \\
\text { environment }\end{array}$} & \multirow{2}{*}{ ANOVA } & Valence & .205 & YES eq. of means & \multirow{2}{*}{$\begin{array}{l}\text { The degree of concern for the environment } \\
\text { does not influence aesthetic perception. }\end{array}$} \\
\hline & & Arousal & .603 & YES eq. of means & \\
\hline \multirow{2}{*}{$\begin{array}{l}\text { Place of } \\
\text { residence }\end{array}$} & \multirow[b]{2}{*}{ ANOVA } & Valence & .007 & NO eq. of means & \multirow{2}{*}{$\begin{array}{l}\text { There is a certain relationship between the } \\
\text { highest scores and participants who live in } \\
\text { big cities, but the participation by members } \\
\text { of this group is very low. }\end{array}$} \\
\hline & & Arousal & .000 & NO eq. of means & \\
\hline
\end{tabular}




\subsection{Conclusions}

Despite the differences in aesthetic between the two systems, the prototypes were generally given a positive rating, with scores above 4 for $80 \%$ of all the prototypes evaluated. It can therefore be deduced that the presence of these new technologies in the envelope of buildings is well accepted by users. The level of activation (arousal or emotional intensity) triggered by the prototypes was not especially notable, as the mean values always ranged between 3 and 5 on a scale of 1 (indifference) to 7 (excitement).

Nevertheless, from a comparison of the results obtained for the two types of photovoltaic systems it can be concluded that there are relevant differences in how they are perceived (error range of 5\%). BIPV technology, which requires greater attention in the design and a higher initial economic investment, also enjoys greater aesthetic acceptance by respondents with higher values for both hedonic valence and level of emotional intensity. The range of scores, however, was not very wide and this is the reason why the differences between the two systems were not very pronounced. As a result, an excessively high cost or an important technological difficulty could be significant factors that, in some cases, lead to a BAPV system being chosen rather than a BIPV installation.

One factor that has proved to be of great relevance is the degree of appreciation of the system, since there seems to be a clear trend showing that the more you see and perceive the photovoltaic installation the less you score the hedonic valence. This result is very interesting and should be taken into account by engineers, architects and the PV sector for the development of future sustainable cities design.

Lastly, the analysis of the sociodemographic factors that could affect aesthetic perception showed that age is a factor that clearly influences the rating. The younger group generally gave higher scores on emotional intensity. With regard to hedonic valence, the younger the age of the respondent is, the better the acceptance of BAPV technology is, which is the one that gives the prototypes a more "industrial" appearance. Consequently, it can be understood that older people are the ones who penalise to a greater extent the lack of a careful integration of the system within the building envelope.

\section{REFERENCES}

Athienitis, A.K., Candanedo, J.A., 2010. Building integration of photovoltaic systems in cold climates, in: Photonics North 2010. https://doi.org/10/bhxv9x

Azzouz, A., Borchers, M., Moreira, J., Mavrogianni, A., 2017. Life cycle assessment of energy conservation measures during early stage office building design: A case study in London, UK. Energy Build. 139, 547-568. https://doi.org/10/f9zsqz 
Backs, R.W., da Silva, S.P., Han, K., 2005. A comparison of younger and older adults' selfassessment manikin ratings of affective pictures. Exp. Aging Res. 31, 421-440. https://doi.org/10/fhx4nx

Bastos, J., Batterman, S.A., Freire, F., 2014. Life-cycle energy and greenhouse gas analysis of three building types in a residential area in Lisbon. Energy Build. 69, 344-353. https://doi.org/10/f5sdf7

Bonomo, P., Frontini, F., De Berardinis, P., Donsante, I., 2017. BIPV: building envelope solutions in a multi-criteria approach. A method for assessing life-cycle costs in the early design phase. Adv. Build. Energy Res. 11, 104-129. https://doi.org/10/drwz

Bradley, M.M., Codispoti, M., Cuthbert, B.N., Lang, P.J., 2001a. Emotion and motivation I: defensive and appetitive reactions in picture processing. Emotion 1, 300-319. https://doi.org/10/d7tq64

Bradley, M.M., Codispoti, M., Sabatinelli, D., Lang, P.J., 2001b. Emotion and motivation II: sex differences in picture processing. Emotion 1, 300-319. https://doi.org/10/fpdcf2

Bradley, M.M., Lang, P.J., 1994. Measuring emotion: The self-assessment manikin and the semantic differential. J. Behav. Ther. Exp. Psychiatry 25, 49-59. https://doi.org/10/bx59sf

Buyle, M., Braet, J., Audenaert, A., 2013. Life cycle assessment in the construction sector: A review. Renew. Sustain. Energy Rev. 26, 379-388. https://doi.org/10/f5fvnq

Cabeza, L.F., Rincón, L., Vilariño, V., Pérez, G., Castell, A., 2014. Life cycle assessment (LCA) and life cycle energy analysis (LCEA) of buildings and the building sector: A review. Renew. Sustain. Energy Rev. 29, 394-416. https://doi.org/10/dr9z

Cerón, I., Caamaño-Martín, E., Neila, F.J., 2013. 'State-of-the-art' of building integrated photovoltaic products. Renew. Energy 58, 127-133. https://doi.org/10/drw3

Cronemberger, J., Corpas, M.A., Cerón, I., Caamaño-Martín, E., Sánchez, S.V., 2014. BIPV technology application: Highlighting advances, tendencies and solutions through Solar Decathlon Europe houses. Energy Build. 83, 44-56. https://doi.org/10/drw5

D’Orazio, M., Di Perna, C., Di Giuseppe, E., 2013. Performance assessment of different roof integrated photovoltaic modules under Mediterranean Climate. Energy Procedia 42, 183-192. https://doi.org/10/drw6

Fleiß, E., Hatzl, S., Seebauer, S., Posch, A., 2017. Money, not morale: The impact of desires and beliefs on private investment in photovoltaic citizen participation initiatives. J. Clean. Prod. 141, 920-927. https://doi.org/10/f9fbjz

Ghattas, R., Gregory, J., Olivetti, E., Greene, S., 2013. Life Cycle Assessment for Residential Buildings : A Literature Review and Gap Analysis 1-21.

Gifford, R., Hine, D.W., Muller-Clemm, W., D’Arcy J Reynolds, J., Shaw, K.T., 2000. Decoding modern architecture. A lens model approach for understanding the aesthetic 
differences of architects and laypersons. Environ. Behav. 32, 163-187.

Gobierno de España, 2013. Documento básico HE ahorro de energía. Código técnico la Edif. Doc. básico HE Ahorr. energía 2013, 1-70.

Grimm, M., Kroschel, K., 2005. Evaluation of natural emotions using self assessment manikins, in: IEEE Workshop on Automatic Speech Recognitionand Understanding. IEEE, San Juan, Puerto Rico, pp. 381-385. https://doi.org/10/ff4qbf

Grühn, D., Scheibe, S., 2008. Age-related differences in valence and arousal ratings of pictures from the International Affective Picture System (IAPS): Do ratings become more extreme with age? Behav. Res. Methods 40, 512-521. https://doi.org/10/d54b5k

Guarachi Flores, J., García, R., Jofré, J., 2016. Integración arquitectónica de la fachada fotovoltaica. Potencial solar y percepción de usuario en la vivienda colectiva. Arquit. y Urban. XXXVII, 33-48.

Hemmerle, C., Hemmerle, C., 2016. Solar PV building skins: Structural requirements and environmental benefits. J. Facade Des. Eng. 5, 93-105. https://doi.org/10/drw9

Henemann, A., 2008. BIPV: Built-in solar energy. Renew. Energy Focus 9, 14,16-19. https://doi.org/10.1016/S1471-0846(08)70179-3

Johnston, D., 2007. Solar energy systems installed on Chinese-style buildings. Energy Build. 39, 385-392. https://doi.org/10/fg5t7c

Lang, P., Bradley, M., Cuthbert, B., 1997. International Affective Picture System (IAPS): Technical manual and affective ratings. NIMH Cent. Study Emot. Atten. 39-58.

Lim, C.H., Sopian, K., Sulaiman, Y., Ruslan, M.H., Yahya, M., 2009. Assessment of public perception on photovoltaic application in Malaysia urban residential areas using Trudgill's framework for analysis. Eur. J. Soc. Sci. 8, 589-603.

Loulas, N.M., Karteris, M.M., Pilavachi, P.A., Papadopoulos, A.M., 2012. Photovoltaics in urban environment: A case study for typical apartment buildings in Greece. Renew. Energy 48, 453-463. https://doi.org/10/drxc

Makrides, G., Zinsser, B., Norton, M., Georghiou, G.E., Schubert, M., Werner, J.H., 2010. Potential of photovoltaic systems in countries with high solar irradiation. Renew. Sustain. Energy Rev. 14, 754-762. https://doi.org/10/b8r4pt

Makrides, G., Zinsser, B., Phinikarides, A., Schubert, M., Georghiou, G.E., 2012. Temperature and thermal annealing effects on different photovoltaic technologies. Renew. Energy 43, 407-417. https://doi.org/10/fzs84s

Makrides, G., Zinsser, B., Schubert, M., Georghiou, G.E., 2013. Seasonal performance comparison of different photovoltaic technologies installed in Cyprus and Germany. Int. J. Sustain. Energy 32, 466-488. https://doi.org/10/drxd

Mehrabian, A., Russell, J.A., 1974. An approach to environmental psychology, Cambridge 
Mass The MIT Press.

Michael, A., Bougiatioti, F., Oikonomou, A., 2010. Less could be more: architectural integration of active solar systems in existing urban centres, in: 7th Mediterranean Conference and Exhibition on Power Generation, Transmission, Distribution and Energy Conversion (MedPower 2010). IET, pp. 189-189. https://doi.org/10/ftr565

Moltó, J., Segarra, P., López, R., Esteller, À., Fonfría, A., Pastor, M.C., Poy, R., 2013. Adaptación española del "International Affective Picture System" (IAPS). Tercera parte. An. Psicol. 29, 965-984. https://doi.org/10/dr9t

Ortiz, O., Bonnet, C., Bruno, J.C., Castells, F., 2009. Sustainability based on LCM of residential dwellings: A case study in Catalonia, Spain. Build. Environ. 44, 584-594. https://doi.org/10/bqczvj

Petter, B., Breivik, C., Drolsum, H., 2012. Building integrated photovoltaic products: A stateof-the-art review and future research opportunities. Sol. Energy Mater. Sol. Cells 100, 69-96. https://doi.org/10/drxr

Peuportier, B.L.., 2001. Life cycle assessment applied to the comparative evaluation of single family houses in the French context. Energy Build. 33, 443-450. https://doi.org/10/bx6tjv

Portolan dos Santos, Í., Rüther, R., 2012. The potential of building-integrated (BIPV) and building-applied photovoltaics (BAPV) in single-family, urban residences at low latitudes in Brazil. Energy Build. 50, 290-297. https://doi.org/10/drxt

Radmehr, M., Willis, K., Kenechi, U.E., 2014. A framework for evaluating WTP for BIPV in residential housing design in developing countries: A case study of North Cyprus. Energy Policy 70, 207-216. https://doi.org/10/drxv

Ramesh, T., Prakash, R., Shukla, K.K., 2010. Life cycle energy analysis of buildings: An overview. Energy Build. 42, 1592-1600.

Roth, M., 2006. Validating the use of Internet survey techniques in visual landscape assessment-An empirical study from Germany. Landsc. Urban Plan. 78, 179-192. https://doi.org/10/cx44pk

Sagani, A., Mihelis, J., Dedoussis, V., 2017. Techno-economic analysis and life-cycle environmental impacts of small-scale building-integrated PV systems in Greece. Energy Build. 139, 277-290. https://doi.org/10/f9ztx4

Strazzera, E., Statzu, V., 2017. Fostering photovoltaic technologies in Mediterranean cities: Consumers' demand and social acceptance. Renew. Energy 102, 361-371. https://doi.org/10/f9hmhh

Torres-Sibille, A.C., Cloquell-Ballester, Vicente-A., Cloquell-Ballester, Víctor-A., Artacho, M.A., 2009. Aesthetic impact assessment of solar power plants: An objective and a subjective approach. Renew. Sustain. Energy Rev. 13, 986-999. https://doi.org/10/c4xh7r 
Vega, S., Rodriguez, E., 2014. Science behind and beyond the Solar Decathlon Europe 2012 competition. Energy Build. 83, 1-2. https://doi.org/10/drwq

Vivar, M., Fuentes, M., Norton, M., Makrides, G., De Bustamante, I., 2014. Estimation of sunshine duration from the global irradiance measured by a photovoltaic silicon solar cell. Renew. Sustain. Energy Rev. 36, 26-33. https://doi.org/10/f593d2

Werner, F., Richter, K., 2007. Wooden building products in comparative LCA. Int. J. Life Cycle Assess. 12, 470-479. https://doi.org/10/bbg82j

Yang, R.J., Zou, P.X.W., 2016. Building integrated photovoltaics (BIPV): costs, benefits, risks, barriers and improvement strategy. Int. J. Constr. Manag. 16, 39-53. https://doi.org/10/drx5

Zabalza Bribián, I., Aranda Usón, A., Scarpellini, S., 2009. Life cycle assessment in buildings: State-of-the-art and simplified LCA methodology as a complement for building certification. Build. Environ. 44, 2510-2520. https://doi.org/10/bxqx7w

Zabalza Bribián, I., Valero Capilla, A., Aranda Usón, A., 2011. Life cycle assessment of building materials: Comparative analysis of energy and environmental impacts and evaluation of the eco-efficiency improvement potential. Build. Environ. 46, 1133-1140. https://doi.org/10/ckjfm2 


\section{Aesthetic perception of photovoltaic integration within new proposals for ecological architecture}

(SUPPLEMENTARY INFORMATION DOCUMENT)

The main objective of this supplementary information document is to expand the knowledge of the prototypes evaluated. To this aim, some worksheets have been prepared, in which the following information concerning each prototype is showed:

- $\quad$ The Picture used for the surveys

- $\quad$ a. Name of the prototype

- b. Name of the team who developed this prototype.

- $\quad$ c. Type of Technology (c-Si: Crystalline silicon or TFSC: Thin-Film Solar Cell)

- d. Installed power (peak kWp)

- $\quad$ e. Location of the panels (façade, roof or both)

- $\quad$ f. Type of application (BIPV or BAPV)

- $\quad$ g. Appreciation category [1) the PV installation is seen, perceived and understood; 2) part of the PV installation is seen, perceived; and 3) the PV installation is not seen]

- $\quad$ Brief description of the PV system given to the respondents.

At the end of the document, a summary table shows the most significant data of the prototypes. 

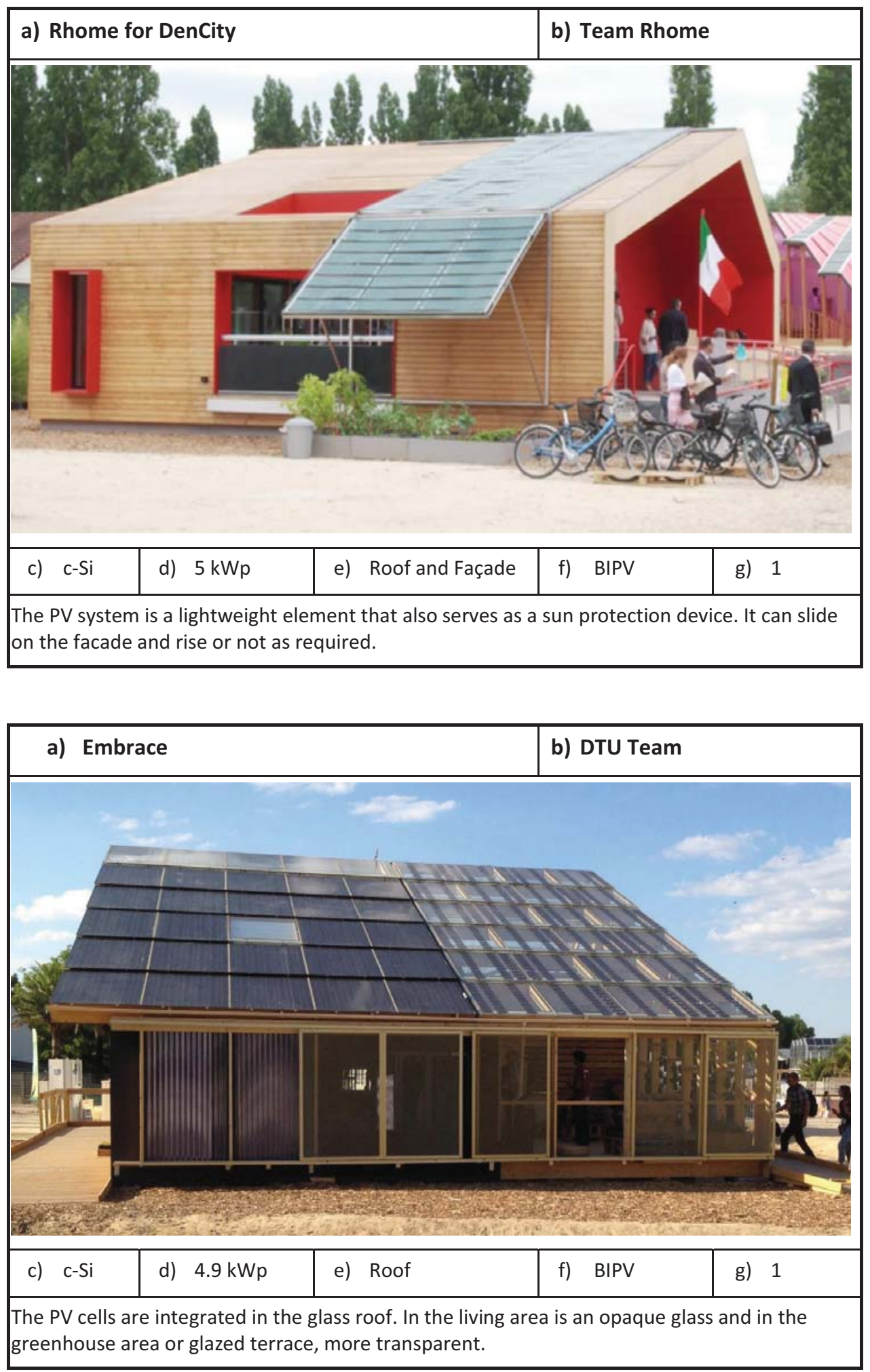

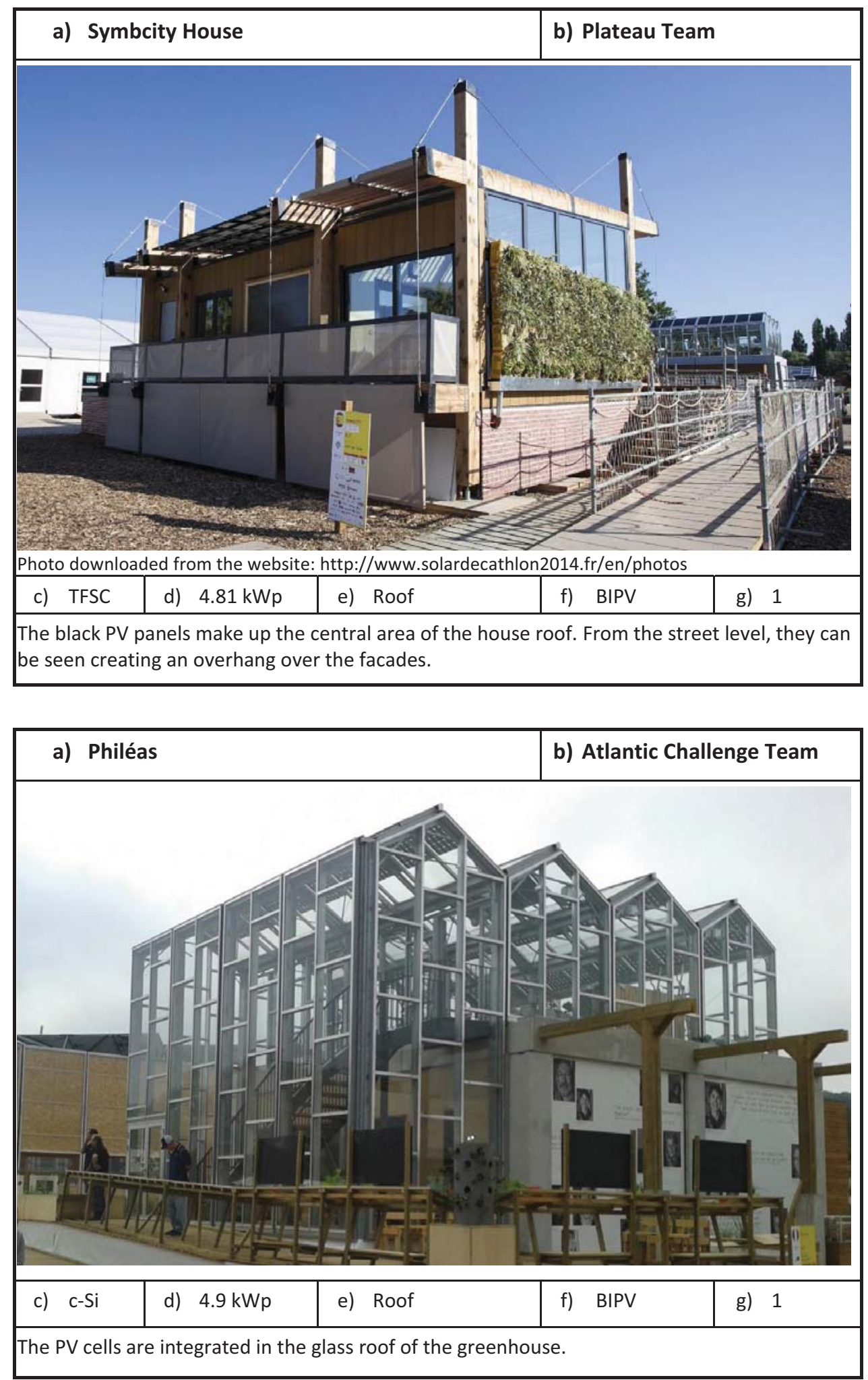

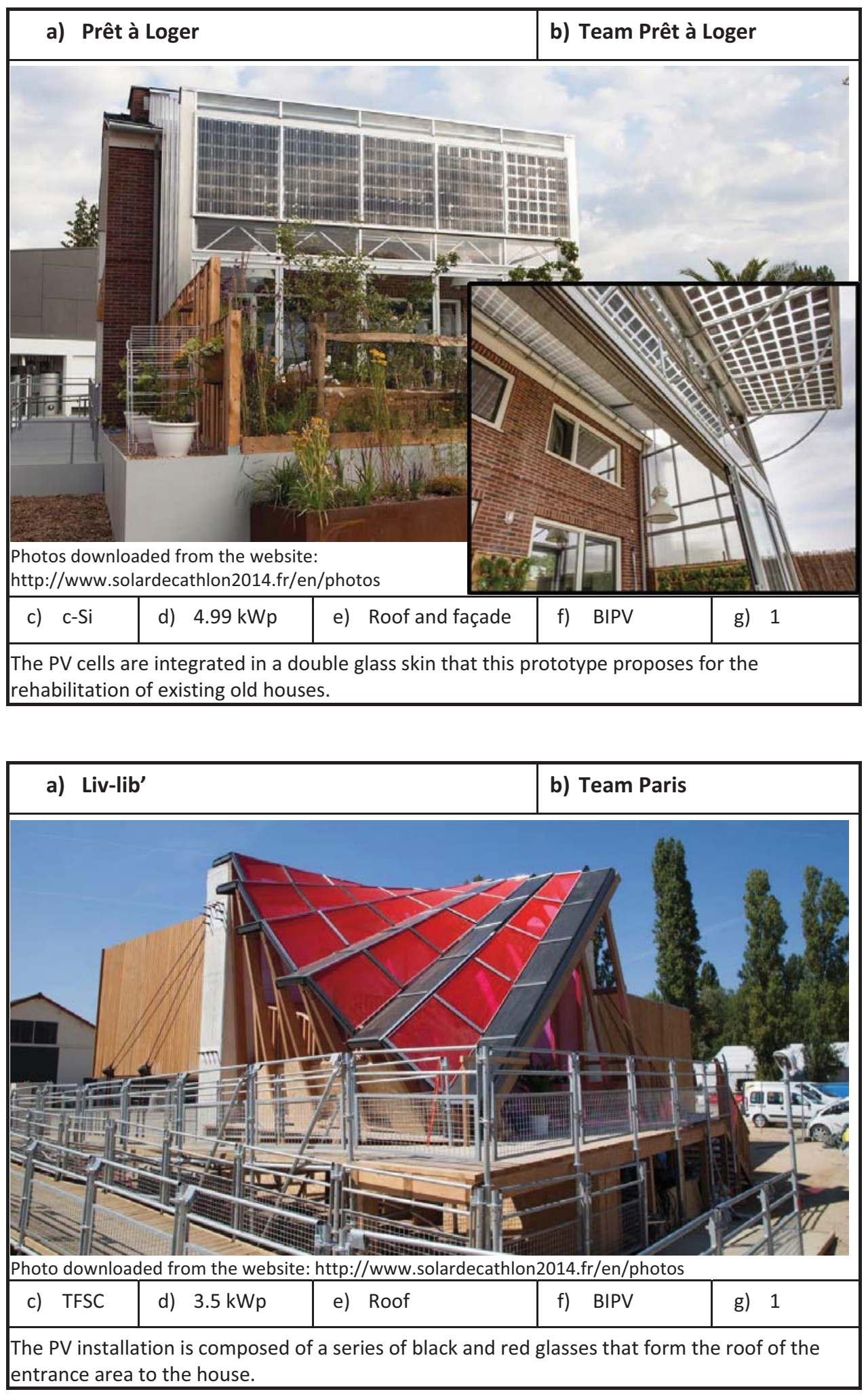

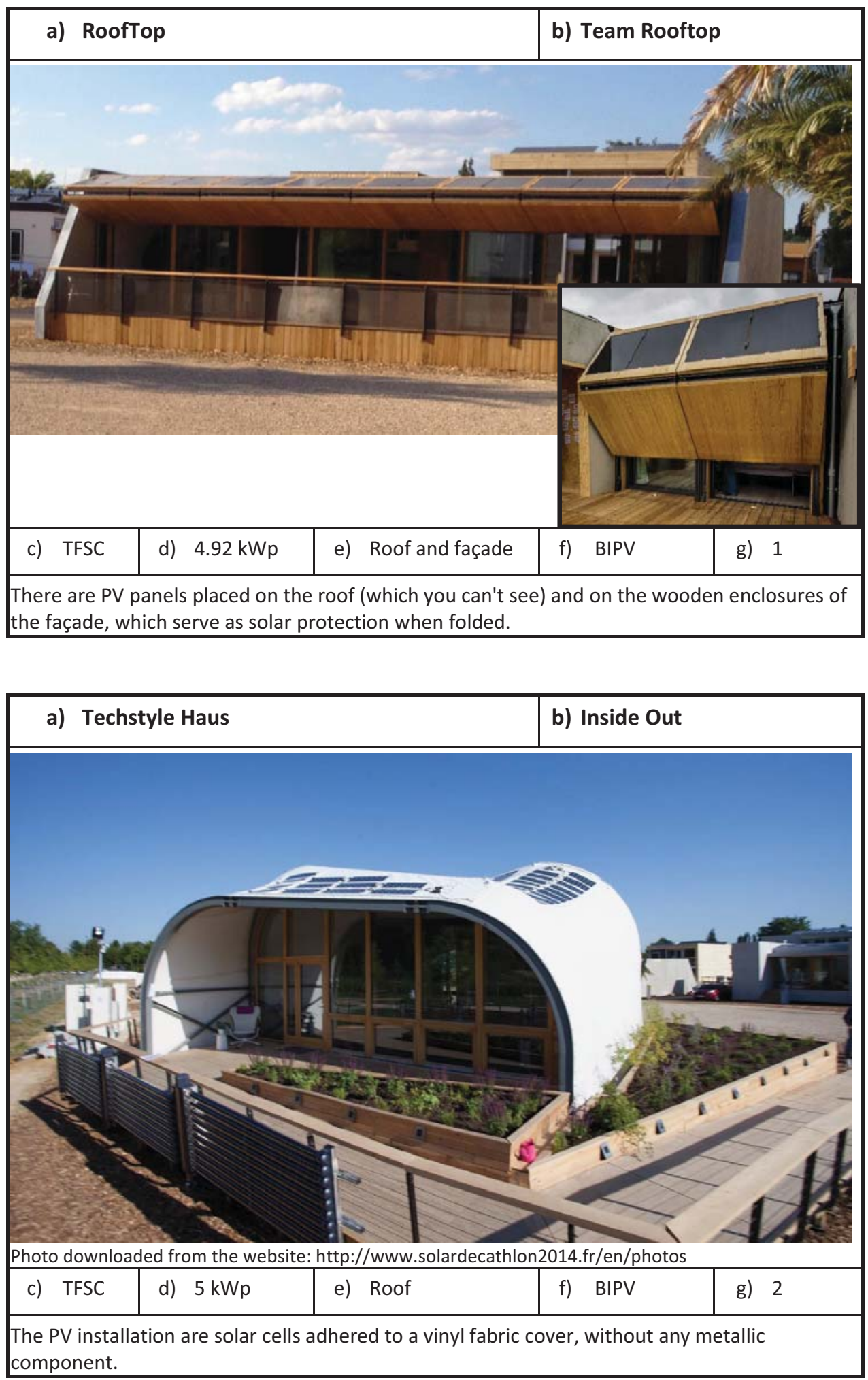

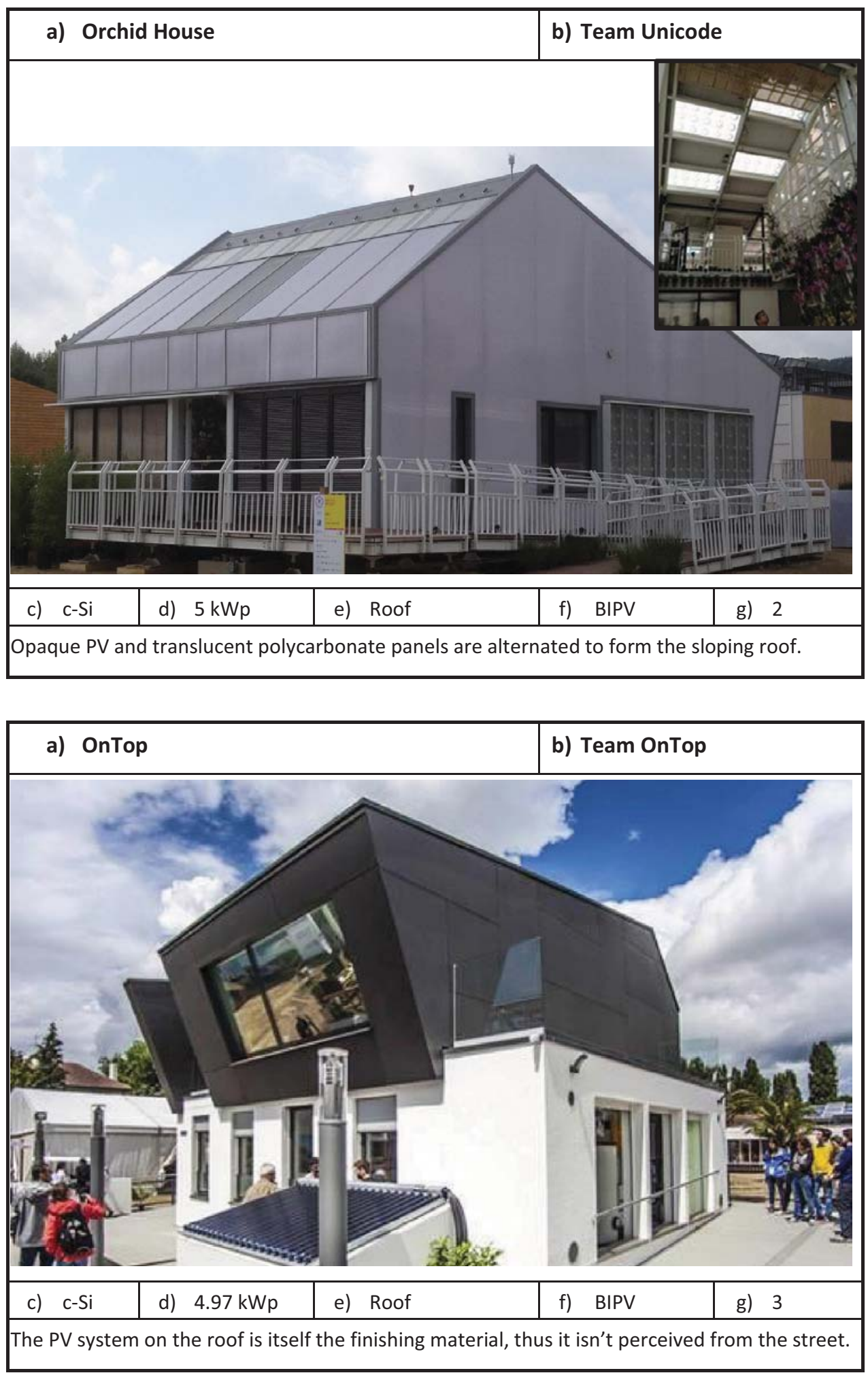

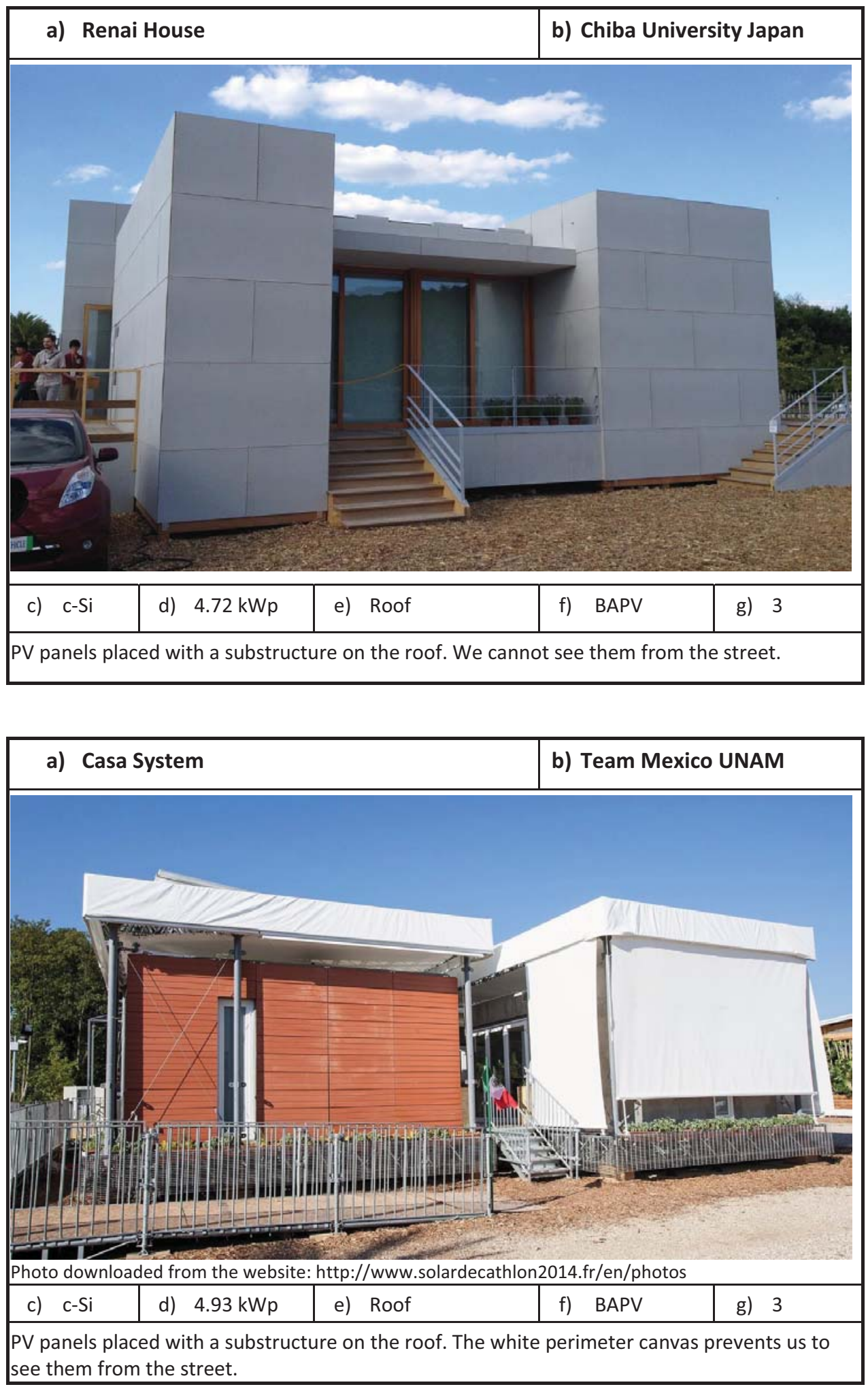

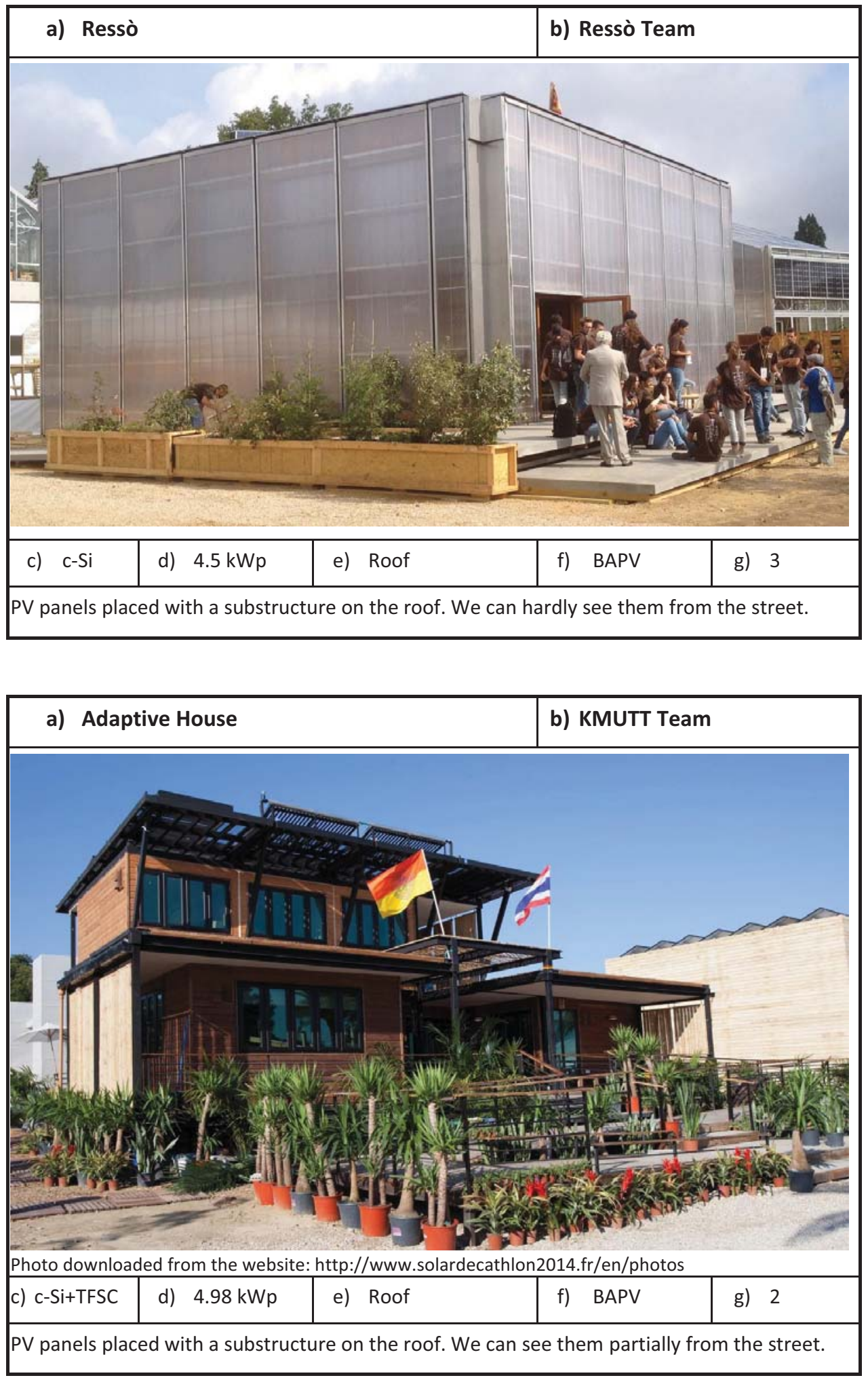

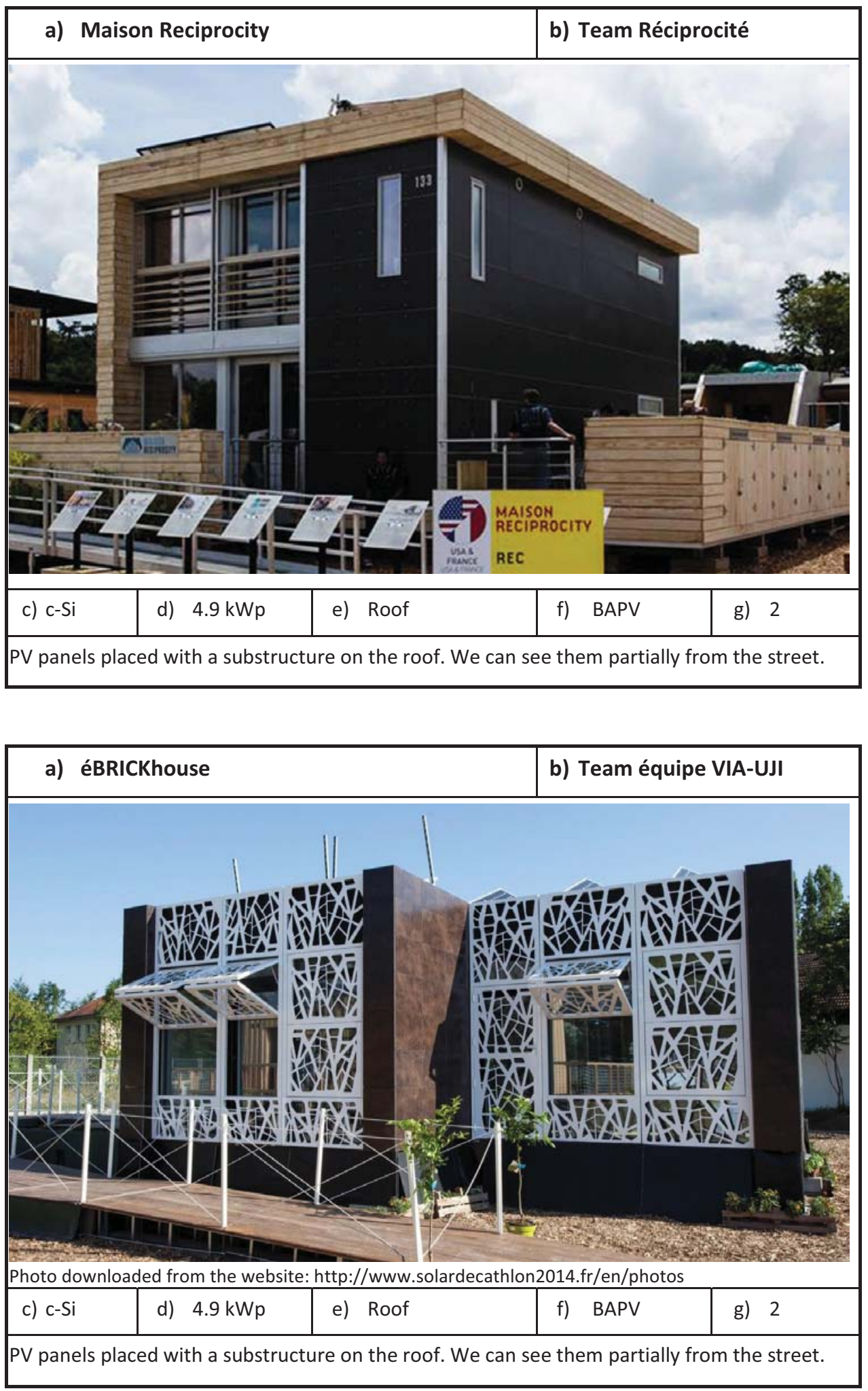

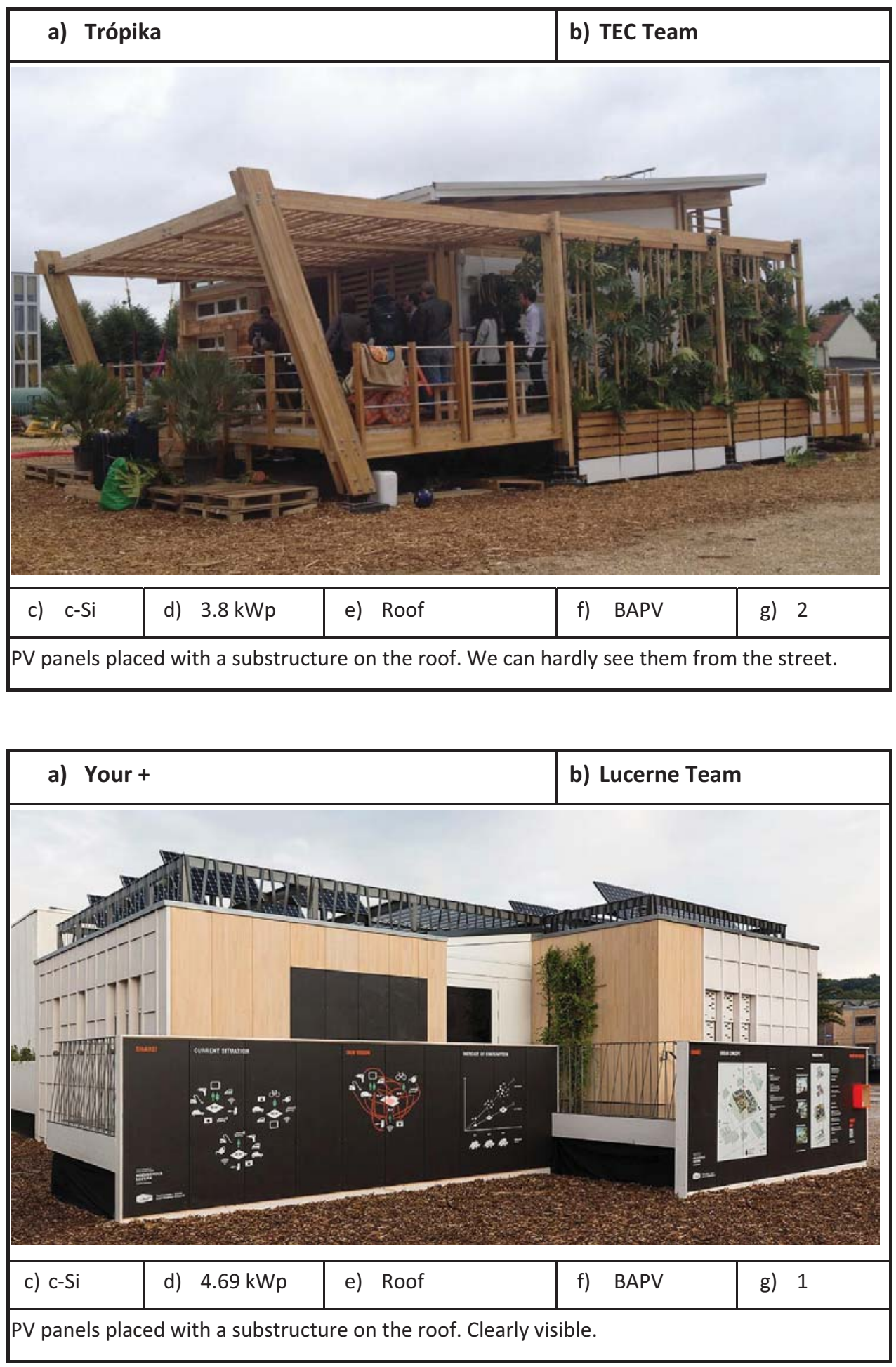

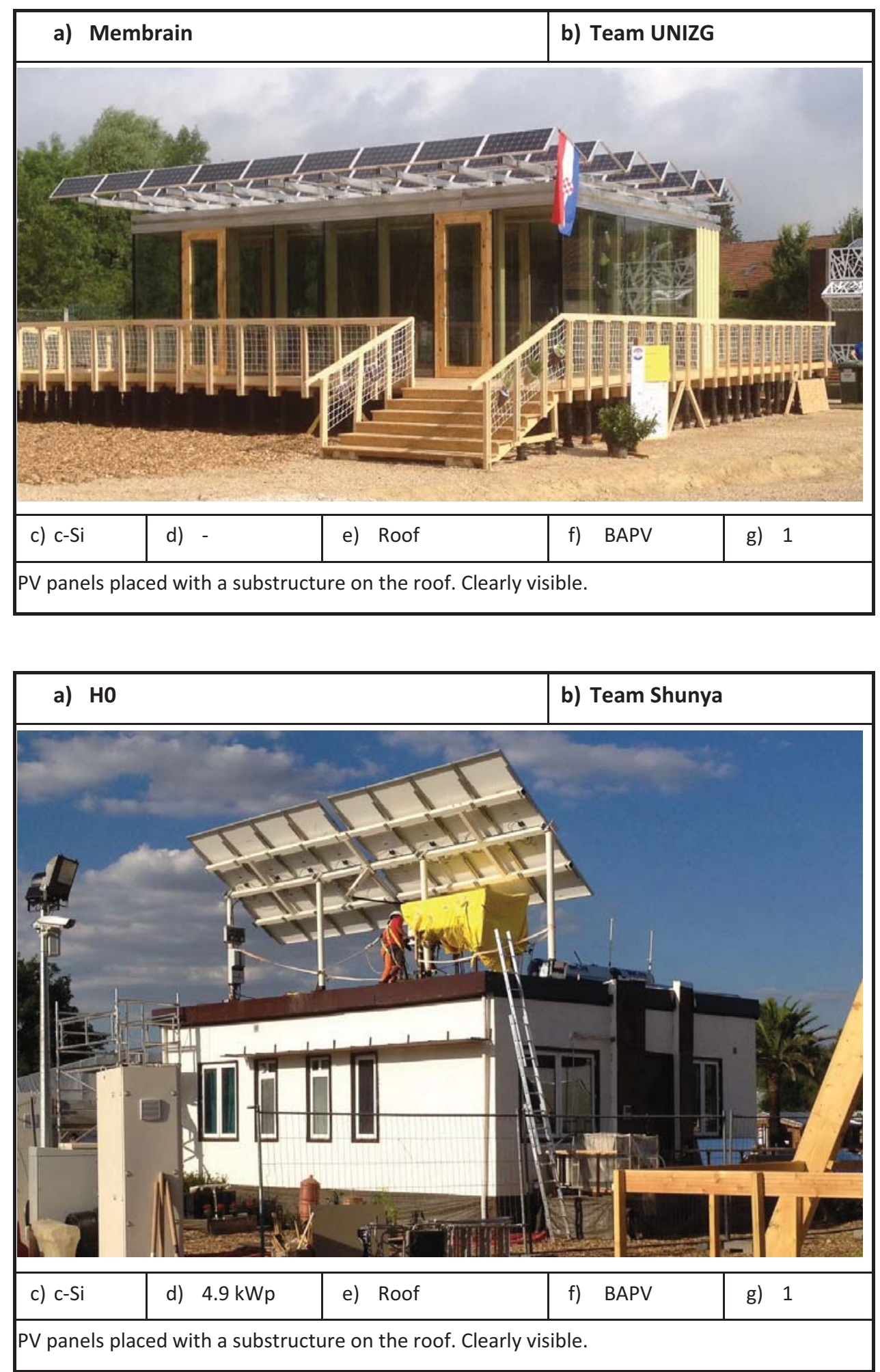


\section{SUMMARY TABLE}

\begin{tabular}{|c|c|c|c|c|c|}
\hline (a) & (c) & (d) & (e) & (f) & (g) \\
\hline PROTOTYPE & $\begin{array}{c}\text { Type of } \\
\text { technology }\end{array}$ & $\begin{array}{c}\text { Installed } \\
\text { power (kWp) }\end{array}$ & $\begin{array}{l}\text { Location of } \\
\text { the panels }\end{array}$ & $\begin{array}{c}\text { Type of } \\
\text { application }\end{array}$ & $\begin{array}{c}\text { Appreciation } \\
\text { category }\end{array}$ \\
\hline Rhome for DenCity & c-SI & 5 & $R+F$ & BIPV & 1 \\
\hline Embrace & c-Si & 4.9 & $\mathrm{R}$ & BIPV & 1 \\
\hline Symbcity & TFSC & 4.81 & $\mathrm{R}$ & BIPV & 1 \\
\hline Philéas & c-Si & 4.9 & $\mathrm{R}$ & BIPV & 1 \\
\hline Prêt à Loger & c-Si & 4.99 & $R+F$ & BIPV & 1 \\
\hline Liv-Lib' & TFSC & 3.5 & $\mathrm{R}$ & BIPV & 1 \\
\hline RoofTop & TFSC & 4.92 & $\mathrm{R}+\mathrm{F}$ & BIPV & 1 \\
\hline Techstyle Haus & TFSC & 5 & $\mathrm{R}$ & BIPV & 2 \\
\hline Orchid House & c-Si & 5 & $\mathrm{R}$ & BIPV & 2 \\
\hline OnTop & $\mathrm{c}-\mathrm{Si}$ & 4.97 & $\mathrm{R}$ & BIPV & 3 \\
\hline Renai House & $\mathrm{c}-\mathrm{Si}$ & 4.72 & $\mathrm{R}$ & BAPV & 3 \\
\hline Casa System & $\mathrm{c}-\mathrm{Si}$ & 4.93 & $\mathrm{R}$ & BAPV & 3 \\
\hline Ressò & $\mathrm{c}-\mathrm{Si}$ & 4.5 & $\mathrm{R}$ & BAPV & 3 \\
\hline Adaptive House & $\mathrm{c}-\mathrm{Si}+\mathrm{TFSC}$ & 4.98 & $\mathrm{R}$ & BAPV & 2 \\
\hline Maison Reciprocity & c-Si & 4.9 & $\mathrm{R}$ & BAPV & 2 \\
\hline ÉBRICKhouse & c-Si & 4.9 & $\mathrm{R}$ & BAPV & 2 \\
\hline Trópika & c-Si & 3.8 & $\mathrm{R}$ & BAPV & 2 \\
\hline Your + & c-Si & 4.69 & $\mathrm{R}$ & BAPV & 1 \\
\hline Membrain & c-Si & - & $\mathrm{R}$ & BAPV & 1 \\
\hline $\mathrm{HO}$ & c-Si & 4.9 & $\mathrm{R}$ & BAPV & 1 \\
\hline
\end{tabular}

Note: $\mathrm{c}-\mathrm{Si}=$ Crystalline silicon; $\mathrm{TFSC}=$ Thin-Film Solar Cell; $\mathrm{R}=$ roof; $\mathrm{F}=$ façade; $\mathrm{BIPV}=$ Building-integrated photovoltaics; BAPV = Building-applied photovoltaics; Appreciation category refers to the classification concerning the full, partial or nule perception and understanding of the photovoltaic installation, according to the angle or viewpoint of the street citizen. 


\title{
CAPÍtULO 4.
}

\section{ANALYSIS OF THE AESTHETIC PERCEPTION IN EUROPEAN-FUNDED PROJECTS WITH ACTUAL DEPLOYMENT OF RENEWABLE ENERGIES IN CITIES}

\author{
Núria Sánchez-Pantoja ${ }^{a,}{ }^{,}$, Rosario Vidal ${ }^{a}$, M. Carmen Pastor ${ }^{b}$ \\ a Department of Mechanical Engineering and Construction, GID, Universitat Jaume I, Av. Sos \\ Baynat s/n, 12071 Castellón, Spain. \\ ${ }^{b}$ Department of Basic and Clinical Psychology, and Psychobiology, Universitat Jaume I, Av. \\ Sos Baynat s/n, 12071 Castellón, Spain. \\ * Corresponding author: nbelengu@uji.es
}

\section{ABSTRACT}

Social acceptance and, to a lesser extent, the aesthetic impact of renewable energy integration in the city are topics scarcely considered in the literature but that have attracted growing interest in recent years. Innovative Europeanfunded projects, therefore, should start to consider these concepts. This paper provides, for the first time, a review of European projects carried out with the aim of identifying those with real implementation of renewable energies and energy storage systems in existing urban environments and their relationship with aesthetic perception. The search focused on the five most relevant programs related to renewable energies and climate change mitigation, including almost 14000 projects. The analysis of the results suggests low involvement in the real deployment of renewable energies on an urban scale but a trend for growth of potential projects since 2013. The study covered a wide range of technologies, with the most implemented being photovoltaic systems and lithium batteries. The discussion of the results considered their evolution over time, the political and geographical framework, and aesthetic aspects. The authors recommend that technological change should be associated with social change and consider technologies as basic products and core constituents of work and daily life.

\section{KEYWORDS}

Aesthetic impact, Solar Energy Systems, Renewable Energies, European projects, Urban Integration.

Abbreviations: ESS, Energy Storage System; PV, Photovoltaic; RES, Renewable Energy System; SES, Solar Energy System. 


\subsection{Introduction}

The fight to reduce the consequences of climate change has fostered implementation of renewable energies (EU, 2014a, 2010, 2003). First, renewable energy was in rural environments in the form of wind farms, photovoltaic plants or biomass plants, among others. Then, it was in urban environments, especially using solar energy systems in buildings (both thermal and photovoltaic) (Sánchez-Pantoja et al., 2018a). Research on the use of solar energy in buildings was very technical in the early years. The focus of interest was on optimization of the installation from the point of view of energy efficiency (D'Orazio et al., 2013; Loulas et al., 2012; Makrides et al., 2013, 2012, 2010) and the economic costs (Bonomo et al., 2017; Hemmerle and Hemmerle, 2016; Sagani et al., 2017; Yang and Zou, 2016). However, the integration of these technologies in the city is directly related to architecture, and consequently, not only optimization and cost are important but the aesthetics is an added factor that must be considered. In this sense, the focus in this line of work has recently moved to a more social approach, and aesthetic perception analysis has begun to be slowly introduced into this field of study. Several examples mention the aesthetic impact produced by solar energy systems in buildings and specifically the use of BIPV systems (Bao et al., 2017; Chen et al., 2013; Hille et al., 2018; Lu et al., 2018; Naspetti et al., 2016; Sánchez-Pantoja et al., 2018a; Strazzera and Statzu, 2017; Xu et al., 2017; Zhai and Williams, 2012). However, according to data on the European project, PVSITES (R2M et al., 2016), BIPV systems accounted for only $2.5 \%$ of PV worldwide in terms of installed capacity in 2016 and is expected to be approximately 6\% in 2019.

Based on the need to implement renewable energies as part of the struggle against climate change, the complexity of implementing energy models based exclusively on renewable energy systems has been emphasized by research in recent years. The main cause is that these energies generally depend on variable weather conditions, such as the sun or the wind, and therefore, it is not possible to guarantee a stable energy supply (Akinyele and Rayudu, 2014; Luo et al., 2015). It is not enough to build renewable energy plants or to be self-supplied with solar panels on the building itself. The energy transition needed to significantly reduce $\mathrm{CO}_{2}$ emissions requires the implementation of renewable energies on a neighborhood scale, including energy storage systems (ESS), and needs to provide a more efficient energy grid (Gößling-Reisemann et al., 2013; IRENA, 2017). According to the IRENA report, "the USA, China, Japan and Germany are leading the implementation of battery storage, while other countries, including Italy and South Korea, are following close behind" (IRENA, 2015). The need for long-term electricity storage systems, however, could be decreased in the future due to climate change (Wachsmuth et al., 2013).

In research focused on the use of renewable energies, a literature review suggests that the implementation of new energy models, including storage on a neighborhood scale, is addressed from a purely technical perspective. The greatest 
interest in ESS focuses on maximizing renewable resources (Akinyele and Rayudu, 2014; Amirante et al., 2017; Luo et al., 2015; Vlad et al., 2015). In the last few years, there is a growing need for a more social approach to the issue and for attention to be paid to the aesthetic impact of urban integration of renewable energy systems (RES) and related ESS on citizens, which has generally been overlooked. In fact, consultation and integration of affected persons, entities and sectors into the project are highly recommended to obtain social acceptance (Wachsmuth, 2015). Previous studies (Faiers and Neame, 2006; Strazzera and Statzu, 2017) stated that aesthetic characteristics were, among others, important influential elements in the choice of adopting PV systems. To this extent, studies were found that state that three dimensions are generally considered in this context: market, sociopolitical, and community (Devine-Wright et al., 2017). According to research by Aas et al. (2014), "acceptance can be empirically distinguished from support". An innovative study in this field was carried out by Devine-Wright et al. (2017), in which the social acceptance of renewable ESS was addressed but did not include any aesthetic impact assessment. At the scale of the building itself, the integration of the storage systems has been considered in several studies (Basecq et al., 2013; Rempel and Rempel, 2013; Ürge-Vorsatz et al., 2015), but as Navarro et al. state in their review (Navarro et al., 2016, 2015), formal and aesthetic integration into architectural design has not yet been fully developed commercially.

Energy transition and climate adaptation have been linked to the concept of resilience in recent research (Gleich et al., 2010; Ruth et al., 2015). This term invites innovative development to ensure continuity of services despite future uncertainties rather than a climate change protection stance (Wachsmuth, 2015). Nevertheless, it would be advisable to understand that aesthetic and social acceptance should be included in the term resilience, even though there is no roadmap for evaluation in the literature.

On the other hand, aesthetic impact is related to visual perception that could influence social acceptance, and its assessment focuses more on physical characteristics. There was a lack of consensus regarding the methods and the relevant physical factors that should be considered when assessing the aesthetic impact of renewable energy systems in the literature (Sánchez-Pantoja et al., 2018b). It could be even stated that there is no experimental literature in which ESSs are also included. In recent research, a methodological framework to assess the aesthetic impact of Solar Energy Systems (SES), both in rural and urban settings, was proposed to break down the aesthetic impact into three subimpacts: land use, SES and glare (Sánchez-Pantoja et al., 2018b). Regarding urban environments, the research concluded that visibility and degree of integration are the most influential factors, and when solar systems are included, glare is also relevant and depends on visibility. These results coincide with results from the study by Hille et al. (Hille et al., 2018), in which they stated, "homeowners would be willing to pay a premium of $21.79 \%$ for a roof with a BIPV plant installation versus a roof with a rack-mounted PV plant 
installation". Thus, homeowners preferred a perfectly integrated system. In addition, visibility was stated to be a key factor in improving social acceptance in other research (Florio et al., 2018).

Taking into account that the literature review revealed references to research into the social acceptance and aesthetic impact of the integration of renewable energies in cities, it conveyed that these concepts should be considered by innovative European projects in this field. In fact, the purpose of this work is, on the one hand, to identify European projects that have served, or currently serve, real implementation of RE with ESSs in the urban environments. On the other hand, they examined their relationship with aesthetic perception analysis. To this aim, an exhaustive review of European projects from the most relevant programs in the field of renewable energies and climate change was carried out. In addition, other factors, such as time, policy geographical frame and aesthetics, were considered.

\subsection{Method}

A systematic review of European projects was conducted in two consecutive phases. In the first phase, projects financed with funds from different agencies were searched using a series of filters with three successive steps to select only those projects that met the inclusion criteria established for our study (see Fig. 4. 1). In the second phase, additional data were collected through an electronic survey based on a validated questionnaire specifically designed for this study with the help of a group of experts from the Polytechnic University of Valencia (Spain).

For first phase, an online search for funded projects was carried out by focusing on European projects with real application of renewable energy on a neighborhood/district scale. This search was focused on 5 specific programs considered the most relevant to the promotion of renewable energies and climate change mitigation: (1) Interreg is a key instrument of the European Union to fund projects in fields such as health, environment, research, education, and sustainable energy, (2) Climate-KIC is a Knowledge and Innovation Community to support innovative initiatives that helps society mitigate and adapt to climate change, (3) the European Life Programme funds projects related to the environment and climate action, (4) FP7 was the European Union's Research and Innovation funding program until 2013, and (5) H2020 is the current European Union's Research and Innovation funding program. Those projects aimed to improve the network or that were located in rural environments or the sea or other projects in which energy was used for mobility or specific buildings (self-consumption) were excluded from our research. All projects written in English, Spanish, German, French, Italian and Portuguese were fully reviewed, whereas only keywords were checked for those written in other languages, such as Polish, Czech or Croatian. The overall methodology followed in our research is summarized in Fig. 4. 1, and the two phases of the study are described (i.e., the three filtering steps besides the follow-up surveys). 
The first search was performed in each of the five programs using specific keywords (renewable energies, urban energy storage systems, energy transition, cities development), topics (low-carbon economy, combating climate change and environment and resource efficiency for Interreg), and additional filters (energy domain with FP7-Energy and Energy-H2020 programs). Combining the 5 programs (i.e., Interreg, Life, Climate-KIC, FP7 and H2020), a total of 13989 projects were reviewed in the first screening.

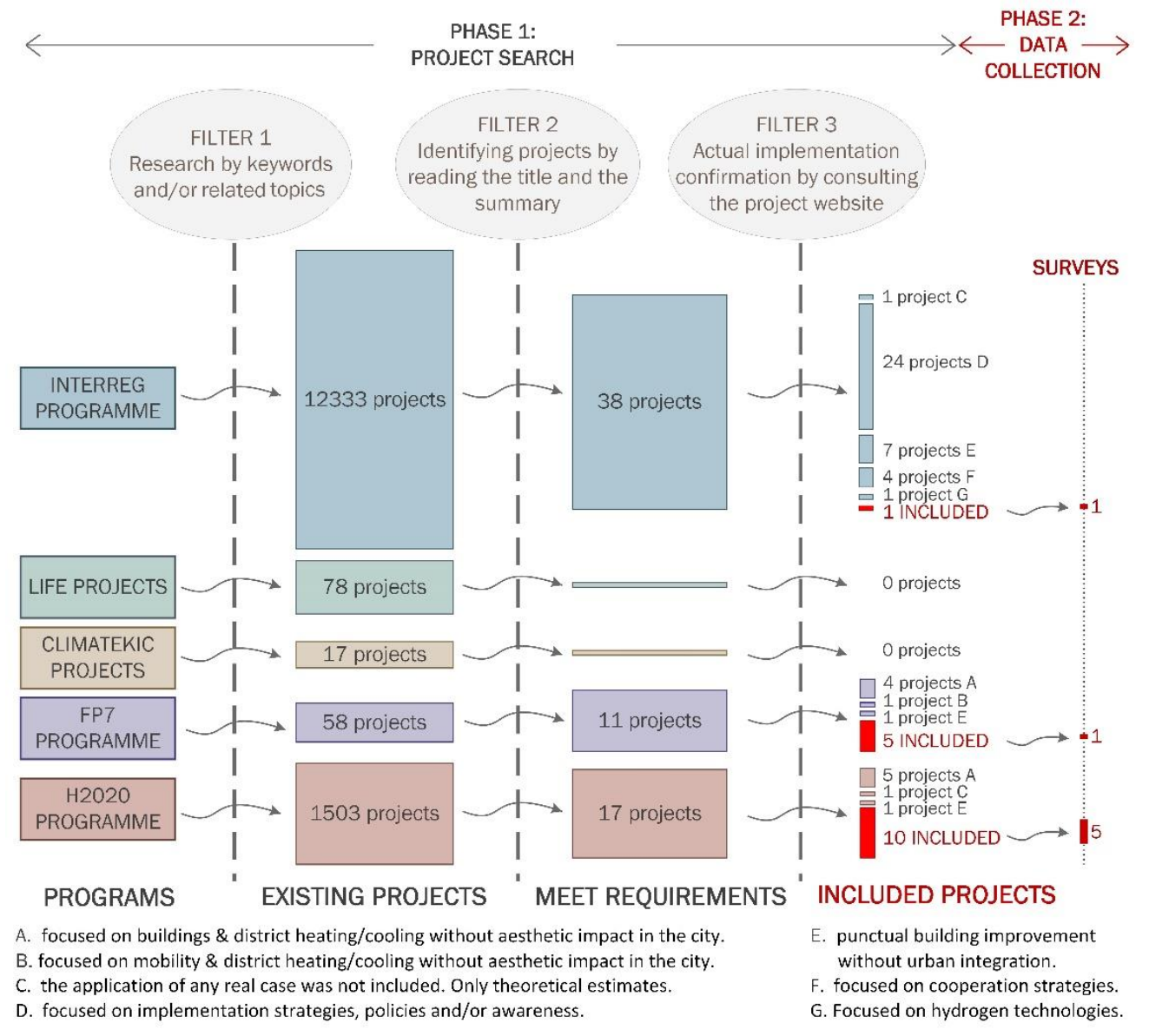

Fig. 4. 1 Methods of the research carried out in two phases. Phase 1: application of three successive filters according to the inclusion criteria. Phase 2: data collection through a survey. Letters $A$ to $G$ : reasons for not including a project in phase 2

In the second filtering step, the title and summary of each project were read to identify projects related to the implementation of renewable energies on an urban scale. As a result, 38 projects from the Interreg Program, 11 from FP7-Energy and 17 from the H2020 Program were selected because they were related to the main topic.

In the third filtering step, the websites of these 66 projects was consulted to obtain more information and to confirm whether the selected projects included real 
implementation of renewable energies on an urban scale. After applying this additional filter, a total of 16 funded projects in the survey conducted in the second phase of the study were selected. The rest of the projects were discarded for meeting any of the following exclusion criteria:

A. focused on buildings and district heating/cooling without aesthetic impact in the city,

B. focused on mobility and district heating/cooling without aesthetic impact in the city,

C. the application of any real case was not included, only theoretical estimates,

D. focused on implementation strategies, policies and/or awareness,

E. punctual building improvements and not urban integration,

F. focused on cooperation strategies, or

G. focused on hydrogen technologies.

The second phase of our study consisted in collecting additional information to compare projects. To this aim, a short survey was designed (see supplementary material) with specific questions about the facility features implemented throughout each project, including information about the specific type of renewable energy system and storage energy system implemented. Respondents could select from thermal solar, PV, wind energy, biofuels, hydroelectric power, geothermal energy, wave power or specify another option for renewable energy systems. They could choose from pumped hydro storage, compressed air energy storage, flywheels, supercapacitors, redox flow batteries, lithium batteries, hydrogen storage or specify another option for storage systems. The content of the questions was validated with a group of experts from the Energy Engineering Institute at the Polytechnic University of Valencia.

To this extent, the data collection process implemented during this second phase was rather complex because almost $70 \%$ of the projects were not yet completed at the time. Therefore, certain information was difficult to collect as several entities were unwilling or unable to participate by providing relevant data. At the end of the survey process, a series of interviews (via email or telephone) were conducted by the first author. Information corresponding to six European projects, including seven districts as real demonstrations, were collected.

\subsection{Data collection}

The results are summarized separately for the different programs explored in this study. Table 4. 1 shows the findings for the Interreg program, Table 4. 2 shows FP7, and Table 4. 3 shows the H2020 Program. The results from Life and Climate-KIC Programs are not shown in tables since no projects were identified as being related to the implementation of renewable energies on an urban scale. Overall, low 
involvement in the real implementation of renewable energies on an urban scale was revealed in European projects by these data.

Table 4. 1 Results for projects corresponding to the Interreg Program

\begin{tabular}{|c|c|c|c|c|c|}
\hline $\begin{array}{l}\text { AREA/NUM. PROJECTS } \\
\text { REVISED IN THE AREA }\end{array}$ & & $\begin{array}{l}\text { Identified } \\
\text { Projects }\end{array}$ & ACRONYM & $\begin{array}{l}\text { PROGRAM } \\
\text { PERIOD }\end{array}$ & $\begin{array}{l}\text { Reason } \\
\text { for } \\
\text { noninclus } \\
\text { ion }\end{array}$ \\
\hline Europe & 204 & 1 & RENERGY & 2007-2013 & $\mathrm{D}$ \\
\hline $\begin{array}{l}\text { Northern Periphery } \\
\text { and Arctic }\end{array}$ & 86 & 0 & None & & \\
\hline CBC Hungary-Serbia & 203 & 0 & None & & \\
\hline $\begin{array}{l}\text { Vlaanderen- } \\
\text { Nederland }\end{array}$ & 193 & 0 & None & & \\
\hline $\begin{array}{l}\text { V-A Hungary-Croatia } \\
\text { Coop. Progr. }\end{array}$ & 162 & 0 & None & & \\
\hline Sweden-Norway & 376 & 0 & None & & \\
\hline SUDOE & 36 & 0 & None & & \\
\hline South Baltic & 135 & 0 & None & & \\
\hline Slovenia-Hungary & 11 & 0 & None & & \\
\hline Slovenia-Croatia & 20 & 0 & None & & \\
\hline Slovenia-Austria & 139 & 0 & None & & \\
\hline Slovakia Hungary & 59 & 0 & None & & \\
\hline $\begin{array}{l}\text { Slovakia-Czech } \\
\text { Republic }\end{array}$ & 280 & 0 & None & & \\
\hline Slovakia-Austria & 107 & 0 & None & & \\
\hline \multirow{2}{*}{ Romania-Hungary } & \multirow{2}{*}{662} & \multirow{2}{*}{2} & Geotherm & 2007-2013 & $\mathrm{D}$ \\
\hline & & & GEO THERMIC & $2007-2013$ & $\mathrm{D}$ \\
\hline Romania-Bulgaria & 152 & 0 & None & & \\
\hline $\begin{array}{l}\text { Rhin supérieur- } \\
\text { Oberrhein }\end{array}$ & 39 & 0 & None & & \\
\hline Poland-Slovakia & 7 & 0 & None & & \\
\hline $\begin{array}{l}\text { Poland- } \\
\text { Germany/Saxony }\end{array}$ & 142 & 0 & None & & \\
\hline \multirow{2}{*}{$\begin{array}{l}\text { POCTEP (Spain- } \\
\text { Portugal) }\end{array}$} & \multirow{2}{*}{236} & \multirow{2}{*}{2} & 0317_ALTERCEXA_4_E & $2007-2013$ & $\mathrm{D}$ \\
\hline & & & 0062_RETALER_6_E & $2007-2013$ & $\mathrm{D}$ \\
\hline $\begin{array}{l}\text { POCTEFA } \\
\text { (Spain/France/Ando } \\
\text { rra) }\end{array}$ & 133 & 0 & None & & \\
\hline $\begin{array}{l}\text { Öresund-Kattegat- } \\
\text { Skagerrak }\end{array}$ & 128 & 0 & None & & \\
\hline $\begin{array}{l}\text { Northern Ireland- } \\
\text { Ireland-Scotland } \\
\text { (UK-Ireland) }\end{array}$ & 87 & 1 & SPIRE & 2007-2013 & $\mathrm{D}$ \\
\hline \multirow{2}{*}{ North-West Europe } & \multirow{2}{*}{55} & \multirow{2}{*}{2} & GenComm & $2014-2020$ & $\mathrm{G}$ \\
\hline & & & HeatNet NWE & $2016-2020$ & INCLUDED \\
\hline
\end{tabular}




\begin{tabular}{|c|c|c|c|c|c|}
\hline North Sea Region & 148 & 1 & North Sea - SEP & 2007-2013 & $\mathrm{D}$ \\
\hline $\begin{array}{l}\text { Nord (Sweden - } \\
\text { Finland-Norway) }\end{array}$ & 236 & 0 & None & & \\
\hline Mediterranean & 159 & 0 & None & & \\
\hline $\begin{array}{l}\text { Madeira-Açores- } \\
\text { Canarias (MAC) }\end{array}$ & 293 & 1 & ERAMAC-2 & 2000-2006 & $\mathrm{D}$ \\
\hline Lithuania-Poland & 245 & 0 & None & & \\
\hline \multirow{2}{*}{ Latvia-Lithuania } & \multirow{2}{*}{270} & \multirow{2}{*}{2} & Solar Think Tank & 2007-2013 & $\mathrm{D}$ \\
\hline & & & Renewable energy & 2007-2013 & $E$ \\
\hline \multirow{2}{*}{ Italy-Switzerland } & \multirow{2}{*}{215} & \multirow{2}{*}{2} & PV-Alps & $2007-2013$ & $\mathrm{D}$ \\
\hline & & & Innovazione Energetica & 2007-2013 & $\mathrm{D}$ \\
\hline Italy-Slovenia & 336 & 1 & ENRI & $2007-2013$ & $E$ \\
\hline Italy-Malta & 37 & 1 & RESI & $2007-2013$ & $\mathrm{D}$ \\
\hline Italy-France & 271 & & None & & \\
\hline Italy-Austria & 216 & 1 & ALTER VIS & $2007-2013$ & $\mathrm{D}$ \\
\hline Ireland-Wales & 41 & 0 & None & & \\
\hline $\begin{array}{l}\text { IPA CBC } \\
\text { Romania-Serbia }\end{array}$ & 48 & 1 & $\begin{array}{l}\text { Energy Efficiency - The } \\
\text { Premise of a Better } \\
\text { Environment }\end{array}$ & 2014-2020 & $\mathrm{E}$ \\
\hline $\begin{array}{l}\text { IPA CBC Greece-The } \\
\text { former Yugoslav } \\
\text { Republic of } \\
\text { Macedonia }\end{array}$ & 38 & 1 & PEEBPE & 2007-2013 & $E$ \\
\hline $\begin{array}{l}\text { IPA CBC Bulgaria- } \\
\text { Turkey }\end{array}$ & 63 & 0 & None & & \\
\hline Indian Ocean & 15 & 0 & None & & \\
\hline $\begin{array}{l}\text { IPA CBC Bulgaria- } \\
\text { The Former Yugoslav } \\
\text { Republic of } \\
\text { Macedonia }\end{array}$ & 70 & 1 & $\begin{array}{l}\text { Cross-border } \\
\text { cooperation in the } \\
\text { field of RE Sources and } \\
\text { Energy Efficiency }\end{array}$ & 2007-2013 & $\mathrm{F}$ \\
\hline Greece-Italy & 112 & 0 & None & & \\
\hline Greece-Cyprus & 82 & 1 & ENEPГEIN & $2007-2013$ & $E$ \\
\hline Greece-Bulgaria & 114 & 1 & ENERGEIA & 2007-2013 & $\mathrm{C}$ \\
\hline \multirow{2}{*}{$\begin{array}{l}\text { Grande } \\
\text { Région/Großregion }\end{array}$} & \multirow{2}{*}{170} & \multirow{2}{*}{2} & VallEnergie & $2007-2013$ & $\mathrm{~F}$ \\
\hline & & & ENEFF & $2007-2013$ & $\mathrm{~F}$ \\
\hline $\begin{array}{l}\text { Germany/Saxony- } \\
\text { Czech Republic }\end{array}$ & 164 & 1 & ENA1 & $2007-2013$ & $\mathrm{~F}$ \\
\hline $\begin{array}{l}\text { Germany/Bavaria- } \\
\text { Czech Republic }\end{array}$ & 222 & 0 & None & & \\
\hline $\begin{array}{l}\text { Germany/Mecklenb } \\
\text { urg-Western } \\
\text { Pomerania/Branden } \\
\text { burg-Poland }\end{array}$ & 190 & 0 & None & & \\
\hline $\begin{array}{l}\text { Germany/Brandenb } \\
\text { urg-Poland }\end{array}$ & 84 & 0 & None & & \\
\hline Germany-Denmark & 206 & 0 & None & & \\
\hline \multirow{2}{*}{$\begin{array}{l}\text { France (Channel) } \\
\text { England }\end{array}$} & \multirow{2}{*}{327} & \multirow{2}{*}{3} & SEACS & 2007-2013 & $\mathrm{D}$ \\
\hline & & & ECO FAB 2 & $2007-2013$ & $\mathrm{D}$ \\
\hline
\end{tabular}




\begin{tabular}{|c|c|c|c|c|c|}
\hline & & & $\begin{array}{l}\text { Affordable } \\
\text { Sustainable Housing }\end{array}$ & $2000-2006$ & $\mathrm{D}$ \\
\hline $\begin{array}{l}\text { France-Wallonie- } \\
\text { Vlaanderen }\end{array}$ & 202 & 1 & $\begin{array}{l}\text { Sustainable Energy } \\
\text { Management }\end{array}$ & $2007-2013$ & $E$ \\
\hline France-Switzerland & 218 & 1 & $\begin{array}{l}\text { Les énergies } \\
\text { renouvelables au } \\
\text { service du } \\
\text { développement } \\
\text { durable }\end{array}$ & $2000-2006$ & $\mathrm{D}$ \\
\hline Estonia-Latvia & 150 & 0 & None & & \\
\hline \multirow{2}{*}{ DE-NL } & \multirow{2}{*}{705} & \multirow{2}{*}{2} & $\begin{array}{l}\text { Energie ohne Grenzen } \\
- \text { II-04=097 }\end{array}$ & 2007-2013 & $\mathrm{D}$ \\
\hline & & & $\begin{array}{l}\text { Cleantech Energy } \\
\text { Crossing }\end{array}$ & $2014-2020$ & $\mathrm{D}$ \\
\hline $\begin{array}{l}\text { Czech Republic- } \\
\text { oland }\end{array}$ & 726 & 0 & None & & \\
\hline \multirow{4}{*}{ Central Europe } & \multirow{4}{*}{209} & \multirow{4}{*}{4} & ENERGYREGION & 2007-2013 & $\mathrm{D}$ \\
\hline & & & EnSURE & $2007-2013$ & $\mathrm{D}$ \\
\hline & & & CoP & 2007-2013 & $\mathrm{D}$ \\
\hline & & & CEC5 & 2007-2013 & $\mathrm{E}$ \\
\hline Central Baltic & 219 & 0 & None & & \\
\hline Botnia-Atlantica & 64 & 0 & None & & \\
\hline Baltic Sea Region & 19 & 0 & None & & \\
\hline Austria-Hungary & 133 & 0 & None & & \\
\hline Austria-Germany & 125 & 0 & None & & \\
\hline $\begin{array}{l}\text { Austria-Czech } \\
\text { Republic }\end{array}$ & 604 & 0 & None & & \\
\hline Atlantic Area & 70 & 0 & None & & \\
\hline Alpine Space & 49 & 0 & None & & \\
\hline $\begin{array}{l}\text { Alpenrhein- } \\
\text { Bodensee- } \\
\text { Hochrhein } \\
\text { (DE/AT/CH/FL) }\end{array}$ & 225 & 0 & None & & \\
\hline $\begin{array}{l}\text { ALCOTRA (France- } \\
\text { Italy) }\end{array}$ & 417 & 0 & None & & \\
\hline \multirow{2}{*}{$\begin{array}{ll}\text { ADRION } & \text { (Adriatic } \\
\text { lonian) } & \\
\end{array}$} & \multirow{2}{*}{65} & \multirow{2}{*}{2} & SEA-R & 2007-2013 & $\mathrm{D}$ \\
\hline & & & Adriacold & 2007-2013 & $\mathrm{D}$ \\
\hline 2 Seas & 109 & 0 & None & & \\
\hline
\end{tabular}

\section{Total Projects: $12333 \quad 38$}


Table 4. 2 Results for projects corresponding to the FP7 Program

\begin{tabular}{|c|c|c|c|c|c|c|}
\hline $\begin{array}{l}\text { SUB- } \\
\text { PROGRAM }\end{array}$ & $\begin{array}{l}\text { FILTER/NUM. } \\
\text { PROJECTS } \\
\text { REVISED }\end{array}$ & & $\begin{array}{l}\text { Identified } \\
\text { Projects }\end{array}$ & ACRONYM & $\begin{array}{l}\text { PROGRAM } \\
\text { PERIOD }\end{array}$ & $\begin{array}{l}\text { Reason for } \\
\text { noninclusi } \\
\text { on }\end{array}$ \\
\hline \multirow{11}{*}{ FP7 } & \multirow{11}{*}{$\begin{array}{l}\text { ENERGY- } \\
\text { Specific } \\
\text { Program } \\
\text { "Cooperation": } \\
\text { Energy }\end{array}$} & \multirow{11}{*}{58} & 1 & ECO-Life & 2010-2016 & INCLUDED \\
\hline & & & 1 & SOLUTION & $2009-2014$ & $A$ \\
\hline & & & 1 & BEEM-UP & 2011-2014 & $E$ \\
\hline & & & 1 & CELSIUS & 2013-2017 & $A$ \\
\hline & & & 1 & CITY-ZEN & 2014-2019 & INCLUDED \\
\hline & & & 1 & CITyFiED & 2014-2019 & INCLUDED \\
\hline & & & 1 & READY & 2014-2019 & A \\
\hline & & & 1 & SINFONIA & 2014-2019 & A \\
\hline & & & 1 & R2CITIES & 2014-2018 & INCLUDED \\
\hline & & & 1 & ZenN & 2013-2018 & INCLUDED \\
\hline & & & 1 & PITAGORAS & 2013-2017 & $B$ \\
\hline
\end{tabular}

Total Projects: 58

11

Table 4. 3 Results for projects corresponding to the H2O2O Program

\begin{tabular}{|c|c|c|c|c|c|c|}
\hline $\begin{array}{l}\text { SUB- } \\
\text { PROGRAM }\end{array}$ & $\begin{array}{l}\text { FILTER/NUM. } \\
\text { PROJECTS } \\
\text { REVISED }\end{array}$ & & $\begin{array}{l}\text { Identified } \\
\text { Projects }\end{array}$ & ACRONYM & $\begin{array}{l}\text { PROGRAM } \\
\text { PERIOD }\end{array}$ & $\begin{array}{l}\text { Reason for } \\
\text { noninclusi } \\
\text { on }\end{array}$ \\
\hline $\begin{array}{l}\text { EU IEE } \\
\text { PROJECTS }\end{array}$ & $\begin{array}{l}\text { Electricity } \\
\text { production \& } \\
\text { RE (ALTENER) }\end{array}$ & 252 & 1 & WINEUR & 2005-2007 & INCLUDED \\
\hline \multicolumn{2}{|c|}{ Energy - renewable energy } & 103 & 1 & EOLI FPS & 2018 & $\mathrm{C}$ \\
\hline \multirow{15}{*}{\multicolumn{2}{|c|}{$\begin{array}{l}\text { EU.3.3. - } \\
\text { SOCIETAL } \\
\text { CHALLENGES - } \\
\text { Secure, clean and } \\
\text { energy efficiency }\end{array}$}} & \multirow{15}{*}{1148} & 1 & GrowSmarter & $2015-2020$ & INCLUDED \\
\hline & & & 1 & REMOURBAN & $2015-2019$ & INCLUDED \\
\hline & & & 1 & FLEXINETS & $2015-2018$ & $\mathrm{~A}$ \\
\hline & & & 1 & INDIGO & $2015-2020$ & A \\
\hline & & & 1 & IRIS & $2017-2022$ & INCLUDED \\
\hline & & & 1 & CITYKEYS & 2015-2017 & INCLUDED \\
\hline & & & 1 & Sharing Cities & $2016-2020$ & INCLUDED \\
\hline & & & 1 & StepUP & 2019-2023 & $\mathrm{E}$ \\
\hline & & & 1 & RELaTED & 2016-2021 & A \\
\hline & & & 1 & OPTi & $2015-2017$ & A \\
\hline & & & 1 & REPLICATE & $2016-2021$ & $\mathrm{~A}$ \\
\hline & & & 1 & SmartEnCity & 2016-2021 & INCLUDED \\
\hline & & & 1 & $\begin{array}{l}\text { SMARTER } \\
\text { TOGETHER }\end{array}$ & 2016-2021 & INCLUDED \\
\hline & & & 1 & MAtchUP & $2017-2022$ & INCLUDED \\
\hline & & & 1 & STARDUST & $2017-2021$ & INCLUDED \\
\hline
\end{tabular}


For each specific area or topic, the above tables show the following information: (a) number of existing projects (Filter 1 ), (b) how many projects were identified related to the implementation of RE on an urban scale (Filter 2), (c) acronyms, (d) program period to which they belong, and (e) the established inclusion and exclusion criteria (Filter 3). Eventually, 16 out of 13989 reviewed projects met the requirements: 1 project in the Interreg Program (see Table 4. 1), 5 projects in the FP7 Program (see Table 4. 2), and 10 projects in the H2020 Program (see Table 4. 3).

Regarding the LIFE program, the established inclusion criteria were not met by any funded projects. Indeed, all projects were focused on the field of technology development and mainly applied to mobility issues. As far as buildings, only funded projects for specific public buildings were found in our search. Nothing was found on an urban scale.

For the Climate-KIC program, the search was carried out using keywords: renewable energy/ies, urban energy storage, energy transition, and city development. Unfortunately, no research project that applied renewable energies on an urban scale was found.

Specifically, for the Interreg Program (see Table 4. 1), certain projects focused on strategy development or policies designed to encourage the implementation of RE, such as the Low carbon (plan) project, were found. Projects focused on punctual integration of RE within buildings were also found, but these projects were discarded because they did not carry out real implementation on an urban scale.

Concerning the EU FP7-Energy Program (see Table 4. 2), the European projects browser, cordis.europa.eu, was used applying the following filters: projects, Energy, and FP7-Energy. The FP7 call contained many projects meeting the criteria established for the search, but the overall requirements were met only by a few. Thus, some projects were focused on the improvement of existing buildings or the construction of new efficient buildings. However, they were not able to act at the district or neighborhood level (e.g., NEED4B, E2REBUILD, EU-GUGLE, etc.). In addition, the Pitagoras, Sinfonia and Flexinets projects, among others, improved heating or cooling systems at the district level, but recovery of residual heat does not require an aesthetic integration of the installation at an urban level. Therefore, such projects were also excluded from this study.

Finally, for the EU H2020 Program (see Table 4. 3), the same browser, cordis.europa.eu, was also used in the search. In particular, projects that met the criteria defined a priori in our study were included by the H2020-UE.3.3 research line. However, most of the reviewed projects focused on new technology development (e.g., SWInG, FlexHyJoin, CHEOPS, INCOVER), monitoring, management, and optimization of installations (e.g., SYMBIOPTIMA, MOSES, OPTi, TOPAs), or energy efficiency improvement and low consumption, without acting at 
the community level but building to building (e.g., REnnovates, TRANSITION ZERO, REFURB, NewTREND). In addition, for the Intelligent Energy Europe (IEE) research line in the H2020 Program, a large number of funded projects focused on biofuels or in collective heating and cooling systems were found that were finally dismissed for failing to consider the aesthetic impact on the cities, (e.g., REnnovates, TRANSITION ZERO, REFURB, NewTREND). For this reason, the complete requirements in our study were met only by one project from this program.

\subsubsection{Survey results}

During the data collection process conducted in phase two, the focus was on the 16 selected projects, 11 ongoing projects and 5 completed projects. Of the ongoing projects, 5 responded to the survey (45\%), whereas of the completed projects, only 1 responded (25\%). Of the 16 selected projects, 37\% completed the survey, from which interesting data about the implemented technologies can be reported. Descriptive information regarding the respondents to the survey can be summarized into 6 projects and 7 cities as follows (acronym of the project, city and country, program period):

ECO-Life - Høje-Taastrup, Denmark. 2010-2016

HeatNET NEW - Boulogne-Sur-Mer, France. 2016-2020 (ongoing project)

Remourban - Nottingham, UK. 2015-2019 (ongoing project)

GrowSmarter - Cologne, Germany. 2015-2020 (ongoing project)

Smarter Together 1 - Lyon, France. 2016-2021 (ongoing project)

Smarter Together 2 - Munich, Germany.2016-2021 (ongoing project)

SmartEnCity - Vitoria-Gasteiz, Spain. 2016-2021 (ongoing project)

Clearly, as shown in Table 4. 4, the most implemented RES (71\%) was research projects focused on photovoltaic systems. To a lesser extent, our findings suggest that implementations of solar thermal, biomass and/or geothermal energy systems have been common (43\%) but always accompanied by photovoltaic systems. Wind energy systems were used in a unique project that was already completed and never integrated within the built urban environment. Biofuels and hydroelectric and wave power are systems never used in integration projects on an urban scale. On the other hand, the use of energy storage systems has not been massively widespread (43\%) as they are more recent and usually associated with solar energy systems, with lithium batteries as the most common type. Storage systems such as compressed air, flywheels, supercapacitors, redox flow batteries or hydrogen were never used in any study. In addition, other relevant information such as the price of the energy generated with the installed systems was difficult to obtain through the electronic survey. 
Table 4. 4 Renewable Energy Systems and Energy Storage Systems used in the projects participating in the survey.

\section{Renewable Energy System implemented Energy Storage System used}

\begin{tabular}{|c|c|c|c|c|c|c|c|c|c|c|c|c|c|}
\hline & TS & PV & WE & $\mathrm{Bf}$ & $\mathrm{He}$ & Gt WP & Other & PH & CA & F SC & RfB & LB $\quad H$ & Other \\
\hline ECO-Life & $X$ & $x$ & $X$ & & & $x$ & & & & & & & \\
\hline $\begin{array}{l}\text { HeatNET } \\
\text { NEW }\end{array}$ & & & & & & & $\begin{array}{l}\text { Cogeneration } \\
\text { Heat Pump, } \\
\text { Incineration. }\end{array}$ & & & & & & \\
\hline $\begin{array}{l}\text { Remo } \\
\text { urban }\end{array}$ & $X$ & $X$ & & & & $X$ & & $X$ & & & & $X$ & \\
\hline $\begin{array}{l}\text { Grow } \\
\text { Smarter }\end{array}$ & & $X$ & & & & & $\begin{array}{l}\text { Air-Water } \\
\text { Heat pumps }\end{array}$ & & & & & $X$ & \\
\hline $\begin{array}{l}\text { Smarter } \\
\text { Together } \\
1\end{array}$ & $x$ & $X$ & & & & & Biomass & & & & & & $\begin{array}{l}\text { Not } \\
\text { done } \\
\text { yet }\end{array}$ \\
\hline $\begin{array}{l}\text { Smarter } \\
\text { Together } \\
2\end{array}$ & & $X$ & & & & $X$ & & & & & & $x$ & \\
\hline $\begin{array}{l}\text { SmartEn } \\
\text { City }\end{array}$ & & & & & & & Biomass & & & & & & Pellets \\
\hline
\end{tabular}

Abbreviations: TS - Thermal Solar; PV - Photovoltaic; WE - Wind Energy; Bf - Biofuels; He Hydroelectric; Gt - Geothermal; WP - Wave power; PH - Pumped Hydro; CA - Compressed Air; F Flywheels; SC - Super-Capacitors; RfB - Redox flow Batteries; LT - Lithium Batteries; H - Hydrogen storage.

\subsubsection{Entities involved}

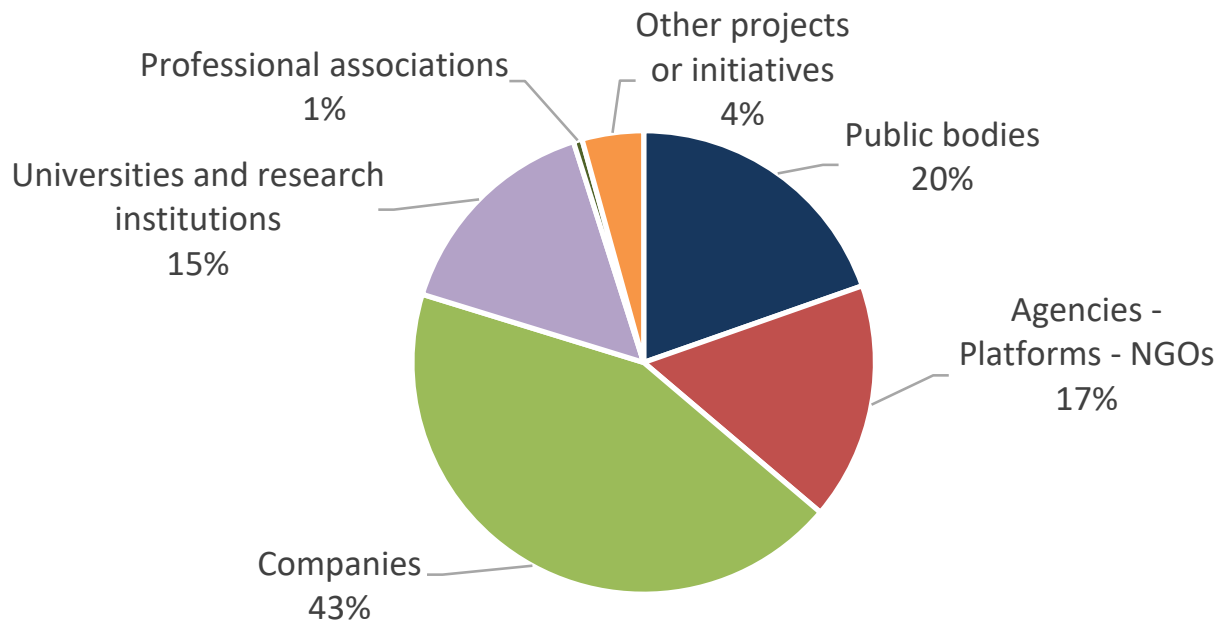

Fig. 4. 2 Profile of the partners in the European projects surveyed.

The composition of the consortia of these projects was varied and normally included public entities, research institutions, NGOs, agencies, companies, and others. The profile of the partners for the 16 projects analyzed in detail in our study is shown in 
Fig. 4. 2, and most of them were private companies. The presence of public entities, universities or research institutions and agencies/platforms/NGOs was similar.

The fact of working with data on the built environment (e.g., consumption, volumetry, density, energy management, etc), besides the necessary capacity to influence local policies for a real implementation of RE, makes the participation of public entities essential for this kind of project. After analyzing the set of 16 European projects related to the integration of $\mathrm{RE}$ in an urban environment, public administrations were found to be partners in each case and coordinating partners in four cases $(25 \%)$. This latter result could likely be explained by the very complexity of their bureaucratic functioning, which is also the reason it was exceedingly difficult to get information when required throughout the survey.

It should be noted that the public institutions involved in these projects were always at the local level, which makes it difficult to intervene in policies at the state level that might have a multiplier effect for this type of urban intervention as part of the necessary energy transition.

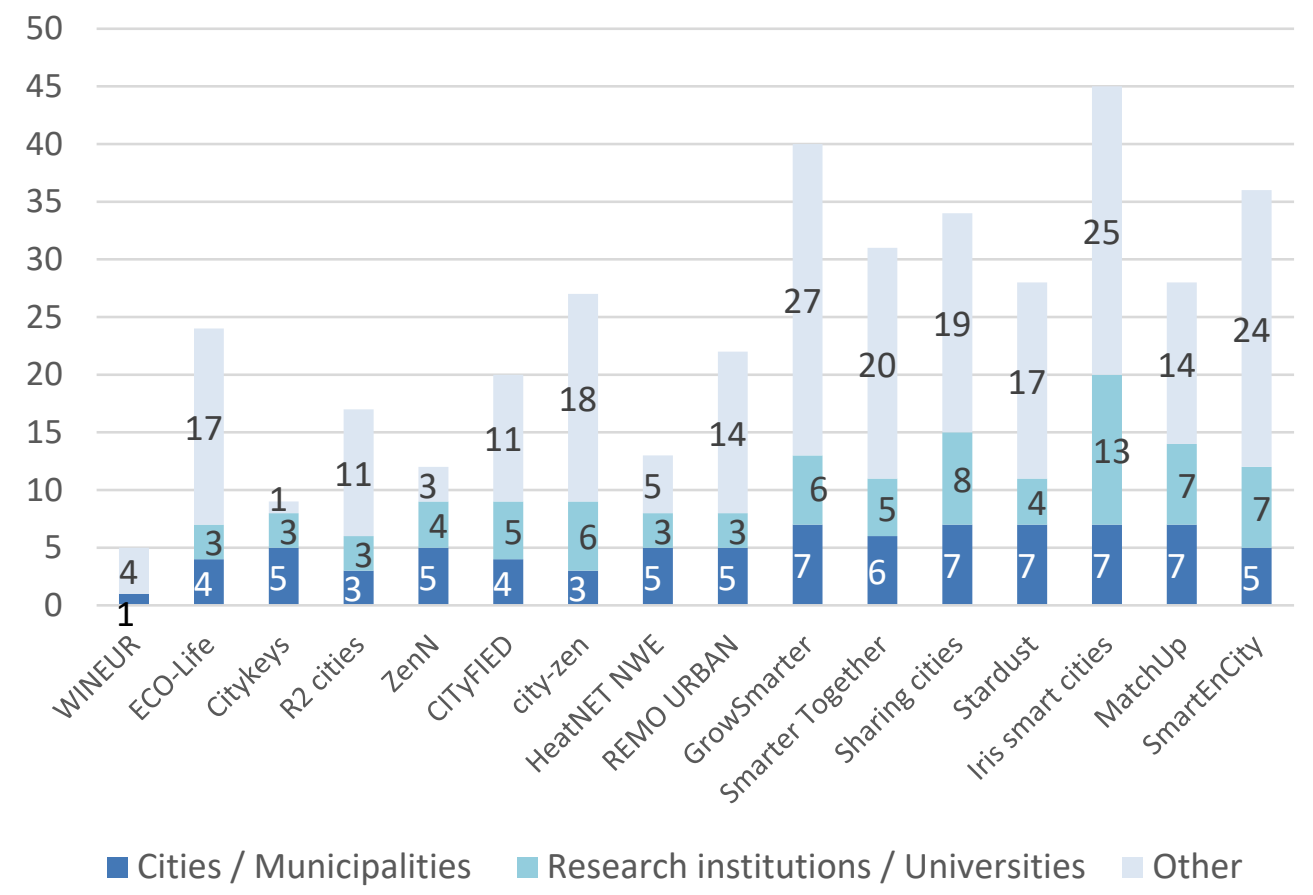

Fig. 4. 3 Type of partners in the 16 projects reviewed

As shown in Fig. 4. 3, the most common partners were the groups formed by private companies, agencies, NGOs, platforms, and others. They represented more than $50 \%$ of projects except for CityKeys (11\%), ZenN (25\%) and HeatNET NWE (38\%) projects, for which municipalities had a greater presence. However, public entities, referring 
to cities or municipalities, were between 15 and $25 \%$ of the consortium and were a lower percentage for City-zen (11\%) and a higher percentage for HeatNET NWE (38\%) and ZenN (42\%) and extraordinarily large for CityKeys at 56\%.

\subsection{Analysis and discussion}

\subsubsection{Renewable energies integration in the city}

According to the current revision, our first conclusion is that even though European projects have a clear interest in RE and SES, it is still from a theoretical point of view, seeking awareness, dissemination and cooperation. Therefore, to provide data from real demonstrations with efficient solutions applicable to other territories seems to be extremely complicated. According to the results shown in Table 4. 4, the most used renewable energy systems on an urban scale are thermal solar, photovoltaic, geothermal and biomass systems. Regarding energy storage, lithium batteries are commonly associated with solar energy systems and seem to be the most widespread solution. Overall, as shown in Table 4. 5, the number of European projects aimed at the real and effective implementation of renewable energy systems on an urban scale is relatively low, as only 16 out of 13989 reviewed projects (approximately $0.1 \%$ ) meet those criteria or standards. The number that considered integrated SES was even lower. Nevertheless, an increase in research to optimize this situation is still foreseeable, since according to prior literature, this type of project is of vital importance to effectively combat climate change, to improve global energy performance in cities, and to achieve more resilient cities (Amado et al., 2016; Curreli et al., 2016; Luo et al., 2015; Perea-Moreno et al., 2018). In this sense, terms such as "sustainable communities", "energy autonomy" or "energy self-sufficiency" were already used by Rae and Brandley (Rae and Bradley, 2012) to speak about sustainable development as a whole, including the technical challenge and the social and political consequences.

Table 4. 5 Data from the research on European-funded projects

\begin{tabular}{lcccc} 
& $\begin{array}{c}\text { REVISED } \\
\text { PROJECTS }\end{array}$ & $\begin{array}{c}\text { PROJECTS } \\
\text { IDENTIFIED WITH } \\
\text { REQUIREMENTS }\end{array}$ & PERCENTAGE & $\begin{array}{c}\text { PROJECTS } \\
\text { INCLUDED IN } \\
\text { THE STUDY }\end{array}$ \\
\hline INTERREG PROGRAM & 12333 & 38 & $0.3 \%$ & 1 \\
\hline LIFE PROJECTS & 78 & 0 & $0.0 \%$ & 0 \\
\hline CLIMATE KIC PROJECTS & 17 & 0 & $0.0 \%$ & 0 \\
\hline FP7 PROGRAM & 58 & 11 & $19.0 \%$ & 5 \\
\hline H2020 PROGRAM & 1503 & 17 & $1.1 \%$ & 10 \\
\hline \multicolumn{1}{r}{ TOTAL } & $\mathbf{1 3 9 8 9}$ & $\mathbf{6 6}$ & $\mathbf{0 . 5 \%}$ & $\mathbf{1 6}$
\end{tabular}

Concurring with the recommendations of the International Renewable Energy Agency's report (IRENA, 2017), there is currently a great interest in research that 
includes SES into urban energy systems (Amirante et al., 2017; Cebulla et al., 2018; Luo et al., 2015; Navarro et al., 2016, 2015). To this extent, Freitas et al. (Freitas et al., 2018) suggested that, from the point of view of the electricity grid, a higher storage capacity is needed to mitigate the costs of managing the load variance in the grid that it would entail, even though optimizing the tilt and orientation of the PV systems and aggregating the demand of several buildings, minimizes the storage needs. Additionally, some authors (Lovati et al., 2018) affirm in their research that "optimization performed from a set of electric storages shows a higher optimal capacity for the PV system and a higher flexibility for self-consumption, and consequently it has the potential to hugely expand the installation of urban photovoltaic". Unfortunately, our revision demonstrated that real implementation of SES at an urban scale in European projects is still scarce.

In the field of thermal energy, the scope of the reviewed projects seems greater, but they have not been finally included in our study unless they were combined with other renewable energy systems because they are usually buried and not have a significant visual impact (for a review of district heating and cooling systems, see the work of Werner (Werner, 2017)). In this regard, a new concept (i.e., "urban building energy models (UBEM)" using simulation methods) was used by Reinhart and Cerezo Davila (Reinhart and Cerezo, 2016) to refer to a key planning tool for utilities, municipalities, urban planners and even architects working on campus-level projects. It would be interesting for future research to include generation of electricity from renewable energies (mainly from BIPV systems) and storage systems in the UBEM simulations of consumption with the aim of creating a more complex analysis tool to assist in establishing more efficient and sustainable energy policy strategies for the city.

From a holistic point of view, the integration of energy systems must be a bespoke approach that considers the characteristics and needs of the system. In order to reduce risks and prevent duplication of effort, greater coordination at European level would be desirable by looking at successful pilot projects and ensuring access to the final results (Cambini et al., 2020).

\subsubsection{Temporal and policy frame}

Fig. 4.4 shows the evolution over time, since 2000, for the 63 projects that passed the second filter because of their relationship with the implementation of RE in the city. For each project, all the years of the program were marked. Three stages were clearly distinguishable with similarities to other studies in the literature in public expenditures on research and development for the renewable energy transition in Europe and are shown in this figure (Bointner et al., 2016).

Funding for new alternative energy sources to fossil fuels started in the early seventies during the Arab-Israeli War. At the end of the nineties, there was a new 
impulse for renewable energies (Bointner et al., 2016). Throughout these first years, the efforts were implemented in rural environments in the form of wind farms, photovoltaic plants or biomass plants, among others. A register of funded projects, that in the title showed an intention to implement renewable energies on an urban scale (passing the second filtering step), started in year 2000 . The first stage clearly comprises the 5-year time period (2000-2006) as shown in Fig. 4. 4. This stage is characterized by a small number of projects ( 3 or 4 ) that yearly passed the second filtering step, and by one project that passed the third filtering step (i.e., real implementation of RE on an urban scale).

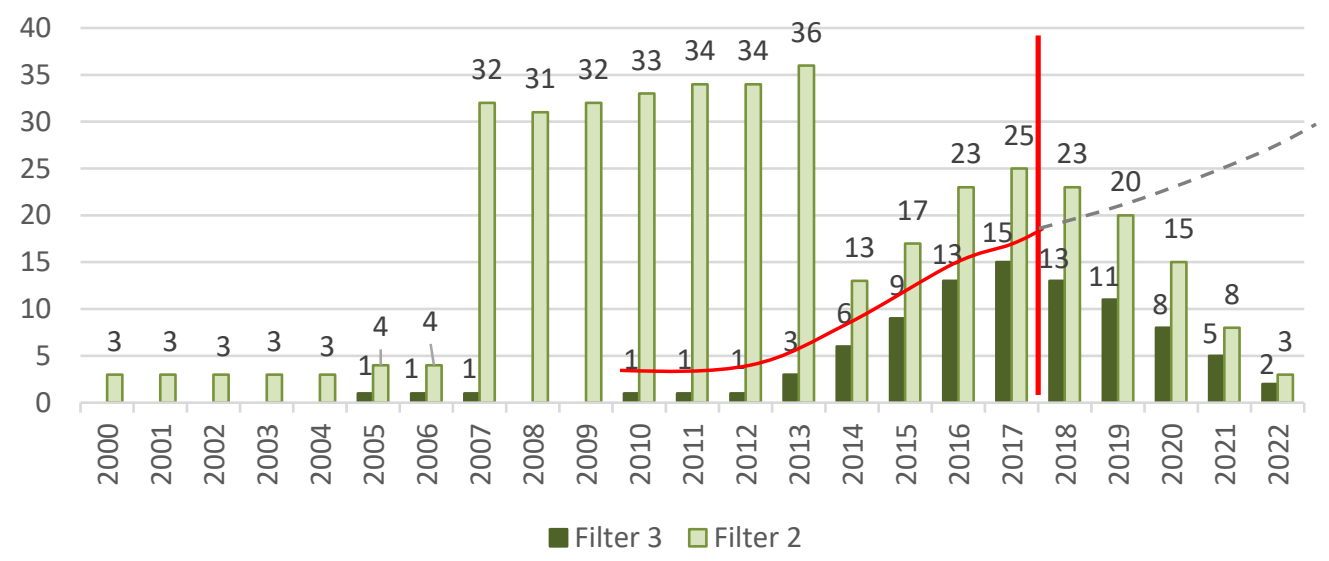

Fig. 4. 4 Number of projects per year applying filters 2 and 3

The second stage comprises years 2007-2013, which coincides with the economic crisis. As seen in Fig. 4. 4, the year 2007 marked a turning point for the European Union's climate and energy policy (EU, 2008), with the agreement to set targets on greenhouse gas emissions (a reduction of at least $20 \%$ by 2020 from the 1990 baseline), energy efficiency (savings of $20 \%$ by 2020 , expressed absolutely), and uptake of renewable energy (achievement of a $20 \%$ share of renewable energy in EU energy consumption by 2020). In the same year, the Strategic Energy Technology (SET) Plan (EU, 2007) was also published by the European Commission, which aimed to coordinate EU, national and private funding efforts in technology research and development to accelerate the EU's transformation to a low-carbon energy system (Moseley, 2017). In this stage, a significant number of projects in the Interreg Program passed the criteria established in the second filtering step, but most of them were posteriorly discarded through the third filtering step as these projects were exclusively framed as policy interventions and not from a practical or empirical perspective (Spurling et al., 2013) or because they affected individual buildings without urban integration.

Finally, continuous growth of potential projects with actions related to the real implementation of RE in urban environments (passing the third filtering step in our 
study) is shown in the third stage, from 2013 onwards. These projects were funded by the FP7 and H2020 programs. In 2014, the European Commission proposed ambitious energy efficiency targets by 2030 (EU, 2014b), such as a 40\% reduction in greenhouse gas emissions from the 1990 baseline or a $27 \%$ share of renewable energy consumption. At the end of 2016, a package of measures to position the European Union to lead the clean energy transition were presented by the European Commission (EU, 2016). One of the main goals was to put consumers at the heart of the Energy Union.

As the current revision was conducted at the end of 2018, all projects financed in the European calls from the same year onwards have not been considered, which explains why the trend in increased projects in the last period peaked in 2017. Accordingly, including the projects selected in subsequent calls, it would be expected that the above trend will continue.

\subsubsection{Geographical frame}

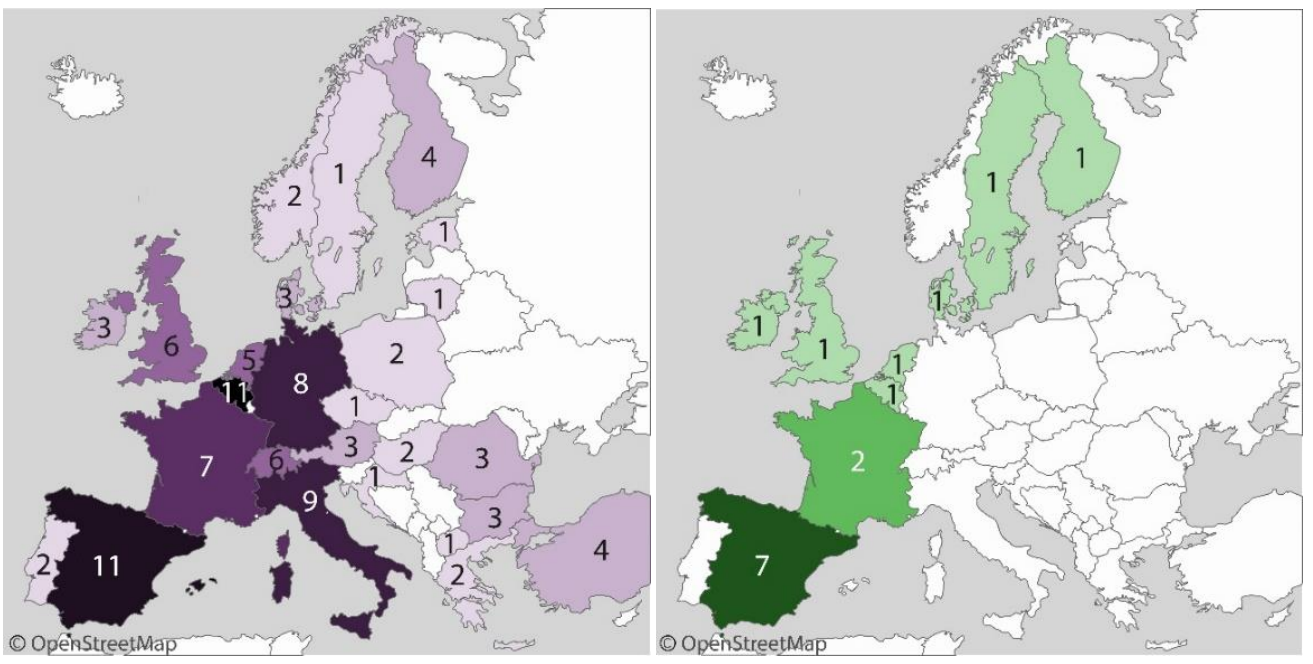

Fig. 4. 5 Geographical frame for the 16 European projects identified that include real implementation of RE on an urban scale: Left: Number in which the country is involved. Right: Number in which the country is coordinator.

The information collected from the websites of the 16 projects selected after applying the third filter allowed us to analyze the geographical frame of the real integration of renewable energies on an urban scale. As shown in Fig. 4. 5, Spain is the country that stands out most for its participation and its role as coordinator in the reviewed funded projects. Indeed, Belgium and Spain are the countries that have participated in the largest number of projects (69\%), followed by Italy (56\%) and Germany (50\%). This result certainly contrasts with the statistics corresponding to the number of countries coordinating these projects. Thus, although $44 \%$ of the projects were coordinated by Spain, only one project was coordinated by Belgium, 
and none by Italy or Germany. In both northern and eastern Europe, participation has been quite low, and many countries in eastern Europe have not participated in any of the revised projects.

It is interesting to note that, during this validation process, the reasons for working on this type of research project are very different in non-European countries and less developed environments (e.g., the lack of electricity supply in some underdeveloped areas). Additionally, for some countries with later and lesser implementation of solar energy (such as Spain), the focus of the scientific work has been on improving efficiency but reducing cost. However, other relevant issues, such as social acceptance, solidarity between neighbors (i.e., quantifying and sharing energy), and aesthetic perception, have not been considered priorities.

\subsubsection{Citizen involvement in the energy transition}

Implementation and integration of renewable energies at the urban level undoubtedly affects citizens, especially residents and people who work or circulate in the affected areas. However, in the analyzed projects, there were no local neighborhood associations or entities that would represent them, meaning that citizens were represented by the municipality itself, by agencies or by NGOs, with the exception of the SmartEnCity project in which the B42 Housing Association was a partner in the consortium. Therefore, the three dimensions of social acceptance (sociopolitical, communitarian and market) (Wüstenhagen et al., 2007), are generally not well-represented. This finding coincides with the conclusions of a previous study that stated that few studies on the implementation of renewable energies and energy storage included more than one of these three aspects in their respective analytical frameworks (Devine-Wright et al., 2017). Additionally, the necessary participation and involvement of residents to promote social acceptance of such projects has been highlighted in several studies (Flacke and de Boer, 2017; Langer et al., 2017; Strazzera and Statzu, 2017; Zoellner et al., 2008). Consequently, the social sector should be included in the consortia of these European-funded projects to improve social acceptance outcomes.

It should not be forgotten that energy transition requires a change in consciousness, habits and behaviors in society for these initiatives to be truly effective, which further justifies the involvement of citizens in the projects. Indeed, it has been stated that a full organizational cooperation between government, university and industry consistently improves consumer perceptions compared to a partial setup of pilot projects (Grimm et al., 2020). Notwithstanding, the inclusion of the social sector in this organizational cooperation seems to be indispensable. In this sense, we totally agree with the statement of a prior study regarding that "policy discussions should openly consider the role of perceptions of citizens in order to articulate sustainable and acceptable solutions" (Loureiro and Alló, 2020). 


\subsubsection{Aesthetic impact}

Social acceptance of RE projects might be influenced by several factors, such as the perception of a clean and renewable source, economic aspects, awareness, education, environmental concern, land use, and others. Currently, the aesthetic impact of the implemented systems has begun to be considered one of the most important factors in social tolerance. In fact, several studies including rural and urban environments have focused on aesthetic perception of SES deployment and its environmental impacts (Chen et al., 2013; Chiabrando et al., 2011; Kapetanakis et al., 2014; Mérida-Rodríguez et al., 2015; Sánchez-Pantoja et al., 2018a; Scognamiglio, 2016; Tolli et al., 2016; Torres-Sibille et al., 2009; von Möllendorff and Welsch, 2017). Furthermore, in urban environments, the visual appearance of the RES seems very important for the end user's preferences (Bao et al., 2017; Lu et al., 2018). Overall, taking into account the visual impact caused in the city by the implementation of renewable energy seems certainly imperative (Sánchez-Pantoja et al., 2018b).

Notwithstanding, a prior study suggested that neither specific strategies to assess the aesthetic impact of the implemented RES and SES nor images to evaluate this factor have been used (Sánchez-Pantoja et al., 2018b). In accordance with the methodological framework proposed in that study, "the aesthetic impact is broken down into three subimpacts: land use, which depends on the size and the quality of the landscape; Solar Energy System, which depends on visibility and degree of integration; and Glare, which depends on visibility." However, when BIPV systems are implemented, it does not make any sense considering land use. Instead, colors, patterns or shapes must be considered parameters that can influence the degree of integration.

Considering these three subimpacts and the clear influence of the visibility and degree of integration factors, several aspects should be considered for the design of different renewable energy systems. For example, not well-integrated visible solar systems might have a greater aesthetic impact as they affect, to a greater or lesser extent, the three subimpacts, which could be especially applicable for solar thermal systems that have a lower degree of integration with the environment because of their deposits. Instead, the aesthetic impact of PV technologies could be reduced by BIPV systems with an appropriate degree of integration (color, modulation, texture, etc.), and by avoiding glare. PV systems in urban public spaces (not in buildings) should be similarly well-integrated into urban furniture to eliminate the subimpact of land use, and avoiding glare. Biomass boilers or geothermal systems do not have aesthetic impact from visibility, degree of integration or glare because they are hidden systems with buried conduits. However, they impact real land use in the city.

An important factor for the aesthetic impact of renewable energy systems in a city would be visibility. It should be borne in mind that in rural environments, the visibility of windmills has been shown to affect the attitude of the observer (Butler and 
Wärnbäck, 2019; Klæboe and Sundfør, 2016). Additionally, "attitudes play an important role in addition to visual aesthetics in determining the acceptance of windmills and the resulting noise annoyance" (Klæboe and Sundfør, 2016). Similarly, the attitude towards a visible PV system might play an important role in determining acceptance and the resulting discomfort with glare, if any. Further studies specifically focused on the observer's attitude may be interesting future research and also consider the possible impact on cultural heritage (Butler and Wärnbäck, 2019).

Certain similarities are seen in the difficulties integrating the deposits of solar thermal systems aesthetically compared to implementing energy storage systems. However, the use of either renewable energies or energy storage systems, even when they are an essential part of energy and ecological transition, inevitably entails an aesthetic impact in the city that cannot be ignored. Similarly, researchers should not ignore that urban environments need available public space to implement innovative solutions that improve energy management from a collective point of view. Land use, visibility, and degree of integration seem to be determining factors in the aesthetic impact of these systems. Special attention should be given to location selection to minimize the impact on land use, reducing the size and visibility of the storage systems, and avoiding quality urban spaces. Aesthetic integration will require considering aspects, such as color, texture or shape, in the design process. In this case, it does not seem relevant to consider the subimpact of glare for the storage systems. Nevertheless, the usual trend when implementing renewable energies still seems to be hiding the installed systems inside the buildings or even burying them.

\subsubsection{Aesthetics in the H2020 Programme}

Currently, science policy incorporates public policy goals in an attempt to increase the transfer of science contributions to society as plausible solutions to relevant societal problems. Scientists have responded to this new funding strategy by casting their fields and topics as particularly promising. There can be little doubt that in addition to the window dressing triggered by targeted funding, such funding also has increased research on the intended topics (Gläser and Laudel, 2016). A deeper analysis of the interrelations between science policy and public policy goals was performed throughout the energy-related funding calls of the Horizon 2020 Program. Indeed, a large number of projects that passed the third filtering step in our study were included in this program.

Horizon 2020 focuses on three main pillars: (a) excellent science to strengthen the Union's world-class scientific excellence and make Union research and innovation systems more competitive, (b) fostering industrial leadership to speed the development of technologies that will support businesses and innovation, including for small companies, and (c) tackling societal challenges to respond to the priorities identified in the Europe 2020 strategy. In this line, energy is giving explicit attention under the societal challenge 10 'Secure, Clean and Efficient Energy'. Calls in this 
challenge have a total budget for non-nuclear research of almost $€ 6$ billion over 2014-2020. Each new biannual work package (2014-2015 WP, 2016-2017 WP and 2018-2020 WP) adopts the reinforcements and updates of the SET Plan (EU, 2007).

The keywords 'aesthetics' and 'visual' were included in the search conducted for the three work packages in the challenge. For the two last WPs (EU, 2018, 2016), the keyword 'visual' was related to visual comfort, considered a characteristic of indoor environmental quality, as is thermal comfort, acoustics or air quality. However, no results were found in the first WP (EU, 2015). During the last WP, transparent, 'visually nonintrusive' photovoltaic windows were expected technologies (although from TRL 3 to at least 5) in the LC-SC3-RES-2-2018 'Disruptive innovation in clean energy technologies' call (EU, 2018).

During the 2014-2015 WP, the word 'aesthetic' appeared in one call about renewable energies (LCE 3 - 2014/2015) that was related to photovoltaics integrated into the built environment, such as architectural considerations. During the next WP, the word 'aesthetic' appeared in one call, whereas aesthetics was one of the criteria of the 'Horizon prize for Integrated Photovoltaic System in European Protected Historic Urban districts'. In the 2018-2020 WP, the word 'aesthetic' appeared in one call related to BIPV (LC-SC3-RES-6-2018) and as novelty in one call (LC-SC3-EC-12018-2019-2020) to develop activities informing and motivating consumers to change old and inefficiently installed appliances to more efficient and clean energy heating and/or cooling solutions.

Changes in the SET Plan due to the 'Clean Energy for all Europeans' package measures (EU, 2016) reoriented the 2016-2017 Energy WP compared with its 20142015 predecessor with particular emphasis on enabling consumers to actively participate in the energy transition. The consequences of the aesthetic impact of renewable energies include consideration of visual comfort and awareness activities in changing the market.

These WPs align with a dominant understanding of consumers as rational individuals whose decisions and behaviors are determined by preset beliefs and attitudes. Within this paradigm, pro-environmental behavior-change focuses on decisionmaking and choice, and therefore, is often targeted through providing information and increasing awareness (Foulds and Christensen, 2016).

Consequently, forthcoming funding calls should consider technologies as products and core constituents of work and everyday life and not only as a means of intervention. It is indeed essential that technological change is not separated from social change (Foulds and Christensen, 2016). In this regard, technological change should not be separated from social change but rather the energy transition should rely on educating citizens as end-users of the product. To achieve effective and efficient energy savings, it seems extremely important to change consumption habits 
in the first place by making the population aware of the fact that they are real users who must accept the challenge of renewable energies for their own sake and that of future generations. To this extent, considering the opinions of citizens on the aesthetic impact of these technologies over the skyline could certainly prevent rejection by future users. Consequently, from our standpoint, the energy transition challenge might be seen as a phenomenon of human-environment interaction, and therefore, the research focus should change to facilitate the transfer of knowledge to the real world through the involvement of cities and their citizens.

\subsubsection{Limitations}

The revision of funded projects conducted in our study is innovative, groundbreaking and pioneering in the field of energy-related European programs. However, our research was limited to 5 specific and well-known funding programs in this area, and there could exist other initiatives or funding resources that have not been considered in our study. Although other regions such as USA, China, Japan or South Korea have a potential interest in the field of renewable energy integration, this research was focused narrowly on Europe and included almost 14000 projects. A broader analysis, contrasting results with other regions of interest, could certainly be the focus of further research.

The projects were previously filtered from several European Commission funding programs. European member states have their own $R+D$ expenditures programs. Other studies have found that the budget for renewable energy from European members states are about six times higher than those of the EC, but the trends over time are quite similar (Bointner et al., 2016). For example, in a country such as Germany that has not stood out for coordinating such projects (see Fig. 4. 5), the Environment Ministry manages several projects of seasonal storage, and technologies have been continuously researched and developed since 1993 (www.saisonalspeicher.de). Additionally, the Federal Ministry of Education and Research and the Federal Ministry of Economics and Energy allocate many resources to research and implementation projects promoting energy efficiency and energy transition (e.g., FutureSuN project, QUARREE 100 project).

The projects were consecutively filtered based on previously established keywords or topics according to their title and summary or consulting their web pages (i.e., first, second, and third filtering steps, respectively). It is possible that some projects did not pass any of the filters despite its consideration of the aesthetic impact. However, the answers to the questionnaire led us to the same conclusion about the scarcity concern that has existed, until now, on this subject. Moreover, the web pages of the funded projects consulted during the search were, in many cases, truly short or vague, especially for old projects. Consequently, sometimes it was difficult to apply the third filtering step. Furthermore, information about citizen 
participation, aesthetic impact, and photographs of the implementation were rarely found on these web pages.

Another limitation was the low quality of the electronic survey responses collected in the second phase of our study. It should be highlighted that many projects were still ongoing (not finished) at the time of this survey.

The scope of the current research was projects aimed to the deployment of renewable energies in cities. In this regard, solar technologies are the most funded facilities compared to other technologies such as geothermal and biomass with practically no aesthetic impact since they are buried or hidden inside the buildings.

\subsection{Conclusion and policy implications}

The main purpose of this work was to identify European-funded projects with a real implementation of renewable energies in cities and to analyze their concern for the aesthetic perception of society. To this aim, a systematic review of European projects was conducted including almost 14000 projects from the 5 programs considered most relevant to the promotion of renewable energies and climate change mitigation.

The current study shows that although European-funded projects have a strong relationship with the development and promotion of renewable energies, their involvement in real implementation of these technologies on an urban scale is still low. Since 2013, however, research has grown for potential projects with actions related to the real implementation of $\mathrm{RE}$ in urban environments.

Among projects identified with actual deployment of renewable energies in cities, the most implemented RES was clearly photovoltaic technology and, in some cases, solar thermal, biomass and/or geothermal projects. On the other hand, the use of energy storage systems was not widespread, with lithium batteries as the most commonly used type.

Since 2000, the evolution over time reflects three distinguished stages. The first stage, covering from 2000 to 2006, would be characterized by a small number of projects. The second stage, which comprises from 2007 to 2013, could be outlined with a significant number of projects thanks to the encouragement of European policies, although most of them were exclusively framed as policy interventions and not from a practical or empirical perspective. In the last stage, from 2013 onwards, a continuous growth of potential projects was observed.

In addition, the analysis of geographical frames for participations in these kinds of projects showed unequal involvement among European countries. While there has been greater participation of entities from Spain, Belgium, Italy, Germany and France, other countries from the north and east of Europe have lower participation. 
Furthermore, most of the European-funded projects included in this study were financed by the $\mathrm{H} 2020$ program. A deeper analysis of this program revealed that the aesthetic impact of the proposed technologies for promotion of renewable energies has never been considered a key topic. However, since 2014 the word 'aesthetic' has begun to appear as a specific call of each biannual work package related to architectural integration of photovoltaics.

From a policy perspective, the following would be the main implications.

First, greater coordination at European level should be encouraged. The fact that many of the partners in the European funding projects are companies, and the theoretical point of view of many of the projects, make it difficult to provide data from real demonstrations with efficient solutions applicable to other territories. Therefore, providing data from real demonstrations and promoting the replication of successful pilot projects would considerably reduce the efforts of European countries.

Second, the inclusion of the social sector in the consortia of European-funded projects must be rewarded, especially residents of the concerned area. A lack of local neighborhood associations, or entities that represent them, as part of the consortium of the European-funded projects has been revealed in this study. However, the participation and involvement of residents is necessary to promote social acceptance of the projects. Hence, the inclusion of the social sector in the organizational cooperation of the consortium partners, seems to be imperative to improve consumer perception.

Finally, we would like to highlight that forthcoming funding calls should start to consider the technologies as products and core constituents of work and everyday life and not only as a means of intervention to promote energies that are cleaner, renewable, and thus help us preserve the planet.

\section{AKNOWLEDGEMENTS}

The authors would like to thank the group of experts from the Energy Engineering Institute of the Polytechnic University of Valencia who helped us validate the questions included in the survey designed for collecting additional information in phase two of our study.

\section{REFERENCES}

Aas, $\varnothing$., Devine-Wright, P., Tangeland, T., Batel, S., Ruud, A., 2014. Public beliefs about highvoltage powerlines in Norway, Sweden and the United Kingdom: A comparative survey. Energy Res. Soc. Sci. 2, 30-37. https://doi.org/10/drwp 
Akinyele, D.O., Rayudu, R.K., 2014. Review of energy storage technologies for sustainable power networks. Sustain. Energy Technol. Assessments 8, 74-91. https://doi.org/10/drwr

Amado, M., Poggi, F., Amado, A.R., 2016. Energy efficient city: A model for urban planning. Sustain. Cities Soc. 26, 476-485. https://doi.org/10/ggfwtn

Amirante, R., Cassone, E., Distaso, E., Tamburrano, P., 2017. Overview on recent developments in energy storage: Mechanical, electrochemical and hydrogen technologies. Energy Convers. Manag. https://doi.org/10/drws

Bao, Q., Honda, T., El Ferik, S., Shaukat, M.M., Yang, M.C., 2017. Understanding the role of visual appeal in consumer preference for residential solar panels. Renew. Energy 113, 1569-1579. https://doi.org/10/drwt

Basecq, V., Michaux, G., Inard, C., Blondeau, P., 2013. Short-term storage systems of thermal energy for buildings: a review. Adv. Build. Energy Res. 7, 66-119. https://doi.org/10/drwv

Bointner, R., Pezzutto, S., Grilli, G., Sparber, W., 2016. Financing innovations for the renewable energy transition in Europe. Energies 9, 990. https://doi.org/10/f9db2q

Bonomo, P., Frontini, F., De Berardinis, P., Donsante, I., 2017. BIPV: building envelope solutions in a multi-criteria approach. A method for assessing life-cycle costs in the early design phase. Adv. Build. Energy Res. 11, 104-129. https://doi.org/10/drwz

Butler, A., Wärnbäck, A., 2019. Landscape and wind energy, Urban and Rural Reports.

Cambini, C., Congiu, R., Jamasb, T., Llorca, M., Soroush, G., 2020. Energy Systems Integration: Implications for Public Policy. Energy Policy 2020, 111609. https://doi.org/10/dzh2

Cebulla, F., Haas, J., Eichman, J., Nowak, W., Mancarella, P., 2018. How much electrical energy storage do we need? A synthesis for the U.S., Europe, and Germany. J. Clean. Prod. 181, 449-459. https://doi.org/10/gdbtvx

Chen, H.Q., Honda, T., Yang, M.C., 2013. Approaches for identifying consumer preferences for the design of technology products: a case study of residential solar panels. J. Mech. Des. 135, 061007. https://doi.org/10/gbdzzs

Chiabrando, R., Fabrizio, E., Garnero, G., 2011. On the applicability of the visual impact assessment OAISPP tool to photovoltaic plants. Renew. Sustain. Energy Rev. 15, 845850. https://doi.org/10/bdkjr8

Curreli, A., Serra-Coch, G., Isalgue, A., Crespo, I., Coch, H., 2016. Solar energy as a form giver for future cities. Energies 9. https://doi.org/10/f83cgv

D’Orazio, M., Di Perna, C., Di Giuseppe, E., 2013. Performance assessment of different roof integrated photovoltaic modules under Mediterranean Climate. Energy Procedia 42, 183-192. https://doi.org/10/drw6 
Devine-Wright, P., Batel, S., Aas, O., Sovacool, B., Labelle, M.C., Ruud, A., 2017. A conceptual framework for understanding the social acceptance of energy infrastructure: Insights from energy storage. Energy Policy 107, 27-31. https://doi.org/10/gbpts8

EU, 2018. Horizon 2020 Challenge 10. Secure, Clean and Efficient Energy: Work Programme 2018 - 2020.

EU, 2016. Clean Energy For All Europeans, $\operatorname{COM(2016)~} 860$.

EU, 2015. Horizon 2020 Challenge 10. Secure, Clean and Efficient Energy: Work Programme 2014 - 2015.

EU, 2014a. Establishing Horizon 2020 - The framework programme for research and innovation (2014-2020).

EU, 2014b. A policy framework for climate and energy in the period from 2020 to 2030, $\operatorname{COM}(2014)$ 015. OPOCE.

EU, 2010. EUROPE 2020 A strategy for smart, sustainable and inclusive growth.

EU, 2008. 2020 by 2020 Europe's climate change opportunity, COM(2008) 30.

EU, 2007. A European strategic energy technology plan (SET-plan) - "Towards a low carbon future." OPOCE.

EU, 2003. Directiva 2002/91/CE, Official Journal of the European Union.

Faiers, A., Neame, C., 2006. Consumer attitudes towards domestic solar power systems. Energy Policy 34, 1797-1806. https://doi.org/10/bf4bb7

Flacke, J., de Boer, C., 2017. An interactive planning support tool for addressing social acceptance of renewable energy projects in The Netherlands. ISPRS Int. J. GeoInformation 6, 313. https://doi.org/10/gcj53f

Florio, P., Munari, M.C., Schüler, A., Roecker, C., Scartezzini, J.L., 2018. Assessing visibility in multi-scale urban planning: A contribution to a method enhancing social acceptability of solar energy in cities. Sol. Energy 173, 97-109. https://doi.org/10/dsd7

Foulds, C., Christensen, T.H., 2016. Funding pathways to a low-carbon transition. Nat. Energy 1. https://doi.org/10/dsd8

Freitas, S., Reinhart, C., Brito, M.C., 2018. Minimizing storage needs for large scale photovoltaics in the urban environment. Sol. Energy 159, 375-389. https://doi.org/10/gcwz66

Gläser, J., Laudel, G., 2016. Governing science. How science policy shapes research content abstract. Eur. J. Sociol. 57, 117-168. https://doi.org/10/f8jhdc

Gleich, A. von, Gößling-Reisemann, S., Stührmann, S., Woizeschke, P., Lutz-Kunisch, B., 2010. Resilienz als Leitkonzept-vulnerabilität als analytische Kategorie. Theor. Grundlagen 
für erfolgreiche Klimaanpassungsstrategien. Bremen, Proj. Nord. 13-49.

Gößling-Reisemann, S., Wachsmuth, J., Stührmann, S., von Gleich, A., 2013. Climate change and structural vulnerability of a metropolitan energy system: The case of BremenOldenburg in Northwest Germany. J. Ind. Ecol. 17, 846-858. https://doi.org/10/f5knwr

Grimm, V., Kretschmer, S., Mehl, S., 2020. Green innovations: The organizational setup of pilot projects and its influence on consumer perceptions. Energy Policy 142, 1-14. https://doi.org/10/dzhz

Hemmerle, C., Hemmerle, C., 2016. Solar PV building skins: Structural requirements and environmental benefits. J. Facade Des. Eng. 5, 93-105. https://doi.org/10/drw9

Hille, S.L., Curtius, H.C., Wüstenhagen, R., 2018. Red is the new blue - The role of color, building integration and country-of-origin in homeowners' preferences for residential photovoltaics. Energy Build. 162, 21-31. https://doi.org/10/gc6tnk

IRENA, 2017. Electricity storage and renewables: Costs and markets to 2030, International Renewable Energy Agency. Abu Dhabi.

IRENA, 2015. Battery storage for renewables: Market status and technology outlook, International Renewable Energy Agency.

Kapetanakis, I.A., Kolokotsa, D., Maria, E.A., 2014. Parametric analysis and assessment of the photovoltaics' landscape integration: Technical and legal aspects. Renew. Energy 67, 207-214. https://doi.org/10/f52cws

Klæboe, R., Sundfør, H.B., 2016. Windmill noise annoyance, visual aesthetics, and attitudes towards renewable energy sources. Int. J. Environ. Res. Public Health 13, 1-19. https://doi.org/10/f8257d

Langer, K., Decker, T., Menrad, K., 2017. Public participation in wind energy projects located in Germany: Which form of participation is the key to acceptance? Renew. Energy 112, 63-73. https://doi.org/10/dsfc

Loulas, N.M., Karteris, M.M., Pilavachi, P.A., Papadopoulos, A.M., 2012. Photovoltaics in urban environment: A case study for typical apartment buildings in Greece. Renew. Energy 48, 453-463. https://doi.org/10/drxc

Loureiro, M.L., Alló, M., 2020. Sensing climate change and energy issues: Sentiment and emotion analysis with social media in the U.K. and Spain. Energy Policy 143. https://doi.org/10/dzh3

Lovati, M., Salvalai, G., Fratus, G., Maturi, L., Albatici, R., Moser, D., 2018. New method for the early design of BIPV with electric storage: a case study in northern Italy. Sustain. Cities Soc. https://doi.org/10/dsfd

Lu, M., Lin, A., Sun, J., 2018. The impact of photovoltaic applications on urban landscapes based on visual $Q$ methodology. Sustainability 10, 1-15. https://doi.org/10/gdr52n 
Luo, X., Wang, J., Dooner, M., Clarke, J., 2015. Overview of current development in electrical energy storage technologies and the application potential in power system operation. Appl. Energy 137, 511-536. https://doi.org/10/f6w3hg

Makrides, G., Zinsser, B., Norton, M., Georghiou, G.E., Schubert, M., Werner, J.H., 2010. Potential of photovoltaic systems in countries with high solar irradiation. Renew. Sustain. Energy Rev. 14, 754-762. https://doi.org/10/b8r4pt

Makrides, G., Zinsser, B., Phinikarides, A., Schubert, M., Georghiou, G.E., 2012. Temperature and thermal annealing effects on different photovoltaic technologies. Renew. Energy 43, 407-417. https://doi.org/10/fzs84s

Makrides, G., Zinsser, B., Schubert, M., Georghiou, G.E., 2013. Seasonal performance comparison of different photovoltaic technologies installed in Cyprus and Germany. Int. J. Sustain. Energy 32, 466-488. https://doi.org/10/drxd

Mérida-Rodríguez, M., Lobón-Martín, R., Perles-Roselló, M., 2015. The production of solar photovoltaic power and its landscape dimension, in: Renewable Energies and European Landscapes. Springer Netherlands, Dordrecht, pp. 255-277. https://doi.org/10/drxf

Moseley, P., 2017. EU support for innovation and market uptake in smart buildings under the Horizon 2020 framework programme. Buildings 7, 105. https://doi.org/10/dsfg

Naspetti, S., Mandolesi, S., Zanoli, R., 2016. Using visual Q sorting to determine the impact of photovoltaic applications on the landscape. Land use policy 57, 564-573. https://doi.org/10/drxg

Navarro, L., de Gracia, A., Colclough, S., Browne, M., McCormack, S.J., et al., 2016. Thermal energy storage in building integrated thermal systems: A review. Part 1. active storage systems. Renew. Energy. https://doi.org/10/drxh

Navarro, L., de Gracia, A., Niall, D., Castell, A., Browne, M., et al., 2015. Thermal energy storage in building integrated thermal systems: A review. Part 2. Integration as passive system. Renew. Energy. https://doi.org/10/drxj

Perea-Moreno, M.-A., Hernandez-Escobedo, Q., Perea-Moreno, A.-J., 2018. Renewable energy in urban areas: Worldwide research trends. Energies 11, 577. https://doi.org/10/gdr9rv

R2M, Onyx Solar, Flisom, BEAR-iD, Acciona, 2016. BIPV market and stakeholder analysis and needs Project report.

Rae, C., Bradley, F., 2012. Energy autonomy in sustainable communities-A review of key issues. Renew. Sustain. Energy Rev. 16, 6497-6506. https://doi.org/10/F4JWNQ

Reinhart, C.F., Cerezo, C., 2016. Urban building energy modeling - A review of a nascent field. Build. Environ. 97, 196-202. https://doi.org/10/F792M6

Rempel, A.R., Rempel, A.W., 2013. Rocks, clays, water, and salts: Highly durable, infinitely rechargeable, eminently controllable thermal batteries for buildings, Geosciences. 
https://doi.org/10/gcfpq9

Ruth, M., Özgün, O., Wachsmuth, J., Gößling-Reisemann, S., 2015. Dynamics of energy transitions under changing socioeconomic, technological and climate conditions in Northwest Germany. Ecol. Econ. 111, 29-47. https://doi.org/10/f65cpz

Sagani, A., Mihelis, J., Dedoussis, V., 2017. Techno-economic analysis and life-cycle environmental impacts of small-scale building-integrated PV systems in Greece. Energy Build. 139, 277-290. https://doi.org/10/f9ztx4

Sánchez-Pantoja, N., Vidal, R., Pastor, M.C., 2018a. Aesthetic perception of photovoltaic integration within new proposals for ecological architecture. Sustain. Cities Soc. 39, 203-214. https://doi.org/10/gdr37n

Sánchez-Pantoja, N., Vidal, R., Pastor, M.C., 2018b. Aesthetic impact of solar energy systems. Renew. Sustain. Energy Rev. 98, 227-238. https://doi.org/10/gfqh7s

Scognamiglio, A., 2016. "Photovoltaic landscapes": Design and assessment. A critical review for a new transdisciplinary design vision. Renew. Sustain. Energy Rev. 55, 629-661. https://doi.org/10/drxw

Spurling, N., Mcmeekin, A., Shove, E., Southerton, D., Welch, D., 2013. Interventions in practice : re-framing policy approaches to consumer behaviour.

Strazzera, E., Statzu, V., 2017. Fostering photovoltaic technologies in Mediterranean cities: Consumers' demand and social acceptance. Renew. Energy 102, 361-371. https://doi.org/10/f9hmhh

Tolli, M., Recanatesi, F., Piccinno, M., Leone, A., 2016. The assessment of aesthetic and perceptual aspects within environmental impact assessment of renewable energy projects in Italy. Environ. Impact Assess. Rev. 57, 10-17. https://doi.org/10/f8gp63

Torres-Sibille, A.C., Cloquell-Ballester, Vicente-A., Cloquell-Ballester, Víctor-A., Artacho, M.A., 2009. Aesthetic impact assessment of solar power plants: An objective and a subjective approach. Renew. Sustain. Energy Rev. 13, 986-999. https://doi.org/10/c4xh7r

Ürge-Vorsatz, D., Cabeza, L.F., Serrano, S., Barreneche, C., Petrichenko, K., 2015. Heating and cooling energy trends and drivers in buildings. Renew. Sustain. Energy Rev. 41, 85-98. https://doi.org/10/drxz

Vlad, A., Singh, N., Galande, C., Ajayan, P.M., 2015. Design considerations for unconventional electrochemical energy storage architectures. Adv. Energy Mater. https://doi.org/10/f3csc6

von Möllendorff, C., Welsch, H., 2017. Measuring renewable energy externalities: evidence from subjective well-being data. Land Econ. 93, 109-126. https://doi.org/10/dr8k

Wachsmuth, J., 2015. Cross-sectoral integration in regional adaptation to climate change via participatory scenario development. Clim. Change 132, 387-400. https://doi.org/10/f7r6g5 
Wachsmuth, J., Blohm, A., Gößling-Reisemann, S., Eickemeier, T., Ruth, M., et al., 2013. How will renewable power generation be affected by climate change? The case of a metropolitan region in Northwest Germany. Energy 58, 192-201. https://doi.org/10/f474rk

Werner, S., 2017. International review of district heating and cooling. Energy 137, 617-631. https://doi.org/10/gcjjnc

Wüstenhagen, R., Wolsink, M., Bürer, M.J., 2007. Social acceptance of renewable energy innovation: An introduction to the concept. Energy Policy 35, 2683-2691. https://doi.org/10/ct59cw

Xu, R., Wittkopf, S., Roeske, C., 2017. Quantitative evaluation of BIPV visual impact in building retrofits using saliency models. Energies 10, 668. https://doi.org/10/dr8m

Yang, R.J., Zou, P.X.W., 2016. Building integrated photovoltaics (BIPV): costs, benefits, risks, barriers and improvement strategy. Int. J. Constr. Manag. 16, 39-53. https://doi.org/10/drx5

Zhai, P., Williams, E., 2012. Analyzing consumer acceptance of photovoltaics (PV) using fuzzy logic model. Renew. Energy 41, 350-357. https://doi.org/10/djknkv

Zoellner, J., Schweizer-Ries, P., Wemheuer, C., 2008. Public acceptance of renewable energies: Results from case studies in Germany. Energy Policy 36, 4136-4141. https://doi.org/10/fbcz5t 


\section{CAPÍtulo 5. Discusión}

La investigación presentada en esta tesis doctoral abarca diferentes líneas de investigación significativas dentro del marco conceptual en el que se engloba, y que se corresponde con el impacto estético de los sistemas de energía solar (SES). A este respecto, la investigación desarrollada ha permitido: identificar los factores objetivos más influyentes en dicho ámbito de estudio, proponer la descomposición del impacto en sub-impactos facilitando así su análisis, estudiar la percepción social a través de la participación ciudadana y, finalmente, analizar la implicación de los proyectos europeos en los últimos años considerando su preocupación por el impacto estético. En este capítulo se discuten los resultados obtenidos en cada línea de trabajo y se argumenta la conexión que existe entre dichas líneas, así como la relación que guardan con otras investigaciones previas. Para ello, se dedica un apartado a cada uno de los estudios presentados en los capítulos 2, 3 y 4 (que se corresponden textualmente con las 3 publicaciones de revistas científicas indexadas que conforman la presente tesis doctoral, sin ninguna modificación), destacando en cada caso su conexión con los trabajos anteriores.

Una vez discutidos los resultados más relevantes, se analizan las principales limitaciones de la tesis y se proponen diversas líneas de investigación futuras que podrían llevarse a cabo partiendo de los resultados aquí expuestos. Así, el trabajo de esta tesis pretende servir de base para trabajos futuros en el ámbito de la percepción estética de los sistemas de energía solar. Por último, en el apartado 5.6 se consideran las posibles repercusiones que puede llegar a tener la investigación desarrollada en esta tesis doctoral, tanto para la sociedad en general como para el proceso de implantación de los sistemas de energía solar integrados en la trama urbana. Cabe resaltar que es un proceso en el que tanto administraciones públicas, como sectores productivos y técnicos proyectistas deberían trabajar conjuntamente para mejorar la aceptación estética de los ciudadanos.

\subsection{Impacto estético de los sistemas de energía solar}

En el segundo capítulo de la tesis se muestra la investigación realizada para estudiar el impacto estético de las instalaciones de energía solar desde un punto de vista objetivo (Sánchez-Pantoja et al., 2018a). Una profunda revisión de la literatura existente respecto a los factores objetivos influyentes mostró una falta de unanimidad cuando se aplican dichos factores en la evaluación de diferentes niveles del impacto y, por lo tanto, una evidente dificultad para compararlos. En consecuencia, los resultados de este trabajo suponen una aportación relevante para el marco conceptual del impacto estético de los sistemas de energía solar.

A continuación se discuten los resultados principales del capítulo 2, en los que la visibilidad y el grado de integración de las instalaciones se establecen como los factores más influyentes. Esta conclusión se corrobora con estudios posteriores y se 
verá también reforzado en la discusión de los resultados del capítulo 3 . En este apartado, también se incluyen dos secciones en las que se analiza la aplicación del marco metodológico cualitativo propuesto a la integración de los sistemas BIPV en los edificios, así como a la localización y la evaluación del impacto ambiental.

\subsubsection{Discusión de los resultados principales}

En este trabajo se propone un marco metodológico cualitativo (Fig. 5. 1) en el que el impacto estético se descompone en 3 sub-impactos: el del uso del suelo, el del propio sistema de energía solar (SES) y el del deslumbramiento. Cabe recordar que el uso del suelo no solo hace referencia a la ocupación, sino también a la alteración en la calidad del paisaje como consecuencia de haber instalado el sistema de energía solar. A su vez, estos sub-impactos dependen fundamentalmente de dos factores: la visibilidad y el grado de integración. Dentro de este marco, el factor destacado como más importante y que siempre debe tenerse en cuenta cuando se evalúe el impacto estético de un sistema de energía solar es la visibilidad. Sin embargo, se ha demostrado la importancia de matizar el concepto de visibilidad para cada caso. Por ejemplo, la visibilidad se referiría al tamaño cuando se evalúa el sub-impacto estético del uso del suelo (Koellner et al., 2013; Suuronen et al., 2017); al porcentaje visible de la instalación cuando se evalúa el sub-impacto estético del SES (Chiabrando et al., 2011; Kapetanakis et al., 2014; Torres-Sibille et al., 2009); y a la observación del rayo de luz deslumbrante para evaluar el sub-impacto estético del deslumbramiento (Ho et al., 2015; Rose and Wollert, 2015).

1a) Land use

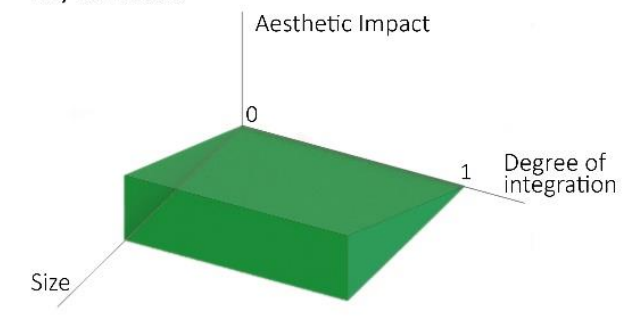

1c) Glare

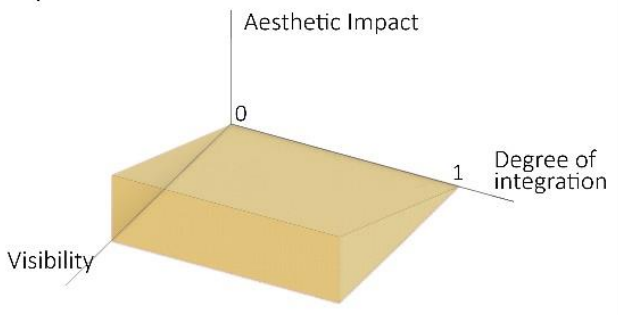

1b) SES

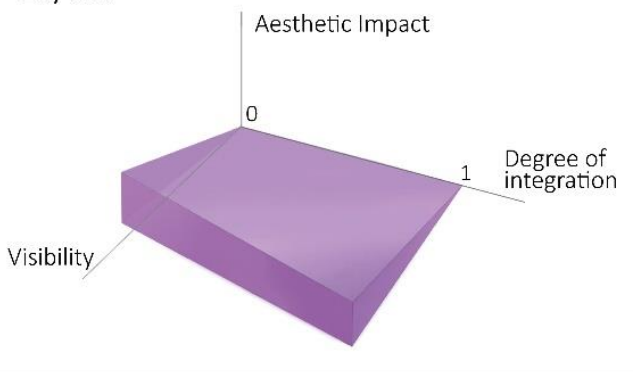

1d) Overall aesthetic impact

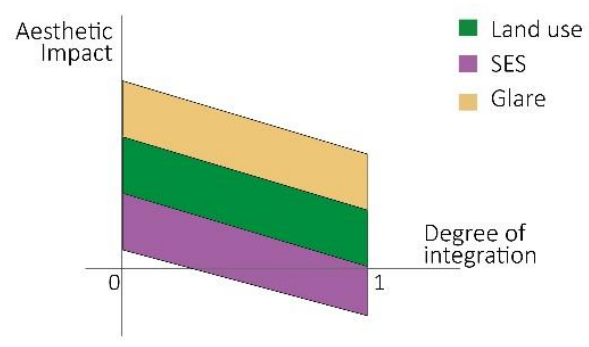

Fig. 5. 1 Representación gráfica del marco metodológico cualitativo. 1a) Sub-impacto Uso del suelo; 1b) Sub-impacto SES; 1c) Sub-impacto deslumbramiento; y 1c) Impacto estético total. 
Después de la visibilidad, el factor objetivo más relevante resultó ser el grado de integración, lo que refuerza la teoría de Bishop (Bishop et al., 1990; Bishop, 1997) que concluía que el mayor interés en los impactos visuales reside en la relación entre el objeto y su entorno. Sin embargo, este factor puede verse influido a su vez por numerosos factores de los calificados como "simples e independientes" en el capítulo 2, como el contraste del color, la textura o la fractalidad. Por ejemplo, los contrastes harmónicos del color y las texturas menos evidentes mejorarían la integración (Bao et al., 2017; Chen et al., 2013; García et al., 2003; Scognamiglio, 2016). Además, aunque el conjunto de estos factores simples (color, forma, textura, fractalidad, etc.) no modifican la cantidad de área visible de la instalación, coincidimos con otros estudios afirmando que sí pueden influir en que el impacto sea mayor o menor dependiendo de la continuidad visual y del contraste que produzcan (García et al., 2006; Munari and Roecker, 2011). El grado de integración estará relacionado con el entorno natural en el caso de huertos solares y con elementos de construcción arquitectónica en los entornos urbanos. En este sentido, el caso concreto del factor de la fractalidad deberá considerarse cuando se analice la percepción en entornos naturales (Chiabrando et al., 2011; Hagerhall et al., 2004; Kapetanakis et al., 2014; Stamps, 2002; Torres-Sibille et al., 2009).

Recientemente, el concepto de "prominencia visual" ("visual saliency" en inglés), que hace referencia a la probabilidad que tiene una determinada región de una imagen para atraer la atención visual humana en comparación con su entorno, enfatiza la relevancia que tiene el hecho de ver las imágenes por ordenador, abriendo nuevas e interesantes formas de medir o considerar parámetros (Xu et al., 2017). Sin embargo, el principal problema que encontramos cuando analizamos el grado de integración es la falta de un método claro y sin ambigüedades que nos permita medirlo. Por ejemplo, la integración fotovoltaica en un entorno natural difiere mucho de la que tiene lugar en la envolvente de un edificio. En el caso del edificio, no solo se ven involucrados factores objetivos simples, sino que deberían considerarse también otras particularidades más complejas como la habilidad del observador para percibir que el elemento que compone la fachada tiene además otras funciones adicionales, o la propia percepción subjetiva del que observa. Esto añade cierta incertidumbre a los resultados en los que se tiene en cuenta el factor del grado de integración. En relación a este tema, resultan de gran interés aquellos estudios en los que el grado de integración es objeto de un análisis profundo para establecer criterios claros a aplicar en su medición, considerando además la amplia variedad de sistemas fotovoltaicos existentes y sus posibles formas de colocarse en el edificio (Munari and Roecker, 2019, 2015, 2011). Sin embargo, cabe destacar que cuando se evalúa el grado de integración debe considerarse, además del punto de vista de los técnicos diseñadores, la percepción que tienen los ciudadanos.

La revisión de la literatura relacionada con los sistemas de energía solar muestra muy pocos estudios en los que se haya valorado la percepción estética, además de muy poca variedad de métodos. La literatura sobre percepción y emociones en otros 
ámbitos presenta alternativas interesantes basadas en difusión ("fuzzy" en inglés), mapas cognitivos, agentes inteligentes, etc. (Kowalczuk and Czubenko, 2016). Obviamente, al igual que los resultados emergentes de la estética computacional, estos modelos ofrecen nuevas posibilidades de investigación para la evaluación estética de los sistemas de energía solar.

Con los resultados aportados en el capítulo 2 se ha cumplido el objetivo de definir los factores objetivos más influyentes en el impacto estético de los sistemas de energía solar, siendo éstos la visibilidad y el grado de integración, así como el objetivo de proponer un marco metodológico cualitativo que sirva de base a futuras investigaciones. De esta forma, aunque sin una hipótesis previa definida, se da respuesta a la falta de consenso de la literatura y se ofrecen herramientas para la sistematización en la evaluación de impacto estético de la integración de energías renovables.

Como confirmación de los resultados hallados, encontramos en la literatura una publicación posterior a los artículos incluidos en los capítulos 2 y 3 de esta tesis que coincide con el marco metodológico cualitativo aquí propuesto en cuanto a los factores visuales considerados más relevantes (Bevk and Golobič, 2020). En dicho estudio, que se centra en instalaciones fotovoltaicas situadas en entornos rurales, se recogen datos de los propios participantes sobre la percepción de ciertos paisajes en los que hay instalaciones fotovoltaicas. Es un estudio puramente cualitativo en el que se pide a los participantes que hagan fotos y comentarios sobre los paisajes que visitan, sin mencionarles las instalaciones fotovoltaicas. De esta forma, se evita centrar la atención del participante en la instalación como objeto de estudio. Las categorías visuales en los resultados de dicho estudio se corresponden con las identificadas en esta tesis. Así, el grado de integración se posiciona como el más relevante, seguido de la visibilidad. Por otro lado, los participantes mostraron preocupación por el uso del suelo, así como varios aspectos relacionados con las características de la instalación. Sin embargo, el deslumbramiento raramente fue mencionado, quizás porque el deslumbramiento genera un impacto intermitente que, como se ha mencionado anteriormente, depende de la observabilidad del rayo que lo produce. En entornos rurales, debido al grado de inclinación de los paneles, es más habitual encontrar problemas de deslumbramiento para los pilotos de los aviones que para las personas presentes en el lugar. No así en las ciudades, donde puede afectar a viandantes, pero también a personas en edificios próximos.

\subsubsection{Aplicación a la integración de sistemas BIPV en los edificios}

En el ámbito europeo, la opinión pública recibe generalmente como positiva la implantación de los sistemas de energía renovable, aunque algunos proyectos extensivos de huertos solares pueden provocar resistencia a la aceptación o descontento local (Scognamiglio, 2016). Sin embargo, algunos estudios que han evaluado la percepción estética en relación a la integración fotovoltaica han 
mostrado resultados muy favorables (Lu et al., 2018; Naspetti et al., 2016; SánchezPantoja et al., 2018b; Strazzera and Statzu, 2017).

Las diferencias entre la integración de los sistemas de energías renovables en edificios y en el medio rural son evidentes. El cambio de escala supone un nivel de complejidad distinto y que se deban tener en cuenta otros parámetros de diseño (Scognamiglio, 2016). Además, los objetivos del diseño arquitectónico a veces pueden entrar en conflicto con el buen funcionamiento energético, por lo que cierto grado de adaptación podría ser recomendable. Como es bien conocido, la integración de los sistemas fotovoltaicos en la envolvente del edificio se puede hacer mediante elementos que recubran la cubierta o la fachada, pero también a través de las propias ventanas por medio de vidrios fotovoltaicos semitransparentes y concentradores solares luminiscentes (CSL). Con las ventanas fotovoltaicas semitransparentes se pueden reducir las ganancias de temperatura debidas a la incidencia solar, a la vez que se genera energía (Bizzarri et al., 2011; Cannavale et al., 2017; Kapsis and Athienitis, 2015; Skandalos et al., 2018). Y esto podemos conseguirlo con una amplia variedad de tecnologías fotovoltaicas, desde las células basadas en silicio (dispuestas de tal manera que permiten que la luz pase a través del espacio libre entre las células opacas) hasta las películas delgadas "transparentes", como el a-Si (silicio amorfo), el CIGS (cobre, indio, galio y selenio), los dispositivos fotovoltaicos orgánicos (OPV), las células solares sensibilizadas por colorante y las células solares basadas en perovskita. Concretamente, los CSL ofrecen una gran adaptabilidad a las necesidades de los arquitectos en el sentido de que se pueden fabricar en variedad de colores, formas y transparencias, además de que pueden ser flexibles y ligeros (Debije and Verbunt, 2012). Por ejemplo, con la aplicación de esta tecnología, como mínimo en un $25 \%$ de la superficie de ventana en oficinas, se puede proveer de energía eléctrica adicional, generada en la propia envolvente del edificio, con un mínimo impacto en los niveles de confort visual de sus ocupantes y una influencia mínima en el rendimiento de los dispositivos (Vossen et al., 2016). Sin embargo, debemos tener en cuenta que la falta de conocimientos específicos por parte de los arquitectos, así como la escasa información técnica disponible de estas tecnologías, dificultan que se extienda el uso de este tipo de soluciones integradas para la generación de energía en el propio edificio. Un ejemplo de ello lo encontramos en el factor solar (valor g) de los vidrios fotovoltaicos semitransparentes, necesario para justificar el comportamiento energético del edificio en proyecto y que raramente está disponible en la ficha técnica del producto (Olivieri et al., 2015).

La Fig. 5.2 muestra un esquema de los parámetros más importantes a considerar si aplicáramos el nuevo marco metodológico propuesto (Fig. 5. 1) para evaluar los sistemas BIPV. El primer sub-impacto "uso del suelo" podríamos desestimarlo puesto que no hay una alteración en la calidad del paisaje debida a un cambio de uso de suelo específico para la instalación. Es la propia envolvente del edificio, la que en su superficie alberga una función adicional a la suya de proteger el espacio interior con 
un determinado acabado estético. El sub-impacto con más peso sería el causado por el propio SES, influenciado por la visibilidad de la instalación, pero especialmente por el grado de integración. Debemos tener en cuenta que, puesto que el espacio urbano es el entorno habitual diario de la mayoría de la población, la percepción subjetiva de los ciudadanos también será importante. El apego y la identidad con la ciudad podría llevar al rechazo de una nueva instalación si se percibe que la estética urbana ha empeorado. Sin embargo, algunos estudios han demostrado que sistemas BIPV bien integrados, percibidos como una mejora del entorno urbano, son apreciados por la gente del centro de la ciudad y con mayor apego (Strazzera and Statzu, 2017). Sería interesante tener esto en cuenta si consideramos el impacto que puedan tener estos sistemas en la visibilidad de puntos de referencia o hitos urbanos.

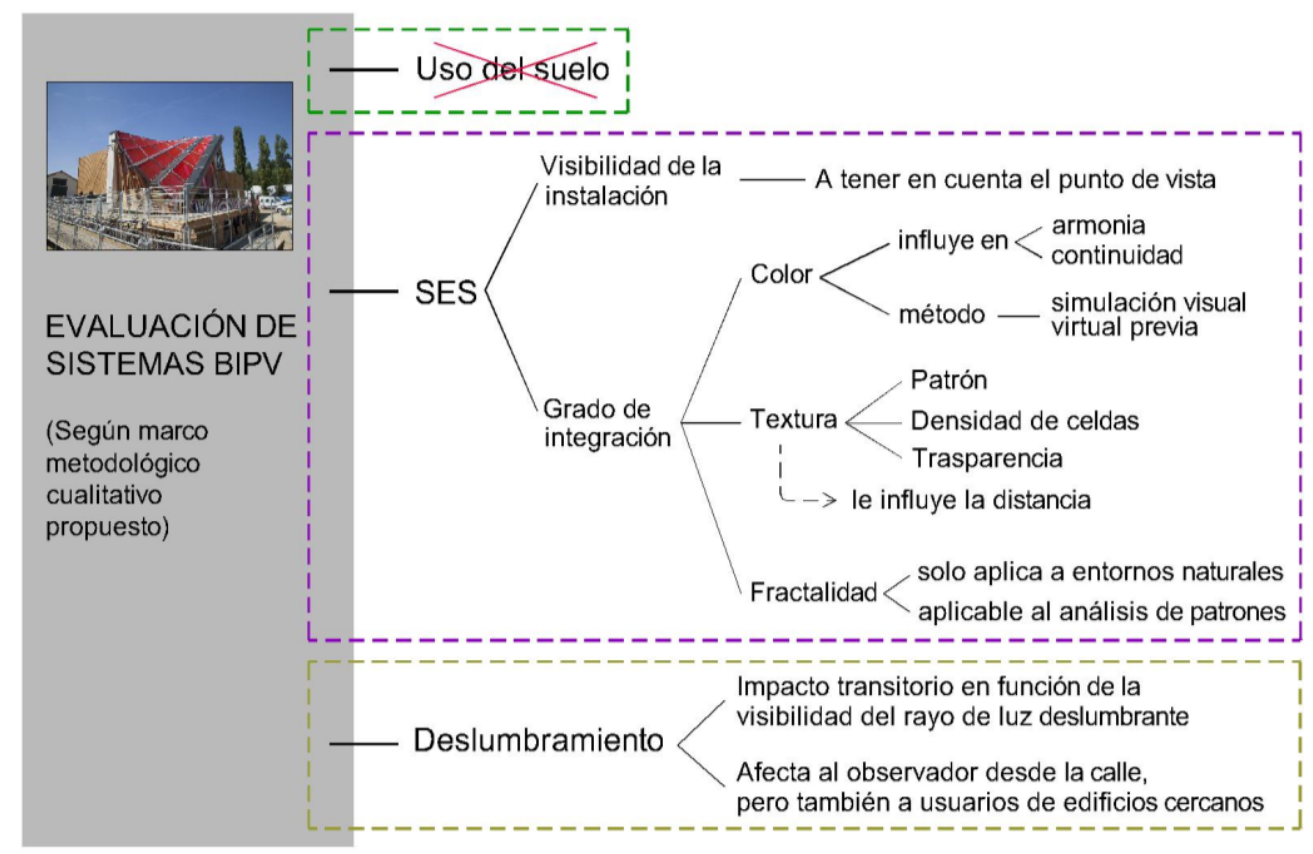

Fig. 5. 2 Esquema de los parámetros más importantes a tener en cuenta para la evaluación de los sistemas BIPV en el entorno urbano, según el marco metodológico cualitativo propuesto.

Respecto al factor de la visibilidad, es de gran importancia en escenarios urbanos el punto de vista desde el que se toman las imágenes para llevar a cabo el estudio (Kapetanakis et al., 2014). Debe prestarse especial atención a parámetros como la perspectiva, la distancia o la altura, con la finalidad de obtener fotografías que reproduzcan fielmente lo que ven los ciudadanos. De esta forma, las imágenes tomadas desde el cielo o utilizando drones desde ángulos o alturas que son imposibles en los movimientos normales de los ciudadanos no serían válidos, y los resultados previos obtenidos con fotografías aéreas de instalaciones fotovoltaicas podrían ser cuestionados (por ejemplo, Naspetti et al., 2016). 
De forma similar, el grado de integración es obviamente un factor muy influyente para determinar el impacto de los sistemas BIPV. Sin embargo, ya hemos destacado la falta de consenso sobre cómo debería valorarse este factor y la necesidad de establecer un criterio inequívoco para evaluarlo. La buena integración y el mejor ocultamiento de la instalación están más valorados por parte del observador. Pero no debemos olvidar que parámetros como el tipo de formación profesional del encuestado, si están relacionados por ejemplo con el ámbito de la arquitectura, ha influido en la percepción estética de los sistemas fotovoltaicos. Al mismo tiempo, los resultados de los ciudadanos que no tenían esta relación muestran mucha más heterogeneidad en sus preferencias (Gifford et al., 2000; Naspetti et al., 2016).

Continuando con los sistemas BIPV, siempre que la instalación esté a la vista, el grado de integración se convierte en el factor más relevante. Una buena integración no solo dependerá de la habilidad para combinar la instalación con otros elementos constructivos, sino que se verá influenciada por características físicas que ayudan a armonizar estéticamente el sistema con el edificio, como podrían ser el color o la textura de la superficie.

La literatura revisada respalda la importancia del parámetro del color, que definitivamente debería tenerse en cuenta en investigaciones futuras. La atención a la armonía y a la continuidad del color en fases de diseño será esencial si los arquitectos e ingenieros quieren conseguir una buena integración estética con buena aceptación por parte de la sociedad. Con esta finalidad, sería interesante trabajar con una buena simulación visual previa de la instalación, principalmente en cuanto al color y la forma (Chiabrando et al., 2011), pero considerando siempre el punto de vista del ciudadano. De acuerdo con la literatura, para analizar la relación y la armonía con el entorno, la mejor forma de trabajar con el factor del color sería identificarlo basándose en los tres parámetros: tono, saturación y brillo. Es más, la correspondencia del color digital en la imagen con el color verdadero se considera crítica (García et al., 2003).

La textura también es un factor interesante que, en el caso de los edificios, viene dado por los materiales utilizados en la envolvente. Dado que la integración fotovoltaica se hace en la envolvente del edificio, este factor resulta relevante puesto que la selección de los materiales de un edificio influye para conseguir su integración con el entorno (García et al., 2006). Atendiendo a la terminología utilizada en la literatura revisada, cuando evaluamos sistemas BIPV parece más correcto utilizar el término "patrón" ("pattern" en inglés), entre otros conceptos como la densidad de celdas o la transparencia (Bao et al., 2017; Cerón et al., 2013; Scognamiglio, 2016). Adicionalmente, cuando se tomen fotografías para el estudio, debería prestarse especial atención a la distancia, puesto que la influencia de la textura es mayor en un escenario urbano, donde la distancia del observador es más corta que en un entorno rural (García et al., 2006). Por ejemplo, una misma textura 
que resulta muy perceptible desde el nivel de calle en las plantas bajas del edificio podría pasar totalmente desapercibida en las plantas más altas.

En cuanto a la fractalidad, cabe destacar que todos los estudios revisados que consideraban este factor están de alguna forma relacionados con la naturaleza. Además, suelen tener como objetivo comparar la dimensión fractal entre el paisaje medioambiental y el construido, o bien evaluar el impacto estético en un ambiente natural. Esto se ve reforzado por el concepto de que la dimensión fractal es una dimensión percibida que se puede utilizar para determinar la estética de un patrón y, por tanto, para identificar las cualidades naturales y la naturalidad del patrón (Hagerhall et al., 2004). Hay estudios que establecen que el análisis fractal es uno de los pocos métodos que nos permite comparar cuantitativamente las propiedades geométricas de la naturaleza con las de la arquitectura (Vaughan and Ostwald, 2017). En consecuencia, deberíamos pensar que al analizar el impacto estético y el agrado de la integración de la fotovoltaica en edificios -en un contexto en el que no interviene la naturaleza-, considerar la dimensión fractal como un factor influyente podría no ser lo más apropiado. Pero cuando se considere concretamente la distribución de la instalación o la forma de las celdas, este factor podría relacionarse con el análisis de patrones.

El sub-impacto SES detallado en los anteriores párrafos y en la Fig. 5.2 muestra importantes similitudes con los resultados de una investigación que se ha llevado a cabo durante la última década (Munari and Roecker, 2019, 2015, 2011) a la hora de considerar los factores más relevantes en la percepción de los sistemas solares integrados en los edificios. Cabe mencionar que no se tenía conocimiento de estos estudios cuando se publicaron los artículos correspondientes a los capítulos 2 y 3 de esta tesis doctoral. Dicha investigación desarrolla un método cualitativo para controlar el impacto visual de los SES urbanos Ilamado LESO-QSV que evalúa la visibilidad, la sensibilidad y la calidad arquitectónica de las instalaciones. En este método, la integración arquitectónica pone en valor su relación con la calidad del entorno construido en el que se integra el sistema de energía solar. Para ello, de forma similar al marco propuesto en esta tesis doctoral, la evaluación de la integración arquitectónica tiene en consideración parámetros geométricos (el tamaño y la posición), de los materiales del sistema (parte visible, textura de la superficie y colores) y del patrón de los módulos (forma de los módulos y juntas). Estos parámetros son fácilmente identificables con los que en esta tesis doctoral se han calificado como factores simples o dependientes. Por otro lado, este método desarrolla un nuevo concepto llamado criticidad arquitectónica que viene definido por dos factores: la visibilidad de la superficie y la sensibilidad arquitectónica del entorno urbano en el que se integra (por ejemplo, un entorno industrial es considerado de sensibilidad baja, y un edificio singular es considerado de sensibilidad alta). La aplicación del método LESO-QSV a casos concretos se ha realizado en un proyecto de la Agencia Internacional de la Energía, en el que se han analizado 34 
casos de sistemas solares existentes, incluyendo entornos urbanos y rurales, así como sistemas térmicos y fotovoltaicos (Lobaccaro et al., 2019).

Finalmente, el tercer sub-impacto, el "deslumbramiento", también debería ser considerado en la evaluación del impacto de los sistemas BIPV. El deslumbramiento es un factor muy peculiar y probablemente menos común en entornos urbanos que en rurales debido al tipo de materiales que se utilizan. Sin embargo, debe tenerse en cuenta porque si hay deslumbramiento, lo cual es normalmente transitorio, puede ser muy molesto. Las herramientas informáticas actuales hacen posible el cálculo y la cuantificación de este factor de forma precisa (Ho et al., 2015; Rose and Wollert, 2015). En el caso de evaluar sistemas BIPV en entornos urbanos, donde este problema no solo afecta a las personas de la calle, sino que puede ser molesto incluso para los usuarios de los edificios cercanos a través de sus ventanas, el cálculo debería extenderse a las fachadas de los edificios que se puedan ver afectados. Cabe resaltar que en la literatura relacionada con sistemas fotovoltaicos semitransparentes y condensadores solares luminiscentes, el deslumbramiento se considera únicamente como un factor de confort visual para los ocupantes del edificio (Cannavale et al., 2017; Skandalos et al., 2018; Vossen et al., 2016).

Resumiendo, el impacto estético de los sistemas BIPV debería descomponerse en dos sub-impactos: SES (más importante) y deslumbramiento. Respecto al impacto SES, la visibilidad y especialmente el grado de integración son los factores objetivos más influyentes, teniendo en cuenta que los parámetros del color y el patrón podrían ayudar a mejorar la integración. El creciente uso de herramientas informáticas para este tipo de estudios puede facilitar enormemente el análisis conjunto de factores objetivos en futuros estudios, como ha ocurrido recientemente en investigaciones destinadas a estudiar el color y el deslumbramiento a partir del concepto de prominencia visual (Xu et al., 2017).

\subsubsection{Aplicación a la localización y la evaluación del impacto ambiental}

En la literatura encontramos numerosos ejemplos donde se combinan sistemas SIG con métodos de toma de decisiones multicriterio, optimización multiobjetiva, o enfoques probabilísticos para decidir la ubicación destinada a implantar sistemas de energía solar (Sánchez-Lozano et al., 2016).

El uso del suelo se incluye a menudo en el problema de elegir la localización como una restricción (Arán et al., 2008; Azevêdo et al., 2017; Borgogno et al., 2015; Sánchez-Lozano et al., 2016; Suuronen et al., 2017). Sin embargo, los diferentes subimpactos y los factores objetivos discutidos en esta tesis no se suelen considerar, con la excepción de dos trabajos que tienen en cuenta la visibilidad de los sistemas de energía solar: (Landscape Institute, 2013; Suuronen et al., 2017). 
Respecto a este tema resulta interesante un estudio en el que se revisaron 29 proyectos italianos de energías renovables que contaban con su correspondiente informe de evaluación del impacto ambiental (EIA), incluyendo siete proyectos con sistemas fotovoltaicos (Tolli et al., 2016). La comprobación de que todos los proyectos hacían mención indirecta del impacto estético se hizo atendiendo a los 5 componentes que establece la Guía para la evaluación de los caracteres del paisaje en Inglaterra y Escocia (Tudor, 2014). De acuerdo con esto, todos los proyectos fotovoltaicos consideraron la componente visual del sistema, dos consideraron además los efectos en la componente morfológica simbólica y cromática, mientras que en otro se llegó a tener en cuenta el impacto de la limitación del disfrute y las características connotativas.

El análisis de la percepción del impacto estético a través de encuestas o entrevistas para entender el punto de vista de las personas implicadas no se incluye normalmente en los informes de EIA para los proyectos de sistemas solares (Tolli et al., 2016). Predecir la percepción humana basándose en factores objetivos resolvería esa carencia, especialmente cuando en estos estudios podría ser necesario seleccionar la mejor opción comparando la percepción en varios escenarios.

La selección del mejor lugar y la evaluación del impacto ambiental para construir un huerto solar fotovoltaico debería producir la mínima perturbación en el paisaje. Para ello, se deberían escoger los factores objetivos apropiados para mejorar su percepción estética a través de los tres sub-impactos propuestos en el marco metodológico: "uso del suelo" (no solo como restricción y dependiendo del tamaño y de la cualidad del uso del suelo), "SES" (dependiendo de la visibilidad y del grado de integración) y "deslumbramiento" (dependiendo de la visibilidad). Además, la integración de otros métodos para estimar la visibilidad basados en su observabilidad (Fernandez-Jimenez et al., 2015; García-Garrido et al., 2012) y el riesgo de deslumbramiento (Ho et al., 2015; Rose and Wollert, 2015) con métodos actuales basados en SIG, deberían conducir a resultados para mejorar la percepción estética de los habitantes de la zona.

\subsection{Percepción social de la integración urbana de la energía solar}

La investigación que se llevó a cabo para evaluar la percepción real de los ciudadanos frente a los sistemas de energía solar instalados en los edificios se resume en el capítulo 3 y dio lugar a una publicación en la revista científica "Sustainable Cities and Society" (Sánchez-Pantoja et al., 2018b). El trabajo tenía como finalidad principal el análisis subjetivo de la percepción estética de los SES, evaluando las emociones que provocaban en las personas encuestadas. Sin embargo, los datos permitieron demostrar la influencia que tiene en los resultados el hecho de que el observador pueda apreciar y entender la instalación o no, confirmando así la relevancia de la visibilidad y del grado de integración del sistema en el impacto estético percibido, tal y como se describe de forma detallada en el capítulo 2. 
A continuación, se argumenta la validez de la muestra considerada de acuerdo con los resultados obtenidos en una primera fase de encuestas realizadas en Versalles. En los apartados siguientes, se discuten los resultados referentes a la valoración general en valencia hedónica y arousal, y se analiza la comparación de las valoraciones obtenidas por los sistemas BIPV y los sistemas BAPV.

\subsubsection{Validez de la muestra}

El análisis de la percepción estética de los SES en los edificios, desde el punto de vista subjetivo, se llevó a cabo mediante encuestas utilizando como escenario de evaluación la exposición de prototipos de viviendas solares del concurso internacional Solar Decathlon Europe, celebrado en 2014 en Versalles (ver capítulo 3). Dado que el evento solo tiene una duración de dos semanas, la recogida de datos se realizó en dos fases con la finalidad de obtener una muestra suficientemente significativa para el estudio. Primero, durante las dos semanas de exposición de los prototipos, se realizaron encuestas in situ obteniendo un total de 87 encuestas. Posteriormente, se realizaron encuestas "online" utilizando fotografías, teniendo siempre en cuenta que las imágenes tuvieran un punto de vista y un ángulo de visión similar al que tiene un peatón a nivel de calle. En total, se obtuvieron 253 encuestas de los prototipos con sistemas BIPV y 165 con sistemas BAPV.

La comparación de los datos obtenidos in situ y las encuestas online permitieron comprobar la validez ecológica (o estadística) de los resultados. En la tabla 3 del capítulo 3 podemos ver que los valores de la valencia fueron ligeramente superiores utilizando fotografías, mientras que la activación provocada por los edificios evaluados fue un poco mayor en presencia de los prototipos. Estos resultados eran previsibles si se tiene en cuenta que hay algunos factores que influyen en el proceso, como la calidad estética de la fotografía que nos puede mostrar la mejor perspectiva del prototipo en unas condiciones climáticas óptimas. En cambio, los encuestados en Versalles habían podido ver todas las fachadas y las condiciones climáticas eran aquellas que prevalecían en dicho momento. También el tiempo de exposición frente al prototipo es diferente: mientras que las fotografías son observadas durante aproximadamente un minuto, los visitantes del SDE dedicaron varios minutos a visitar cada prototipo. Otro factor que podría influir es el hecho de que generalmente en Versalles los visitantes son informados sobre cómo funcionan las instalaciones, información que no está disponible para las personas encuestadas que respondieron la encuesta online con fotografías.

Sin embargo, a pesar de que los resultados de la prueba $t$ y los factores comentados pudieron causar cierto desequilibrio en la percepción de prototipos reales vs. fotografías, la validez estadística de los datos obtenidos mediante fotografías se consideró aceptable, puesto que dentro de la escala de valores de 1 a 7 siempre se obtuvieron puntuaciones similares. Podemos afirmar que los resultados obtenidos 
con las fotografías, por tanto, son válidos para predecir si la instalación se ve como más o menos agradable y si el observador se siente estimulado o no.

\subsubsection{Valoración general de la valencia hedónica y el grado de excitación}

De acuerdo con las conclusiones del estudio descrito en el capítulo 2, la percepción de una instalación desde el nivel de calle varía en función del grado de integración y de su visibilidad en el conjunto del diseño del edificio. Por tanto, estos parámetros se deben tener en cuenta al exponer y realizar la discusión de los resultados obtenidos con un enfoque subjetivo. Precisamente, además de distinguir entre prototipos con sistemas BIPV y BAPV, en este estudio se consideraron 3 categorías según el siguiente criterio: 1) la instalación se ve, se percibe y se entiende perfectamente; 2 ) se ve y se percibe parte de la instalación; y 3) la instalación no se ve. Las imágenes de los 20 prototipos utilizados pueden verse en la figura 3.3 (capítulo 3) y la información de cada instalación está ampliada en el documento complementario de ese mismo capítulo. Es importante recordar que la valoración de las dos variables (valencia hedónica y nivel de activación) se realizó mediante una escala gráfica (SAM) donde el valor mínimo es 1 (desagrado total y baja activación, respectivamente), el valor medio es 4 y el valor máximo es 7 (máximo agrado y activación, respectivamente).

Viendo los resultados para la valencia hedónica en la figura 3.7 (capítulo 3), podemos afirmar que en términos generales la percepción es positiva, puesto que solo el $20 \%$ de los prototipos se valoraron por debajo del 4. Estos resultados confirman la hipótesis planteada y cumplen con el objetivo de conocer si el impacto que producen los sistemas de energía solar utilizados en los edificios es positivo o negativo.

Independientemente de que el sistema sea BIPV o BAPV, y con la excepción de 3 prototipos (Orchid house, Casa System y Ressò), observamos una tendencia clara e interesante que consiste en que a mayor visibilidad de la instalación (se ve más y se percibe más fácilmente), peores puntuaciones en valencia hedónica (es decir, se percibe como más desagradable). Dicha tendencia coincide y refuerza los resultados obtenidos en el estudio que se describe en el capítulo 2 respecto a los factores objetivos más influyentes (visibilidad de la instalación y grado de integración). A mayor visibilidad y peor integración, por tanto, peor valoración en términos de agradabilidad puesto que se les asignan menores puntuaciones en la dimensión de valencia hedónica. Podemos afirmar que estos resultados serán de gran interés para el diseño de futuras instalaciones, puesto que cuanto más capaz sea el diseñador de integrar, ocultar y disimular la instalación, mayor será la aceptación estética del resultado. Excepcionalmente, si miramos los resultados de los tres casos que no cumplen con esta tendencia, es interesante comentar que los tres pertenecen a la categoría 2, tienen formas geométricas simples y utilizan materiales plásticos como recubrimiento superficial. La suma de estas características parece estar influyendo realmente en la baja aceptación estética. 
Respecto a la dimensión de intensidad emocional (arousal o activación), como puede verse en la figura 3.8 (capítulo 3), todos los prototipos han obtenido valores comprendidos entre 3 y 5 , reflejando de esa manera un grado de excitación medio. Por lo tanto, no existe una relación clara entre las tres categorías establecidas y los valores obtenidos. Estos resultados son congruentes con los datos de investigaciones previas sobre la evaluación afectiva de imágenes estandarizadas, como el Sistema Internacional de Imágenes Afectivas (IAPS) (Lang et al., 1997; Moltó et al., 2013), puesto que las escenas de casas suelen considerarse neutras (valores medios en valencia afectiva) pero además son evaluadas con un nivel de activación bastante bajo, o lo que es lo mismo de "calma". Es más, los resultados de este trabajo mostraron bastante dispersión en la valoración subjetiva de arousal para las imágenes que se habían considerado más placenteras (valencia hedónica > 5), confirmando así que la valencia afectiva es independiente del nivel de excitación provocado por los estímulos visuales que se están valorando.

\subsubsection{Comparación BIPV vs. BAPV}

Como podemos observar en la tabla 4 del capítulo 3, en términos de valores medios totales para valencia afectiva y excitación, los valores obtenidos por la muestra 2 (encuestas con sistemas BIPV) son mayores que las de la muestra 3 (encuestas con sistemas BAPV). La valoración de los prototipos es en general positiva, con un grado de excitación medio-bajo para las dos muestras.

Los resultados de la prueba t resumidos en la tabla 5 del capítulo 3, muestran que no se asume la igualdad de medias entre las dos muestras para ninguna de las dos variables estudiadas. Es decir, que hay diferencias significativas en la valoración recibida por los sistemas BIPV y BAPV, que compensarían el incremento de trabajo requerido para desarrollar las tecnologías BIPV, así como la inversión económica inicial necesaria para instalarlas, obteniendo una puntuación un poco más alta. Si la integración fotovoltaica no se considera desde la fase del diseño de la construcción, el resultado es un edificio estéticamente menos atractivo (Johnston, 2007), lo cual se ha demostrado también en estudios recientes (Lobaccaro et al., 2019). Aunque la tecnología BIPV se perciba generalmente como cara o incluso como de coste prohibitivo (Yang and Zou, 2016), esto no parece tener una repercusión negativa en la percepción estética. Presumiblemente, el encuestado ha percibido que también es necesaria una inversión económica para las tecnologías BAPV y, en consecuencia, el coste económico no es un factor especialmente significativo en este estudio.

Con los datos comentados se cumple el objetivo de demostrar una mayor aceptación de los sistemas BIPV frente a los BAPV, confirmando además la hipótesis prevista. Sin embargo, no debemos olvidar que la valoración es bastante similar para las dos tecnologías y esta diferencia podría verse, por tanto, reducida si el encuestado percibe que la inversión económica y el desarrollo tecnológico requerido para la instalación de un sistema BIPV es muy alto. También hay estudios que defienden que 
hay factores que limitan la aplicabilidad de estos sistemas en diferentes países, como las políticas económicas y energéticas, o las condiciones climatológicas y geográficas (Radmehr et al., 2014).

Si tenemos en cuenta la visibilidad de la instalación y la categorización que hemos hecho en el apartado anterior, encontramos cierta incertidumbre en los prototipos BAPV del grupo 3 (Renai, Casa System y Ressò), puesto que estas casas podrían confundirse con aquellas que tienen un sistema BIPV en cubierta de forma que la instalación no se ve desde ningún punto. Sin embargo, el cálculo de la comparación mediante la prueba $\mathrm{t}$ excluyendo estos tres prototipos mostró resultados muy similares a los obtenidos sin excluirlos.

En cuanto a la influencia de los parámetros sociodemográficos en la percepción estética, en la tabla 6 del capítulo 3 podemos ver los resultados de las pruebas que se llevaron a cabo. El único parámetro que reveló tener una influencia clara en las dos variables (valencia hedónica y nivel de activación) fue la edad. Tanto para la tecnología BIPV como para la BAPV, cuanto más joven es el encuestado mayor grado de activación experimenta. También en el caso de la valencia hedónica, cuanto más joven es el encuestado mayor es la valoración en el caso de los prototipos con sistemas BAPV. Esto indica que, de forma general, la gente mayor se impresiona menos y están menos dispuestos a aceptar la estética industrial ofrecida por las soluciones BAPV no integradas. Estos datos están en línea con los aportados por estudios previos que utilizan el SAM para evaluar imágenes afectivas del Sistema Internacional de Imágenes Afectivas (IAPS). En dichos estudios, los resultados muestran una mayor intensidad afectiva en personas más jóvenes, pero también un mayor control emocional y afecto positivo en personas de edad más avanzada (Backs et al., 2005). Finalmente, para las imágenes agradables, el grupo de más edad experimenta menor intensidad emocional que las personas más jóvenes (Grühn and Scheibe, 2008).

En este estudio, la mayoría de los participantes mostraron un alto grado de preocupación por el medio ambiente. Los resultados respecto al uso de los sistemas BIPV indicaron que la gente más concienciada con el medio ambiente otorgaba a los prototipos puntuaciones más altas, tanto para la valencia afectiva como para el grado de excitación.

Aunque las tablas 3 y 4 del capítulo 3 muestran algunas diferencias, los resultados del análisis estadístico sugieren que el género no tiene ninguna influencia sustancial en la percepción estética de los participantes. Estos resultados coinciden con los de otro estudio (Bradley et al., 2001), en el que se concluyó que a pesar de que las mujeres tienden a otorgar valoraciones más extremas en la dimensión de la valencia hedónica (especialmente en el caso de las imágenes desagradables), las reacciones afectivas frente a eventos normales de la vida (tanto agradables como desagradables) son muy similares para hombres y mujeres. 
Finalmente, la relación de los encuestados con la arquitectura y su lugar de residencia mostró una cierta influencia en la evaluación de la percepción estética, pero la muestra no es suficientemente representativa en estos parámetros para poder considerar estos resultados como concluyentes. Aun así, los resultados coinciden con los de otro estudio que concluye que la evaluación realizada por arquitectos y no arquitectos es diferente (Gifford et al., 2000).

En conclusión, podemos afirmar que se ha cumplido también el objetivo de identificar los parámetros sociodemográficos que influyen en la percepción estética, siendo la edad el único que reveló tener una influencia clara en las dos dimensiones afectivas, valencia hedónica y arousal. Además, la hipótesis planteada de que la gente joven mostraría una mayor aceptación a estas nuevas tecnologías se confirma con los resultados obtenidos.

\subsection{Implicación europea en la integración urbana de energías renovables y su aceptación social}

El análisis de la implantación efectiva de energías renovables a escala urbana en el ámbito europeo y la implicación respecto al impacto estético que producen este tipo de proyectos se ha presentado en la investigación descrita en el capítulo 4, que está por el momento pendiente de ser aceptada para su publicación en la revista científica Energy Policy.

El principal foco de interés del estudio fueron los proyectos con financiación europea destinados a la implementación real de sistemas de energías renovables a escala urbana. De acuerdo con los resultados obtenidos en los trabajos descritos en los capítulos 2 y 3 acerca de la visibilidad y el grado de integración como factores más relevantes en el impacto estético, solo se tuvieron en cuenta para esta investigación aquellos proyectos con instalaciones visibles, que los ciudadanos puedan percibir (puesto que, de no ser así, no se produce un impacto estético). Esto implica que proyectos destinados, por ejemplo, a la implantación de un sistema solar térmico para un barrio mediante la instalación de tuberías enterradas, de forma que los ciudadanos no perciben la instalación, quedarían descartados del estudio.

A continuación, se discuten los resultados principales del estudio, seguidos de un análisis desde una perspectiva temporal y política, así como en función del marco geográfico. Posteriormente, se tratará la necesidad de implicar a la ciudadanía en la transición energética, así como la importancia de considerar el impacto estético en los proyectos europeos y, por último, se examina la relación entre la estética y las convocatorias del programa H2020 puesto que ha sido la principal fuente de este estudio para encontrar proyectos que cumplieran los criterios de inclusión. 


\subsubsection{Discusión de los resultados}

Con la finalidad de cumplir con el objetivo de cuantificar los proyectos de financiación europea que ejecutan una instalación real, se llevó a cabo una profunda revisión de los 5 programas específicos considerados más relevantes en relación con la promoción de energías renovables y la mitigación del cambio climático. La primera conclusión que podemos obtener de este estudio es que, aunque los proyectos europeos tengan un claro interés en las energías renovables y los sistemas de almacenamiento de energía, se está llevando a cabo desde un punto de vista bastante teórico, enfatizando mucho la sensibilización, la difusión y la cooperación. Por lo tanto, resulta muy complicado proporcionar datos de demostradores reales con soluciones eficientes replicables en otros territorios. El estudio también pretende definir el grado de implicación de estos proyectos respecto al impacto estético que producen en la ciudad que, vistos los resultados, es más bien escaso.

Según los resultados que se muestran en la tabla 4 del capítulo 4, los sistemas de energía renovable más utilizados a escala urbana son el solar térmico, el fotovoltaico, el geotérmico y la biomasa. En cuanto al almacenamiento de energía, las baterías de litio, comúnmente asociadas a los sistemas de energía solar, parecen ser la solución más común. En general, como se muestra en la tabla 5 del mismo capítulo, el número de proyectos europeos destinados a la aplicación real y efectiva de sistemas de energía renovable a escala urbana es relativamente bajo, ya que sólo 16 de los 13989 proyectos examinados cumplen ese criterio (alrededor del 0,1\%); y el número de los que consideraron integrar sistemas de almacenamiento de energía fue aún menor. No obstante, todavía se prevé un aumento que optimizará esta situación puesto que, según la literatura, este tipo de proyectos es de vital importancia para combatir eficazmente el cambio climático, mejorar el rendimiento energético global de la localidad y conseguir ciudades más resilientes (Amado et al., 2016; Curreli et al., 2016; Luo et al., 2015; Perea-Moreno et al., 2018). En esa misma línea, términos como "comunidades sostenibles", "autonomía energética" o "autosuficiencia energética" son conceptos clave para definir el contexto de un desarrollo sostenible global, en el que se considera también el desafío técnico y las consecuencias sociales y políticas (Rae and Bradley, 2012).

De acuerdo con las recomendaciones del informe de la Agencia Internacional de Energía Renovable (IRENA, 2017), actualmente la investigación manifiesta un gran interés por incluir los sistemas de almacenamiento de energía en los modelos energéticos urbanos (Amirante et al., 2017; Cebulla et al., 2018; Luo et al., 2015; Navarro et al., 2016, 2015). Desde el punto de vista de la red eléctrica, algunos estudios sugieren que se necesita una mayor capacidad de almacenamiento para mitigar los costes de gestión debidos a la variación de carga que supondría en la red el uso de energías renovables, aunque la optimización mediante la inclinación y la orientación de los sistemas fotovoltaicos, o mediante la agregación de la demanda de varios edificios, minimiza las necesidades de almacenamiento (Freitas et al., 
2018). Además, hay investigaciones que afirman que "la optimización que se realiza introduciendo un conjunto de sistemas de almacenamiento eléctrico eleva la capacidad óptima del sistema fotovoltaico y ofrece mayor flexibilidad para el autoconsumo y, por consiguiente, tiene potencial para ampliar enormemente la instalación de la energía fotovoltaica urbana" (Lovati et al., 2018). Lamentablemente, la revisión realizada ha demostrado que la aplicación real y efectiva de la energía solar fotovoltaica a escala urbana mediante proyectos europeos es todavía bastante escasa, sobre todo incluyendo sistemas de almacenamiento de energía.

En el campo de la energía térmica, el alcance de los proyectos examinados parece mayor, aunque no se han incluido finalmente en nuestro estudio (salvo que se combinen con otros sistemas de energía renovable) porque suelen estar enterrados, sin tener por tanto un impacto visual significativo (para una revisión de los sistemas de calefacción y refrigeración de los distritos, véase Werner (2017). A este respecto, encontramos un estudio que propone un nuevo concepto -el llamado "modelo de energía de edificios urbanos (MEEU)"- que utiliza métodos de simulación para referirse a una herramienta de planificación clave para los servicios públicos, los municipios, los planificadores urbanos e incluso los arquitectos que trabajan en proyectos a nivel de complejos urbanos de edificios (Reinhart and Cerezo, 2016). Sería interesante para futuras investigaciones incluir en los MEEU simulaciones de consumo, generación de electricidad a partir de energías renovables (principalmente de sistemas BIPV) y sistemas de almacenamiento, con el objetivo de crear una herramienta de análisis más compleja que ayude a establecer estrategias de política energética más eficientes y sostenibles para las ciudades.

En el estudio descrito en el capítulo 2 hemos visto la importancia del proceso de selección de la localización para los SES en los entornos rurales, donde el uso del suelo se considera a menudo una restricción en función de las características o la calidad del suelo que se vaya a ocupar. En los proyectos europeos para el fomento de las energías renovables en la ciudad que incluyan sistemas solares, esto no tiene importancia si trabajamos con tecnologías BIPV que forman parte de la envolvente de los edificios, pero la localización urbana de otros tipos de SES debería suponer un proceso al que prestar especial atención. Recogiendo los argumentos del capítulo 2, se deberían escoger los factores objetivos apropiados que permitieran mejorar la percepción estética a través de los tres sub-impactos propuestos: uso del suelo (no solo como restricción, y dependiendo del tamaño y de la cualidad del uso del suelo urbano a ocupar), SES (dependiendo de la visibilidad y del grado de integración), y deslumbramiento (dependiendo de la visibilidad a nivel de calle y desde los edificios próximos).

Sin embargo, no debemos olvidar que, de acuerdo con los resultados del estudio descrito en el capítulo 3, los sistemas BIPV gozan de una mayor aceptación estética que los sistemas BAPV. En consecuencia, resulta altamente recomendable fomentar 
el desarrollo y la implantación de tecnologías BIPV en los proyectos europeos, que no tienen por qué limitarse a la envolvente de los edificios, sino que deberían extender también su uso a otros elementos comunes del entorno de la ciudad como pueden ser el mobiliario urbano, las marquesinas, los quioscos, etc. De esta forma, se pueden proponer sistemas BIPV, haciendo referencia a su integración en edificios (building-integrated PV), pero también podrían desarrollarse sistemas UFIPV (urbanfurniture-integrated PV) de uso específico en elementos urbanos de uso comunitario.

\subsubsection{Análisis temporal y político}

La figura 4.4 (capítulo 4) muestra la evolución a lo largo del tiempo, desde el año 2000, para los 63 proyectos que superaron el segundo filtro por su relación con la implementación de energías renovables en la ciudad. En la figura cada proyecto está contabilizado en todos los años que dura el programa al que pertenece y podemos ver tres etapas claramente diferenciables, que tienen similitudes con estudios previos sobre el gasto público en investigación y desarrollo para la transición de las energías renovables en Europa (Bointner et al., 2016).

La financiación para nuevas fuentes de energía alternativas a los combustibles fósiles comenzó a principios de los años setenta, durante la guerra árabe-israelí. Más tarde, a finales de los noventa, hubo un nuevo impulso a las energías renovables (Bointner et al., 2016). A lo largo de estos primeros años, los esfuerzos se dirigieron al medio rural en forma de parques eólicos, plantas fotovoltaicas o plantas de biomasa, entre otros. El registro de proyectos de financiación europea que en su título y en el resumen mostraban la intención de implementar energías renovables a escala urbana (pasando así el segundo filtro de la investigación), comenzó en el año 2000. De esta forma, la primera etapa comprende claramente un período de tiempo de 6 años (2000-2006), como se muestra en la figura 4.4 (capítulo 4). Esta etapa se caracteriza por una pequeña cantidad anual de proyectos (3 0 4) que pasaron el segundo filtro, y un solo proyecto que pasó el tercer filtrado (es decir, que en la información de la web del proyecto se hace mención expresa de la implementación real de energías renovables a escala urbana).

La segunda etapa comprende los años 2007-2013, coincidiendo con la crisis económica. Como puede verse en la figura, el año 2007 marcó un punto de inflexión para la política climática y energética de la Unión Europea (EU, 2008), con el acuerdo de establecer objetivos sobre las emisiones de gases de efecto invernadero (una reducción de al menos el $20 \%$ para 2020, a partir de la línea de base de 1990), la eficiencia energética (ahorro del $20 \%$ para 2020, expresado en términos absolutos), y la adopción de energías renovables (consecución de una cuota del $20 \%$ de energías renovables en el consumo de energía de la UE para 2020). Ese mismo año, la Comisión Europea también publicó el Plan Estratégico de Tecnología Energética (conocido como SET Plan) (EU, 2007), cuyo objetivo era coordinar los esfuerzos de 
financiación de la UE, nacionales y privados en materia de investigación y desarrollo tecnológico, a fin de acelerar la transformación de la UE hacia un modelo energético con bajas emisiones de carbono (Moseley, 2017). En esta etapa, un número importante de proyectos del Programa Interreg superaron los criterios establecidos en el segundo filtro, aunque la mayoría de ellos fueron descartados posteriormente a lo largo de la tercera etapa de filtrado puesto que estaban enmarcados exclusivamente en intervenciones políticas, en lugar de seguir un enfoque práctico o empírico (Spurling et al., 2013), o porque afectaban a edificios individuales sin integración urbana.

Finalmente, la tercera etapa (a partir de 2013) muestra un crecimiento continuo de proyectos potenciales, con acciones relacionadas con la implementación real de energías renovables en entornos urbanos (pasando así la tercera etapa de filtrado del estudio). Estos proyectos fueron financiados por los programas FP7 y H2020. En ese periodo, concretamente en 2014, la Comisión Europea propuso unos objetivos de eficiencia energética ambiciosos para 2030 (EU, 2014), como la reducción del 40\% de las emisiones de gases de efecto invernadero con respecto a la línea de base de 1990, o la participación del $27 \%$ en el consumo de energía renovable. Posteriormente, a finales de 2016, la Comisión Europea presentó un paquete de medidas con el fin de posicionar a la Unión Europea como líder de la transición a la energía limpia (EU, 2016). Uno de los principales objetivos era situar a los consumidores en el centro de la Unión Energética.

Con los resultados mostrados en la figura 4.4, vemos que en cierta forma se confirma la hipótesis de que, como reflejo de los compromisos y las estrategias energéticas establecidas en los últimos años por la Unión Europea, existe una tendencia a financiar cada vez más proyectos innovadores que impliquen una instalación efectiva de sistemas de energías renovables a nivel urbano. Sin embargo, dado que la revisión se realizó a finales de 2018, no se tuvieron en cuenta en el estudio todos los proyectos financiados en las convocatorias europeas a partir de ese año, lo que explica que esa tendencia al aumento de proyectos en el último período alcance su punto máximo en 2017. Es de esperar que, incluyendo los proyectos seleccionados en convocatorias posteriores, la tendencia mencionada seguiría aumentando.

\subsubsection{Marco geográfico}

La información obtenida, consultando las páginas web de los 16 proyectos seleccionados tras el tercer proceso de filtrado, permitió analizar la implicación en proyectos con instalación real de energías renovables a escala urbana desde el punto de vista geográfico. Podemos ver en la figura 4.5 (capítulo 4) que España es el país que más destaca, tanto por su participación como por su rol de coordinador en los proyectos financiados revisados. De hecho, España y Bélgica son los países que han participado en un mayor número de proyectos (69\%), seguidos de Italia (56\%) y Alemania (50\%). Ciertamente, estos resultados contrastan con los datos estadísticos 
correspondientes al número de países que actúan como coordinadores de los proyectos. Así, aunque España ha coordinado el $44 \%$ de los proyectos, Bélgica solo ha coordinado uno, y Alemania e Italia ninguno. Tanto en Europa del norte como del este la participación ha sido bastante baja, y muchos países del este de Europa no han participado en ninguno de los proyectos revisados.

Es interesante destacar que, durante este proceso de validación, se detectó que los motivos para participar en este tipo de proyectos son muy diferentes en países no europeos y en entornos menos desarrollados (motivados, por ejemplo, por la falta de suministro de electricidad en algunas zonas subdesarrolladas). Además, para algunos países con una implementación más tardía y menos extendida de la energía solar (como España), el enfoque principal del trabajo científico es mejorar la eficiencia, pero reduciendo el coste. Sin embargo, otros temas relevantes como la aceptación social, la solidaridad entre vecinos (es decir, cuantificar y compartir la energía) o la percepción estética nunca se han considerado prioritarios.

\subsubsection{La implicación ciudadana en la transición energética}

Sin lugar a duda, la implementación y la integración de energías renovables en la ciudad a nivel de barrio afecta a los ciudadanos, especialmente a los residentes y a la gente que trabaja o circula por las zonas afectadas. Sin embargo, en los proyectos analizados no encontramos como socios a asociaciones de vecinos o entidades que los representaran, lo que significa que la ciudadanía únicamente estaba representada por la propia administración local, por agencias o por ONGs, con la excepción del proyecto SmartEnCity, en el que la Asociación de la Vivienda B42 era miembro del consorcio. Por tanto, podríamos considerar que las tres dimensiones de la aceptación social (sociopolítica, comunitaria y de mercado) (Wüstenhagen et al., 2007), en general no están bien representadas. Esto coincide con las conclusiones de un trabajo donde se afirma que pocos estudios sobre la aplicación de las energías renovables y el almacenamiento de energía incluyen más de uno de estos tres aspectos en sus respectivos marcos analíticos (Devine-Wright et al., 2017). Además, varios estudios destacan la necesaria participación e implicación de los residentes para promover la aceptación social en este tipo de proyectos (Flacke and de Boer, 2017; Langer et al., 2017; Strazzera and Statzu, 2017; Zoellner et al., 2008). En consecuencia, sería recomendable promover la inclusión del sector social como parte del consorcio que desarrolla el proyecto, a fin de mejorar los resultados de la aceptación social. $\mathrm{O}$, en su defecto, sería conveniente que las políticas europeas exigieran la inclusión de la ciudadanía afectada en acciones concretas previstas en los proyectos.

No debemos olvidar que la transición energética requiere un cambio en la conciencia, los hábitos y el comportamiento de la sociedad para que las iniciativas sean realmente efectivas, lo que justifica aún más la participación activa de la ciudadanía en todo el proceso. 


\subsubsection{El impacto estético}

Sabemos que existen varios factores que podrían influir en la aceptación social de las energías renovables en los proyectos, como la percepción de que son una fuente limpia y renovable, los aspectos económicos, la concienciación, la educación, la preocupación por el medio ambiente, el uso de la tierra, etc. Hoy en día, el impacto estético de los sistemas implementados ha comenzado a ser considerado como uno de los factores más importantes en cuanto a la tolerancia social. De hecho, varios estudios que incluyen entornos rurales y urbanos se han centrado en la percepción estética del despliegue de los sistemas de almacenaje de energía, en relación con sus impactos ambientales (Chen et al., 2013; Chiabrando et al., 2011; Kapetanakis et al., 2014; Mérida-Rodríguez et al., 2015; Sánchez-Pantoja et al., 2018b; Scognamiglio, 2016; Tolli et al., 2016; Torres-Sibille et al., 2009; von Möllendorff and Welsch, 2017). Especialmente en los entornos urbanos, el aspecto visual de los sistemas de energías renovables parece tener mucho peso en las preferencias del usuario final (Bao et al., 2017; Lu et al., 2018). En general, como se ha visto en el estudio del capítulo 2, tener en cuenta el impacto visual causado en la ciudad por la implementación de las energías renovables resulta ciertamente imperativo.

Sin embargo, en la literatura revisada no se pudo encontrar ninguna estrategia específica para evaluar el impacto estético de los sistemas de energías renovables, ni de los sistemas de almacenamiento de energía implementados. Según el marco metodológico propuesto en el segundo capítulo, recordemos que "el impacto estético se descompone en tres sub-impactos: uso del suelo (que depende del tamaño y de la cualidad del uso del suelo), sistema de energía solar (que depende tanto de la visibilidad como del grado de integración) y deslumbramiento (que depende de la visibilidad). Considerando estos tres sub-impactos, un sistema de energía solar que se vea y no esté bien integrado tendría el mayor impacto estético porque afecta, en mayor o menor medida, a los tres sub-impactos. Estas conclusiones parecen especialmente aplicables a la energía solar térmica, porque tiene un menor grado de integración con el entorno debido a los depósitos y a los componentes del sistema. A este respecto, China parece ser uno de los países que más esfuerzo ha hecho para intentar integrar sistemas solares térmicos en la envolvente de grandes edificios residenciales pero, pese a su empeño y la variedad de soluciones utilizadas que podemos encontrar en un estudio reciente (Huang et al., 2019), no encontramos aún sistemas que podamos considerar estéticamente integrados en el diseño arquitectónico del edificio. Sin embargo, un informe del proyecto de la Agencia Internacional de la Energía de 2014 ya mostraba diseños muy sugerentes para conseguir la integración deseada incluso con los sistemas solares térmicos (Munari et al., 2014). En el caso de los sistemas BIPV, resulta más sencillo reducir el impacto estético con un grado de integración adecuado (color, modulación, textura, etc.), evitando además el deslumbramiento. Como ejemplo, podemos ver numerosos casos de éxito en el informe del mismo proyecto de la Agencia Internacional de la Energía (Frontini et al., 2012). Por último, las calderas de 
biomasa o los sistemas geotérmicos no tienen un impacto estético provocado por la visibilidad, ni por el grado de integración, ni por el deslumbramiento, porque son sistemas que funcionan con conductos enterrados que quedan ocultos. En estos casos, aunque debe tenerse en cuenta que sí hay un uso real de suelo en la ciudad, aunque generalmente se realiza en espacio de propiedad privada.

La misma dificultad que encontramos para integrar estéticamente los depósitos de los sistemas solares térmicos aparece en la implementación de sistemas de almacenamiento de energía. Dichos sistemas son necesarios para llevar a cabo la transición energética y ecológica y, por tanto, provocarán un indudable impacto estético en la ciudad que no puede ser ignorado. Del mismo modo, los investigadores no deben ignorar que será necesario el espacio público disponible en las ciudades si se quieren aplicar soluciones innovadoras que mejoren la gestión de la energía desde un punto de vista colectivo y ser así más eficientes. El uso del suelo, la visibilidad y el grado de integración han demostrado ser factores determinantes del impacto estético de estos sistemas. Pero la tendencia habitual a la hora de implementar las energías renovables en los proyectos no es la de afrontar y dar solución a un problema de falta de espacio o de integración estética. Muy al contrario, la tendencia parece ser la de ignorar que existe un impacto y ocultar, en la medida de lo posible, las instalaciones en el interior de edificios o utilizar soluciones enterradas.

En el planteamiento inicial de la investigación, se preveía una escasa implicación de los proyectos europeos que implantan energías renovables a escala de barrio con la evaluación del impacto estético que producen en la sociedad; pero se sospechaba una tendencia al alza de la preocupación por ese impacto en los próximos años. Sin embargo, los resultados del análisis de los proyectos nos muestran una falta total de concienciación respecto al impacto estético y una carencia total de métodos para su evaluación. Además, la sorpresa mostrada por el personal técnico participante en estos proyectos al ser preguntados al respecto, no sugieren una tendencia positiva que, como se ha justificado, sería necesaria para promover un desarrollo coherente y que facilite el bienestar de los ciudadanos en las ciudades del futuro.

\subsubsection{La estética en el programa H2020}

Actualmente, la política científica incorpora objetivos de política pública en un intento de aumentar la transferencia de las contribuciones de la ciencia a la sociedad, como soluciones plausibles a los problemas sociales relevantes. Los científicos han respondido a esta nueva estrategia de financiación señalando que sus campos y temas son particularmente prometedores. No cabe duda de que, además del engaño provocado por la financiación selectiva, esa financiación también ha aumentado la investigación sobre los temas previstos (Gläser and Laudel, 2016). En todas las convocatorias de financiación relacionadas con la energía del programa H2020 se realizó un análisis más profundo de las interrelaciones entre la política científica y 
los objetivos de política pública. De hecho, el mayor número de proyectos que superaron el tercer filtrado del estudio estaban financiados en este programa.

Horizonte 2020 se centra en tres pilares principales: a) una ciencia excelente para reforzar la excelencia científica de categoría mundial de la Unión y hacer más competitivo el sistema de investigación e innovación europeo; b) el fomento del liderazgo industrial para acelerar el desarrollo de tecnologías que apoyen a las empresas y la innovación, incluso para las pequeñas empresas; y c) la solución de los problemas de la sociedad para responder a las prioridades identificadas en la estrategia Europa 2020. En este sentido, se está prestando atención explícitamente a la energía en el marco del desafío social 10 "Energía segura, limpia y eficiente" y las convocatorias dentro de este desafío suman un presupuesto total para la investigación no nuclear de casi 6.000 millones de euros para el período 2014-2020. Cada nuevo paquete de trabajo bianual (2014-2015 WP, 2016-2017 WP y 2018-2020 WP) adopta los refuerzos y actualizaciones del SET Plan (EU, 2007).

Las palabras clave "estética" y "visual" se incluyeron en la búsqueda realizada para los tres paquetes de trabajo del desafío. En los dos últimos paquetes de trabajo (EU, $2018,2016)$, la palabra clave 'visual' se relacionó con el confort visual considerado como una característica de la calidad ambiental interior, como es el confort térmico, la acústica o la calidad del aire. Sin embargo, no se encontraron resultados en el primer paquete de trabajo (EU, 2015). Durante el último paquete de trabajo, las ventanas fotovoltaicas transparentes, "visualmente no intrusivas" eran tecnologías previstas (aunque de TRL 3 a por lo menos 5) en la convocatoria LC-SC3-RES-2-2018 Innovación disruptiva en tecnologías de energía limpia (EU, 2018).

Durante el paquete de trabajo 2014-2015, la palabra "estética" apareció en una convocatoria de energías renovables (LCE 3 - 2014/2015), estando relacionada con la energía fotovoltaica integrada en el entorno de la construcción, como otras consideraciones arquitectónicas. Durante el siguiente paquete de trabajo, la palabra "estética" apareció también en una convocatoria, y además la estética fue uno de los criterios del Premio Horizonte para Sistemas Fotovoltaicos Integrados en Distritos Urbanos Históricos Protegidos Europeos. En el paquete de trabajo 2018-2020, la palabra "estética" apareció también en una convocatoria relacionada con los sistemas BIPV (LC-SC3-RES-6-2018), y como novedad en una convocatoria (LC-SC3EC-1-2018-2019-2020) para desarrollar actividades que informen y motiven a los consumidores a cambiar los viejos e ineficientes aparatos instalados por soluciones de calefacción y/o refrigeración más eficiente y de energía limpia.

Los cambios introducidos en el SET Plan como consecuencia de las medidas del conjunto de medidas Energía limpia para todos los europeos (EU, 2016) reorientaron el Programa de Trabajo sobre Energía 2016-2017 en comparación con su predecesor de 2014-2015, haciendo especial hincapié en permitir a los consumidores participar activamente en la transición energética. Las consecuencias para el impacto estético 
de las energías renovables son la consideración del confort visual y el aumento de la conciencia de las actividades para cambiar el mercado.

Estos paquetes de trabajo se alinean con el entendimiento dominante de los consumidores como individuos racionales, cuyos comportamientos y toma de decisiones están determinados por creencias y actitudes preestablecidas. Dentro de este paradigma, el cambio de comportamiento pro-ambiente se centra en la toma de decisiones y la elección. Por lo tanto, a menudo se orienta facilitando la provisión de información y la sensibilización (Foulds and Christensen, 2016).

En este punto se quiere destacar la recomendación de que las convocatorias de financiación empiecen a considerar las tecnologías como productos y componentes básicos del trabajo y la vida cotidiana, en lugar de como un mero medio de intervención. En efecto, es esencial que el cambio tecnológico no se separe del cambio social (Foulds and Christensen, 2016). Y no solo eso, sino que la transición energética debe basarse en la educación de los ciudadanos como usuarios finales del producto. Para lograr un ahorro de energía eficaz y eficiente, parece sumamente importante cambiar los hábitos de consumo en primer lugar, concienciando a la población de que son usuarios reales que deben aceptar el reto de las energías renovables por su propio bien y el de las generaciones futuras. Debemos tener en cuenta que tener en consideración la opinión de la ciudadanía en relación con el impacto estético producido por estas tecnologías en el horizonte urbano podría evitar sin duda el rechazo de los futuros usuarios. El desafío de la transición energética podría considerarse un fenómeno de interacción entre el hombre y el medio ambiente $y$, por tanto, el enfoque de la investigación debería cambiar definitivamente con el fin de facilitar la transferencia de conocimientos al mundo real mediante la participación de las ciudades y de sus ciudadanos.

\subsection{Limitaciones de la investigación}

La investigación que se ha llevado a cabo en esta tesis doctoral tiene una serie de limitaciones que deben ser consideradas, partiendo de la premisa de que el impacto estético que producen los sistemas de energías renovables en la ciudad es un tema reciente, por lo que para algunas líneas de investigación abordadas en esta investigación la literatura previa era muy escasa o prácticamente inexistente.

Tengamos en cuenta que el marco metodológico propuesto, así como el establecimiento de los factores objetivos más influyentes en la percepción estética, presentan una limitación significativa por el hecho de que están basados totalmente en la literatura teórica y no hay datos empíricos que demuestren su validez. Sin embargo, dada la falta de coherencia y unanimidad entre los documentos revisados, este marco ha intentado sintetizar los resultados de las investigaciones precedentes, para establecer un punto de encuentro común que sirva de base a futuros estudios en el ámbito de la percepción estética de los sistemas de energía solar. 
Respecto a la evaluación de la percepción estética de los prototipos de viviendas solares del SDE2014, si bien es cierto que el análisis estadístico de los datos permitió comprobar la validez ecológica de los resultados, contar con una muestra más amplia y heterogénea hubiera hecho posible obtener resultados más concluyentes para todos los parámetros sociodemográficos considerados en el estudio. La baja representatividad de participantes que tuvieran una formación relacionada con el ámbito de la arquitectura, o que vivieran en grandes ciudades, no permiten justificar suficientemente la tendencia de estos grupos a dar valoraciones más altas en algunos casos (ver tabla 6 del capítulo 3).

Adicionalmente, podemos considerar una limitación del estudio la muestra de prototipos que se evaluó, puesto que no son casos reales de edificios integrados en la trama urbana de una ciudad. Sin embargo, la oportunidad de poder recopilar datos de diferentes sistemas solares en edificios de forma presencial ha permitido validar la obtención de datos mediante fotografías, siempre que se respete el punto de vista del observador de la calle. Esto permite ampliar la muestra fotográfica con casos existentes en futuros trabajos.

La investigación descrita en el cuarto capítulo es realmente innovadora en el ámbito de los programas europeos relacionados con la energía. Sin embargo, hay una clara limitación por ceñirnos a los 5 programas de financiación europeos considerados y al ámbito geográfico de Europa. Aun así, cabe destacar que se han revisado una gran cantidad de proyectos, casi 14000 . Adicionalmente, este trabajo tiene otra limitación respecto a la información disponible sobre los proyectos considerados. Algunos de los proyectos consultados cuentan con poca información en sus páginas web, sobre todo los más antiguos. Por otro lado, en el caso de los proyectos que llegaron a pasar el tercer filtro y que se les solicitó que respondieran la encuesta, una gran parte estaban en una fase muy inicial de desarrollo del proyecto, no siendo capaces de ofrecer información relevante sobre las instalaciones que se iban a instalar.

\subsection{Líneas de investigación futura}

Como se indica al inicio de la presente tesis doctoral, la investigación sobre el impacto estético producido por la integración de las energías renovables en la ciudad es muy reciente en la literatura, por lo que este trabajo pretende establecer un marco conceptual teórico que sirva de punto de partida a futuras investigaciones. Por ese motivo, las líneas de investigación futuras que se pueden plantear en este ámbito son variadas y se han agrupado por temáticas en los siguientes subapartados.

\subsubsection{Sobre el impacto estético}

La primera línea de investigación que se plantea es la verificación del marco metodológico propuesto en el capítulo 2 de esta tesis o la provisión de datos para 
mejorar su enfoque. El objetivo final sería poder predecir la aceptación estética social de las nuevas tecnologías de integración fotovoltaica en las fases de diseño.

Posteriormente, teniendo claro cuáles son los factores más influyentes en la percepción estética de los sistemas de energía solar, que además se han visto corroborados en otros estudios posteriores (Bevk and Golobič, 2020; Lobaccaro et al., 2019; Munari and Roecker, 2019), sería de gran interés definir una metodología sistemática que permita evaluar el impacto estético a partir de la parametrización de los factores más relevantes. Esta línea de investigación debería incluir un profundo análisis del factor del grado de integración para establecer criterios claros que eviten las incertidumbres actuales respecto al método a seguir para medirlo o cuantificarlo. Un estudio posterior a los presentados en esta tesis coincide precisamente en la necesidad de desarrollar una metodología experimental sistemática, que unifique criterios para evaluar los sistemas BIPV respecto a factores influyentes en la percepción como pueden ser la textura, el color, etc. (Xiang and Szybinska Matusiak, 2019). En este sentido, se podría tomar como base la metodología planteada por (Munari and Roecker, 2019) y contrastar su validez con datos reales de la percepción estética de la ciudadanía. Coincidimos con este estudio en que es necesaria una reflexión global de la arquitectura, pero enfatizando la necesidad de considerar en todo momento la percepción social. Sería de gran ayuda para los técnicos proyectistas y la industria del sector de la energía solar contar con una metodología para predecir la percepción y la aceptación estética de los SES.

Un enfoque que puede llevar a resultados interesantes sería analizar la percepción de los ciudadanos frente a cambios puntuales en entornos conocidos. El impacto percibido por un edificio de nueva construcción en el que se han integrado sistemas de energía solar podría diferir sustancialmente del impacto causado por una instalación realizada sobre la fachada de un edificio existente que ya es conocido por los usuarios del barrio.

Al margen de los factores objetivos, futuras investigaciones deberían combinar medidas indicativas de la percepción estética más allá de los cuestionarios de autoevaluación. Así se evaluaría con mayor precisión las reacciones afectivas vinculadas a dicha apreciación, independientemente de qué emociones específicas o dimensiones generales se enfaticen (Schindler et al., 2017). Estos trabajos deberían incluir observaciones del comportamiento en estudios de campo o en contextos de laboratorio (por ejemplo, movimientos oculares, tiempo de permanencia en un lugar específico, tiempo de visión o lectura, preferencia por entornos específicos, velocidad de movimiento y patrones de aproximación o evitación), y medidas fisiológicas (por ejemplo, actividad de la musculatura facial, actividad electrodérmica o cardiovascular, dilatación de la pupila o patrones de activación del cerebro).

Otro enfoque para futuras investigaciones sería explorar qué características personales podrían ser de ayuda para la experiencia y la percepción de emociones 
estéticas. Por ejemplo, la empatía (Eerola et al., 2016) o una actitud receptiva a la experiencia (Silvia et al., 2015) parecen facilitar que se experimenten emociones estéticas prototípicas. Por tanto, estudios futuros podrían ayudar a determinar si algunos rasgos de personalidad relevantes están más relacionados con emociones estéticas específicas, y si estas asociaciones entre personalidad y percepción emocional dan respuesta a las diferencias entre individuos en las preferencias estéticas en paisajes derivados de la implantación de sistemas de energía solar.

De forma similar, se necesitan más investigaciones que exploren la dinámica de la percepción estética. En el ámbito particular de los sistemas de energía solar, podríamos encontrar variaciones en la comprensión estética y en la apreciación del paisaje del mañana, incluso dentro de la misma localización y población. Esto significa que podrían vencerse percepciones estéticas negativas y con el tiempo desarrollarse nuevas preferencias (Nohl, 2001), o incluso que los sistemas de energía solar podrían formar parte de nuestro paisaje diario y la mayoría de la gente acostumbrarse a su presencia. En consecuencia, aunque podría ser prematuro alcanzar deducciones concluyentes en esta materia por el relativo corto tiempo de desarrollo de estos sistemas, la evaluación del impacto estético constituye un factor relevante a considerar en los progresos técnicos y en políticas de planificación futura.

En el caso de huertos solares en un entorno rural, para la selección del lugar idóneo se propone llevar a cabo estudios que integren los métodos actuales basados en SIG, con métodos de estimación de la visibilidad basados en su observabilidad (Fernandez-Jimenez et al., 2015; García-Garrido et al., 2012) y el riesgo de deslumbramiento (Ho et al., 2015; Rose and Wollert, 2015), lo que podría conducir a resultados que mejorasen la percepción estética de los habitantes de la zona.

\subsubsection{Relacionadas con los parámetros sociodemográficos}

Respecto a la investigación llevada a cabo en el capítulo 3, y de acuerdo con las limitaciones anteriormente detalladas, sería conveniente explorar las diferencias relevantes entre la respuesta estética de expertos y legos en la materia a la hora de evaluar la cualidad estética percibida del paisaje y el impacto del sistema de energía solar (Schindler et al., 2017). En el estudio que se describe en el capítulo 3 de esta tesis la representatividad de participantes con formación profesional relacionada con la arquitectura fue muy escasa (aproximadamente un 10\%). No obstante, los resultados mostraron una cierta influencia de este factor en la valoración de la percepción estética. Además, encontramos estudios anteriores que sugieren que la valoración de arquitectos y no-arquitectos es muy diferente (Gifford et al., 2000). Para poder confirmar la tendencia de los arquitectos a otorgar valores más altos en las dimensiones de valencia hedónica (agrado-desagrado) y activación (intensidad emocional), debería ampliarse la muestra experimental en futuros trabajos incluyendo una mayor representatividad del grupo de arquitectos. 
De modo similar, se detectó cierta influencia en los participantes que viven en grandes ciudades, puesto que tendían a dar puntuaciones más altas en los casos de edificios con sistemas BAPV (i.e., eran percibidos como más agradables). No obstante, la participación de personas de este grupo en nuestro estudio fue muy escasa, por lo que debería llevarse a cabo un nuevo estudio con una muestra más amplia antes de tomar este resultado como concluyente.

\subsubsection{Relacionadas con las tendencias y la implicación europea}

Resulta evidente el interés por dar continuidad a la investigación descrita en el capítulo 4 desde una perspectiva temporal, con la finalidad de confirmar la creciente tendencia de proyectos que reciben financiación europea destinados a implementar de forma real energías renovables a escala urbana.

Por otro lado, dado que el estudio se centra en los programas de financiación de ámbito europeo sería conveniente en futuros estudios ampliar el marco geográfico a zonas en las que también hay una fuerte implementación de energías renovables y de sistemas de almacenamiento de energía, como Estados Unidos, o países asiáticos como China, Japón o Corea del Sur.

Sin abandonar el enfoque geográfico, debemos tener en cuenta que los proyectos analizados fueron filtrados previamente por los programas de financiación de la Comisión Europea. Sin embargo, cada país miembro de la Unión establece también sus propios programas de inversión en I+D. En ese sentido, hay estudios que afirman que el presupuesto destinado a energías renovables de los estados miembros es aproximadamente seis veces superior al de la Comisión Europea, mientras que la tendencia a lo largo del tiempo ha sido bastante similar (Bointner et al., 2016). Por ejemplo, en un país como Alemania que no ha destacado por coordinar este tipo de proyectos (ver figura 4.5 en el capítulo 4), el Ministerio de Medio Ambiente gestiona varios proyectos de almacenamiento estacional, cuyas tecnologías se han investigado y desarrollado continuamente desde 1993 (www.saisonalspeicher.de). Además, el Ministerio Federal de Educación e Investigación y el Ministerio Federal de Economía y Energía asignan muchos recursos a proyectos de investigación y ejecución que promueven la eficiencia y la transición energética (por ejemplo, los proyectos FutureSUN o QUARREE100). Por todo ello, futuras investigaciones podrían ahondar en los programas de financiación propios de los estados miembros, ampliando así la muestra y completando el enfoque holístico de la investigación.

\subsection{Repercusión de la investigación en la sociedad y en el proceso de implantación de los sistemas de energía solar integrados}

Los principales resultados del trabajo de investigación de esta tesis doctoral pueden tener consecuencias positivas en muchos ámbitos. Por ejemplo, podemos destacar a la administración pública, así como a los agentes que intervienen en el diseño y la 
implantación de los sistemas de energía solar. Además, puede tener influencias relevantes para las propias personas que habitan en la ciudad. La Fig. 5.3 representa los posibles ámbitos de actuación relacionados con la tesis junto con los elementos en los que la investigación puede tener una repercusión más directa.

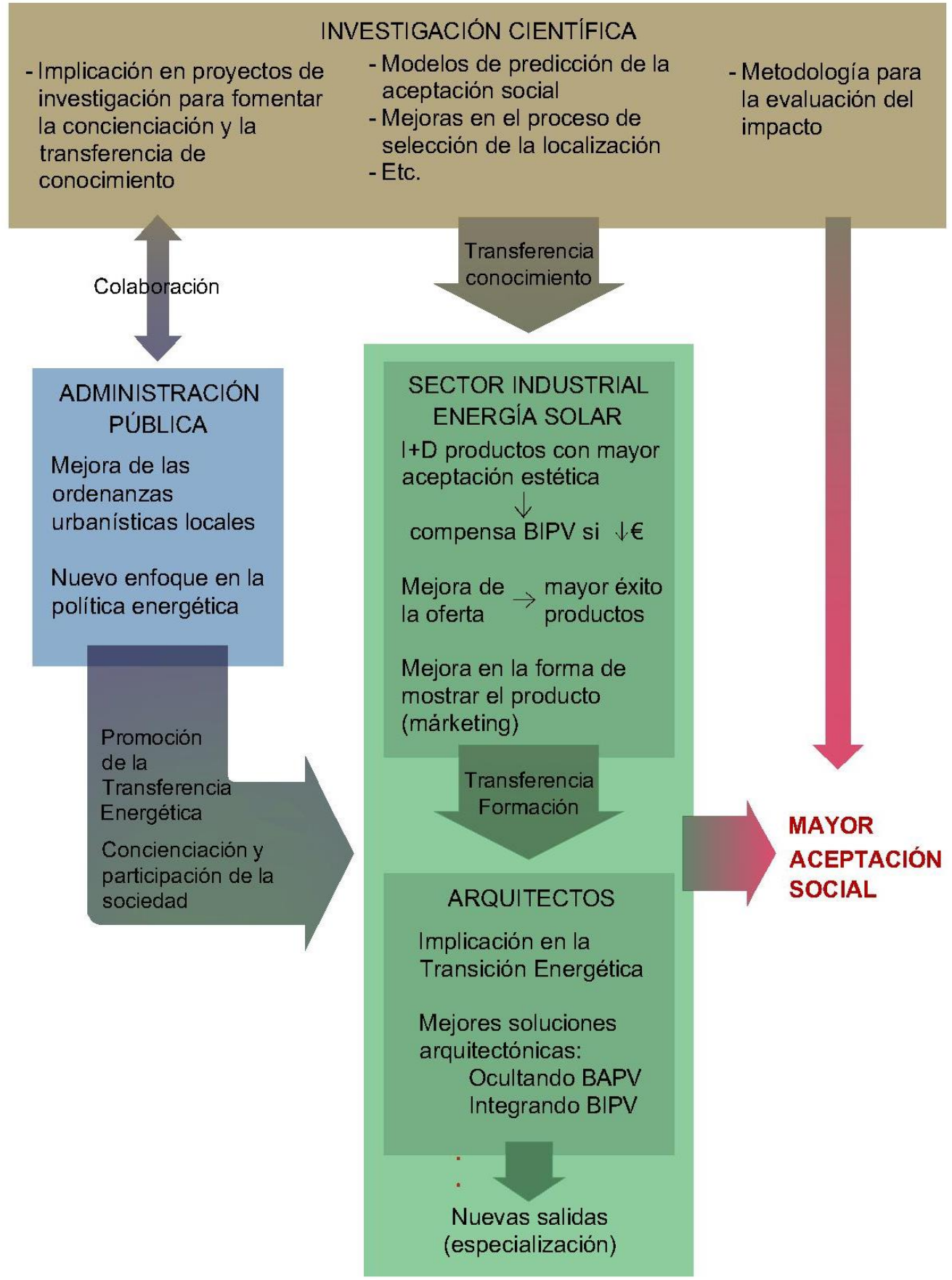

Fig. 5. 3 Representación gráfica del ámbito de actuación relacionado con la tesis. 
A nivel científico se han planteado algunas posibles líneas de investigación futuras que, con un enfoque totalmente práctico, podrían derivar en un modelo de predicción de la aceptación social para sistemas de energía solar, pero también en una metodología apropiada para la evaluación del impacto estético de las instalaciones. De esta forma, se podrían prevenir escenarios poco deseables, como los que han invadido con anterioridad nuestras ciudades, asociados por ejemplo a instalaciones de aire acondicionado o antenas de televisión.

La trasferencia del conocimiento científico al sector industrial de los SES es imprescindible con el fin de dirigir las inversiones en I+D a productos que vayan a tener una mayor aceptación estética en el mercado. En esta línea, se ha demostrado que los sistemas BIPV están mejor valorados por la sociedad que los sistemas BAPV, aunque con un margen poco amplio. Parece lógico que si se consiguiera reducir el coste de los sistemas BIPV quedaría garantizada una mayor aceptación de estos sistemas. Por lo tanto, disponer de modelos de predicción y conocer los factores más relevantes para la sociedad en la percepción estética de estas instalaciones permitirá a las empresas mejorar la oferta de sus productos, e incluso la forma en que son expuestos para su venta.

Una de las barreras identificadas para la expansión de los sistemas fotovoltaicos integrados en los edificios, conocidos como BIPV, es precisamente la reticencia de muchos arquitectos (Curtius, 2018). De hecho, muchas veces esta reticencia viene provocada por la falta de conocimiento de esta tecnología. Sería muy deseable por parte de la industria la transferencia de conocimientos, así como promover la formación específica para arquitectos y otros técnicos que puedan intervenir en el proceso de diseño y prescripción de productos en el ámbito de la construcción y rehabilitación de edificios. De esta forma, los técnicos adquirirían capacidades para diseñar mejores soluciones constructivas, incrementando el uso de estas tecnologías en la envolvente de los edificios e implicándose de forma directa en la transición energética, tan necesaria para combatir los efectos del calentamiento global. Adicionalmente, esto abre una nueva vía de especialización para el personal técnico. Para ello, resultan de gran ayuda los trabajos de investigación cuyo objetivo es precisamente esa transmisión de conocimientos al colectivo de arquitectos y técnicos que intervienen en los proyectos de integración arquitectónica (Solar Heating \& Cooling Programme, 2012).

Por su parte, las administraciones tienen un papel muy importante colaborando en proyectos de investigación que fomenten la concienciación y la participación de la sociedad en el proceso de transición energética. Igualmente, está en su mano mejorar la legislación estatal, así como las ordenanzas urbanísticas locales para favorecer la transición energética, de la que deberían ser plenos promotores ayudando al sector industrial y a los técnicos en su misión. En definitiva, administraciones públicas, sector industrial y arquitectos pueden verse beneficiados por los resultados de esta tesis doctoral y de las investigaciones futuras que puedan 
derivarse de la misma en un ámbito más aplicado, con la finalidad de generar una mayor aceptación social de la integración de sistemas solares en los edificios.

\section{REFERENCIAS}

Amado, M., Poggi, F., Amado, A.R., 2016. Energy efficient city: A model for urban planning. Sustain. Cities Soc. 26, 476-485. https://doi.org/10/ggfwtn

Amirante, R., Cassone, E., Distaso, E., Tamburrano, P., 2017. Overview on recent developments in energy storage: Mechanical, electrochemical and hydrogen technologies. Energy Convers. Manag. https://doi.org/10/drws

Arán, J., Espín, A., Aznar, F., Zamorano, M., Rodríguez, M., Ramos, A., 2008. Environmental decision-support systems for evaluating the carrying capacity of land areas: Optimal site selection for grid-connected photovoltaic power plants. Renew. Sustain. Energy Rev. https://doi.org/10/bwrg39

Azevêdo, V.W.B., Candeias, L.B., Tiba, C., 2017. Location study of solar thermal power plant in the state of Pernambuco using geoprocessing technologies and Multiple-Criteria analysis. Energies 10, 1042. https://doi.org/10/gbsk7z

Backs, R.W., da Silva, S.P., Han, K., 2005. A comparison of younger and older adults' selfassessment manikin ratings of affective pictures. Exp. Aging Res. 31, 421-440. https://doi.org/10/fhx4nx

Bao, Q., Honda, T., El Ferik, S., Shaukat, M.M., Yang, M.C., 2017. Understanding the role of visual appeal in consumer preference for residential solar panels. Renew. Energy 113, 1569-1579. https://doi.org/10/drwt

Bevk, T., Golobič, M., 2020. Contentious eye-catchers: Perceptions of landscapes changed by solar power plants in Slovenia. Renew. Energy 152, 999-1010. https://doi.org/10/drww

Bishop, I., Dartnell, P., Davie, S., Drew, J., McDonald, T., 1990. Object, environment and observer related variables in the visual effect of electricity transmission lines. Landsc. Aust.

Bishop, I.D., 1997. Testing perceived landscape colour difference using the Internet. Landsc. Urban Plan. 37, 187-196. https://doi.org/10/djhmvj

Bizzarri, G., Gillott, M., Belpoliti, V., 2011. The potential of semitransparent photovoltaic devices for architectural integration: The development of device performance and improvement of the indoor environmental quality and comfort through case-study application. Sustain. Cities Soc. 1, 178-185. https://doi.org/10/dhxxdd

Bointner, R., Pezzutto, S., Grilli, G., Sparber, W., 2016. Financing innovations for the renewable energy transition in Europe. Energies 9, 990. https://doi.org/10/f9db2q

Borgogno, E., Fabrizio, E., Chiabrando, R., 2015. Site selection of large ground-mounted photovoltaic plants: A GIS decision support system and an application to Italy. Int. J. 
Green Energy 12, 515-525. https://doi.org/10/dr7g

Bradley, M.M., Codispoti, M., Sabatinelli, D., Lang, P.J., 2001. Emotion and motivation II: sex differences in picture processing. Emotion 1, 300-319. https://doi.org/10/fpdcf2

Cannavale, A., Hörantner, M., Eperon, G.E., Snaith, H.J., Fiorito, F., Ayr, U., Martellotta, F., 2017. Building integration of semitransparent perovskite-based solar cells: Energy performance and visual comfort assessment. Appl. Energy 194, 94-107. https://doi.org/10/f96h22

Cebulla, F., Haas, J., Eichman, J., Nowak, W., Mancarella, P., 2018. How much electrical energy storage do we need? A synthesis for the U.S., Europe, and Germany. J. Clean. Prod. 181, 449-459. https://doi.org/10/gdbtvx

Cerón, I., Caamaño-Martín, E., Neila, F.J., 2013. 'State-of-the-art' of building integrated photovoltaic products. Renew. Energy 58, 127-133. https://doi.org/10/drw3

Chen, H.Q., Honda, T., Yang, M.C., 2013. Approaches for identifying consumer preferences for the design of technology products: a case study of residential solar panels. J. Mech. Des. 135, 061007. https://doi.org/10/gbdzzs

Chiabrando, R., Fabrizio, E., Garnero, G., 2011. On the applicability of the visual impact assessment OAISPP tool to photovoltaic plants. Renew. Sustain. Energy Rev. 15, 845850. https://doi.org/10/bdkjr8

Curreli, A., Serra-Coch, G., Isalgue, A., Crespo, I., Coch, H., 2016. Solar energy as a form giver for future cities. Energies 9. https://doi.org/10/f83cgv

Curtius, H.C., 2018. The adoption of building-integrated photovoltaics: barriers and facilitators. Renew. Energy. https://doi.org/10/dsft

Debije, M.G., Verbunt, P.P.C., 2012. Thirty years of luminescent solar concentrator research: solar energy for the built environment. Adv. Energy Mater. 2, 12-35. https://doi.org/10/cmfvr3

Devine-Wright, P., Batel, S., Aas, O., Sovacool, B., Labelle, M.C., Ruud, A., 2017. A conceptual framework for understanding the social acceptance of energy infrastructure: Insights from energy storage. Energy Policy 107, 27-31. https://doi.org/10/gbpts8

Eerola, T., Vuoskoski, J.K., Kautiainen, H., 2016. Being moved by unfamiliar sad music is associated with high empathy. Front. Psychol. 7, 1176. https://doi.org/10/f84bpr

EU, 2018. Horizon 2020 Challenge 10. Secure, Clean and Efficient Energy: Work Programme 2018 - 2020.

EU, 2016. Clean Energy For All Europeans, $\operatorname{COM(2016)~} 860$.

EU, 2015. Horizon 2020 Challenge 10. Secure, Clean and Efficient Energy: Work Programme 2014 - 2015. 
EU, 2014. A policy framework for climate and energy in the period from 2020 to 2030, COM(2014) 015. OPOCE.

EU, 2008. 2020 by 2020 Europe's climate change opportunity, COM(2008) 30.

EU, 2007. A European strategic energy technology plan (SET-plan) - "Towards a low carbon future." OPOCE.

Fernandez-Jimenez, L.A., Mendoza-Villena, M., Zorzano-Santamaria, P., Garcia-Garrido, E., Lara-Santillan, P., et, 2015. Site selection for new PV power plants based on their observability. Renew. Energy 78, 7-15. https://doi.org/10/f67db8

Flacke, J., de Boer, C., 2017. An interactive planning support tool for addressing social acceptance of renewable energy projects in The Netherlands. ISPRS Int. J. GeoInformation 6, 313. https://doi.org/10/gcj53f

Foulds, C., Christensen, T.H., 2016. Funding pathways to a low-carbon transition. Nat. Energy 1. https://doi.org/10/dsd8

Freitas, S., Reinhart, C., Brito, M.C., 2018. Minimizing storage needs for large scale photovoltaics in the urban environment. Sol. Energy 159, 375-389. https://doi.org/10/gcwz66

Frontini, F., Munari, M.C., Scognamiglio, A., Roecker, C., Farkas, K., Maturi, L., Zanetti, I., 2012. IEA SHC Task 41: Solar enegy systems in architecture. Integration criteria and guidelines (Part B).

García-Garrido, E., Lara-Santillán, P., Zorzano-Alba, E., Mendoza-Villena, M., ZorzanoSantamaría, P., Fernández-Jiménez, L.A., Falces, A., 2012. Visual impact assessment for small and medium size PV plants, in: Advances in Power and Energy Systems. Prague, pp. 57-61.

García, L., Hernández, J., Ayuga, F., 2006. Analysis of the materials and exterior texture of agro-industrial buildings: a photo-analytical approach to landscape integration. Landsc. Urban Plan. 74, 110-124. https://doi.org/10/d63zbq

García, L., Hernández, J., Ayuga, F., 2003. Analysis of the exterior colour of agroindustrial buildings: a computer aided approach to landscape integration. J. Environ. Manage. 69, 93-104. https://doi.org/10/b7xvc8

Gifford, R., Hine, D.W., Muller-Clemm, W., D’Arcy J Reynolds, J., Shaw, K.T., 2000. Decoding modern architecture. A lens model approach for understanding the aesthetic differences of architects and laypersons. Environ. Behav. 32, 163-187.

Gläser, J., Laudel, G., 2016. Governing science. How science policy shapes research content abstract. Eur. J. Sociol. 57, 117-168. https://doi.org/10/f8jhdc

Grühn, D., Scheibe, S., 2008. Age-related differences in valence and arousal ratings of pictures from the International Affective Picture System (IAPS): Do ratings become more extreme with age? Behav. Res. Methods 40, 512-521. https://doi.org/10/d54b5k 
Hagerhall, C.M., Purcell, T., Taylor, R., 2004. Fractal dimension of landscape silhouette outlines as a predictor of landscape preference. J. Environ. Psychol. 24, 247-255. https://doi.org/10/d7svxw

Ho, C.K., Sims, C.A., Yellowhair, J.E., Bush, E., 2015. Solar Glare Hazard Analysis Tool (SGHAT).

Huang, J., Fan, J., Furbo, S., Li, L., 2019. Solar water heating systems applied to high-rise buildings - Lessons from experiences in China. Energies 12, 1-26. https://doi.org/10/dsfr

IRENA, 2017. Electricity storage and renewables: Costs and markets to 2030, International Renewable Energy Agency. Abu Dhabi.

Johnston, D., 2007. Solar energy systems installed on Chinese-style buildings. Energy Build. 39, 385-392. https://doi.org/10/fg5t7c

Kapetanakis, I.A., Kolokotsa, D., Maria, E.A., 2014. Parametric analysis and assessment of the photovoltaics' landscape integration: Technical and legal aspects. Renew. Energy 67, 207-214. https://doi.org/10/f52cws

Kapsis, K., Athienitis, A.K., 2015. A study of the potential benefits of semi-transparent photovoltaics in commercial buildings. Sol. Energy 115, 120-132. https://doi.org/10/f7d75j

Koellner, T., de Baan, L., Beck, T., Brandão, M., Civit, B., et al., 2013. UNEP-SETAC guideline on global land use impact assessment on biodiversity and ecosystem services in LCA. Int. J. Life Cycle Assess. 18, 1188-1202. https://doi.org/10/f3p7h4

Kowalczuk, Z., Czubenko, M., 2016. Computational approaches to modeling artificial emotion - An overview of the proposed solutions. Front. Robot. Al 3, 21. https://doi.org/10/dr77

Landscape Institute, 2013. Guidelines for landscape and visual impact assessment, 3rd ed. Routledge.

Lang, P., Bradley, M., Cuthbert, B., 1997. International Affective Picture System (IAPS): Technical manual and affective ratings. NIMH Cent. Study Emot. Atten. 39-58.

Langer, K., Decker, T., Menrad, K., 2017. Public participation in wind energy projects located in Germany: Which form of participation is the key to acceptance? Renew. Energy 112, 63-73. https://doi.org/10/dsfc

Lobaccaro, G., Croce, S., Lindkvist, C., Munari, M.C., Scognamiglio, A., Dahlberg, J., Lundgren, M., Wall, M., 2019. A cross-country perspective on solar energy in urban planning: Lessons learned from international case studies. Renew. Sustain. Energy Rev. 108, 209237. https://doi.org/10/dsfs

Lovati, M., Salvalai, G., Fratus, G., Maturi, L., Albatici, R., Moser, D., 2018. New method for the early design of BIPV with electric storage: a case study in northern Italy. Sustain. Cities Soc. https://doi.org/10/dsfd 
Lu, M., Lin, A., Sun, J., 2018. The impact of photovoltaic applications on urban landscapes based on visual $Q$ methodology. Sustainability 10,1-15. https://doi.org/10/gdr52n

Luo, X., Wang, J., Dooner, M., Clarke, J., 2015. Overview of current development in electrical energy storage technologies and the application potential in power system operation. Appl. Energy 137, 511-536. https://doi.org/10/f6w3hg

Mérida-Rodríguez, M., Lobón-Martín, R., Perles-Roselló, M., 2015. The production of solar photovoltaic power and its landscape dimension, in: Renewable Energies and European Landscapes. Springer Netherlands, Dordrecht, pp. 255-277. https://doi.org/10/drxf

Moltó, J., Segarra, P., López, R., Esteller, À., Fonfría, A., Pastor, M.C., Poy, R., 2013. Adaptación española del "International Affective Picture System" (IAPS). Tercera parte. An. Psicol. 29, 965-984. https://doi.org/10/dr9t

Moseley, P., 2017. EU support for innovation and market uptake in smart buildings under the Horizon 2020 framework programme. Buildings 7, 105. https://doi.org/10/dsfg

Munari, M.C., Roecker, C., 2019. Criteria and policies to master the visual impact of solar systems in urban environments: The LESO-QSV method. Sol. Energy 184, 672-687. https://doi.org/10/dvsh

Munari, M.C., Roecker, C., 2015. Solar energy promotion \& urban context protection : LESOQSV (Quality-Site-Visibility)method, in: 31th International PLEA Conference.

Munari, M.C., Roecker, C., 2011. Urban acceptability of building integrated solar systems: LESO-QSV approach, in: 30th ISES Biennial Solar World Congress. pp. 4359-4367. https://doi.org/10.18086/swc.2011.27.10

Munari, M.C., Roecker, C., Giovanardi, A., Lundgren, M., Wall, M., 2014. IEA SHC Task 41: Designing Solar Thermal Systems for Architectural Integration, Report: IEA Task 41.A31.

Naspetti, S., Mandolesi, S., Zanoli, R., 2016. Using visual Q sorting to determine the impact of photovoltaic applications on the landscape. Land use policy 57, 564-573. https://doi.org/10/drxg

Navarro, L., de Gracia, A., Colclough, S., Browne, M., McCormack, S.J., et al., 2016. Thermal energy storage in building integrated thermal systems: A review. Part 1. active storage systems. Renew. Energy. https://doi.org/10/drxh

Navarro, L., de Gracia, A., Niall, D., Castell, A., Browne, M., et al., 2015. Thermal energy storage in building integrated thermal systems: A review. Part 2. Integration as passive system. Renew. Energy. https://doi.org/10/drxj

Nohl, W., 2001. Sustainable landscape use and aesthetic perception - preliminary reflections on future landscape aesthetics. Landsc. Urban Plan. 54, 223-237. https://doi.org/10/fh2xh2

Olivieri, L., Frontini, F., Polo-López, C., Pahud, D., Caamaño-Martín, E., 2015. G-value indoor 
characterization of semi-transparent photovoltaic elements for building integration: New equipment and methodology. Energy Build. 101, 84-94. https://doi.org/10/dvsg

Perea-Moreno, M.-A., Hernandez-Escobedo, Q., Perea-Moreno, A.-J., 2018. Renewable energy in urban areas: Worldwide research trends. Energies 11, 577. https://doi.org/10/gdr9rv

Radmehr, M., Willis, K., Kenechi, U.E., 2014. A framework for evaluating WTP for BIPV in residential housing design in developing countries: A case study of North Cyprus. Energy Policy 70, 207-216. https://doi.org/10/drxv

Rae, C., Bradley, F., 2012. Energy autonomy in sustainable communities - A review of key issues. Renew. Sustain. Energy Rev. 16, 6497-6506. https://doi.org/10/F4JWNQ

Reinhart, C.F., Cerezo, C., 2016. Urban building energy modeling - A review of a nascent field. Build. Environ. 97, 196-202. https://doi.org/10/F792M6

Rose, T., Wollert, A., 2015. The dark side of photovoltaic - 3D simulation of glare assessing risk and discomfort. Environ. Impact Assess. Rev. 52, 24-30. https://doi.org/10/f664v6

Sánchez-Lozano, J.M., García-Cascales, M.S., Lamata, M.T., 2016. Comparative TOPSISELECTRE TRI methods for optimal sites for photovoltaic solar farms. Case study in Spain. J. Clean. Prod. 127, 387-398. https://doi.org/10/f8qznn

Sánchez-Pantoja, N., Vidal, R., Pastor, M.C., 2018a. Aesthetic impact of solar energy systems. Renew. Sustain. Energy Rev. 98, 227-238. https://doi.org/10/gfqh7s

Sánchez-Pantoja, N., Vidal, R., Pastor, M.C., 2018b. Aesthetic perception of photovoltaic integration within new proposals for ecological architecture. Sustain. Cities Soc. 39, 203-214. https://doi.org/10/gdr37n

Schindler, I., Hosoya, G., Menninghaus, W., Beermann, U., Wagner, V., Eid, M., Scherer, K.R., 2017. Measuring aesthetic emotions: $A$ review of the literature and a new assessment tool. PLoS One 12. https://doi.org/10/gbgrn5

Scognamiglio, A., 2016. "Photovoltaic landscapes": Design and assessment. A critical review for a new transdisciplinary design vision. Renew. Sustain. Energy Rev. 55, 629-661. https://doi.org/10/drxw

Silvia, P.J., Fayn, K., Nusbaum, E.C., Beaty, R.E., 2015. Openness to experience and awe in response to nature and music: Personality and profound aesthetic experiences. Psychol. Aesthetics, Creat. Arts 9, 376-384. https://doi.org/10/dr8f

Skandalos, N., Karamanis, D., Peng, J., Yang, H., 2018. Overall energy assessment and integration optimization process of semitransparent PV glazing technologies. Prog. Photovoltaics Res. Appl. 26, 473-490. https://doi.org/10/gdswrt

Solar Heating \& Cooling Programme, 2012. Report T.41.A.2: Solar energy systems in architecture. 
Spurling, N., Mcmeekin, A., Shove, E., Southerton, D., Welch, D., 2013. Interventions in practice : re-framing policy approaches to consumer behaviour.

Stamps, A.E., 2002. Fractals, skylines, nature and beauty. Landsc. Urban Plan. 60, 163-184. https://doi.org/10/fk35q3

Strazzera, E., Statzu, V., 2017. Fostering photovoltaic technologies in Mediterranean cities: Consumers' demand and social acceptance. Renew. Energy 102, 361-371. https://doi.org/10/f9hmhh

Suuronen, A., Lensu, A., Kuitunen, M., Andrade-Alvear, R., Celis, N.G., et al., 2017. Optimization of photovoltaic solar power plant locations in northern Chile. Environ. Earth Sci. 76, 824. https://doi.org/10/gctbzr

Tolli, M., Recanatesi, F., Piccinno, M., Leone, A., 2016. The assessment of aesthetic and perceptual aspects within environmental impact assessment of renewable energy projects in Italy. Environ. Impact Assess. Rev. 57, 10-17. https://doi.org/10/f8gp63

Torres-Sibille, A.C., Cloquell-Ballester, Vicente-A., Cloquell-Ballester, Víctor-A., Artacho, M.A., 2009. Aesthetic impact assessment of solar power plants: An objective and a subjective approach. Renew. Sustain. Energy Rev. 13, 986-999. https://doi.org/10/c4xh7r

Tudor, C., 2014. An approach to landscape character assessment, Natural England. Natural England.

Vaughan, J., Ostwald, M.J., 2017. The comparative numerical analysis of nature and architecture: A new framework. Int. J. Des. Nat. Ecodynamics 12, 156-166. https://doi.org/10/dr8j

von Möllendorff, C., Welsch, H., 2017. Measuring renewable energy externalities: evidence from subjective well-being data. Land Econ. 93, 109-126. https://doi.org/10/dr8k

Vossen, F.M., Aarts, M.P.J., Debije, M.G., 2016. Visual performance of red luminescent solar concentrating windows in an office environment. Energy Build. 113, 123-132. https://doi.org/10/f8djsx

Werner, S., 2017. International review of district heating and cooling. Energy 137, 617-631. https://doi.org/10/gcjjnc

Wüstenhagen, R., Wolsink, M., Bürer, M.J., 2007. Social acceptance of renewable energy innovation: An introduction to the concept. Energy Policy 35, 2683-2691. https://doi.org/10/ct59cw

Xiang, C., Szybinska Matusiak, B., 2019. Facade integrated photovoltaic, state of the art of experimental methodology, in: 1st Nordic Conference on Zero Emission and Plus Energy Buildings. pp. 1-8. https://doi.org/10/dsfn

Xu, R., Wittkopf, S., Roeske, C., 2017. Quantitative evaluation of BIPV visual impact in building retrofits using saliency models. Energies 10, 668. https://doi.org/10/dr8m 
Yang, R.J., Zou, P.X.W., 2016. Building integrated photovoltaics (BIPV): costs, benefits, risks, barriers and improvement strategy. Int. J. Constr. Manag. 16, 39-53. https://doi.org/10/drx5

Zoellner, J., Schweizer-Ries, P., Wemheuer, C., 2008. Public acceptance of renewable energies: Results from case studies in Germany. Energy Policy 36, 4136-4141. https://doi.org/10/fbcz5t 


\section{CAPÍTULO 6. CONCLUSIONES}

En la presente tesis doctoral se ha investigado un tema de reciente interés en la literatura científica como es la percepción estética de los sistemas de energía solar y su impacto visual en el entorno urbano que rodea nuestra actividad diaria en la ciudad. Es evidente que la implantación de estas nuevas tecnologías en los edificios está causando un impacto en la sociedad, aunque hasta el momento no se están realizando grandes esfuerzos para mitigarlo y la literatura científica destinada a su evaluación es escasa. Precisamente, este trabajo pretende servir como punto de partida para investigaciones futuras en este ámbito de estudio, y cumple el propósito principal de establecer un marco conceptual teórico de la percepción estética de los nuevos sistemas de energías renovables que sirva para desarrollar recursos que incrementen la aceptación social y favorezcan así su uso extensivo. Las principales conclusiones de la presente tesis doctoral se presentan en el primer apartado, seguidas por la validación de las hipótesis y el cumplimiento de los objetivos.

\subsection{Principales resultados}

En el segundo capítulo, correspondiente con el artículo (Sánchez-Pantoja et al., 2018a), se concluye:

1. Falta de consenso en la aplicación de factores objetivos y metodologías destinadas a la evaluación del impacto estético.

2. Falta de estudios que relacionen factores objetivos y evaluación subjetiva.

3. Clasificación de los factores objetivos en función de su complejidad e interdependencias.

4. Determinación de los factores objetivos más influyentes: visibilidad y grado de integración.

5. Propuesta de marco metodológico cualitativo. El impacto estético se divide en tres sub-impactos: el uso del suelo, el propio sistema de energía solar (SES) y el deslumbramiento.

6. A efectos prácticos, y asumiendo la limitación de que este marco está basado en la literatura existente, podemos afirmar que los arquitectos e ingenieros responsables de los proyectos que integren sistemas de energía solar deberían prestar la máxima atención a la visibilidad y al grado de integración en el proceso de diseño para minimizar el impacto.

Del capítulo 3, en el que se presenta el artículo (Sánchez-Pantoja et al., 2018b), cabe destacar:

1. Por primera vez, se utilizan datos recogidos de los propios observadores de la instalación solar.

2. Realización de encuesta de valoración subjetiva. Se evaluaron 20 prototipos de vivienda solar que incluían sistemas BIPV y BAPV, y se consideraron 3 categorías 
en función del grado de apreciación de la instalación por parte del observador a nivel de calle.

3. Se observó una percepción general positiva (agrado) y un nivel de activación emocional medio.

4. A mayor apreciación de la instalación por parte del observador, menor puntuación de la valencia hedónica (agrado).

5. Se confirmó para los sistemas BIPV una mayor puntuación que para los sistemas BAPV, tanto en valencia hedónica (agrado) como en el grado de activación (intensidad emocional).

6. Se evidenció una mayor aceptación de los sistemas solares por parte del sector más joven de la muestra.

En el capítulo 4, que corresponde al artículo pendiente de aceptación para ser publicado, se concluye:

1. Desde el año 2000 , apenas un $0,1 \%$ de los proyectos financiados por programas europeos se han destinado a la instalación real de energías renovables a escala urbana. Sin embargo, en los últimos años ha habido una clara tendencia al alza de este porcentaje.

2. La energía renovable más comúnmente utilizada ha sido la solar y en especial la tecnología fotovoltaica; mientras que para el almacenamiento de energía el sistema más utilizado son las baterías de litio.

3. A nivel geográfico, las entidades de los países del suroeste de Europa muestran en general una mayor participación en este tipo de proyectos financiados por la UE. Destacan sobre todo España y Bélgica, seguidos de Italia y Alemania.

4. La mayoría de los proyectos seleccionados para este estudio pertenecían al programa H2020. Aunque este programa nunca ha considerado un tema clave el impacto estético de las energías renovables, desde 2014 ha comenzado a aparecer en las convocatorias la palabra "estética".

5. Sería recomendable que las convocatorias de financiación empezaran a considerar las tecnologías como productos y componentes básicos del trabajo y la vida cotidiana, y no sólo como un medio de intervención para promover energías más limpias y renovables, y así ayudarnos a preservar el planeta.

Finalmente, del capítulo 5 dedicado a resumir y discutir los resultados de los capítulos anteriores, cabe destacar los siguientes puntos:

1. Esta tesis doctoral supone un gran avance en el marco conceptual que envuelve el impacto estético de los SES.

2. La definición de los factores objetivos más influyentes (visibilidad y grado de integración) en el capítulo 2 se ve corroborada por los resultados obtenidos en el capítulo 3. En consecuencia, en el capítulo 4 no se tienen en consideración para el impacto estético aquellas instalaciones no visibles por no causar un impacto estético en la sociedad. 
3. En base a los resultados de los capítulos 2 y 3, los proyectos de integración de energías renovables a escala urbana deberían prestar especial atención a la localización de las instalaciones, y tomar como referencia los sistemas BIPV que gozan de una mayor aceptación por parte de los ciudadanos.

4. Se han encontrado varios estudios posteriores a los artículos de los capítulos 2 y 3 que coinciden en los factores visuales considerados más influyentes.

5. La mayor limitación de la tesis doctoral ha sido la escasa literatura previa relacionada.

6. La línea de investigación futura más sugerente es la verificación del marco metodológico cualitativo propuesto y el desarrollo de un método de predicción de la aceptación estética social de los SES.

7. La transición energética requiere un cambio en la conciencia, los hábitos y el comportamiento de la sociedad y, para ello, es necesaria la participación ciudadana en todo el proceso.

8. Los resultados de esta investigación podrían tener una importante repercusión en el proceso de implantación de los sistemas de energía solar integrados, puesto que sirven de ayuda a administraciones públicas, sector industrial y arquitectos para mejorar la aceptación social de los SES integrados en la ciudad.

\subsection{Validación de las hipótesis}

La aplicación de los diferentes métodos utilizados a lo largo de la investigación ha permitido validar las hipótesis y las tendencias planteadas en el capítulo primero. A continuación se justifica la validación de dichas hipótesis que, debido a la perspectiva social que tiene la investigación, ha consistido en algunos casos en sanear la información previa relacionada.

Hipótesis 1: necesidad de revisar los factores objetivos y los criterios de evaluación ante la falta de consenso científico.

Se llevó a cabo una revisión de la literatura relacionada con los factores objetivos que influyen en la percepción estética de los SES en la que se identificaron un total de 15 factores. Sin embargo, la mayoría de ellos aparecían en muy pocos estudios y solo 4 mostraron tener una continuidad relevante en la literatura. Un análisis más detallado permitió proponer, a partir de los estudios previos, una clasificación de los factores en función de su complejidad y de la dependencia existente entre ellos. Así, un primer grupo lo formarían aquellos factores considerados simples e independientes de otros (como el color o la textura), y otro grupo lo formarían aquellos considerados complejos y dependientes de otros parámetros. Como resultado de este análisis se pudieron determinar como factores objetivos más influyentes, que coinciden precisamente con los factores considerados complejos y dependientes, la visibilidad y el grado de integración. 
Posteriormente se realizó una revisión de la literatura sobre métodos que relacionan los factores objetivos con la percepción subjetiva del impacto estético de los SES identificando 4 potenciales metodologías. Un análisis más detallado de los factores y los métodos utilizados en la literatura dieron como resultado, tras un profundo ejercicio de síntesis, la propuesta del marco metodológico cualitativo que sirva de punto de partida para futuras investigaciones sobre el impacto estético de los sistemas de energía solar.

Hipótesis 2: el uso de energías renovables en los edificios se percibe positivamente, además de como beneficio medioambiental, por su estética.

Para evaluar la percepción estética de los sistemas de energía solar utilizados en los edificios se utilizó como escenario de muestra los prototipos de vivienda solar del concurso internacional Solar Decathlon Europe 2014 celebrado en Versalles. Con el fin de recoger los datos directamente de los ciudadanos, se diseñó una encuesta en la que se evaluaron 20 prototipos que ofrecían una variada muestra de tecnologías, incluyendo sistemas BIPV y BAPV. Durante las dos semanas de concurso se obtuvo una primera muestra, de forma presencial, cuyo análisis estadístico sirvió para validar posteriormente una muestra mayor obtenida mediante encuestas "online" utilizando fotografías. La encuesta se diseñó con una primera parte destinada a recoger datos sociodemográficos de las personas encuestadas, y una segunda parte destinada a evaluar los sentimientos del observador cuando ve el prototipo utilizando el método SAM. EI SAM es un método no verbal que permitió, mediante una escala pictórica, evaluar las reacciones emocionales en base a dos dimensiones: la valencia hedónica (agrado-desagrado) y la activación emocional (grado de excitación). El análisis estadístico de los datos obtenidos permitió corroborar una percepción general positiva de los SES.

Hipótesis 3: IOS SES utilizados en los edificios tienen una mayor aceptación entre la población más joven, generalmente más receptivos y abiertos a nuevas tecnologías.

De forma similar a la segunda hipótesis, el análisis estadístico de los datos obtenidos sobre los parámetros sociodemográficos demostró una influencia clara de la edad en el grado de aceptación. El grupo más joven otorgó generalmente valores más altos de intensidad emocional y, a menor edad del encuestado, mayor aceptación para los prototipos con sistemas BAPV que ofrecen una estética más industrial. En consecuencia, podemos afirmar que la gente mayor penaliza en mayor medida la falta de una cuidada integración del sistema en la envolvente del edificio.

Hipótesis 4: mayor aceptación de los sistemas BIPV sobre los BAPV.

También con el análisis estadístico de los datos obtenidos con la encuesta se pudo comprobar una mayor aceptación de los sistemas BIPV frente a los sistemas BAPV, que justificaría la tolerancia en el incremento de recursos económicos y técnicos necesarios en la fase de diseño y construcción de la instalación solar. Sin embargo, 
debe tenerse en cuenta que la diferencia en la valoración de las dos tecnologías no es muy grande y podría verse reducida si el observador percibe que la inversión económica y el desarrollo tecnológico necesario para instalar el sistema BIPV es muy alto.

Hipótesis 5: existe una tendencia creciente de proyectos de implementación efectiva de energías renovables a escala urbana como reflejo de los compromisos y las estrategias energéticas establecidas en los últimos años por la Unión Europea (EU, 2015b, 2015a).

En este estudio se llevó a cabo una revisión sistemática de los proyectos de los 5 programas de financiación europeos más relevantes en relación con la promoción de energías renovables y la mitigación del cambio climático. En una primera fase se realizó una intensa búsqueda que incluyó un total de casi 14000 proyectos, a los que se aplicó una serie de filtros en 3 pasos consecutivos con el fin de seleccionar aquellos que estaban realmente destinados a la implantación de instalaciones de energía renovable a escala urbana. El análisis temporal realizado con los 63 proyectos que superaron el segundo filtrado por su relación con la implementación de energías renovables en la ciudad permitió identificar 3 etapas claramente diferenciables. La primera etapa, que comprende la época entre los años 2000 y 2006, únicamente cuenta con 3 o 4 proyectos anuales. En la segunda etapa, comprendida entre 2007 y 2013, un importante número de proyectos superaron el segundo filtro como consecuencia del impulso dado a la política climática europea en 2007, pero la mayoría de estos proyectos resultaron estar enmarcados en intervenciones políticas, en lugar de seguir un enfoque práctico de implementación real de tecnologías. La tercera etapa, a partir del año 2013, mostró un crecimiento continuo de proyectos destinados a la implementación real de energías renovables. En este periodo también fueron clave los años 2014 y 2016, con nuevos compromisos y estrategias energéticas establecidas por la Comisión Europea. Este análisis temporal permitió confirmar la existencia de una tendencia real a financiar proyectos innovadores que impliquen una implementación efectiva de sistemas de energías renovables a escala urbana. Sin embargo, dado que esta revisión se llevó a cabo a finales de 2018, es de esperar que esta tendencia siga en aumento si se incluyen los proyectos de convocatorias posteriores.

Hipótesis 6: escasa consideración del impacto estético en los proyectos europeos de energías renovables en entornos urbanos, pero con una tendencia al alza en los próximos años.

El análisis detallado de los proyectos revisados mostró una falta total de concienciación respecto al impacto estético producido por la integración de energías renovables. De hecho, en ningún proyecto se planteó una metodología que permitiera realizar una evaluación del este impacto. Además, en las entrevistas llevadas a cabo con personal técnico participante en estos proyectos se detectaron 
reacciones de sorpresa al ser preguntados al respecto. Por todo ello, no se ha podido ratificar una tendencia al alza como se esperaba.

\subsection{Cumplimiento de los objetivos}

El importante componente social del tema y la escasez de literatura relacionada fueron determinantes para que la investigación se encaminara hacia unos objetivos concretos que resultan imprescindibles para poder avanzar a nivel conceptual. De esta forma, se han alcanzado resultados muy significativos, que abren diferentes líneas de investigación futuras y que pueden ser muy relevantes para el sector industrial, para los técnicos (especialmente arquitectos como principal agente diseñador de edificios), e incluso para las administraciones públicas, en los procesos de implantación de energías renovables en la ciudad y su aceptación social.

Los objetivos generales de la tesis doctoral quedan justificados de la manera que se detalla a continuación:

Objetivo 1: Definir los factores objetivos más influyentes en el impacto estético de los sistemas de energía solar.

Se han definido como factores objetivos más influyentes la visibilidad y el grado de integración. Estos 2 factores se han descrito como complejos y dependientes de otros factores simples como el color, la forma o la textura.

Objetivo 2: Proponer un marco metodológico cualitativo que sirva de base a futuras investigaciones.

Se ha propuesto un marco metodológico cualitativo en el que el impacto estético se divide en tres sub-impactos: el uso del suelo, el propio sistema de energía solar (SES) y el deslumbramiento. Para el caso específico de los sistemas BIPV, donde el propio sistema es un elemento constructivo que forma parte de la envolvente del edificio, el sub-impacto uso del suelo sería despreciable.

Objetivo 3: Conocer si el impacto que producen los sistemas de energía solar utilizados en los edificios es positivo o negativo.

Se ha confirmado que hay una percepción general positiva (agrado) de los sistemas de energía solar utilizados en los edificios, puesto que el $80 \%$ de los prototipos se puntuaron por encima del 4 en una escala del 1 al 7.

Objetivo 4: Demostrar la mayor aceptación de los sistemas BIPV sobre los BAPV.

En la comparación entre los sistemas BAPV y los BIPV -que requieren una mayor atención en la fase de diseño, así como una mayor inversión económica inicial-, se pudo comprobar que los segundos obtuvieron una mayor puntuación tanto en valencia hedónica (agrado) como en el grado de activación (intensidad emocional). 
Objetivo 5: Identificar parámetros sociodemográficos influyentes en la percepción estética.

El análisis de los factores sociodemográficos concluyó que la edad es el único parámetro que influyó claramente en la valoración, siendo los más jóvenes los que otorgan valores más altos de la intensidad emocional y, a menor edad del encuestado, mayor aceptación para los prototipos con sistemas BAPV que ofrecen una estética más industrial.

Aunque la relación de la formación de los encuestados con la arquitectura y el tamaño del núcleo urbano de residencia son dos parámetros que mostraron una cierta influencia en las valoraciones, la muestra no fue suficientemente representativa en estos parámetros para considerar los resultados como concluyentes.

Objetivo 6: Cuantificar los proyectos financiados con fondos europeos que llevan a cabo la implementación real de energías renovables en un entorno urbano.

La revisión de los 13989 proyectos de los 5 programas de financiación europea más relevantes en relación con la promoción de energías renovables y la mitigación del cambio climático permitió identificar un total de 16 proyectos destinados a implementar de forma real instalaciones de energías renovables a escala urbana. Esto supone aproximadamente un $0,1 \%$.

Objetivo 7: Definir el grado de implicación de estos proyectos respecto al impacto estético que producen en la ciudad.

La investigación reveló un nulo grado de preocupación por el impacto estético de los proyectos de energías renovables en entornos urbanos y no se encontraron proyectos que incluyeran metodologías que permitieran su evaluación.

\section{REFERENCIAS}

Sánchez-Pantoja, N., Vidal, R., Pastor, M.C., 2018a. Aesthetic impact of solar energy systems. Renew. Sustain. Energy Rev. 98, 227-238. https://doi.org/10/gfqh7s

Sánchez-Pantoja, N., Vidal, R., Pastor, M.C., 2018b. Aesthetic perception of photovoltaic integration within new proposals for ecological architecture. Sustain. Cities Soc. 39, 203-214. https://doi.org/10/gdr37n 


\section{ChAPTER 7. CONCLUSIONS}

This thesis focuses on a topic of recent interest in the scientific literature such as the aesthetic perception of solar energy systems and their visual impact on the urban environment that surrounds our daily activity in the city. Even though the implementation of these new technologies into buildings has an obvious impact on society, no great efforts have been made so far to mitigate this impact, and literature aimed to assess it is rather scarce. Therefore, this work aims to be a starting point for further research in this field of knowledge, and it fulfils the main goal of establishing a theoretical conceptual framework for the aesthetic perception of new renewable energy systems. This framework might serve to develop resources that will increase social acceptance, thus encouraging their extensive use. The main conclusions of this dissertation are showed in the first section, followed by the validation of the hypotheses and the fulfilment of the objectives.

\subsection{Main results}

The second chapter, corresponding to paper (Sánchez-Pantoja et al., 2018a), concludes:

1. Lack of consensus on the application of objective factors and methods for assessing the aesthetic impact.

2. Lack of studies linking objective factors to subjective evaluation.

3. Classification of objective factors according to their complexity and interdependencies.

4. Determination of the most influential objective factors: visibility and degree of integration.

5. Proposal for a qualitative methodological framework. The aesthetic impact is divided into three sub-impacts: land use, the solar energy system itself and glare.

6. For practical purposes, and assuming the limitation that this framework is based on existing literature, we can affirm that architects and engineers responsible for projects integrating solar energy systems should pay maximum attention to the visibility and degree of integration in the design process of a solar energy system to minimize impact.

From chapter 3, which presents the paper (Sánchez-Pantoja et al., 2018b), it is worth noting:

1. For the first time, data collected from the solar facility's own observers are used.

2. A subjective assessment survey. A total of 20 prototypes of solar housing including BIPV and BAPV systems were evaluated, and 3 categories were considered according to the degree of appreciation of the installation by the observer at street level. 
3. An overall positive perception (pleasantness) and an average level of emotional activation was observed.

4. The higher the observer's appreciation of the facility, the lower the hedonic valence score (pleasantness).

5. A higher score was confirmed for BIPV systems than for BAPV systems, both in hedonic valence (pleasantness) and in the degree of activation (emotional intensity).

6. There was a greater acceptance of solar systems by the younger sector of the sample.

Chapter 4, which corresponds to the article pending acceptance for publication, concludes:

1. Since 2000 , only $0.1 \%$ of the projects financed by European programmes have been aimed to the actual installation of renewable energies on an urban scale. However, in recent years there has been a growing trend in this percentage.

2. The most used renewable energy has been solar and especially photovoltaic technology; while for energy storage, the most commonly used system is lithium batteries.

3. At a geographical level, entities from South-Western European countries generally show a higher participation in this type of EU-funded projects. Spain and Belgium stand out, followed by Italy and Germany.

4. Most of the projects selected for this study belonged to the H2O2O programme. Although this programme has never considered the aesthetic impact of renewable energies as a key issue, since 2014 the word "aesthetic" has started to appear in the calls for proposals.

5. It would be advisable that the calls for funding start to consider technologies as products and basic components of work and daily life, and not only as a mean of intervention to promote cleaner and renewable energies that help us to preserve the planet.

Finally, from chapter 5 aimed to summarizing and discussing the results of the previous chapters, the following points are worth noting:

1. This doctoral thesis represents a major advance in the conceptual framework involving the aesthetic impact of the SES.

2. The definition of the most influential objective factors (visibility and degree of integration) in Chapter 2 is corroborated by the results obtained in Chapter 3. Consequently, in Chapter 4, installations that are not visible because they do not have an aesthetic impact on society are not taken into consideration for the aesthetic impact.

3. Based on the results of chapters 2 and 3, projects for the integration of renewable energies on an urban scale should pay special attention to the 
location of the installations, and take as a reference the BIPV systems that are most accepted by the citizens.

4. Several studies have been found subsequent to the articles in chapters 2 and 3 that agree on the visual factors considered most influential.

5. The greatest limitation of the doctoral thesis has been the scarce related previous literature.

6. The most suggestive line of future research is the verification of the proposed qualitative methodological framework and the development of a method for predicting the social aesthetic acceptance of SES.

7. The energy transition requires a change in society's awareness, habits and behaviour and, for this, citizen participation is necessary throughout the whole process.

8. The results of this research could have an important impact on the implementation process of integrated solar energy systems, as they help public administrations, industry and architects to improve the social acceptance of integrated SES in the city.

\subsection{Validation of the hypotheses}

The application of the different methods used throughout the research has made it possible to validate the hypotheses and trends set out in the first chapter. Next, the validation of these hypotheses is justified, which, due to the social perspective of the research, has consisted in some cases of cleaning up the related previous information.

Hypothesis 1: Need to review the objective factors and evaluation criteria in the absence of scientific consensus.

A review of the literature related to the objective factors influencing the aesthetic perception of SES was carried out, in which a total of 15 factors were identified. However, most of them appeared in very few studies and only 4 showed relevant continuity in the literature. A more detailed analysis made it possible to propose, on the basis of the previous studies, a classification of the factors according to their complexity and the dependence existing between them. Thus, a first group would be formed by those factors considered simple and independent from others (such as colour or texture), and another group would be formed by those considered complex and dependent on other parameters. As a result of this analysis, visibility and the degree of integration were determined as the most influential objective factors, which coincide precisely with the factors considered complex and dependent.

Subsequently, a review of the literature on methods that relate objective factors to the subjective perception of the aesthetic impact of SES was carried out, identifying 4 potential methodologies. A more detailed analysis of the factors and methods used in the literature resulted, after a thorough synthesis exercise, in the proposal of the 
qualitative methodological framework to serve as a starting point for future research on the aesthetic impact of solar energy systems.

Hypothesis 2: The use of renewable energies in buildings is perceived positively, not only as an environmental benefit, but also as aesthetic.

Solar housing prototypes of the international contest Solar Decathlon Europe 2014 held in Versailles were used as a sample scenario to assess aesthetic perception of SES used in buildings. In order to collect data directly from citizens, a survey was designed in which 20 prototypes offering a wide variety of technologies were assessed, including BIPV and BAPV systems. During the two weeks of the competition a first sample was obtained, in person, whose statistical analysis served to later validate a larger sample obtained through "online" surveys using photographs. The survey was designed with a first part aimed at collecting sociodemographic data from the surveyed people, and a second part aimed at evaluating feelings of the observers when viewing the prototypes and using the SAM method. SAM is a non-verbal method that allowed, by means of a pictorial scale, to assess emotional reactions based on two dimensions: the hedonic valence (pleasantness - displeasure) and the emotional activation (degree of excitement). The statistical analysis of the data obtained made it possible to corroborate a positive general perception of the SES.

Hypothesis 3: SES used in buildings are more widely accepted by the younger population, who are generally more receptive and open-minded to new technologies.

Similar to the second hypothesis, statistical analysis of the data obtained on sociodemographic parameters showed a clear influence of age on the degree of acceptance. The younger group generally gave higher values of emotional intensity and, the younger the respondent, the greater acceptance for prototypes with BAPV systems that offer a more industrial aesthetic. As a result, we can say that older people penalize the lack of careful integration of the system into the building envelope to a greater extent.

Hypothesis 4: Greater acceptance of BIPV systems over BAPV.

Also with the statistical analysis of the data obtained from the survey it was possible to verify a greater acceptance of the BIPV systems compared to the BAPV systems, which would justify the tolerance in the increase of economic and technical resources necessary in the design and construction phase of the solar installation. However, it should be borne in mind that the difference in the assessment of the two technologies is not very great and could be reduced if the observer perceives that the economic investment and technological development required to install the BIPV system is very high.

Hypothesis 5: There is a growing trend of projects for the effective implementation of renewable energies on an urban scale as a reflection of the commitments and 
energy strategies established in recent years by the European Union (EU, 2015b, 2015a).

In this study a systematic review of projects from the 5 most relevant European funding programmes in relation to the promotion of renewable energies and climate change mitigation was carried out. In a first phase, an intensive search was carried out that included a total of almost 14,000 projects, to which a series of filters were applied in 3 consecutive steps in order to select those that were really intended for the implementation of renewable energy facilities on an urban scale. The temporal analysis carried out with the 63 projects that passed the second filtering due to their relationship with the implementation of renewable energies in the city allowed the identification of 3 clearly differentiable steps. The first stage, which covers the period between 2000 and 2006, has only 3 or 4 projects per year. In the second stage, between 2007 and 2013, a significant number of projects passed the second filter as a result of the stimulus given to European climate policy in 2007 , but the majority of these projects turned out to be framed in political interventions, rather than following a practical approach to the actual implementation of technologies. The third stage, from 2013, showed a continuous growth of projects aimed at the actual implementation of renewable energies. The years 2014 and 2016 were also key in this period, with new commitments and energy strategies established by the European Commission. This temporal analysis allowed to confirm the existence of a real trend to finance innovative projects that involve an effective implementation of renewable energy systems on an urban scale. However, given that this review was carried out at the end of 2018, it is expected that this trend will continue to increase if projects from subsequent calls are included.

Hypothesis 6: Scant regard of the aesthetic impact on European renewable energy projects in urban environments, but with an ever-growing trend in the coming years.

The in-depth analysis of the projects reviewed showed a total lack of awareness of the aesthetic impact produced by the integration of renewable energies. In fact, none of the projects proposed a methodology to assess this impact. In addition, in the interviews carried out with technical personnel participating in these projects, surprise reactions were detected when asked about this. For all these reasons, it was not possible to ratify the expected growing trend.

\subsection{Fulfilment of objectives}

The important social component of the topic and the scarcity of related literature were determining factors in the fact that the research was directed towards specific objectives that are essential to advance at a conceptual level. In this way, highly significant results have been achieved, which open up different lines of future research and which may be very relevant for the industrial sector, for technicians (especially architects as the main designer of buildings), and even for public 
administrations, in the processes of implementation of renewable energies in the city and their social acceptance.

The general objectives of the doctoral thesis are justified as follows:

Objective 1: to define the objective factors most influencing the aesthetic impact of solar energy systems.

Visibility and degree of integration have been defined as the most influential objective factors. These two factors have been described as complex and dependent on other simple factors such as color, shape, or texture.

Objective 2: to propose a qualitative methodological system to serve as a basis for further research.

A qualitative methodological framework has been proposed in which the aesthetic impact is divided in three sub-impacts: land use, the solar energy system itself (SES) and glare. In the specific case of BIPV systems, where the system itself is a construction element that forms part of the building envelope, the sub-impact of land use would be negligible.

Objective 3: to know if the impact produced by the solar energy systems used in the buildings is positive or negative.

An overall positive perception (pleasure) of SES used in buildings has been confirmed, with $80 \%$ of the prototypes scoring above 4 on a scale of 1 to 7 .

Objective 4: demonstrate greater acceptance of BIPV systems over BAPV.

In the comparison between BAPV and BIPV systems - which require greater attention in the design phase, as well as greater initial economic investment- it was found that the latter scored higher in both hedonic valence (liking) and degree of activation (emotional intensity).

Objective 5: to identify sociodemographic parameters that influence aesthetic perception.

The analysis of socio-demographic factors concluded that age is the only parameter that clearly influenced the assessment, with the younger people giving higher values of emotional intensity and, the younger the respondent, the greater the acceptance of prototypes with BAPV systems that offer a more industrial aesthetic.

Although the relationship of the training of those surveyed with the architecture and the size of the urban area of residence are two parameters that showed a certain influence in the assessments, the sample was not sufficiently representative in these parameters to consider the results as conclusive. 
Objective 6: Quantify the projects financed with European funds that carry out the real implementation of renewable energies in an urban environment.

The review of the 13989 projects selected from the 5 most relevant European funding programmes in relation to the promotion of renewable energies and the mitigation of climate change allowed the identification of a total of 16 projects aimed at the real implementation of renewable energy installations on an urban scale. This represents approximately $0.1 \%$.

Objective 7: to define the degree of involvement of these projects with respect to the aesthetic impact they produce in the city.

The research revealed a lack of concern about the aesthetic impact of renewable energy projects in urban settings and no projects were found that included methodologies to allow for their assessment.

\section{REFERENCES}

Sánchez-Pantoja, N., Vidal, R., Pastor, M.C., 2018a. Aesthetic impact of solar energy systems. Renew. Sustain. Energy Rev. 98, 227-238. https://doi.org/10/gfqh7s

Sánchez-Pantoja, N., Vidal, R., Pastor, M.C., 2018b. Aesthetic perception of photovoltaic integration within new proposals for ecological architecture. Sustain. Cities Soc. 39, 203-214. https://doi.org/10/gdr37n 


\section{APÉNDICE}

AUTORIZACIÓN DE LAS COAUTORAS DE LOS ARTÍCULOS INCLUIDOS EN ESTA TESIS DOCTORAL 


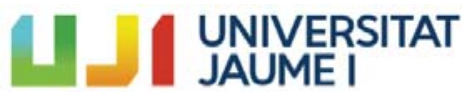

\section{Escola de Doctorat · ED}

Rosario Vidal Nadal, como coautora doy mi autorización a Núria Sánchez-Pantoja Belenguer para la presentación de las siguientes publicaciones como parte de su tesis doctoral.

Relación de publicaciones:

1. Núria Sánchez-Pantoja, Rosario Vidal, M. Carmen Pastor. Aesthetic Impact of Solar Energy Systems. Renewable and Sustainable Energy Reviews, 2018, 98, 227-238. DOI: 10.1016/j.rser.2018.09.021

2. Núria Sánchez-Pantoja, Rosario Vidal, M. Carmen Pastor. Aesthetic Perception of Photovoltaic Integration within new Proposals for Ecological Architecture. Sustainable Cities and Society, 2018, 39, 203-214. DOI: 10.1016/J.SCS.2018.02.027

3. Núria Sánchez-Pantoja, Rosario Vidal, M. Carmen Pastor. Aesthetic Perception of the Urban Deployment of Renewable Energies in European-funded Projects. Pendiente de aceptación para publicación en la revista científica Renewable and Sustainable Energy Reviews.

Asimismo, renuncio a poder utilizar estas publicaciones como parte de otra tesis doctoral.

Y para que conste firmo el presente documento,

Firmado por MARIA ROSARIO VIDAL NADAL - NIF:21652812Z el día 14/09/2020

con un certificado emitido por ACCVCA-120

Castelló de la Plana, 14 de septiembre de 2020.

Todo ello, atendiendo al artículo 23 de la Normativa de los Estudios de Doctorado, regulados por el RD 99/2011, en la Universitat Jaume I (Aprobada por el Consejo de Gobierno núm. 19 de 26 de Enero de 2012, modificada por el Consejo de Gobierno núm. 29 de 27 de Noviembre de 2012 y con posterior modificación por el Consejo de Gobierno núm. 37 de 25 de Julio de 2013):

$$
\text { “(...) }
$$

"Aquellas tesis doctorales que opten por la incorporación de artículos (compendio de publicaciones) deben de ajustarse, en la medida de lo posible, a la siguiente estructura: -Introducción/objetivos - Un capítulo por artículo incorporado - Discusión general de los resultados - Conclusiones. -Aceptación de los coautores de que el doctorando presente el trabajo como tesis y renuncia expresa de estos a presentarlo como parte de otra tesis doctoral." 
Escola de Doctorat · ED

M. Carmen Pastor Verchili, como coautora doy mi autorización a Núria Sánchez-Pantoja Belenguer para la presentación de las siguientes publicaciones como parte de su tesis doctoral.

Relación de publicaciones:

1. Núria Sánchez-Pantoja, Rosario Vidal, M. Carmen Pastor. Aesthetic Impact of Solar Energy Systems. Renewable and Sustainable Energy Reviews, 2018, 98, 227-238. DOI: 10.1016/j.rser.2018.09.021

2. Núria Sánchez-Pantoja, Rosario Vidal, M. Carmen Pastor. Aesthetic Perception of Photovoltaic Integration within new Proposals for Ecological Architecture. Sustainable Cities and Society, 2018, 39, 203-214. DOI: 10.1016/J.SCS.2018.02.027

3. Núria Sánchez-Pantoja, Rosario Vidal, M. Carmen Pastor. Aesthetic Perception of the Urban Deployment of Renewable Energies in European-funded Projects. Pendiente de aceptación para publicación en la revista científica Renewable and Sustainable Energy Reviews.

Asimismo, renuncio a poder utilizar estas publicaciones como parte de otra tesis doctoral.

Y para que conste firmo el presente documento,

$$
\begin{array}{ll}
\text { MARIA DEL } & \text { Firmado } \\
\text { digitalmente por } \\
\text { CARMEN| } & \text { MARIA DEL } \\
\text { PASTOR| } & \text { CARMEN|PASTOR| } \\
\text { VERCHILI } \\
\text { VERCHILI } & \text { Fecha: } 2020.09 .14 \\
& 15: 52: 47+02^{\prime} 00^{\prime}
\end{array}
$$

Castelló de la Plana, 14 de septiembre de 2020.

Todo ello, atendiendo al artículo 23 de la Normativa de los Estudios de Doctorado, regulados por el RD 99/2011, en la Universitat Jaume I (A probada por el Consejo de Gobierno núm. 19 de 26 de Enero de 2012, modificada por el Consejo de Gobierno núm. 29 de 27 de Noviembre de 2012 y con posterior modificación por el Consejo de Gobierno núm. 37 de 25 de Julio de 2013):

$$
\text { "(...) }
$$

"Aquellas tesis doctorales que opten por la incorporación de artículos (compendio de publicaciones) deben de ajustarse, en la medida de lo posible, a la siguiente estructura: -Introducción/objetivos - Un capítulo por artículo incorporado - Discusión general de los resultados - Conclusiones. -Aceptación de los coautores de que el doctorando presente el trabajo como tesis y renuncia expresa de estos a presentarlo como parte de otra tesis doctoral.", 
